N

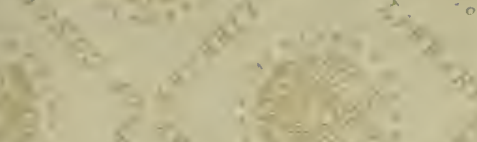

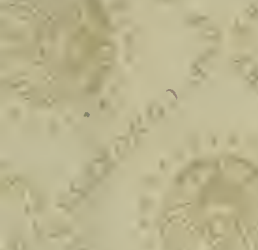

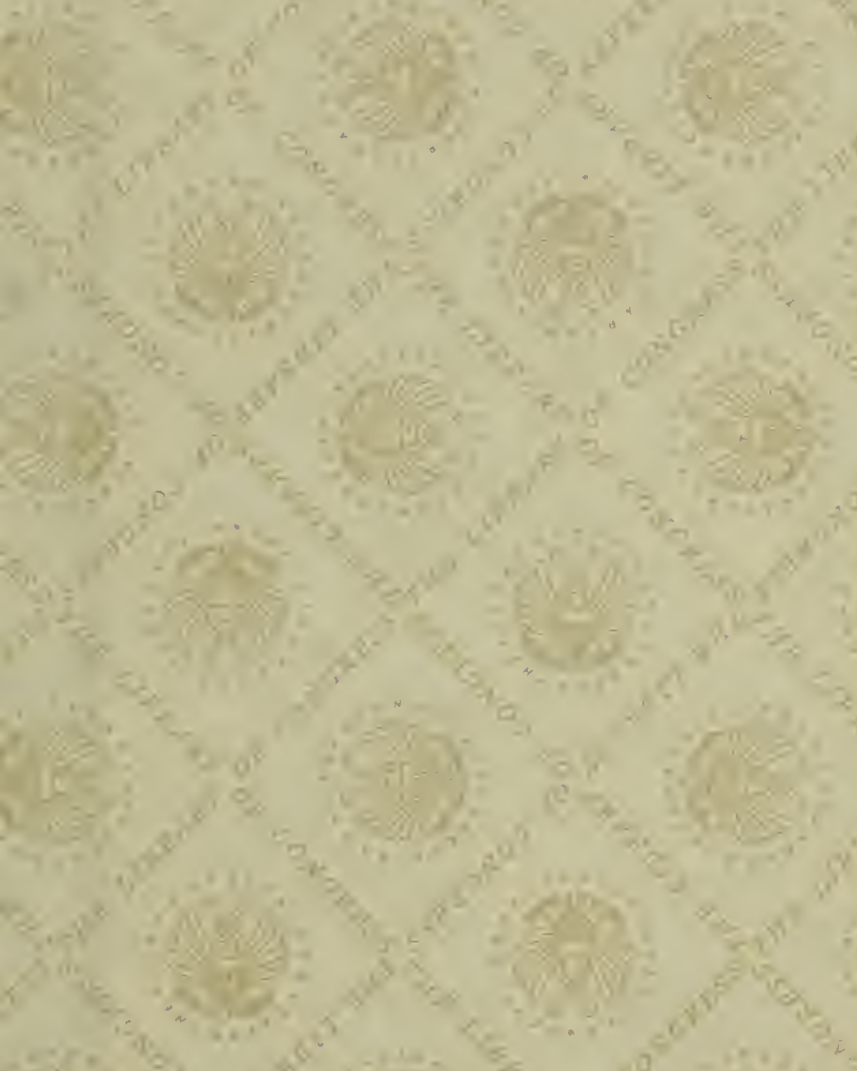




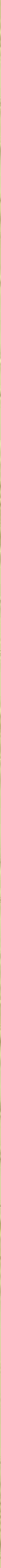







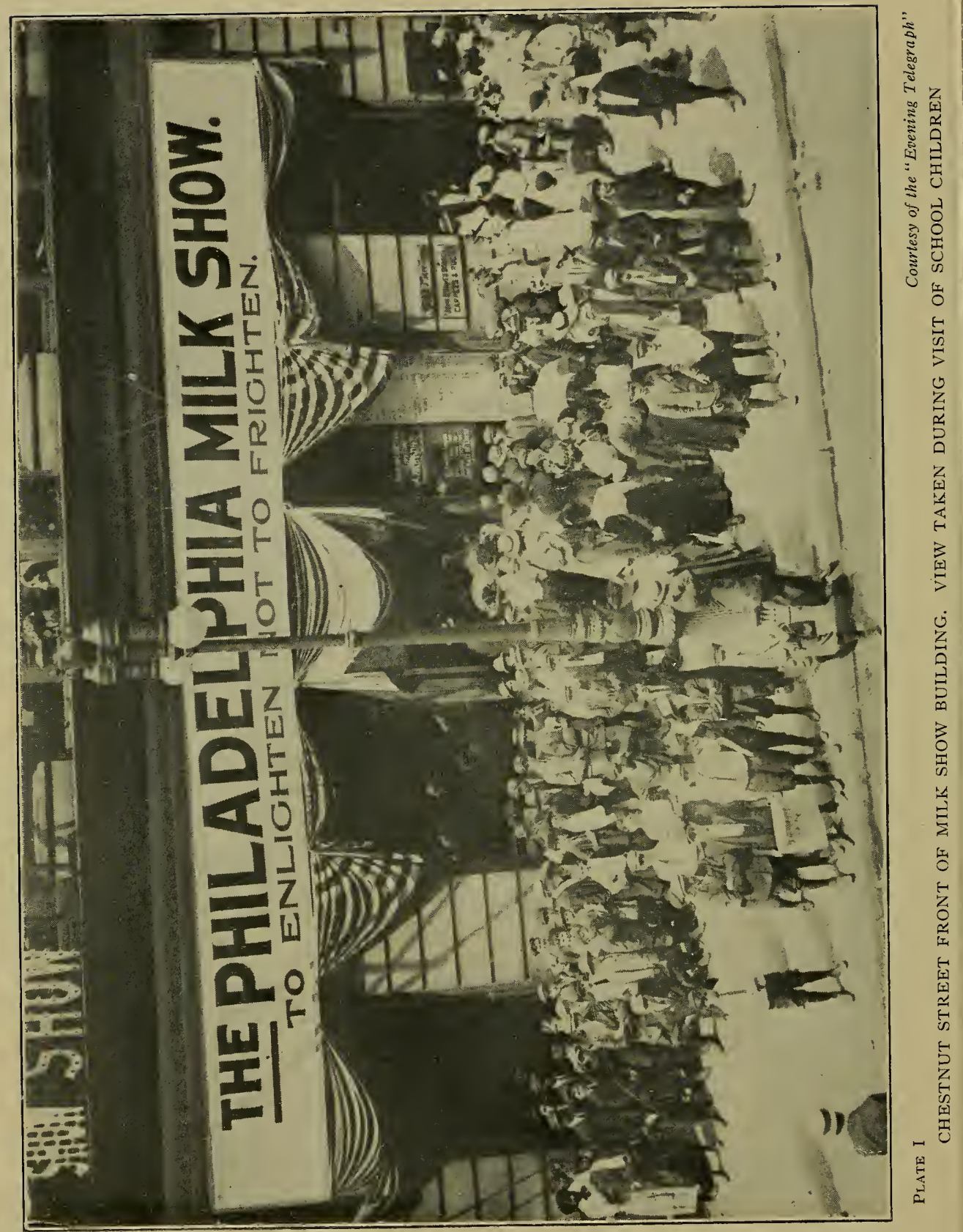




\title{
THE REPORT OF THE
}

\section{PHILADELPHIA MILK SHOW}

ITS ORGANIZATION AND MANAGEMENT

AND A DESCRIPTION OF THE EXHIBITS

\author{
EDIted BY
}

\section{ARTHUR EDWIN POST \\ Bureau of Municipal Research \\ Executive Secretary, Philadelphia Milk Show}

\section{Illustrated}

PUBLISHED BY THE

EXECUTIVE COMMITTEE

1911 
$b^{\infty} R^{\prime}$
$S^{2}$

Gift

Publishera

OCT $3181 \%$

$\therefore \vdots \vdots$ 


\section{PREFACE}

The main purpose of this report is to give as clear an idea as possible of the organization which devised and managed the recent Milk Show, to explain the methods employed, and to describe the exhibits.

The development of the Millk Show is a recent idea and the furtherance of it has already added materially to the educational propaganda of those communities fortunate enough to have held such exhibitions. In order, therefore, that a permanent record might be preserved of this interesting departure from the customary program of social work, and as a help and stimulant to others to direct their efforts along the same lines, the executive committee requested the writer to compile this report.

At the outset of this educational movement, practically no one knew what was meant by a Milk Show. The value of an exhibition which would tend to educate the community to the need of a safe milk supply was self-evident, but the exact procedure to be followed in preparing such an exhibition was unknown. Most of the resulting labor was therefore creative.

Looking to the economy of effort, it is hoped that this report may save to future promoters of similar undertakings the necessity of having to pass through the same stage of experimentation in the solving of many of the petty, yet important, problems which had to be determined by our organization. Within the limits of this report it is impossible to mention in full all the details incident to the work of organizing and managing such an exhibition, but it has been thought advisable to refer to as many of the details as possible. Effort has been made to treat the various parts as briefly as is commensurate with the magnitude of the task.

The writer wishes to take this formal and public means of thanking sincerely all those who have so considerably helped in the preparation of this report.

Through the coöperation of the Russell Sage Foundation of New York City, Dr. Hastings H. Hart, Director Department of Child Helping, was instrumental in having a catalogue compiled of the exhibits. This work was done by Miss Georgia G. Ralph and, by permission, her careful record is frequently quoted verbatim in the chapter devoted to the description of the exhibits.

Special thanks are due to Dr. Joseph S. Neff, Dr. Charles J. Hatfield, Dr. Joseph Walsh, and Dr. Samuel McC. Hamill for many valuable suggestions and helpful advice. The complete and accurate minutes of the executive committee have been of great assistance; and the carefully compiled inventory records and descriptions of certain of the exhibits, prepared by Dr. C. J. Marshall, Dr. J. Claxton Gittings, Dr. Frank A. Craig, Dr. S. W. Newmayer, Dr. Bertha Lewis, and Mr. David C. Clegg have been freely used.

Neither a comprehensive record of the procedure followed by the various committees, nor a complete description of the exhibits could have been attempted in this report but for the kindly assistance of these many collaborators.

A. E. P. 



\section{CONTENTS}

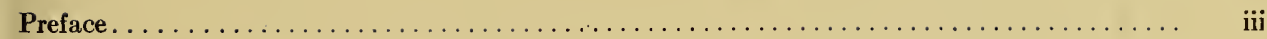

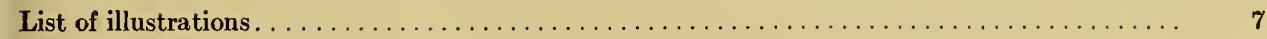

\section{PART I.-INTRODUCTORY STATEMEN'T}

Initial meeting: function and scope of a milk show.

\section{PAR'T II.-SUMMARIZATION OF WORK OF COMMITTEES}

Executive, including office of executive secretary $\ldots \ldots \ldots \ldots \ldots \ldots \ldots \ldots \ldots \ldots \ldots \ldots \ldots$

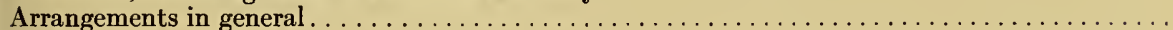

Finance.

Publicity

Procuring exhibits.

Lectures and demonstrations.

Conference of health officers

Education.

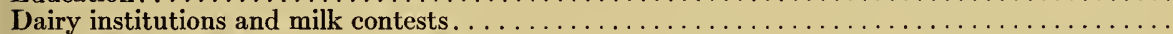

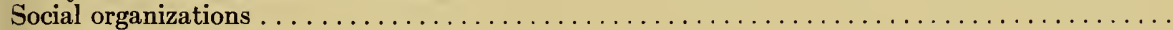

Patronesses and aides.

\section{PART III.-GENERAL DESCRIPTION}

Milk Show .

Conference of State and Municipal Health Officers . . . $\ldots \ldots \ldots \ldots \ldots \ldots \ldots \ldots \ldots \ldots \ldots \ldots$

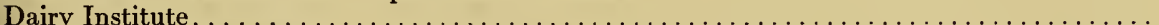

Milk and cream contests.

\section{PART IV.-DETAILED DESCRIPTION OF EXHIBITS}

Educational exhibits

\section{APPENDICES}

A. Program of Milk Show. ...........

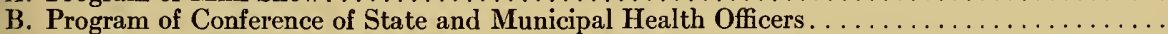

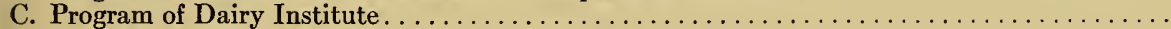

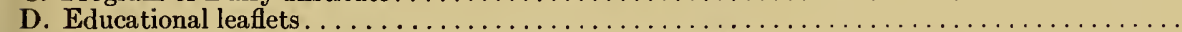

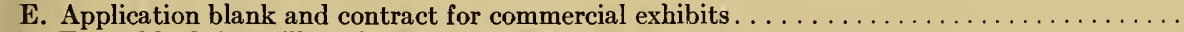

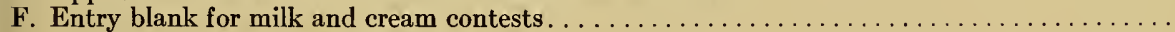

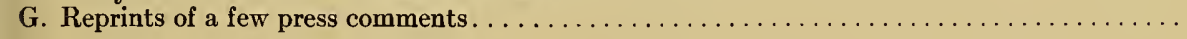

Index 



\section{LIST OF ILLUSTRATIONS}

I. Chestnut Street front of Milk Show building. View taken during visit of school

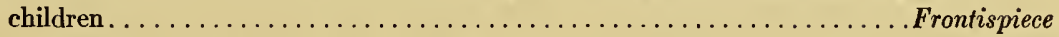

II. Some of the required stationery and printing. $\ldots \ldots \ldots \ldots \ldots \ldots \ldots \ldots \ldots, 16$

III. Colored advertising card displayed in store windows and subway, elevated, and sub-

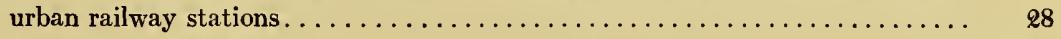

IV. Colored advertising card displayed within city street cars............... 30

V. A few headlines, showing the way the newspapers helped ............... 32

VI. Little mothers from city schools visiting the Show. They formed in double line after

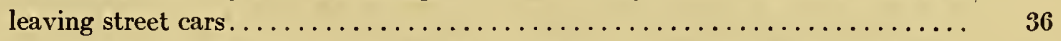

VII. Educational placard distributed to visitors: furnished by Russell Sage Foundation. . $\quad 38$

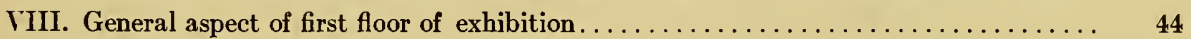

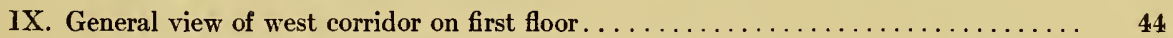

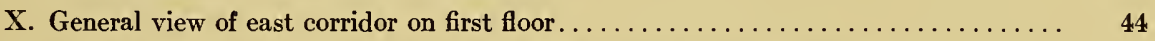

XI. Engraved invitation to private view, held day before public opening......... 44

XII. Chart showing distribution of attendance. More demonstrators and attendants re-

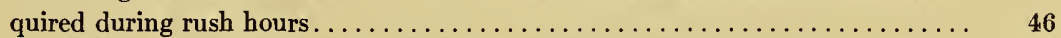

XIII. Diploma embossed with city seal awarded in milk and cream contests........ 48

XIV. Floor plan of exhibition showing sections, entrances, exits, elevators, etc........ $\quad 52$

$\mathrm{XV}$. Window charts giving infant mortality statistics with red electric light flashing to

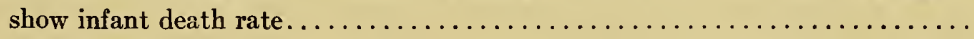

XVI. Left half of section 1. Apparatus used in making physical and chemical tests of milk. Charts illustrating different kinds of organisms found in milk............

XVII. Right half of section 1. Apparatus used in making laboratory tests of milk. Charts illustrating different organisms found in milk, and studies of disease epidemics traced to infected milk. . . . . . . . . . . . . . . . . . . . . . . . . . . .

XVIII. Section 3. Photographs of dairy farms producing certified milk sold in Philadelphia. Charts showing results of bacteriological examination of certified milk, and fre-

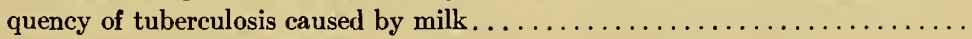

XIX. Section 4. Photographs of existing conditions of Philadelphia's milk supply...... $\quad 56$

XX. Section 5. Certified milk from a local dairy ..................... $\quad 56$

XXI. Section 6. Model of an excellent type of dairy barn. Modern sanitary milk can and

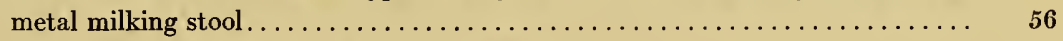

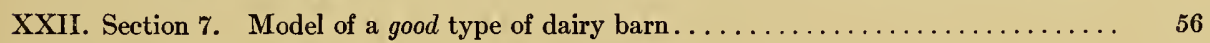

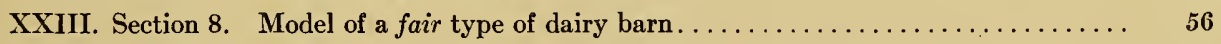

XXIV. Section 9. Model of a bad type of dairy barn..................... $\quad 56$

XXV. Section 11. Charts showing proposed record form for use of city milk inspectors; necessity for constant inspection from cow to consumer; and full and short measure bottles. Map shows sources of Philadelphia milk supply..........

XXVI. Section 12. Photographs of refrigeration service furnished for transportation of milk and model of improved type of cattle car....................... 
XXVII. Section 13. Photographs of conditions found on dairy farms, cars, receiving stations, wagons, and stores. Models show relative amounts of different grades of milk

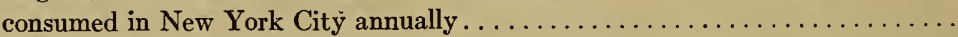

XXVIII. Section 14. Display of economical refrigerators, fireless cookers, and a contrasting collection of good and bad milk utensils. Charts giving instructions to mothers, tables of food values, formulas for modification of milk, etc.............

XXIX. Section 15. Model kitchen, containing inexpensive, sanitary equipment, used in practical demonstrations of the uses of milk.......................

XXX. Section 16. Results of bacteriological examination of samples of ice cream, and machine for sanitary manufacture of ice cream.........................

XXXI. Section 17. Complete apparatus used in scientific pasteurization of milk.........

XXXII. Section 18. One-third of exhibit on child hygiene. Photographs and placards showing proper care of babies in home and hospital.......................

XXXIII. Section 19. One-third of exhibit on child hygiene. Photographs, paintings, and charts showing proper care of babies, and instructions for mothers...........

XXXIV. Section 20. One-third of exhibit on child hygiene. Photographs, charts, and models showing proper care of babies, and statistics on infant mortality ...........

XXXV. Section 21. Record forms and apparatus used by various cities in taking of milk samples for laboratory analyses. Sanitary milk can.................

XXXVI. Section 22. Prize cups awarded in milk and cream contests. Photographs of model

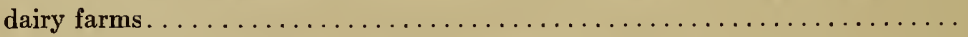

XXXVII. Section 23. Photographs showing care of babies in hospital, with equipment, methods, and report forms used. Models of milkers and photographs of plant and methods of model dairy farm . . . . . . . . . . . . . . . . . . . . . . . . .

XXXVIII. Section 24. Photographs showing equipment and methods of dairy farms producing certified milk. Charts showing purpose, growth, and results of medical milk commissions. Milk utensils used in shipping and modification of milk.......

XXXIX. Section 25. Methods and results of chemical tests to detect disease in cattle. Specimens, photographs, and charts showing diseased parts................

XL. Section 25. Charts showing most approved types of milk pails, and results of bacteriological studies of use of various kinds of utensils and processes in milk production . . . . . . . . . . . . . . . . . . . . . . . . . . . . . . . . . . .

XLI. Left half of section 26. Contrasting photographs showing good and bad conditions of stables, dairy cattle, milk houses, handling of milk, etc...............

XLII. Right half of section 26. Contrasting photographs showing good and bad conditions of city milk plants, milk distribution, care of milk in the home, food value of milk, and results of score card inspection system....................

XLIII. Section 27. Photographs illustrating foreign and domestic farms, and conditions of distribution and sale. Model of sanitary dairy barn................

\section{ILLUSTRATIONS IN TEXT:}

Small advertising cards distributed to school children . . . . . . . . . . . . . . . . . . . . .

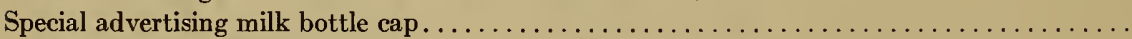

Assignment chart used by committee on patronesses and aides....................

Educational leaflets:

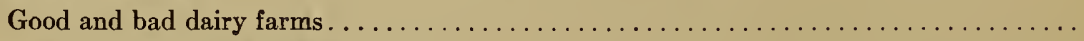

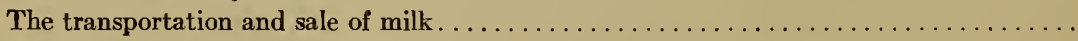

Care of the milk in the home... 
The food value of milk. .

Diseases caused by impure milk

Suggestions for bottle-fed babies.

Milk "Don'ts"

Refreshing milk drinks

A milk primer 

PART ONE

\section{Introductory Statement}





\section{PART ONE}

\section{Introductory Statement}

\section{Initial Meeting: Function and Scope of a Milk Show}

On April 13, 1911, a meeting was called by Dr. Joseph S. Neff, Director of the Philadelphia Department of Public Health and Charities, for the purpose of considering the advisability of holding a Milk Show during the third week in May when two national organizations were scheduled to hold their annual meetings in this city.

Because of the fact that for several months the milk problem had been receiving the close attention of municipal health authorities, public press, medical profession, and citizens generally, it was the consensus of opinion at this meeting that a free exhibition which would serve to bring out clearly all of the various phases of the milk question would be of great educational benefit to the community. After considerable discussion as to the method of financing such an undertaking, it was finally deemed feasible of accomplishment, and the persons in attendance were constituted an executive committee to perfect a permanent organization and proceed with active preparations for the Show.

The general scope of the proposed exhibit was clearly stated in a small folder, entitled "Preliminary Announcement," reading as follows:

There exists at the present time, throughout the entire country, a thorough appreciation of the close relationship between the milk supply of municipalities and the life and health of its citizens. The Mayor of the City of Philadelphia, and the Department of Public Health and Charities, realizing the importance of this relationship, recently appointed a commission to study and report upon the conditions of production, transportation and distribution of milk as they exist in Philadelphia, and to suggest measures by which the objectionable features of these processes might be eliminated. The report of this commission has been submitted and published.

During the fourth week of May, the annual sessions of two national organizations, The American Association of Medical Milk Commissions, and the Certified Milk Producers' Association of America-both interested exclusively in the problem of improving the milk supply of the country-will be held in Philadelphia.

It is proposed as a fitting sequel to the work of the Milk Commission of Philadelphia, and on account of the interest which it has stimulated, to supplement the meetings of these national associations by a milk exhibition, to be opened on the 20 th of May, and to continue until the 27th. This exhibition will be patterned after the very successful tuberculosis exhibits which have been held in this city, and will have exactly similar purposes, namely, the education of the public. Much good also can be done in an educational line toward bringing the varied interests of the milk trade into harmonious action. The exhibition will especially emphasize the value of milk as a food, the influence of a bad milk supply upon the life and health of the community, and the agencies and methods by which such influences can be overcome. Public educational lectures on subjects relating to milk will be delivered daily throughout the week.

In order that this subject may be fully considered from every viewpoint, and for the benefit of Philadelphia in particular, a Dairy Institute for the education of those who pro- 
duce and deliver milk, and a Conference of Health Officers of the various cities of the United States and Canada will be held during the same week.

The Dairy Institute will be held in the Veterinary Building of the University of Pennsylvania on May 24th, 25th and 26th. Addresses will be made on the feeding, breeding, and selecting of dairy cows; sanitary milk; production and distribution of milk in cities, etc., by men with a special knowledge of these subjects. The sessions will begin each day at $10 \mathrm{~A}$. M, and continue until $1 \mathrm{P} . \mathrm{M}$. The Conference of Health Officers will be held on Thursday, May 25th.

The importance of this whole subject relating to a safe milk supply cannot be overestimated, primarily for the city of Philadelphia, and secondarily for the country at large.

Capable demonstrators will be provided to explain the educational exhibits.

Lectures and moving pictures will be given at 12.20 o'clock noon; 3 P. M. and 8 P. M. in the lecture room.

The Show will be open every day from May 20 th to 27 th (inclusive) from $10 \mathrm{~A} . \mathrm{M}$. until 10 P. M., with the exception of Sunday, when the hours will be from 1 P. M. until 10 P. M. Admission to all the exhibits and all the lectures will be free.

In addition to the foregoing extract, the preliminary announcement contained a schedule of the proposed classes of exhibits (see p. 33), a tentative program of lectures and speakers, a list of the officers, and a statement that the Milk Show was under the auspices of-

Department of Public Health and Charities,

Milk Commission of the Philadelphia Pediatric Society,

Veterinary Department of the University of Pennsylvania,

Bureau of Municipal Research of Philadelphia, And many other coöperating agencies.

Since the real work in a movement of this kind must be done by subcommittees, the complete story of the organization and management of the Show can best be given by summarizing the work of each committee, which follows in the next part. 
PART TWO

Summarization of Work of Committees 




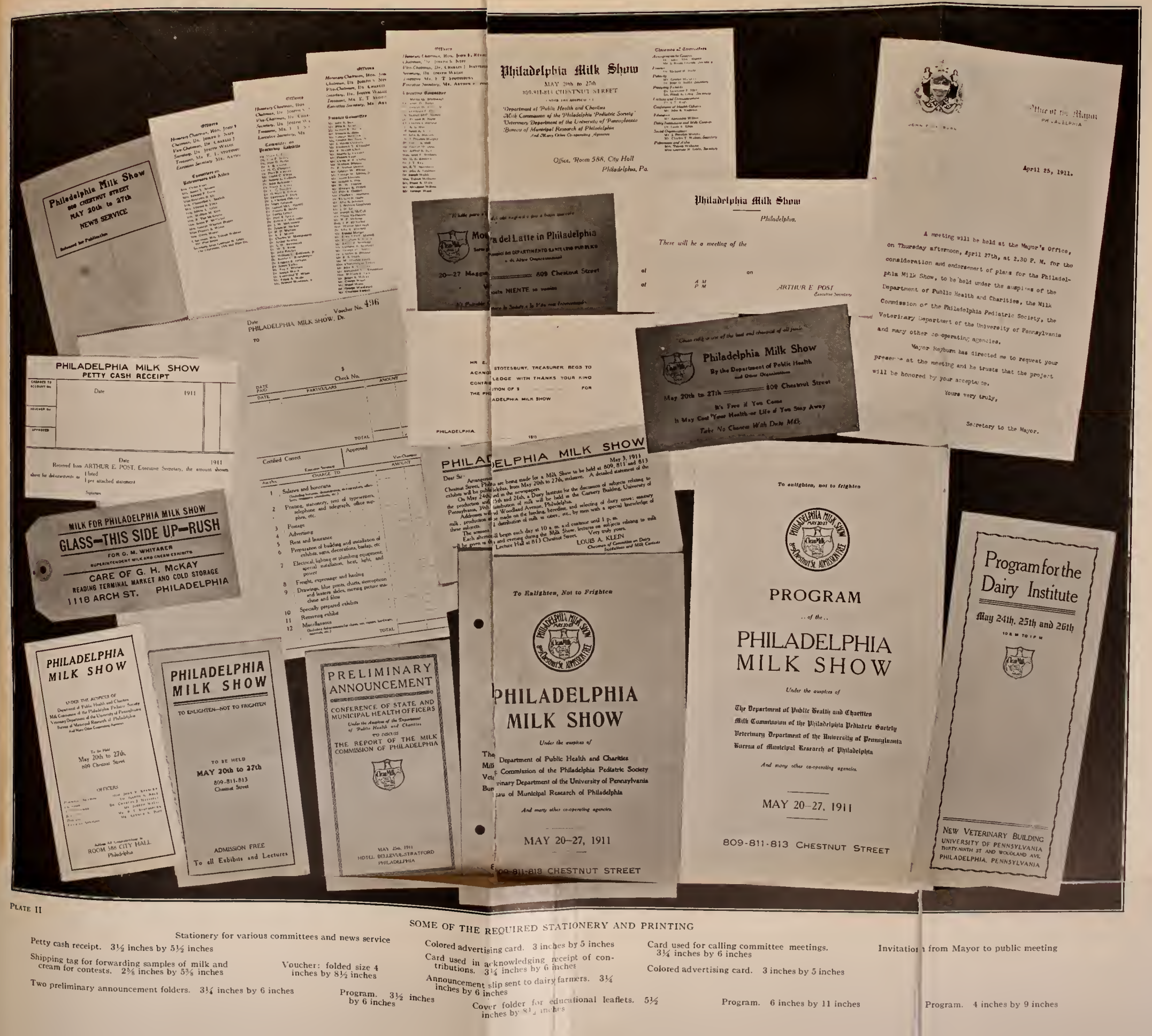





\title{
PART TWO
}

\section{Summarization of Work of Committees}

\section{Executive Committee, Including the Office of the Executive Secretary}

\section{OFFICERS}

\author{
Hon. John E. ReYburn, Honorary Chairman \\ Dr. Joseph S. NeFF, Chairman \\ Dr. Charles J. Hatfield, Vice-chairman \\ Dr. Joseph WALSH, Secretary \\ Mr. E. T. StotesbuRY, Treasurer \\ Mr. ARTHUR E. Post, Executive Secretary
}

\section{EXECUTIVE COMMITTEE}

\author{
Dr. Martin G. Brumbaugh \\ Dr. Jesse D. Burks \\ Mr. George W. Elrins, Jr. \\ Dr. LaWrence F. Flick \\ Dr. SaMuel MCC. HaMill \\ Dr. Richard H. HaRte \\ Dr. Charles J. Hatfield \\ Mr. A. B. HueY \\ DR. Louis A. KLeiN \\ Dr. John K. Mitchell \\ Mr. J. Prentice Murphy \\ Dr. Joseph S. NefF
}

Mr. Grorge W. Ochs

Mr. Arthur E. Post

Hon. John E. Reyburn

Mr. H. P. RhoAdes

DR. J. T. RUGH

Mr. E. T. Stotesbury

Mr. John A. Vogleson

Dr. JosepH WALsh

Mrs. Talcott Williams

Mr. Frank A. Wills

Mr. Alexander M. Wilson

Mr. George Wood

Beginning with the initial meeting on April 13th, this committee held regular meetings on each Monday and Thursday until the close of the Show in the office of the Director of the Department of Public Health and Charities.

At the first meeting, officers were elected as given above and the presiding officials of each of the various milk producers' and dealers' associations in the city were elected to membership on this committee as representing their respective associations.

Thus augmented, the executive committee immediately proceeded to business by appointing the chairmen of all subcommittees who in turn selected the members of their committees. All appointments to committees were reported to this committee for formal ratification, and official announcements were sent to all appointees notifying them of their selection.

Through the courtesy of Mr. W. D. Champlin of the Public Playgrounds Committee, the executive secretary was permitted to occupy quarters in their committee room in City Hall where the business of the Milk Show could be transacted. A stenographer and office boy were immediately employed, a typewriter and neces- 
sary furniture rented, and general supplies and stationery purchased. This force was later increased by the addition of four other stenographers, one of whom devoted most of her time to the work of preparing copy for the newspapers. The office was opened April 17th, and closed August 12th.

A contract was made with a press clipping bureau to supply all news articles on the Milk Show, and a scrap book was started in which the clippings and samples of all stationery and printed matter were preserved for reference.

For the purpose of interesting individuals and organizations in the Show, a preliminary announcement folder was prepared and an edition of 13,000 copies printed. The contents of this folder have been referred to on p. 13 .

After the work of the subcommittees and the office of the executive secretary had been duly organized and started, the duties of the executive committee were chiefly of an advisory nature in supervising the operations of the subcommittees and the executive secretary. At all meetings of this committee, detailed reports were rendered by the chairmen of committees and the executive secretary, these reports being incorporated in the minutes. Typewritten copies of the minutes were mailed to all the members of the committee immediately following each meeting, and absent members were thereby kept currently informed of the transactions.

Regarding the exact character which the exhibit was to assume, it was decided that the exhibits should be divided into two parts; namely, educational and commercial. The educational exhibits were to consist of all those which in any way served to portray conditions relative to the care of cows, the process of milking and handling milk on the farm, transportation and distribution of milk, and its uses as a food; the commercial exhibits were to include all the exhibits submitted by any individual or company dealing in milk or milk utensils for commercial profit.

As to the suggestion of combining with the Milk Show an exhibit of playgrounds, school gardens, etc., it was decided that because of the limited space available the exhibition should be confined strictly to milk products, utensils and processes.

The question arose as to the possibility of placing too great emphasis upon dirty conditions, especially on conditions which no longer exist. One of the representatives of the milk associations stated that if too great emphasis were placed on milk contamination, the resulting tendency would be to prevent people from drinking milk, which was by no means the object of the Show. The consensus of opinion on this point was that it was necessary to show conditions as they actually existed but that too great stress should not be placed on bad conditions.

As a means of working up enthusiasm for the Show, this committee made arrangements for a public meeting to be held in the Mayor's office on the afternoon of April 27th. About eight hundred invitations were issued by the Mayor to members of City Councils, representatives of the various city departments, hospitals, dispensaries, relief societies, day nurseries, visiting nurse societies, and organizations concerned with summer care for mothers and babies. This meeting was fairly well attended, and much enthusiasm was manifested by those present. Dr. Joseph S. Neff, Director of the Department of Public Health and Charities, presided and summarized the steps that had been taken toward bettering the city's milk supply. Other addresses were made on the purposes of the Show and its educational value to the community by Dr. Samuel McC. Hamill, Dr. Jesse D. Burks, Mrs. Owen Wister and Dr. Talcott Williams. 
One of the most important matters to be dealt with at the start was that concerning the estimated expenses and the manner of financing the Show. To make such an estimate the chairmen of subcommittees were requested to submit as soon as possible to this committee statements of the estimated expenditures of their committees. With this information in hand, the finance committee was able to make definite plans for financing the undertaking. For further details, see p. 24 .

The question was raised as to whether or not it was advisable to employ an advertising solicitor who would issue on a commercial basis a program of the Show containing advertisements. After much discussion in which it was shown that it was most difficult to properly censor and control the advertising solicited in such a manner, it was decided that such a program should not be issued.

The suggestion was made that a notice of the Milk Show might be sent to the various dairy farmers producing milk for this city by the introduction of a folder or announcement slip into the monthly payment letters which are sent to the farmers by the city dealers. Such an announcement containing a notice of the Dairy Institute was prepared, being printed just large enough to slip into a number five envelope. Next, a list of the various city dealers together with the number of dairy farmers supplying each was procured from the Chief Inspector of Milk. A letter was then sent to all city dealers requesting them to include one of these announcement slips with each of their remittance letters to the various farmers, and included with this letter were the requisite number of announcement slips.

At the request of the Civic Club, it was decided that, wherever convenient, the "Kill that fly" stamp should be used on all correspondence as a means of helping along the campaign against the house fly.

Concerning the question of insurance for show rooms and the exhibits, after consideration as to whether or not the Milk Show should insure the commercial exhibits against fire as well as the educational exhibits, it was decided that only the educational exhibits should be covered by fire insurance policies.

It was decided to display prominently the legend "To Enlighten-Not To Frighten" on the program of the Show and on the sign on the front of the exhibition building.

Since the scheme for financing the Show, as outlined on p. 24, called for a final settlement by the guarantors after the completion of the Show, it was necessary to provide some means by which current running expenses might be met. Through the kindness of Mr. E. T. Stotesbury, the Milk Show was enabled to draw upon Drexel \& Company for current expenses, with the understanding that the final adjustment was not to be made until after the Show, when the guarantors would be called upon to pay any deficit. A form of voucher was prepared by the executive committee which provided for the payment of all bills of five dollars and over. Bills under five dollars were paid from a petty cash fund by the executive secretary. This form of voucher had to be approved and countersigned by the executive secretary and the vice-chairman before payment could be made by the treasurer. When so certified, a check was mailed by the treasurer to the creditor. These vouchers were printed in duplicate and numbered consecutively in red. The original copy was sent to the treasurer with all bills folded and attached inside the voucher; the duplicate was retained in the office of the executive secretary for reference. (For reproduction of this voucher form, see plate facing p. 16.) 
Regarding the payment of all bills, it was decided that,

First, all bills must be approved by the person incurring the indebtedness;

Second, forwarded by such person to the chairman of his committee, who would further approve; and,

Third, forwarded by the chairman to the executive secretary, who would make out a voucher on the treasurer for the expenditure or would pay the same from the petty cash fund.

In order to meet the current running expenses incident to the office of the executive secretary, a petty cash account of one hundred dollars was established. All payments from this fund were receipted for upon a special form of petty cash receipt. See reproduction in plate facing $p .16$.

Owing to the fact that it was much more convenient both in the office of the executive secretary and to the treasurer, the salaries of the office force were paid from the petty cash fund. With this exception, no bills calling for more than five dollars were paid from petty cash.

When it was necessary to replenish the petty cash fund, a voucher accompanied by the receipts for payments made was turned in to the treasurer with a statement of the amount of cash on hand. Thereupon the treasurer would receive the petty cash receipts in exchange for an equal amount of cash, making the complete petty cash account of the executive secretary an even one hundred dollars.

During the period of the show it was necessary to establish a second petty cash account for use at the exhibition rooms in paying current expenses. This fund, amounting to twenty-five dollars, was paid from the petty cash account of the executive secretary and was receipted for by the secretary of the committee on arrangements in general. The manner of administering this account by the secretary of the committee on arrangements in general was exactly the same as followed with the petty cash account of the executive secretary, petty cash receipts being taken for all payments, which receipts were redeemable in cash.

The payrolls for the various attendants and laborers at the exhibition rooms were compiled and the employees paid in cash at the end of each week. The amounts called for by these payrolls were not paid from petty cash, but a payroll was prepared in advance and a voucher in favor of the executive secretary was drawn on the treasurer accordingly. The treasurer thereupon advanced the required amount to the executive treasurer, who in turn gave a receipt for the amount so advanced. Next, the cash received was put up in accordance with the payroll in individual envelopes, each containing a petty cash receipt for the amount enclosed. Payroll disbursements were made by the executive secretary, who exacted signed and dated receipts for every payment. Later these receipts were delivered to the treasurer, who attached the same to the voucher which had previously been drawn to cover the expenditure.

In anticipation of the publication of a comprehensive report, the chairmen of committees were requested by this committee to furnish the executive secretary with detailed inventories of their exhibits, and after the exhibits were installed, a photographer was employed to take photographs of the various booths. 
After the close of the exhibit, there remained certain miscellaneous articles, such as floor mats, rolls of oilcloth, galvanized-iron buckets, waste-paper baskets, and a few pieces of furniture, all of which were presented to the White Haven Sanatorium. A limited quantity of some of the educational leaflets remained and they were given to the Bureau of Health.

Before the Milk Show organization disbanded, the attempt was made to acknowledge all assistance and coöperation which had been given by numerous individuals, organizations, and firms. In many cases, such acknowledgments were made personally by the members of the committees; in other cases, letters were mailed by the executive secretary.

A large amount of detailed, clerical, and stenographic service was performed by the office of the executive secretary. Throughout the course of the work, both before and after the Show, it was necessary for practically all the officers and committee chairmen to call upon the office at some time to attend to countless details. In addition, much work was performed in the personal offices of members of the organization. Besides the care of the regular correspondence in the office of the executive secretary (which necessitated the writing of over one thousand letters), it was necessary to compile several mailing lists, address thousands of envelopes, make numerous lists of committees, prepare payrolls, send out notices of committee meetings, deliver supplies of stationery to various committees, refer daily mail to proper committees, arrange for the distribution and delivery of preliminary announcement folders and advertising cards, and other tasks, such as the counting and folding of the entry blanks for the milk contest, requiring a large amount of actual labor and careful system.

The last meeting of the executive committee was held on June 1st. Much unfinished business remained to be transacted. Many bills were outstanding and the final accounting remained to be made. It was desired that no further meetings of this committee should be held, and it was therefore decided that the authority for the transaction of all unfinished business should be vested in the officers of the executive committee. Two meetings of the officers were necessary to close up the business.

\title{
Committee on Arrangements in General
}

\author{
Dr. Samuel McC. Hamill, Chairman \\ Mr. J. Byron Deacon, Secretary \\ Dr. Howard Carpenter \\ Dr. A. P. Francine \\ Dr. John Crutce \\ Dr. Charles J. Hatfield \\ Dr. Charles A. Fife \\ Dr. J. Clinton Foltz \\ Dr. Frederick Fraley \\ DR. H. D. JUMP \\ DR. W. D. RoBINSON \\ Dr. John F. Sinclatr \\ Dr. J. GURNeY TAYLOR
}

The first and most important duty of this committee was that of securing a suitable place to hold the exhibition. It was most desirable that the exhibition be held in a central location on some prominent street, easy of access, in rooms with good lighting and ventilation, with front and rear exits, adequate elevator service 
and fire protection, and rooms sufficiently large to permit of the installation of the exhibition on not more than two floors.

After carefully inspecting all the available properties in the central part of the city, the first two floors of the Dobson Building, at 809 and 811 Chestnut street, were selected and rented for the month of May at a rental of seven hundred and fifty dollars. This building, extending through from Chestnut street to Ludlow street, measured about forty-seven by one hundred and fifty feet, and provided approximately fourteen thousand one hundred square feet of floor space.

In order not to encroach on this floor space which was no more than enough for the various exhibits, a room to be used as a lecture hall was secured by renting the ground floor of the adjoining property at 813 Chestnut street. Through the kindness of the Commonwealth Title Insurance and Trust Company, the owner, a nominal rental of twenty-five dollars per week was paid for this property, measuring about twenty-five by one hundred and fifty feet, and therefore furnishing thirtyseven hundred and fifty additional square feet of floor space. This room was well lighted and ventilated, having formerly been used as a banking room, and had both front and rear exits, thus providing a safe lecture room in case of fire. A lecture platform with a screen for stereopticon and moving pictures was built in the rear.

Fire, accident and general liability insurance policies were taken out on both properties.

As the first step toward the preparation of these buildings for the show, detailed drawings were made of the exhibition rooms showing the proposed aisles, sections and counters, and the existing stairways, elevators, fire towers, windows, doors, and exits. Each section, or booth, was numbered as will be seen by reference to the reproduction of the floor plans opposite p. 52. This important work was done by Messrs. Brockie and Hastings, architects, who kindly contributed their valuable services and furnished the necessary blue prints for the various committees.

With these plans as a basis upon which to work, contracts were immediately entered into for the cleaning, decorating and altering of both premises. The contract with the cleaning company called for an initial cleaning and for daily cleaning throughout the period of the show. The decorating company was engaged to build all booths, covering same with dark green burlap; to prepare numerous oilcloth signs; to decorate both buildings (exterior and interior) with attractive columns, shields, bunting, flags, etc.; to remove certain partitions temporarily, same to be replaced after the show; and to build an additional outside exit stairway in the rear of the Dobson Building.

Other details attended to by this committee included the installation of electric lights and a large electric advertising sign on the front of the building; making arrangements for the provision of water, gas, and electricity as needed in different exhibition booths or sections; the equipment of the office at the show rooms with furniture, adding machine, typewriter, etc.; the inspection of the exhibition rooms and lecture hall by the city fire and building inspectors; and the provision of numerous electric fans, drinking fountains with sanitary cups (penny in the slot machines), several public telephones, chairs for the lecture hall, tables and other furniture for various booths, and numerous signs. Large signs had to be provided for each booth giving the name of the exhibitor and many small signs for use in connection with the exhibits. In addition, large conspicuous signs were prepared, such as: 
Not How Cheap Milk But How Good. We Do Not Want Cheap Milk at a Cheap Price. Pure Milk Is Bargain Enough.

You Can Get Good Milk If You Will Pay the Price. Bad Milk Is Expensive or Dangerous at Any Price.

When People Demand Good Milk They Will Get It. Do Not Leave It to the Health Authorities Entirely to Protect Your Children.

Do You Use Milk? If so, Keep It Clean-Covered-Cold.

Cleanliness and Cold Are the Two Essentials for Clean Milk.

Pure Milk for Sale. Consumer's Price.

Lecture to-day in Lecture Hall next door 12 M., 3 P. м. and 8 P. M. (Several.)

Do Not Fail to see Exhibits on Second Floor. Take Elevator or Stairway.

Visit the Exhibits on Second Floor, then Go Directly to Lecture Hall.

Exit at Rear. (Several.)

Positively No Smoking. (Several.)

Dates were set by this committee when exhibits were to be received and installed and all exhibitors were so notified. In order to expedite the work of unpacking and hanging the exhibits as received, which duty was to be performed by a subcommittee on installation, a superintendent (to have charge of the workmen) and the necessary carpenters and laborers were employed. The delivery of the exhibits to the exhibition rooms and the removal of the same after the Show were duties of the committee on procuring exhibits.

On the floor of each section or booth was chalked a number, corresponding with the plans prepared by the architects. It was therefore a simple matter for a member of the subcommittee on installation to receive all exhibits as delivered by the committee on procuring exhibits and distribute them directly to their respective sections, following the numbers on the plans. As each exhibit was unpacked, the box in which it had been shipped was marked with the exhibitor's name and also the number of the section in which its contents had been placed. The shipping boxes were then stored in the basement. The contents of each box was checked with the lists previously submitted by the exhibitor. (See committee on procuring exhibits, p. 34.) This plan was practically reversed at the conclusion of the Show when the exhibits were taken down and prepared for the return shipment.

This committee attended to the general management of affairs during the period of the Show, such as: arranging with the Department of Public Safety for details of policemen and firemen; providing guards and attendants about the premises and at all entrances and exits to keep the visitors moving in one direction only; supervising the sale of certified milk in order that the supply should not be exhausted; ordering additional quantities of the educational leaflets as needed; making necessary alterations in the installation of certain exhibits; supervising the services of the demonstrators and force of workmen; and overseeing the daily cleaning and condition of the Show rooms.

After the closing of the Show, this committee was responsible for the restoration of both buildings to the condition they were in when leased: to this end, repairs by plasterers and painters were made. 


\section{Finance Committee}

Mr. John E. BAIRd

Mr. Eluis A. Ballard

Mr. Samuel T. Bodine

Mr. Francis E. Bond

Mr. George Burnham, Jr.

Mr. William Burnham

Mr. J. Hayes Carstairs

Mr. Frederick T. Chandler

Mr. E. Walter Cllark

Mr. Morris L. Clothier

Mr. Francis Cope

Mr. Cyrus H. K. Curtis

Mr. Willitam Disston

Dr. R. Norton Downs

Mr. George W. ElKins

Mr. George W. EukINs, JR.

Mr. James Elverson

Mr. Samuel S. Fels

Mr. W. W. Frazier

Mr. Howard B. French

Mr. Eulis A. Gimbel.

Mr. Charles C. Harrison

Mr. Alba B. Johnson

Mr. J. Bertram Lippincott

Mr. J. D. LIT

\section{E, Chairman}

Mr. JosepH B. McCall

Mr. Frank McFadden

Mr. H. P. McKean

Hon. J. P. MeNichol

Hon. Wayne McVeagh

Dr. John K. Mitchell

Mr. Randal Morgan

Mr. Edward DeV. Morrell

Mr. Effingham B. Morris

Mr. Arthur E. Newbold

Mr. Clement B. Newbold

Mr. George W. Norris

Dr. Charles B. Penrose

Mr. E. B. SMITH

Mr. W. Hinckle Smith

Mr. E. T. STOTESBURY

Hon. Charlemagne Tower

Mr. John R. Valentine

Mr. Alexander Van Rensselaer

Hon. Willitam S. Vare

Mr. James B. Willcox

Mr. George Wood

Mr. Stuart Wood

Dr. George Woodward

Mr. Charlton Yarnall

The first problem which had to be solved before active preparation for the Show could be undertaken was that regarding the raising of funds to meet the probable expenditures. A subcommittee of the executive committee which was immediately appointed to draw up a tentative schedule of the estimated expenses, reported that the following expenditures would be necessary:

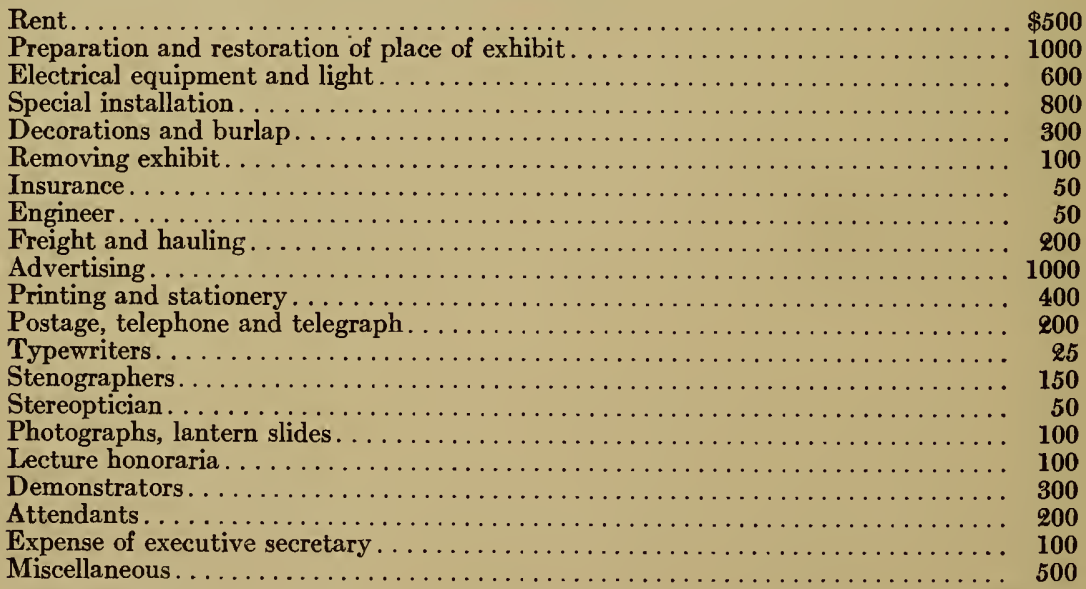

Total . . . . . . . .

To meet this expenditure (which was recognized as a minimum estimate) the finance committee immediately undertook the task of securing through personal solicitation thirty-five or more gentlemen each of whom would consent to become liable for the expense of the Milk Show to the maximum amount of two hundred and fifty dollars. The following gentlemen consented to act as guarantors, it 
being understood that any money which could be raised by a general letter of appeal, the sale of floor space to commercial exhibitors at the exhibition, voluntary contributions, or any other means, would be used to reduce the ultimate amount that the guarantors would be called upon to pay:

Mr. John E. Baird
Mr. Ellis A. Ballard
Mr. Samuel T. Bodine
Mr. Francis E. Bond
Mr. George Burnham, Jr.
Mr. William Burnham
Mr. E. B. Cassatt
Mr. C. Howard Clark, Jr.
Mr. E. Walter Clark
Mr. Morris L. Clothier
Dr. R. Norton Downs
Mr. George W. Elkins
Mr. George W. Elkins, Jr.
Mr. James Logan Fisher
Mr. William W. Frazier
Mr. Lincoln Godfrey
Mr. Charles C. Harrison
Dr. Richard H. Harte
Mr. Alba B. Johnson

Mr. John E. Baird

Mr. Samuel T. Bodine

Mr. Francis E. Bond

Mr. George Burnham, Jr.

Mr. E. B. Cassatt

Mr. C. Howard Clark, Jr.

Mr. E. Walter Clark

Mr. Morris L, Clothier

Mr. George W. Elkin

Mr. George W. Elkins, Jr.

Mr. James Logan Fisher

$\mathrm{Mr}$. Lincoln Godfrey

Dr. Richard $\mathrm{H}$ Harte

Mr. Alba B. Johnson

\section{GUARANTORS}

Having secured a sufficient guarantee fund to pay the expenses of the exhibition, the executive committee proceeded to apportion to each subcommittee the amounts as given in the preliminary estimate of expenditures.

In order to help defray the expenses of the Show, use was made of the newspapers in stating the need of such an exhibition and the consequent cost of the same; subscriptions were solicited personally by members of the executive committee; a general letter of appeal asking for financial support was mailed to over five thousand addresses; the Director of the Department of Public Health and Charities requested the Mayor to ask City Councils for an appropriation as the city's contribution; floor space at the exhibition was sold to commercial exhibitors at fifty cents a square foot; certified milk was sold during the Show; and bottles with cards reading "Contributions Toward the Expenses of the Milk Show May Be Placed in This Bottle," were placed about the exhibition rooms.

The question was raised as to whether it would pay to send out letters asking for financial support. It was decided, however, that such an appeal would at least more than pay for itself and would at the same time be an advertisement. The letter of appeal was enclosed in an envelope with a preliminary announcement folder, one of the small advertising cards such as were distributed to school children, and a return envelope addressed to the treasurer. This letter read as follows:

Dear Sir:

May 15, 1911

It is proposed to hold in Philadelphia, on May 20th to 27th, an exhibition showing in detail everything pertaining to the production of milk and its distribution, transportation, and care in the home. Good and bad conditions will be portrayed and the remedies shown. We request that you read the enclosed announcement.

To finance this exhibition, the coöperation of every public-spirited citizen is necessary. The subject is one which must appeal to all who are interested in the health of our community, especially as it relates to the welfare of the children. We request that you send us in the enclosed envelope as generous a subscription as possible. Check should be drawn to the order of Mr. E. T. Stotesbury, treasurer.

Yours respectfully,

(Signed) Jos. S. NefF, Chairman of Executive Committee.

(Signed) R. H. HARTe, Chairman of Finance Committee. 
A generous response from the following contributors was received in answer to this letter, the amounts received ranging from one dollar to five hundred dollars:

\section{CONTRIBUTORS}

Mr. John E. Baird

Mr. E. A. Baldwin

Mr. William P. Bancroft

Mr. Enoch A. Bandura

Mr. Charles T. Barney

Belber Trunk and Bag Company, Inc.

Bernstein Manufacturing Company

Mr. C. F. Bezold

Mr. Kenneth M. Blakiston

Mr. George L. Blatz

Mr. Henry H. Bonnell

Mrs. A. M. Boyd

Miss Ellen K. Brazien

Miss E. Josephine Brazier

Mrs. Anna L. Burnham

Mrs. George Burnham

Cash (3)

Mr. Charles W. Cathers

Mrs. Clarence M. Clark

E. W. Clark and Company

Mr. H. L. Clark

Messrs. Comly and Flanigen

Mrs. Mary E. Converse

Mr. John Conway

Mrs. Morris L. Cooke

Mr. Edward Cope

Mr. Henry L. Davis

Miss Lucy Davis

Mr. J. W. Detweiler

Mr. Jacob S. Disston

Messrs. John and James Dobson

Mr. Henry H. Donaldson

Miss Mary Dornan

Otto Eisenlohr \& Brothers

Mr. William Engel

Mrs. A. A. Eshner

Mr. George B. Evans

Dr. Clifford B. Farr

Mr. W. W. Frazier

Mr. George Geiss

Mr. Reuben C. Gilmer

Mr. William H. Greene

Mr. Joseph R. Grundy

Mr. F. T. Gucker

Mrs. A. P. Hadley

Miss Clementina Rhodes Hartshorne

Mr. Henry Hauptfuher

Mr. William B. Heackenberg

Mrs. Charles W. Henry

Mrs. Charles S. Hinchman

Messrs. Horn and Horn

Mr. Lardner Howell

Independent Milk Dealers' Association

Mr. Henry McKean Ingersoll

Mr. H. Harvey Ivins

Jacob Brothers

Mr. Henry S. Jeans .
Mr. John Story Jenks

Mrs. William F. Jenks

Mr. J. Percy Keating

Miss Florence Keen

Mr. T. W. Kester

Dr. E. L. Klopp

Mr. B. M. Lewis

Mrs. John Frederick Lewis

Miss Mary W. Lippincott

Mrs. Howard A. Loeb

Mrs. Charles H. Ludington

Mr. M. Luetz

Mr. John D. McIllheny

Mrs. Louis Childs Madeira

Mr. Otto T. Mallery

Mr. James N. Mohr

Mr. T. H. Morris, Miss Ellen Morris

Dr. John H. Musser

Mr. John S. Newbold

A. Newman and Company

Mr. John B. Parsons

Mr. Edward Pennock

Mr. J. N. Pew

Philadelphia Milk Exchange

Philadelphia Quariz Company

Miss Anna Randolph

Miss E. C. Roberts

Miss Emily L. Roberts

Miss F. A. Roberts

Miss Rosengarten

Mr. John M. Roshon

Mr. David J. Roulston

Miss Ada C. Sayen

Mr. A. G. Scattergood

Miss Mary C. Scattergood

Mr. Jacob Schonder

Mr. J. Harry Schurr

Mr. William L. Scott

Mr. Samuel Shapiro

Mr. John M. Sheerbaum

Miss Florence Sibley

Rev. and Mrs. Alexander Mackay-Smith

Mrs. James Spear

Mr. Frederick H. Strawbridge

Miss Elizabeth Swift

Mr. J. D. Thomas

Mr. Clarke Thomson

Misses Anges L. and Grace A. Tierney

Mr. Thomas C. Townsend

Dr. Joseph P. Tunis

Mr. Robert W. Tunis

Mr. S. M. Vauclain

Mrs. Henry M. Warren

Mr. Asa S. Wing

Mr. R. D. Wittington

Mr. Albert Wolf

Mr. J. F. Ziegenfuss

With regard to the financial settlement after the Show, it was decided that in order to close up the business with the treasurer as soon as possible, the total 
expenses should be reckoned slightly in excess of what appeared to be necessary in order to cover any possible outstanding deficit (unknown at the time of reckoning), with the provision that if there was eventually any small surplus remaining, this surplus should be donated to the Babies' Hospital of Philadelphia.

After deducting the receipts from the expenditures, it was necessary to call upon the guarantors to pay about forty per cent of the amounts originally guaranteed by them.

\section{FINANCIAL STATEMENT}

\section{Report of the Treasurer}

Expenditures:

1. Salaries and honoraria (including lecturers, demonstrators, stenographers, office-boys, engineers,

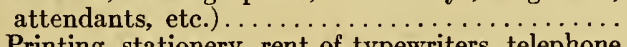

2. Printing, stationery, rent of typewriters, telephone

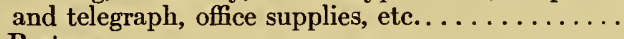

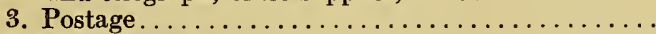

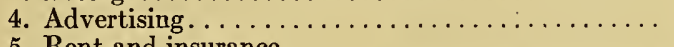

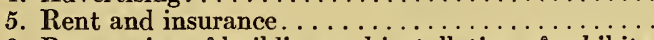

6. Preparation of building and installation of exhibits,

7. Electrical, lighting or plumbing equipment; special installation; heat, light, and power. . . . . . . . .

8. Freight, expressage and hauling. . . . . . . . .

9. Drawings, blue prints, charts, stereopticon and lantern slides, moving picture machine and films...

10. Specially prepared exhibits . . . . . . . . . . .

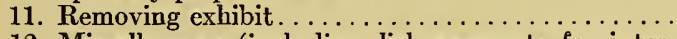

12. Miscellaneous (including disbursements for interest, car-fare, chairs, ice, repairs, hardware, materials, etc.) . . . . . . . . . . . . . . . .

Total expenditures

596.01

\section{$\$ 10,801.77$}

Receipts:

Subscriptions of $\$ 100$ and over

$\$ 1,900.00$

Subscriptions under $\$ 100$.

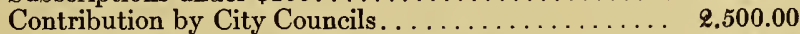

Sale floor space to commercial exhibitors......... 1,175.74

Sale light and power to commercial exhibitors ...... 4.42

Sale of milk and contributions received at Show . . . . $\quad 395.40$

Sale of special advertising milk bottle caps........ 299.61

Miscellaneous receipts................. 5.94

Total receipts. . . . . $\ldots \ldots \ldots \ldots \ldots \ldots \ldots \ldots \ldots \ldots, \mathbf{7 , 2 1 6 . 6 1}$

Total deficit to be paid by guarantors ........... $\$ 3,585.16$

Through the kindness of Mr. WillB Hadley, chief accountant in the office of the City Controller, and Mr. Lorin C. Powers and Mr. A. F. Lindberg, of the Bureau of Municipal Research, who contributed their services, the accounts have been duly audited and found correct. 


\section{Committee on Publicity}

Mr. Ghorge W. Ochs, Chairman

Dr. Jesse D. Burks, Secretary

Mr. James S. BenN

Mr. W. C. Craig

Mr. Arthur W. DUNN

Mr. Harrington Fitzgerald

Mr. Charles P. Garde

Mr. Max Heinrici
Mr. Hood MacFarland

Mr. Lewis H. McLaughuin

Mr. Louis Nusbaum

Mr. David E. Smiley

Mr. Roy Smith Waluace

Mr. Charles K. Weston

\section{Mr. Harry Wilson}

The membership of this committee consisted of the city editors of all the newspapers and other members especially appointed for the purpose of taking charge of the advertising. In order to differentiate clearly between the similar duties of this committee and those of the committees on education and social organizations, these committees held joint meetings. As a result, it was decided by the executive committee that the duties of this committee should be to provide copy for the newspapers and to prepare for the advertising of the Show.

In order to obtain the utmost publicity and to enlist the daily support of the newspapers, a letter was sent out to each paper requesting them to assign a particular reporter to the Milk Show. The committee next employed Miss F. A. Dawson, the assistant secretary of the Pennsylvania Society for the Prevention of Tuberculosis, to act as the publicity agent of the Show. A stenographer was employed to help with this work, and copy was prepared daily for all the morning and evening papers and delivered to the reporters who had been assigned to this work.

To secure news items the publicity agent attended meetings of the various committees and interviewed speakers and prominent visitors. Letters were sent to the speakers on the various programs, asking them to furnish in advance brief abstracts of their addresses, and much good material for the papers was secured in this way.

Besides the newspaper copy prepared by this committee, additional copy was written for the country newspapers by the committee on dairy institutions and milk contests, and the committee on social organizations furnished material to many of the purely local newspapers and papers published in foreign languages. The news clippings on the Milk Show as preserved in the office of the executive secretary are known to be incomplete; no clippings at all are included from at least one of the well-known city papers; none of the papers printed in foreign languages or local ward papers are included; and many items published in foreign papers are also missing. An analysis, however, of the clippings at hand shows that in nine city papers there appeared one hundred and sixty-one different items which occupied about seventeen hundred and seventy linear inches of column space, or over one hundred and fortyseven feet. Seventy-five foreign papers (or those outside this city), in twentyfive states, published eighty-five items which occupied about five hundred and twelve inches of space, or over forty-two feet.

The question concerning the most effective advertising for the Show was most important. The various methods considered by the committee are included in the list which follows, and those suggestions which are prefaced with an asterisk $\left(^{*}\right)$ were adopted by the executive committee as being most practicable and within the financial appropriation set aside for this committee: 
1. Publicity through the press:

a. News matter in various city newspapers (including papers in foreign languages).

b. Associated press notices.

c. Advertising ,matter (possibly contributed by department stores).

2. Publicity through the churches:

a. Notices and bulletins.

b. Verbal notices by ministers to congregations.

c. Printed matter for distribution to ministers.

3. Publicity through schools:

a. Announcements by teachers.

b. Small advertising cards for distribution by teachers to pupils.

c. Distribution of celluloid buttons to school children visiting the Show.

4. Large billboard posters in city and adjacent suburban districts.

5. Cards in show windows of stores.

6. Street cars:

a. Advertising cards inside cars.

b. Signs on fenders during week of Show.

7. Electric signs on City Hall.

8. Hand-bills and circulars (especially in foreign languages).

9. Social agencies. Statements explaining the purpose of the exhibit, with request for coöperation of social workers in various social agencies and distribution of small advertising cards (especially in foreign languages).

* 10. Hand-book or guide to the exhibition, explaining the significance of the various parts of the Show.

11. Other printed matter. Leaflets and wall-cards for distribution, explaining points of interest in the Milk Show.

12. Special milk caps or tags. Request milk dealers to use milk caps or tags of special design on all milk bottles distributed during a specified period.

13. Brief announcement slips advertising the Milk Show, the milk contests and the Dairy Institute to be sent to all farmers.

14. Special school children's day. A definite period reserved for pupils in upper grades.

* 15. Sign at entrance over street.

16. Pay day. One or more mornings, or a special day set apart for paid admissions.

17. Baby day or baby week. Special attention directed to relation of milk or infant welfare through schools, churches, department stores, labor unions, moving picture shows, etc.

* 18. Special pictorial design to be adopted for use on printed matter, handbooks, advertising placards, etc.

* 19. Display cards to be posted on bulletin boards of suburban railroad stations and in subway and elevated railway stations. 
In addition to this publicity and advertising, much was accomplished through the publication of the preliminary announcement folder and also through notices which were sent out to about fifty of the country newspapers.

The committee on publicity reported to the executive committee that one of the billposting companies would place seven hundred and fifty large billposters throughout the city for five hundred dollars, but it was decided that this expenditure would not be warranted in view of the fact that only one thousand dollars had been set aside for all advertising. It was, therefore, decided to put the stress of the advertising upon an issue of two hundred and fifty thousand small three- by fiveinch cards which were printed on variously colored stock and in English, Yiddish, Italian and Polish. The English cards read as follows:

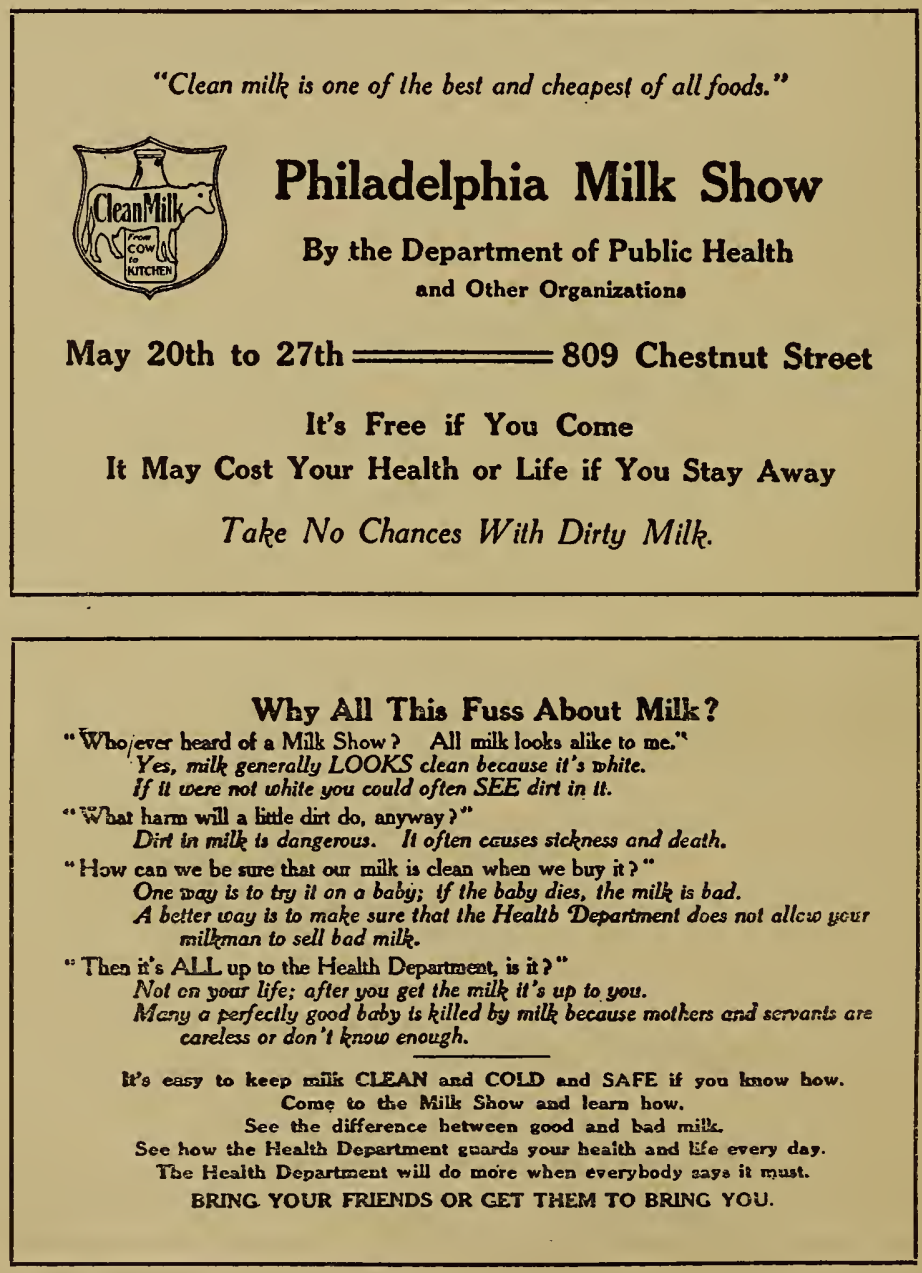

Through the coöperation of the Board of Public Education, one hundred and seventy thousand of these cards were distributed to all school children in the seventh 
grade or above; and through the coöperation of the Children's Bureau, the Armstrong Association, the Home and School League, and other like institutions, seventy-five thousand more of the cards and thousands of the preliminary announcement folders were distributed in the poorer sections of the city where they would do the most good.

For display advertising in the show windows of stores, upon the bulletin boards of subway, elevated and steam railway stations, and within street cars, two colored cards were prepared like the inserted illustrations.

Through the courtesy of the Philadelphia Rapid Transit Company and The Car Advertising Company arrangements were perfected whereby cards were displayed within street cars and in the advertising places in subway and elevated railway stations; and during the period of the Show, white linen signs measuring thirty-one inches by forty inches, printed in red, reading:

\section{FREE MILK SHOW 809 CHESTNUT STREET}

were tied to the fenders on the front of street cars.

The Pennsylvania Railroad Company and the Philadelphia and Reading Railroad Company likewise coöperated, and had these cards posted on all stations within the city and in the adjacent suburban districts.

The placing of the cards in various stores and shop windows was intrusted to a commercial advertising company.

A process letter was sent to all the city milk dealers asking them to use special milk bottle caps and so advertise the Show. The letter read as follows:

DeAR Sir:

May 3, 1911

You doubtless know of the Milk Show to be held in this city during the eight days, May 20-27. The purpose of the show is to create a demand among the people of Philadelphia for the best milk that can be produced. The Show is therefore being planned "to enlighten; not to frighten."

In order that all of the producers may know of this Show, it has been suggested that much good would probably result if dealers would be kind enough to include a brief announcement slip in their monthly remittance letters to dairymen. We are therefore enclosing herewith a quantity of these announcement slips. Will you not favor us by helping to advertise the Show in this way?

As a further means of advertising the Show, a milk cap of attractive design is to be provided for use by progressive dealers during the first days of the Milk Show and a few days preceding - eight days in all. The design is a shield on which appear a cow and a milk bottle. The only words on the cap are "Clean milk from cow to kitchen. Philadelphia Milk Show. Dobson Building, 809 Chestnut Street, May 20-27. Admission free."

Will you use these caps on your bottles for eight days? They will be furnished at 15 cts. per thousand. Orders must be placed at once so that the caps may be ready for delivery at the time required. Please inform us as to the number you will require, with shipping directions.

$$
\begin{aligned}
& \text { Very truly yours, } \\
& \text { JOSEPH S. NEFF, }
\end{aligned}
$$


Arrangements were made with a dairy supply company to furnish these caps at regular market rates. The caps were printed in red as follows:

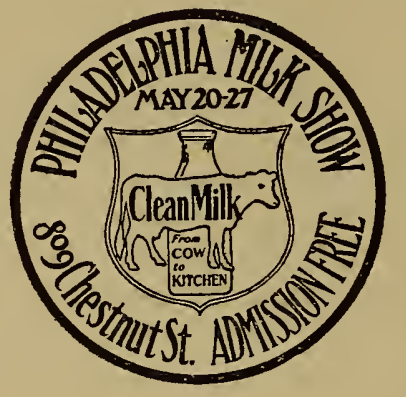

Fifty thousand celluloid buttons, stamped with this same design, were distributed to children visiting the Show.

The attendance figures attest to the fact that the advertising was well done considering the amount of money applicable to this purpose.

\section{Committee on Procuring Exhibits}

Dr. Lawrence F. Fuck, Chairman

Dr. Frank A. Craig, Secretary

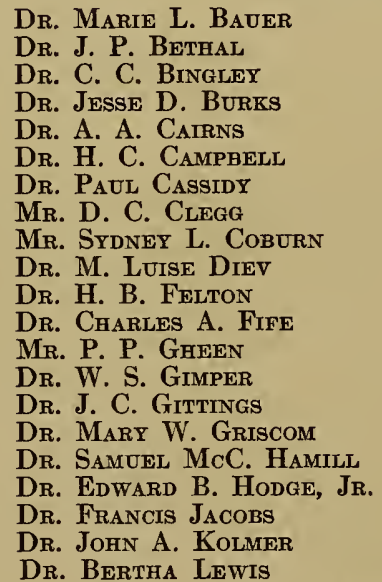

Dr. Paul A. Lewis

Dr. R. S. McCombs

DR. J. W. McConnell

Dr. J. H. McKeE

Dr. C. J. Marshall

Dr. H. D. Martien

Dr. K. F. Merer

Dr. Charles Montgomery

Dr. Arthur Newlin

Dr. S. W. NewMayer

Dr. W. T. Rees

Dr. John Reichel

Dr. W. D. Robinson

Dr. R. C. Rosenberger

Dr. Frances R. Sprague

Dr. James Tallex

Mr. Roy S. Wallace

DR. JOSEPH WALSH

Dr. Esther M. Weyle

Dr. C. Y. White

Mr. Edward Woolman, JR.

Mr. Frank A. Wills

This committee was held responsible for procuring all the exhibits (whether educational or commercial) including the delivery of shipments to the exhibition rooms and, finally, the return of the same after the closing of the Show. 


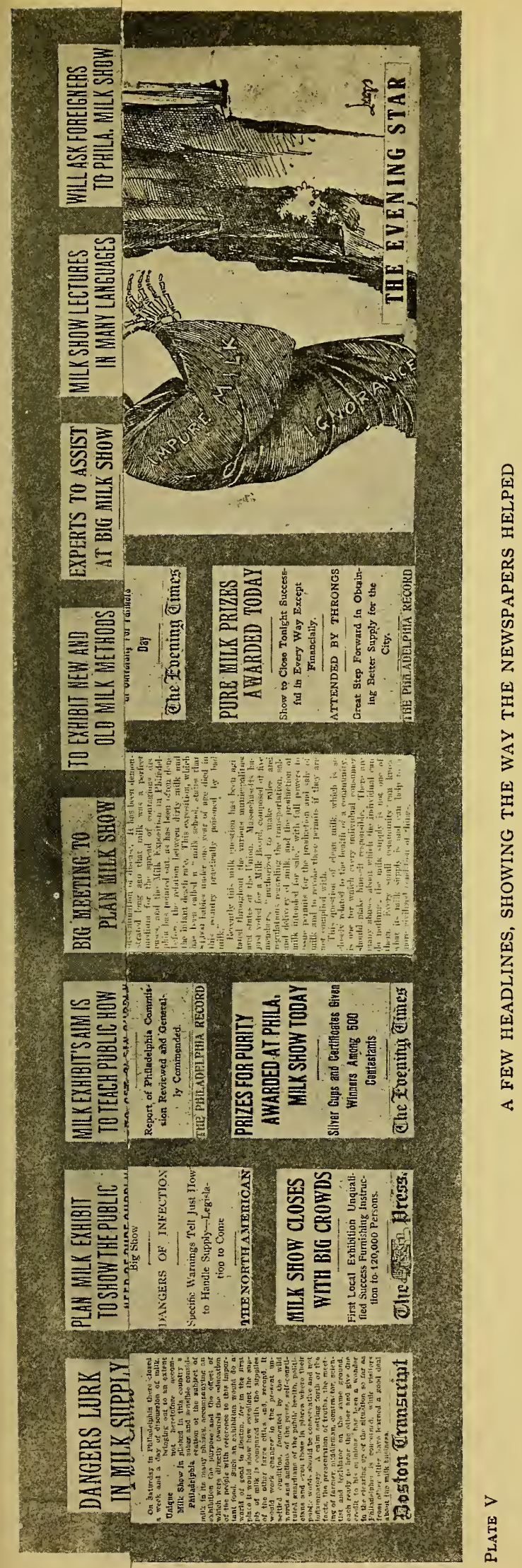





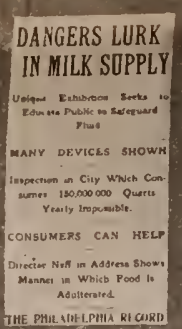

EXPERTS TO SPEAK AT U. OF P. OALY IMSTITUTE

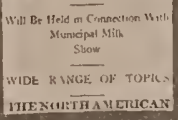

CHILDREN LEARN

LESSONS IN MILR

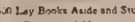

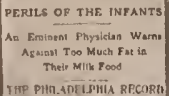

NEW ATTRACTIONS AT TEE MILK SHOW

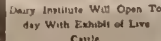
IMCREASED ATTENDANCE

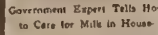
THE PHILADD. PIIIA NECCIRD

FARMERS IVTERESTEO IN OAIRY INSTITUTE

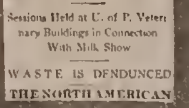

INTEREST GROWS

IN MILK CRUSADE

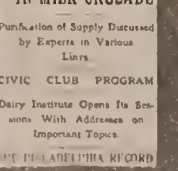

CLEYELAND MAY GET MULKSHOW THIS SUMMER The Cleveland Press

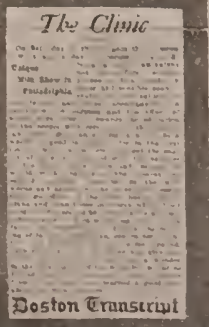

\section{PLAK MILK EXHIBIT TO SHOW THE PUBLIC NEEO OF PURE SUPPLY \\ Diressor Ven Forward,

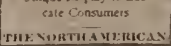

AJO FOR MLLX SHOW

PLEASES REYBURH: PRAISES OBIECT

"Sizads tor Elean Hoses and Well-
Iro Baties" Assars Encutin

The Ebenins ฮิmes

EXPERTS TO TAKE

UP MILK PROBLEM

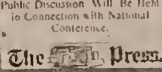

\section{MILXEXHIBITS SAIM IS TO TEACH PUBLIC HOW TO GET CLEAK SUPPLY \\ Mas AIs Help is End Hat Trade

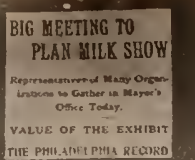

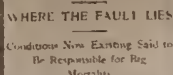

THEXORTIINURLCAS

PURE MILK SHIW

REAOY FOR ITS PUPUIG OPENING

Sanitan Exibils by Mational ant State Cousaission hin

Placel on Vit

厄he Fontuing e imes

HARO WORX FOR MILK SHOW

THE PHICADELPHAS RECORD
SAVING OF BABIES

AIM OF MILK SHOW

BEGINNING TOOAY

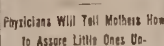

adutarated food

The Tosninn Cimes

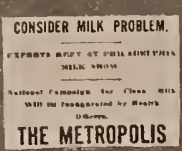

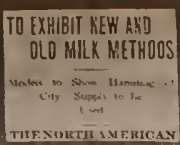

CONSUMERS SEE SAMITARY WAY TO SELL MILK

Mikk Show Opens With Large AHendance of Users and
Dealers
LECTURES ARE TO LECTURES ARE TO
BE GIVEN EACH DAY

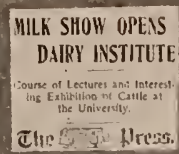

$$
\text { spe }
$$
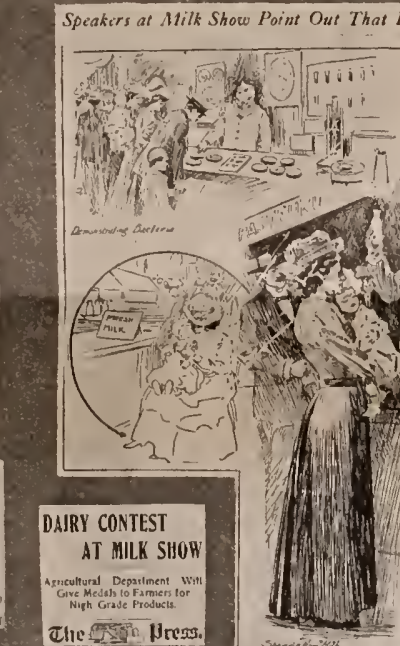

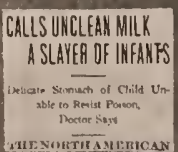

DAY FOR MOTHERS

AT MILK EXHIBIT

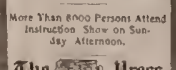

Elie rot Nress

-OON'TS FOR THE PUBLLC IN THE CARE OF MULK

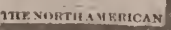

MILK SHOH CLOSES RITH BIC CROH'DS

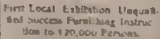
The SEx Mress.

Is II'oman's Duty to Kicp Supply Clean Affir It Leazes Draler

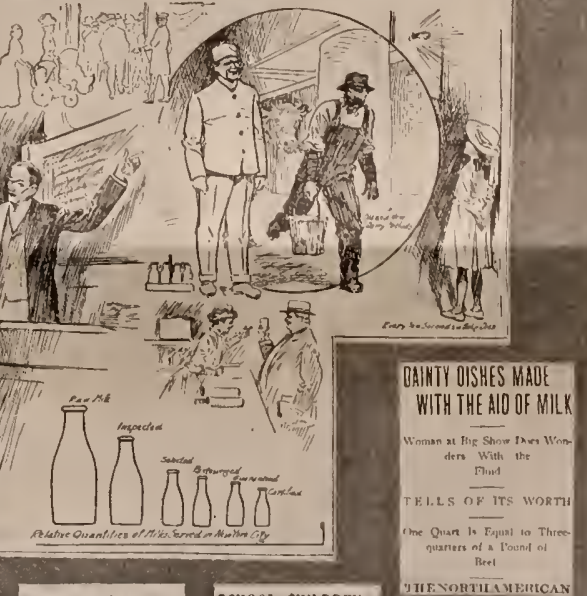

ERIE. DISPATCH

WLL AWARD MEOALS
TO MLL PROÓUCERS

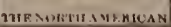

EXPERTS PRAISE SCOPE OF MULKSHOW HERE

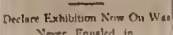

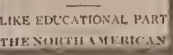

RECORA ATEKOHCE OH Mik SHOW's UST ory

The Tocninı Eimes

LIVE CATTLE USED

IN DEMONSTRATING

DAIRY SANITATION

CITY OU⿴囗十T TOTIST

AND PASTEURIZE ITS

MLLK, DOCTOR SAYS

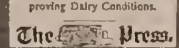

The Grint Hress

The Xocninu eintes
EXPLERTS TO ASSLST

AT BIG MLL SHOW

SUNDAY THRONGS

AT THE MILK SHOW

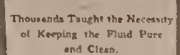

LEsSOH POR CHLLDKEN

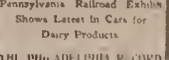

Ebe Jntellignter.
The

WILL ASK FOREIGKEAS

TO PHILA. MILK SHOW

Mal thisian

NTEREST IS GEYERA

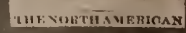

MILK SHOW FACTS LD IN YIDDISH SUNDAY CROWDS
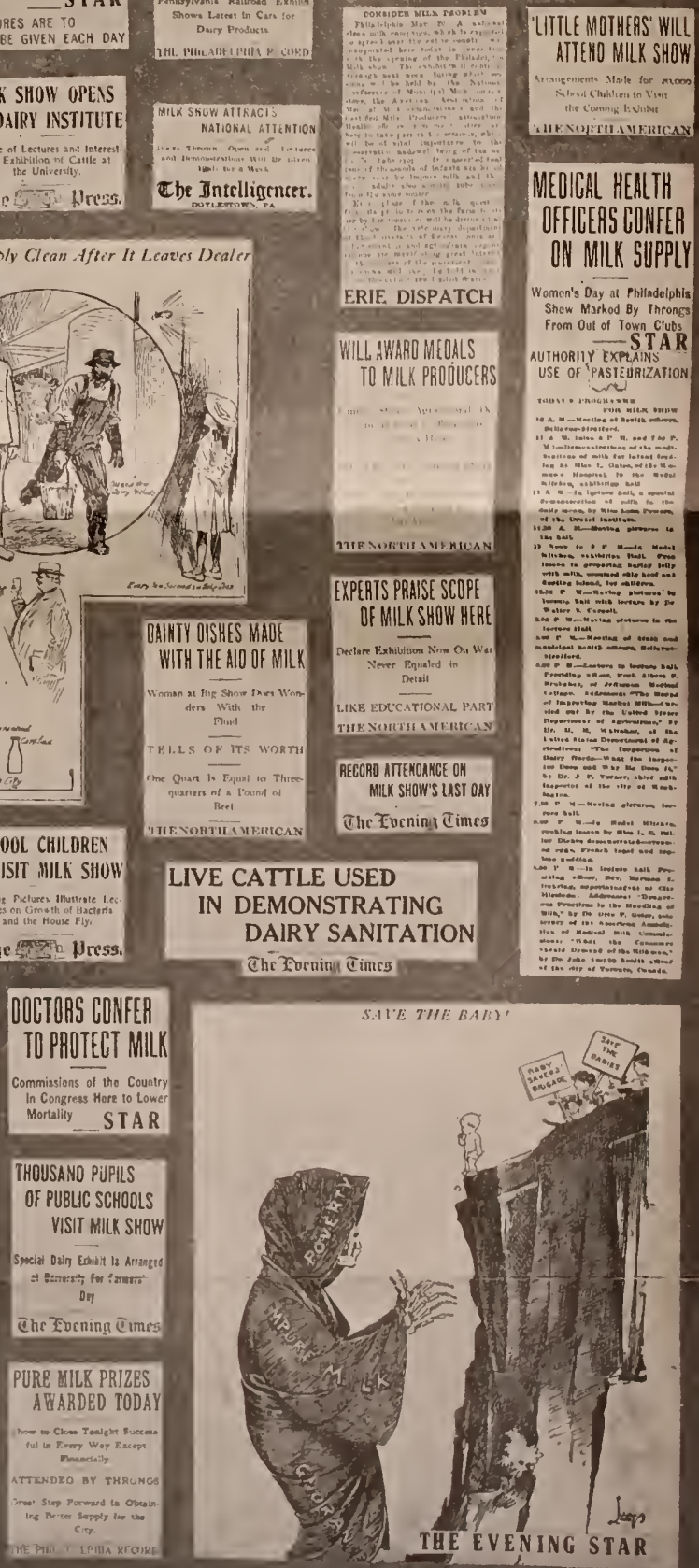

In planning the work of this committee, a proposed list of exhibits was prepared, similar classes of exhibits being grouped together. Subcommittees were next appointed, each of which was made responsible for the procuring of all the exhibits of one general class:

Class A. Modern laboratory equipped with apparatus used in the examination of milk. Demonstration of methods; effect of temperature on bacterial growth. Methods of examining milk to show accurate and well-applied tests of milk; chemical and physical qualities; adulterations, alterations, and impurities of every sort.

Class B. Reproduction of model stable and reproduction of a poor stable. Exhibit of tuberculosis in cattle. Exhibits from the United States Government. Exhibit by the producers of certified milk. Pyramid of bottles in iced cases to be renewed each day, and to have next to it a stand from which certified milk is sold at the market price. Exhibit of model of Neill-Roach Farms, Louisville, Ky., and French Brothers' Farm, Cincinnati, Ohio. Exhibit from railroad companies, plans and photographs of refrigerator cars and icing stations.

CuAss C. Charts of milk-borne epidemics of typhoid fever and other infectious diseases (Bureau of Health). Exhibits of New York Milk Committee and the Modified Milk Society. Graphic demonstration of relative value of various food products as compared with milk. Exhibit from New York Department of Health. Exhibit from Department of Health, state of Maryland. Exhibits from other states and cities. Infant mortality in relation to milk. Red light flash indicating infant mortality death-rate (after the plan used at the Baltimore Conference on Infant Mortality).

CLAss D. Methods of taking samples by city milk inspectors, and forwarding the same to the laboratory. Demonstration of proper methods of capping, marking and dating bottles.

Class E. Demonstration of proper and inexpensive means of preserving milk in the home.

Class F. Demonstration of visible dirt in milk and its composition by means of separators. Butter and cheese exhibits and appliances used in manufacturing them. Methods of manufacturing ice cream. Dairy equipment and appliances.

Class G. Exhibit of Veterinary Department, University of Pennsylvania (tuberculosis).

CLASS H. Moving pictures of milk and handling milk on bad dairy farms and on good dairy farms. Photographs of milk wagons and receiving stations. Photographs of the interior of places in which milk is sold. Photographs of places in which ice cream is made.

Class I. Commercial exhibits.

The chairmen of these subcommittees were each made individually responsible for the securing of the exhibits included in their respective classes; their receipt 
at the railroad stations or delivery to the exhibition rooms; and the proper return shipment after the Show. Each chairman had the privilege of appointing as many associate members as needed.

The first point to be determined was that concerning the general character of the exhibits in each class, and, in this regard, the committee was careful lest some exhibit should be made which would disgust visitors with milk as a beverage, although it was desirous that exhibits should be made with the idea of impressing on visitors the importance of clean milk. The approximate amount of floor space required for each exhibit was next estimated by the subcommittees and reported to the main committee. After consulting the floor plans of the exhibition rooms, as drawn by the architects, the floor space asked for was at once assigned to each subcommittee in accordance with the amount of floor space available, at the same time, attempting to keep the exhibits in a rational sequence.

After consultation with the committee on arrangements in general, it was decided that this committee should be responsible for the transfer of exhibits to the exhibition rooms from the railroad stations and for the return of the exhibits after the Show. Specific shipping directions were furnished to all exhibitors. Shippers were instructed to attach an envelope to each shipment, containing a description of the contents and explicit instructions regarding the handling of the exhibit, a duplicate of this description and instructions to be forwarded to the committee on arrangements in general. (See committee on arrangements in general, p. 23.) Dates were set for the receipt, installation and removal of exhibits. Estimates were prepared of the number and kind of counters, tables, railings, etc.; water, gas, and electricity connections; and the specifications of posters and signs required, and the committee on arrangements in general notified to provide the same.

Commercial exhibitors were charged fifty cents a square foot for floor space and all commercial exhibits were carefully censored. The following letter was sent to prospective exhibitors in this class:

Dear Sirs:

May 2, 1911

As the letter indicates, a Milk Show is to take place at 809 Chestnut Street, from May 20th to May 27th. We have a certain amount of space for commercial exhibits and would be glad to hear from you if you wish to exhibit. The charge for space will be fifty cents per square foot. Since the amount of space is limited, it would be worth while applying as soon as possible.

\author{
Yours very truly, \\ Joseph Walsh, 732 Pine Street, \\ Chairman Committee on Commercial Exhibits.
}

Accompanying this letter was a blank or contract, to be used in applying for space, and on the reverse side, the regulations regarding commercial exhibits. (For reprint, see appendix E on p. 106.)

One of the commercial exhibits was so heavy that it could not safely be installed with the remaining commercial exhibits on the second floor and it was, therefore, installed in the lecture hall on the first floor of the adjoining building. Certain privileges were conceded to commercial exhibitors; namely, milk dealers asked to be allowed to give a glass of milk to each visitor; an exhibitor of cheese and butter wished to give away samples on crackers; and another exhibitor of milk-chocolate wished to give away samples of his products. No commercial exhibitor was allowed to sell samples. 


\title{
Committee on Lectures and Demonstrations
}

\author{
Dr. E. J. C. Beardsley \\ Dr. W. N. BRadley \\ Dr. Edward B. Hodge, Jr. \\ Dr. WARD Brinton \\ Dr. H. R. M. Landis \\ Dr. J. D. BRItTingham \\ Dr. Alexander Davisson \\ Dr. H. KenNedy Hill \\ Dr. Theodore LeBoutillier \\ Dr. C. J. Marshall \\ Dr. H. Brooker Mills \\ Dr. JohN F. Sinclair
}

Dr. J. T. Rugh, Chairman

The duties of this committee were to prepare the program of daily lectures and to provide demonstrators to explain the various exhibits. Several of the speakers whom this committee desired to secure for addresses, were also desired by the committee on dairy institutes and milk contests and the committee on the conference of health officers. These three committees therefore held joint conferences and all the programs were worked out so that no conflicts of appointments occurred. For example, arrangements were perfected so that a speaker, desired by all three committees, could address the Conference of Health Officers in the morning, the Milk Show in the afternoon and the Dairy Institute the following morning. When necessary, the expenses were paid of speakers coming from a distance. A few days before the opening of the Show, copies of the printed programs were sent to all presiding officers of meetings and all speakers with the name and date underscored as a reminder of such engagements.

A schedule of hours covering the entire Show was arranged and capable demonstrators were provided at all times to take groups of visitors around the Show rooms, answer questions and speak about the salient points of the various exhibits. On Sunday one of the demonstrators gave explanations in Yiddish. Demonstrators were paid the nominal sum of one dollar an hour for their services.

This committee succeeded in gathering together a notable list of speakers who delivered a most interesting series of addresses, and the great educational value of the verbal explanations of the exhibits was evidenced by the large crowds that thronged the booths when the demonstrators were explaining objects and processes.

\section{Committee on Conference of Health Officers}

Mr. John A. Vogleson, Chairman

Dr. A. C. Аввотт

Dr. A. A. Cairns
Dr. W. L. CopurN

Dr. D. Braden Kyle

\section{Dr. Joseph S. NeFF}

This committee was charged with the preparation of arrangements for the Conference of Health Officers to discuss the report of the Philadelphia Milk Commission. The Hotel Bellevue-Stratford was secured as a meeting place and a program prepared, copies of which were mailed to all the health officers of Pennsylvania, Maryland, New Jersey and Delaware, and the large cities throughout the country. The complete program is given in appendix $\mathrm{B}$ on p. 87 . 


\title{
Committee on Education
}

\author{
Mr. Alexander M. Wrison, Chairman \\ Dr. Martin G. Brumbaugh \\ Dr. Charles A. Fife \\ Dr. Walter S. Cornell \\ Mr. William A. Stecher
}

Owing to the brief period of time before the opening of the Show, the labors of this committee were concentrated upon the preparation of a series of educational leaflets for free distribution at the Show; the printing of the program and a pamphlet containing the members of committees and lists of patronesses; and the perfection of arrangements whereby the school children in the higher grades could attend the Show.

This committee was not in favor of the publication of an extensive hand-book for the exhibition, but recommended that separate leaflets on different subjects relating to milk be prepared, believing that these leaflets would be more suitable because of both the shortness of the time which was available for the preparation and the necessary large expense in the publication of a book.

In addition to the work done by the members of this committee in the preparation of the leaflets, invaluable help was rendered by Dr. E. G. Marshall, Dr. Alonzo E. Taylor, Dr. Alfred Hand, Dr. Joseph S. Neff, Dr. Edwin E. Graham and Mr. Porter R. Lee. The leaflets are reprinted in full, in appendix D, p. 92.

The main idea followed in the preparation of these educational leaflets was to obtain an attractive, interesting and authentic series of truths on all the various phases of the milk problem, so composed and printed that the public would take them home and read them. These leaflets were standardized as to size and composition, and were punched so that, with the cover that was provided, the entire collection could be bound together with a string for safe keeping. The cover was prepared of fairly heavy cardboard and served, when the leaflets were included, as a hand-book of the exhibit, containing in brief, clear language the principal lessons to be learned from the various exhibits and addresses.

During the period of the exhibition two hundred and forty-five thousand of these leaflets of strictly educational nature were distributed, costing three hundred and ninety-eight dollars. Twenty-five thousand programs were printed and distributed at a cost of sixty-seven dollars, and ten thousand of the special leaflets, containing the members of committees and lists of patronesses, at a cost of one hundred and twenty-six dollars. Since it was impossible to estimate with any degree of accuracy previous to the opening of the Show, how many of the various leaflets would be required, it was necessary to give the committee the authority to order them as required.

This committee recommended that the following statement should be printed in the program exculpating the Milk Show from responsibility in connection with any declarations which might be made by commercial exhibitors:

Although the Philadelphia Milk Show has tried to censor the commercial exhibits properly, it cannot hold itself responsible for statements or opinions expressed by commercial exhibitors, nor particularly recommend their products above other similar ones.

One of the most valuable accomplishments of this committee was the arrangement with the Board of Public Education and the street railway company, whereby 


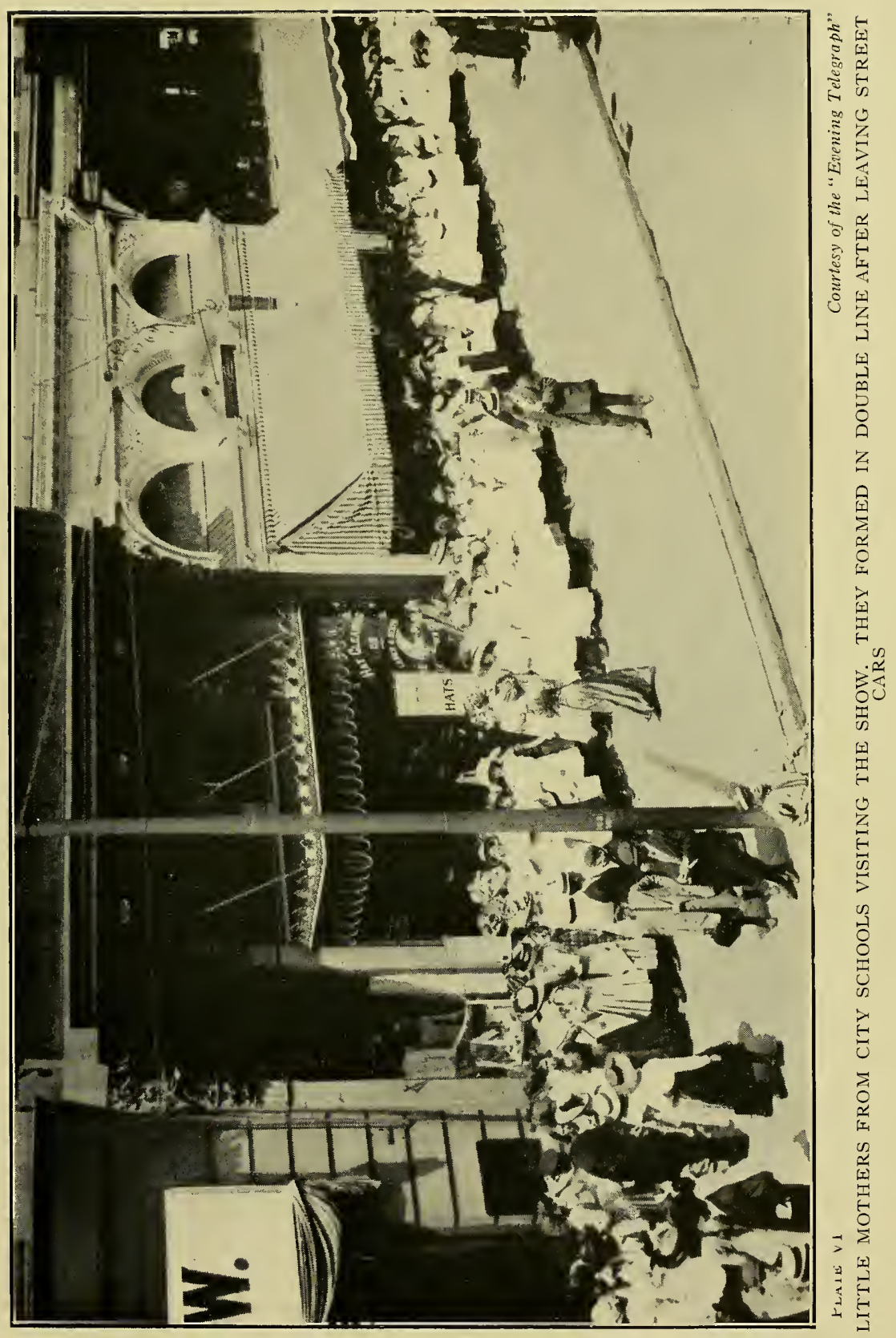



it was made possible for all the school children in the seventh and eighth grades to attend the Show. Through the kindness of the Philadelphia Rapid Transit Company, these children were transported free in special cars.

The method of handling the children on coming to the Show was most carefully planned. All children were accompanied by their teachers and were kept in double line, entering the exhibition by the main front entrance and leaving by the rear exits. Their progress through the exhibition rooms was necessarily somewhat hurried, but, even so, it is probable that they absorbed many lessons and in many cases upon their return home interested their parents to the point of attending the Show.

It was generally desired that all the children see the moving pictures, yet this proved to be impossible, as the lecture hall seated only about three hundred and fifty and between two and three thousand children visited the Show each afternoon from one to three o'clock. Since it took twenty minutes to display one film and ten minutes to fill and empty the hall, making thirty minutes in all, it was obviously impossible to have all the children see these pictures, so the only thing to be done was to fill the hall with as many children as possible.

Regarding the distribution of the educational leaflets during the Show, the method followed was to give copies of all the leaflets to every visitor. During the first two days much of this literature was thrown aside in the show rooms and woefully wasted. It was deemed advisable, however, to continue to distribute this literature as had been started, even though much was wasted, believing that, the wider the circulation of these educational leaflets, the more good would ultimately result. This policy proved to be well founded, for as the Show progressed and the community began to realize its great value, the leaflets were eagerly accepted and preserved. In fact, the demand for the leaflets was so great that, for brief periods on certain of the heaviest days, the supply was exhausted before additional quantities could be secured from the printers. The waste which had been so apparent at the start of the Show was entirely lacking at the close.

In addition to the educational leaflets, a supply of an instructive wall placard was kindly furnished by the Russell Sage Foundation for free distribution. This placard, portraying in parallel columns contrasting conditions in the production, handling, distribution, and use of milk, is reproduced on the plate facing p. 38 .

\title{
Committee on Dairy Institutions and Milk Contests
}

\author{
Dr. Louis A. Klein, Chairman \\ Mr. A. B. HUEY \\ Dr. C. M. Seltzer \\ Mr. Frank Trtus \\ Mr. Henry Woolman
}

The chief duties of this committee were the preparation of a program for the three days' sessions of the Dairy Institute; the making of arrangements for the meetings of the Institute; the installation of an exhibit showing, under the same roof, good and bad types of dairy stables; the composition of copy concerning the 
Milk Show and the Dairy Institute for country newspapers; and the arrangements for holding the milk and cream contests.

The program for the Dairy Institute was easily arranged by correspondence, after this committee had consulted with the committee on lectures and demonstrations and the committee on conference of health officers so that no conflicts would ensue. The complete program is reprinted as appendix C on p. 89 .

The Veterinary School of the University of Pennsylvania was an ideal meeting place for the Institute, since it was easy of access, commodious lecture rooms were available, and the courtyard furnished the necessary space for the reproduction of the dairy stables. The Dairy Institute, including a description of the stables, is reported in detail on p. 47.

This committee also completed all the details and arrangements for holding the milk and cream contests. Dr. George M. Whitaker, chief of the Dairy Division of the United States Department of Agriculture, was secured as judge of awards and to have general supervision over the contests. Entry blanks for each of the four classes, (1) certified milk, (2) certified cream, (3) market milk, and (4) market cream, were printed. (For reprint of these entry blanks refer to appendix F on p. 108.) A supply of addressed shipping tags for use in forwarding milk samples was also provided. (For reproduction of tag, see plate facing p. 16.)

Small three- by five-inch notices were also printed calling particular attention to the Dairy Institute to be held at the Veterinary School of the University of Pennsylvania. (See plate facing p. 16.)

The names and addresses of over five thousand farmers shipping milk to Philadelphia were secured from the Division of Milk Inspection of the Bureau of Health and entry blanks for the market milk and cream contests were mailed to each producer. Enclosed in each envelope, besides the two entry blanks, were two shipping tags, a notice of the Dairy Institute and a preliminary announcement folder of the Milk Show.

In addition, a supply of entry blanks for the certified milk and cream contests, with shipping tags and other literature, was mailed to all the secretaries of the certified milk commissions throughout the country with a letter reading:

DeAR Doctor:

May 3, 1911.

We enclose herewith several entry blanks for certified milk and cream for the milk contests to be held in Philadelphia in connection with the Milk Show, May 20th to 27th. Will you be kind enough to place one copy of each form of entry blank in the hands of those persons producing certified milk under the supervision of your commission?

Very truly yours,

Lodis A. KLeIN, Chairman of Committee.

The results of the milk and cream contests are reported in detail on p. 48 . 


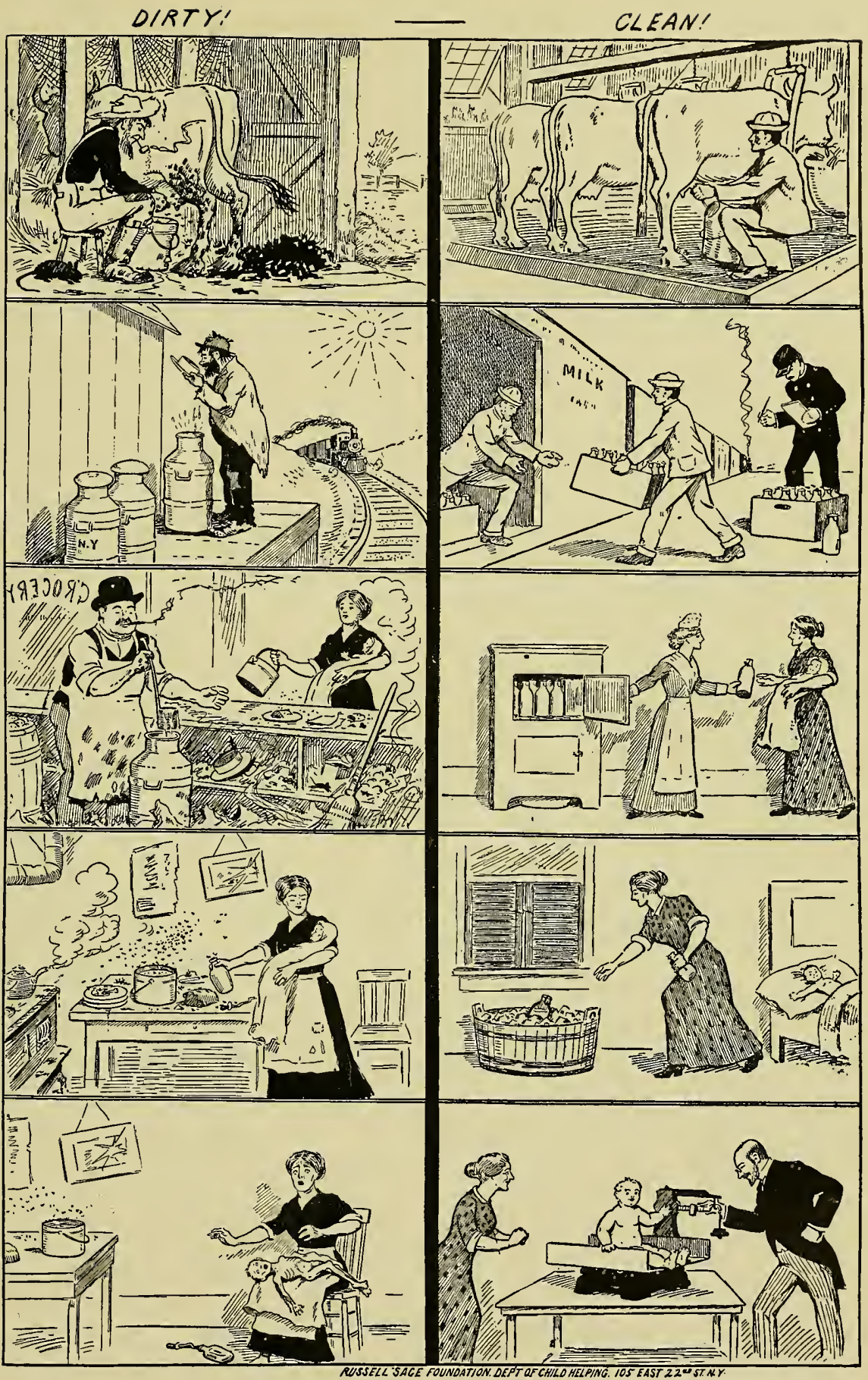

Plate VII

Size OF DRAWING, $93 / 4$ INCHES By 15 InChes

EDUCATIONAL PLACARD DISTRIBUTED TO VISITORS. FURNISHED BY RUSSELL SAGE FOUNDATION 



\section{Committee on Social Organizations}

Mr. J. Prentice Murphy, Chairman

Mr. Charles T. Walker, Secretary

\author{
Mr. Joseph Bartilucci \\ Mr. Henry H. Bonnell \\ Mrs. R. R. P. Bradford \\ Mr. Joseph Di Silvestro \\ Rev. J. P. DUfFY \\ Rev. H. L. DUHRING \\ Mr. John T. EMLen \\ Mr. Thomas S. Evans \\ Mrs. W. W. Frazier \\ Rev. Carl E. Grammer
}

\author{
Mrs. Edwin C. Grice \\ Mr. JAMES Hickey \\ Mr. B. F. LeE, JR. \\ Miss Margarex Lemman \\ Rabii B. L. Leventhal \\ Mrs. Louis C. Madeira \\ Misg Katherine Melley \\ Miss Laura N. Platx \\ Miss Florence L. Sanville \\ Mr. Edwin D. Solenberger
}

It was necessary that this committee should work harmoniously with the committee on publicity and on education and should be kept informed of the plans of these two committees, for the reason that much of the work covered closely related phases of the same field. This committee therefore held several joint meetings with these committees, otherwise there would probably have resulted much duplication of effort. This committee at the start instituted a very active campaign with the various social organizations in the city, in order that through them the great mass of working people might be notified of the exhibit and urged to attend. To enlist the support and to secure the endorsement of the Milk Show movement by the various hospitals, day nurseries, social clubs, and other charitable organizations, a process letter including a preliminary announcement folder and two of the small advertising cards was sent out to the officers and directors of such institutions. The letter read as follows:

May 15, 1911

\section{DeAR Sir:}

The enclosed preliminary announcement will explain the purpose of an exhibition which is to be given as a means of educating the public to the necessity for producing and handling milk in a sanitary manner and the value of good milk as a food in the home.

By direction of the executive committee I am writing you for the purpose of securing the endorsement of your society in our general plan and possibly the aid which you can render in the promotion of this coöperation. To this end we are asking permission to use your name as one of the coöperating agencies which are actively interested in the promotion of such an educational exhibit. Will you kindly give this request your immediate attention and the possibilities of the Show wide publicity and let me have your answer at the earliest moment? Believe me,

After careful discussion as to the various ways and means whereby the social organizations in the city could be used most effectively as distributing centers for information concerning the Milk Show in order to drive home the principles back of the Show, it was decided that the problem of reaching the large foreign population could best be handled by appointing subcommittees to take charge of this work. For example, one of these subcommittees was able definitely to reach all the Italians and Jews, thereby explaining the purpose of the Show and disarming the recently arrived emigrant of any misgivings concerning the Show. Certain members of this committee were in close touch with all of the Jewish and Italian newspapers and supplied material for their columns, and copy was also supplied to certain other papers which are printed in various parts of the city and which are strictly local in their character. Another subcommittee was in touch with the associations of neighborhood workers (which included all the settlements of Philadelphia) and the 
Philadelphia Association of Day Nurseries. Through these two agencies alone, many thousands of mothers were reached. Another member of the committee was associated with certain trade organizations and also reached several of the social clubs for girls.

\section{Committee on Patronesses and Aides}

Mrs. Talcott Williams, Chairman

Miss Gertrude E. Leidy, Secretary

Mrs. Cyrus Alder

Mrs. Jasper Y. BrintoN

Mrs. Edward P. Davis

Miss Henrietta B. Ely

Mrs. Chancellor C. English

Mrs. Edward Beecher Finck

Mrs. Edwin C. Grice
Mrs. William F. Jenks

Mrs. William M. KerR

Mrs. R. Tait McKenzie

Mrs. James P. McNichot

Mrs. George Wharton Pepper

Miss Frances A. Wister

Mrs. OWen Wister

The chief duties of this committee were to enlist the support and coöperation of the various hospitals and to attend to the distribution of the educational leaflets at the exhibition rooms.

To this end, the committee sent out a process letter and a reply post card to hospital aid societies asking for their coöperative support and also to a selected list of ladies inviting them to act as patronesses. This letter read as follows:

\section{Dear Madam:}

Realizing the value of pure milk to all hospitals and institutions, the officers and directors of the Philadelphia Milk Show, to be held May 20th to 27th, at 809-813 Chestnut Street, request the honor of using the names of the members of your committee as patronesses of the Philadelphia Milk Show. Your prompt acceptance will be greatly appreciated, as it is the desire of those in charge to publish the names of your committee as indorsing the necessity of pure milk for Philadelphia.

If your board does not meet before May 12th, could you not ask on the telephone the consent of sufficient members to authorize you to permit the use of their names, so that your board can be represented among the patronesses?

$$
\begin{aligned}
& \text { Sincerely yours, } \\
& \text { Mrs. Talcott Wrlliams, } \\
& 916 \text { Pine Street, Philadelphia, } \\
& \text { Chairman, Committee on Patronesses and Aides. }
\end{aligned}
$$

We trust that all patronesses will appreciate the importance of this exhibit to farmers, gardeners, dairymen, cooks, child-nurses, and those entrusted with the care of milk and other foods, restaurant and boarding-house keepers, and employees of soda fountains, etc. It is hoped that a concerted effort will be made to secure their attendance.

During the week of the Show, this committee performed most valuable service in distributing the educational literature at the exhibition rooms. Each day was assigned to the particular charge of one of the patronesses who acted as chairman for the day, and she in turn selected such aides to help as were needed. The duties of the aides consisted in arranging in order sets of ten different leaflets, with a program of the lectures, which were placed within cover folders and handed to all visitors as they came in the entrance. The aides wore badges and a certain number were on hand at all times throughout the week to help with this work. The record, illustrated on the following page, showing the assignments of the different days was prepared on a large chart and was hung up in the literature booth on the first floor which was used exclusively by this committee during the Show. 


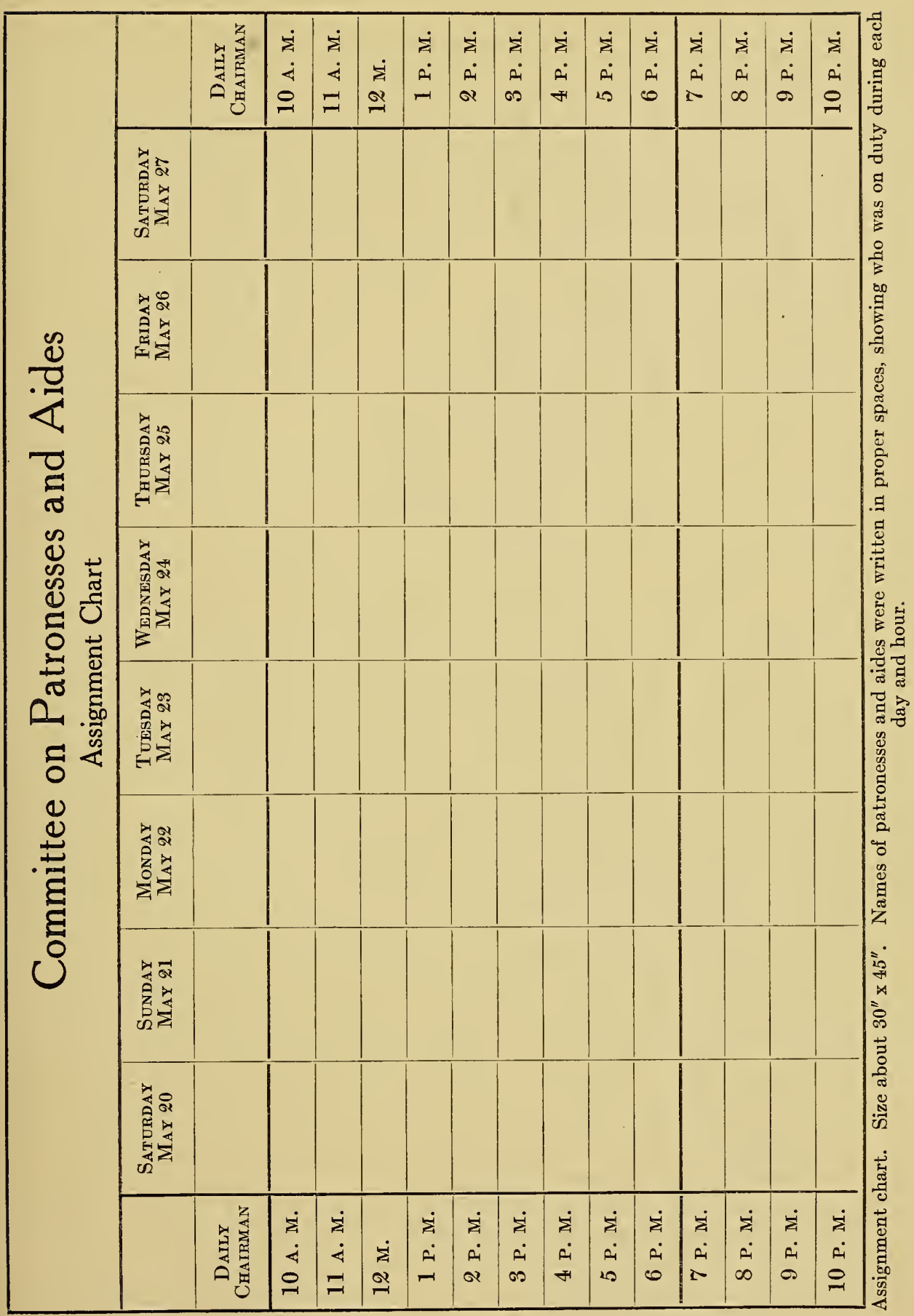



PART THREE

General Description 



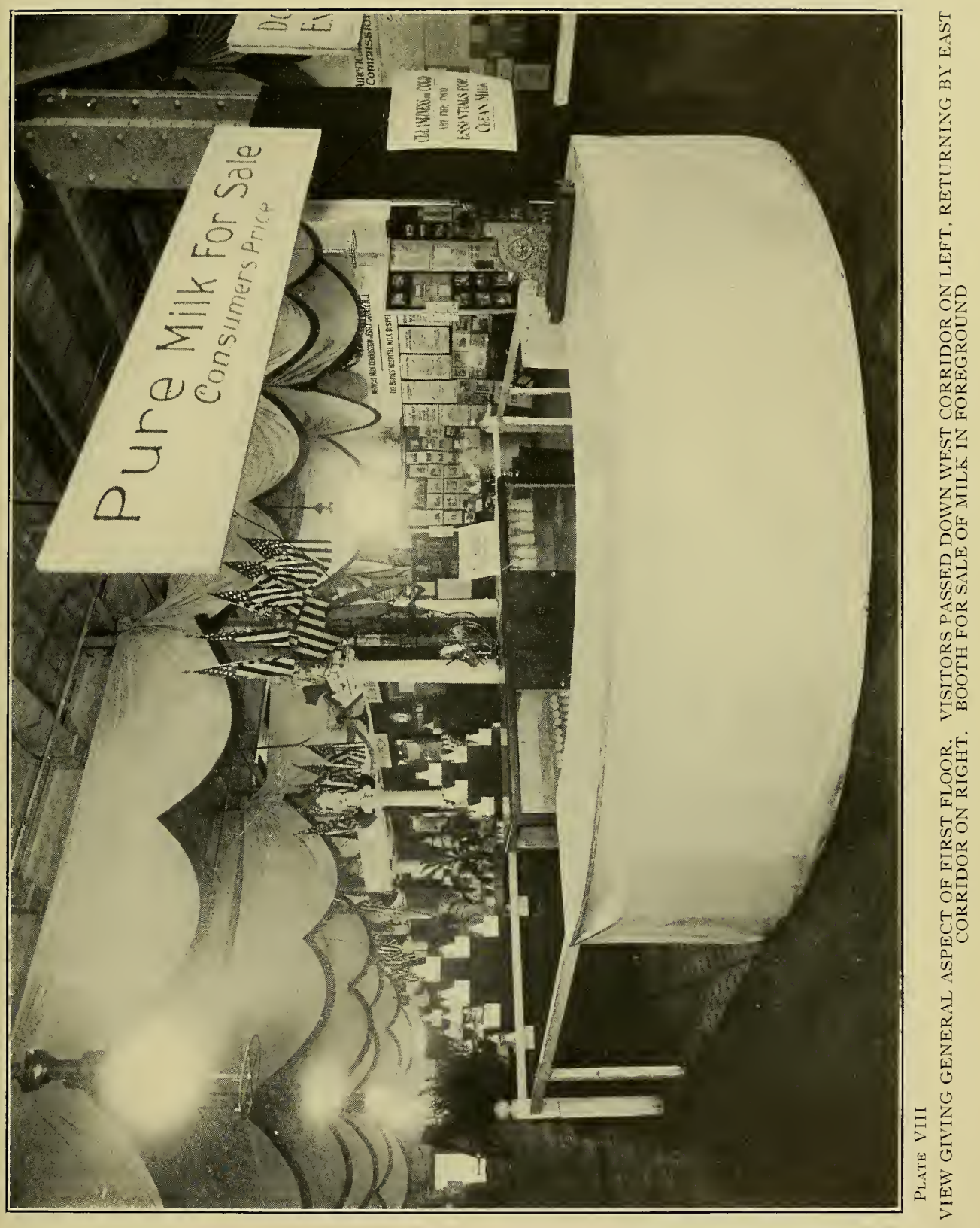





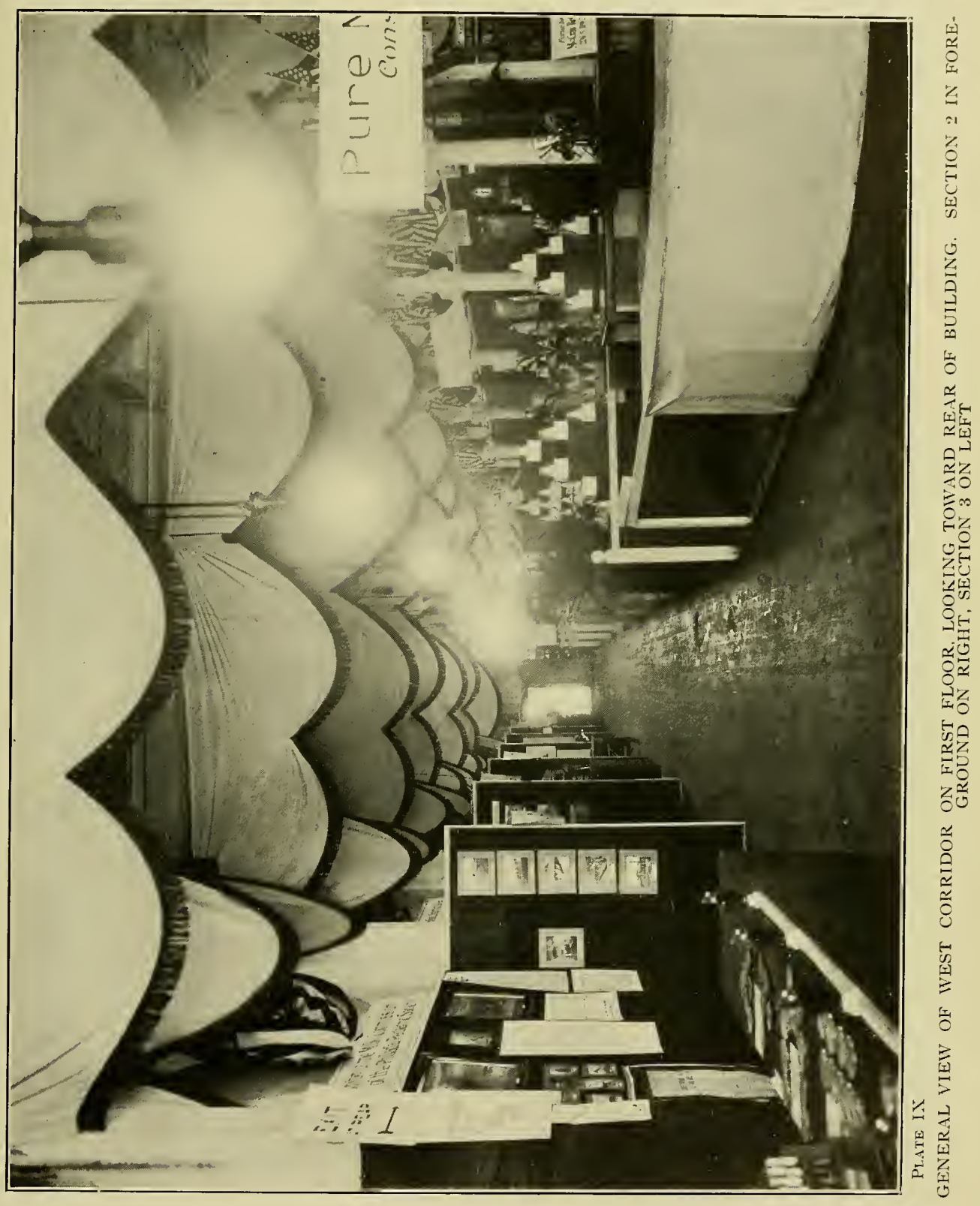





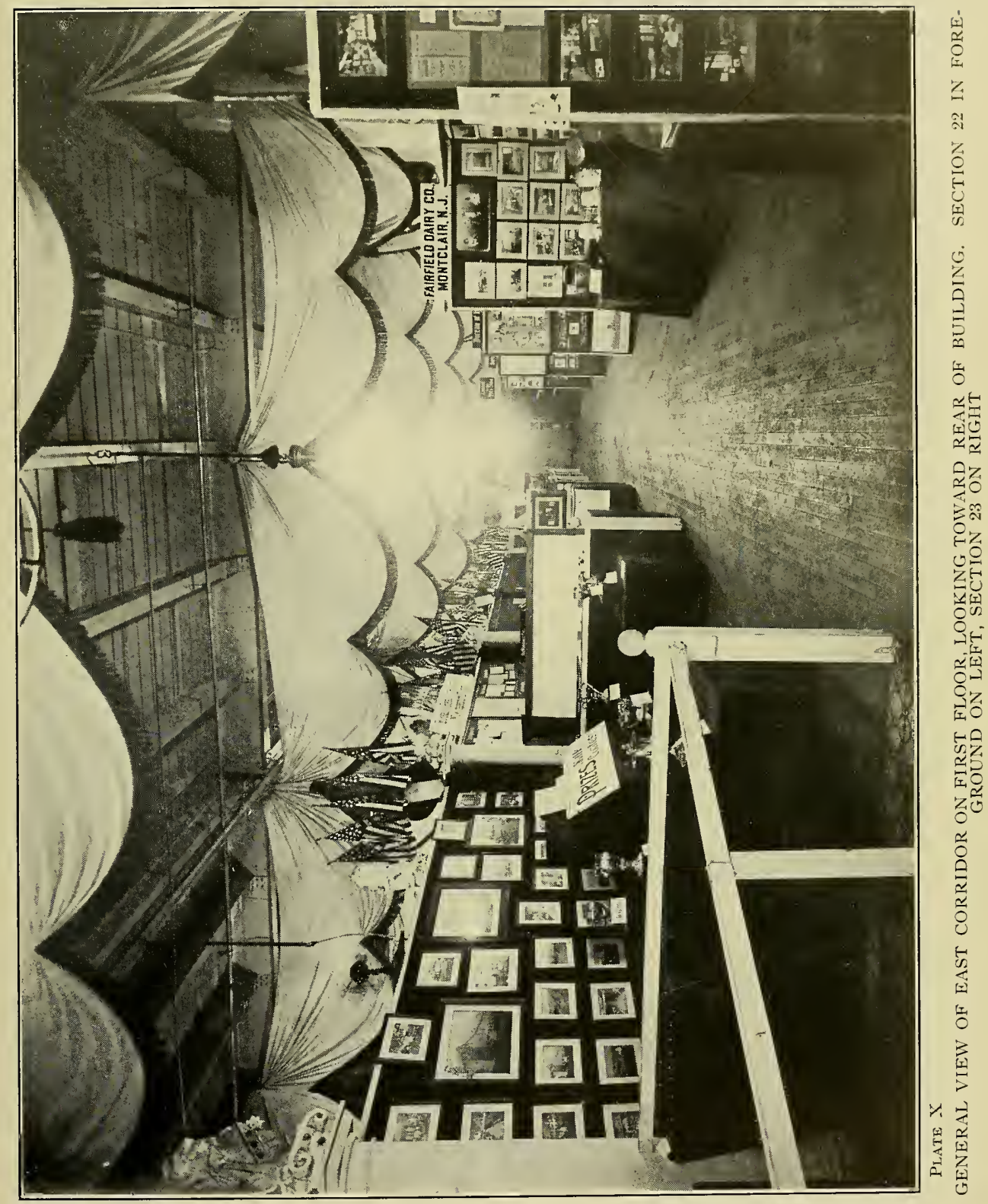



The Oxecutive formmittee ofitio

\section{Shieludelphicu Nlilk Show}

repuests the honoure of nyourforesence

$$
\text { ation }
$$

\section{Private liewrof the Orshilition}

on the afternoon, of Sriday, the mineteon the of Illay

mineternhundred and,eleven

$$
\text { from threeitofive, a dack }
$$

809-811-819tilucetnut firuet 



\section{PART THREE \\ General Description}

\section{Milk Show}

The buildings occupied by the Milk Show were attractively decorated with the national colors and a large sign stretching across the front above the entrance, reading,

\section{THE PHILADELPHIA MILK SHOW To Enlighten-Not To Frighten}

At night, a large electric sign, reading,

\section{MILK SHOW}

was used, showing in both directions on the street. In front of the adjoining lecture hall were signs giving the hours of the lectures and of the moving pictures.

Friday afternoon, May 19th, a private view of the exhibits was held. Approximately nineteen hundred engraved invitations were mailed to all members of City Councils, judges of the courts, principal officials of the different municipal departments, the Philadelphia representatives in the State and National Government, members of Milk Show committees, guarantors, contributors known at the time of mailing, newspaper men, and principals and teachers of the higher grade schools.

On Saturday morning, May 20th, at 10 o'clock, the doors were thrown open to the general public. The exhibit was kept open daily from 10 A. M. until 10 P. M., with the exception of Sunday, when the doors were not opened until 1 P. м. On the following Saturday evening the exhibition closed, after having been visited by over one hundred and ten thousand six hundred persons, the daily attendance being as follows: 


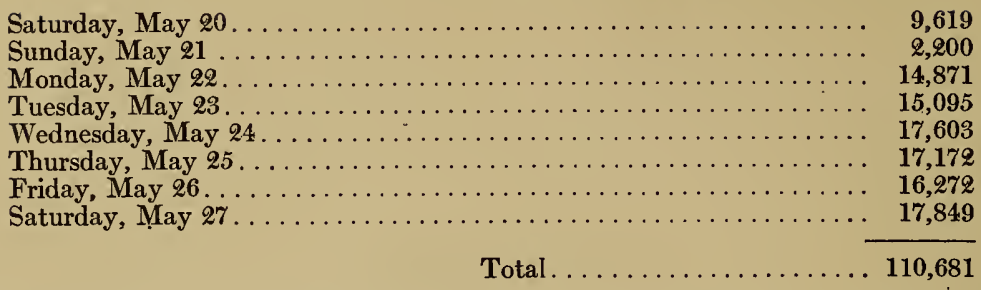

The exhibition was supplemented by free lectures at noon, in the afternoons, and evenings, dealing with various phases of the milk question, and moving picture films on "The Man Who Learned" and "The Fly," which were given at the beginning and the close of each lecture. For subjects and speakers, see complete program in appendix A on p. 84.

Before the lecture and moving picture performance in the adjoining lecture hall, a crier with a megaphone went through the exhibition rooms announcing the subject and the speaker and urging visitors to attend. The lectures and moving pictures were also announced on a bulletin board and several large signs which were placed at conspicuous points.

No figures are available showing the actual attendance at the lectures, but they were well attended notwithstanding the fact that very hot weather prevailed. In fact, the attendance at both the Show and lectures far surpassed the most sanguine expectations. Numerous requests were received asking the executive committee to keep the Show open for a longer period, but this was not thought advisable, since all agreements and contracts, with guarantors, speakers, exhibitors, tradesmen, etc., had been made for the stated period ending May 27th.

\section{Conference of State and Municipal Health Officers}

The sessions of the Conference of Health Officers were not less interesting and instructive. The Philadelphia Record in reporting the Conference says:

Health officials from every section of the country met yesterday at the BellevueStratford and spent the entire day exchanging views as to what can be done to regulate and protect the milk supplies of large cities and discussing the recommendations of the Philadelphia Milk Commission with regard to regulations for this city.

The meeting was held under the auspices of the Philadelphia Department of Public Health and Charities, which desired expressions of opinion from experts from other sections of the country before attempting to embody the report in practical legislation. Copies of the report were sent a month ago to those invited to participate, with the request that they give it their careful consideration, and be prepared to comment upon it at the meeting. An almost unqualified indorsement of the report by the visiting experts was the result, with here and there a doubt as to whether certain proposed regulations could be enforced.

Following the morning session, the delegates were taken in automobiles to the new Municipal Hospital for Contagious Diseases as the guests of the Director of the Department of Public Health and Charities. After an inspection of the 


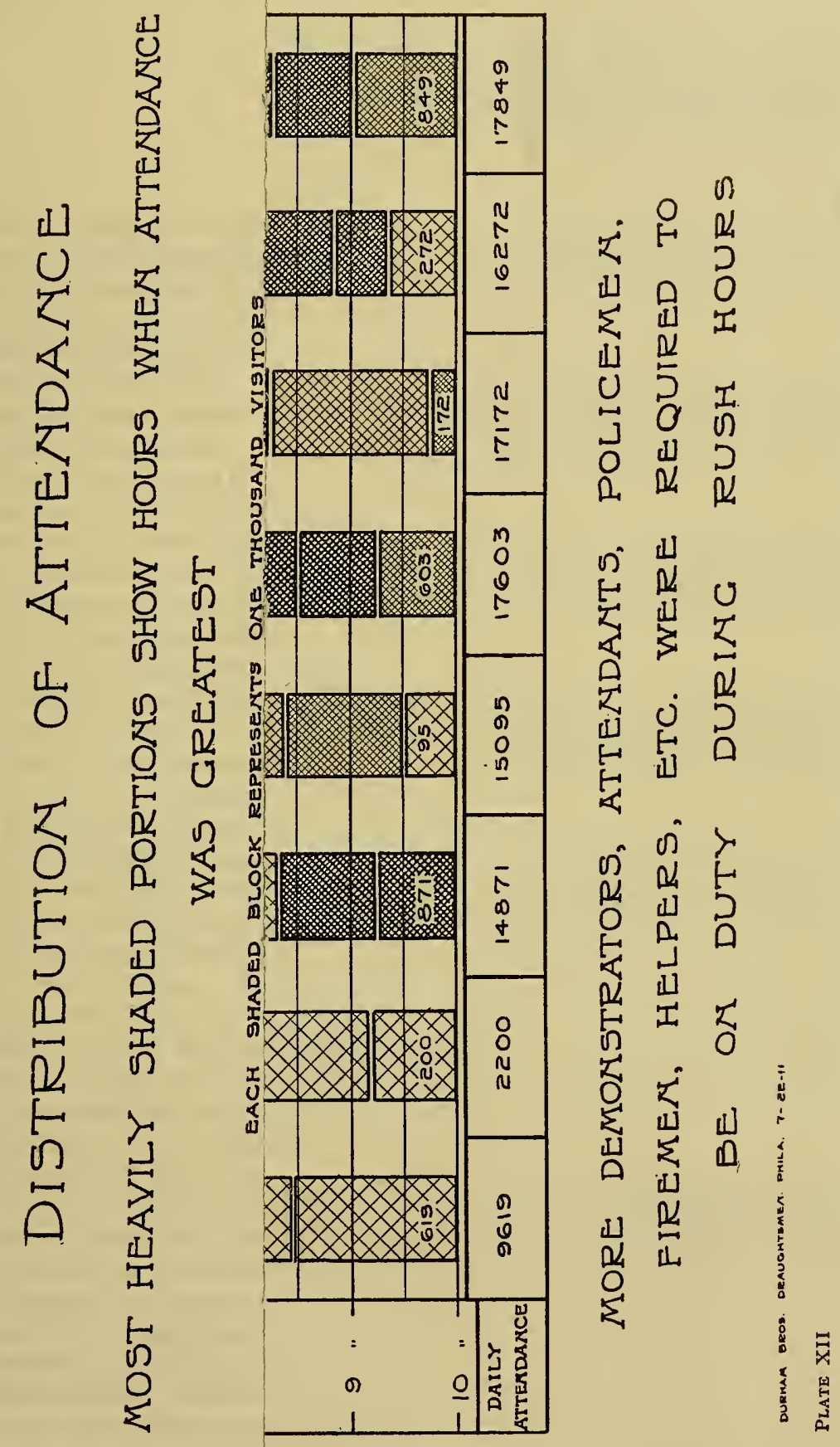





\section{DistRIBUtion OF ATtendance}

MOST HEAVILY SHADED PORTIONS SHOW HOURS WHEM ATTENDANCE WAS GREATEST

EACH SHADED BLOCK REPRESENTS OME THOUSAMD VISITORS

(EXCEPT BOTTOM BLOCK OP EACH DAILY COLUMY WHERE ACTUAL NUMBER IS GIVEN)

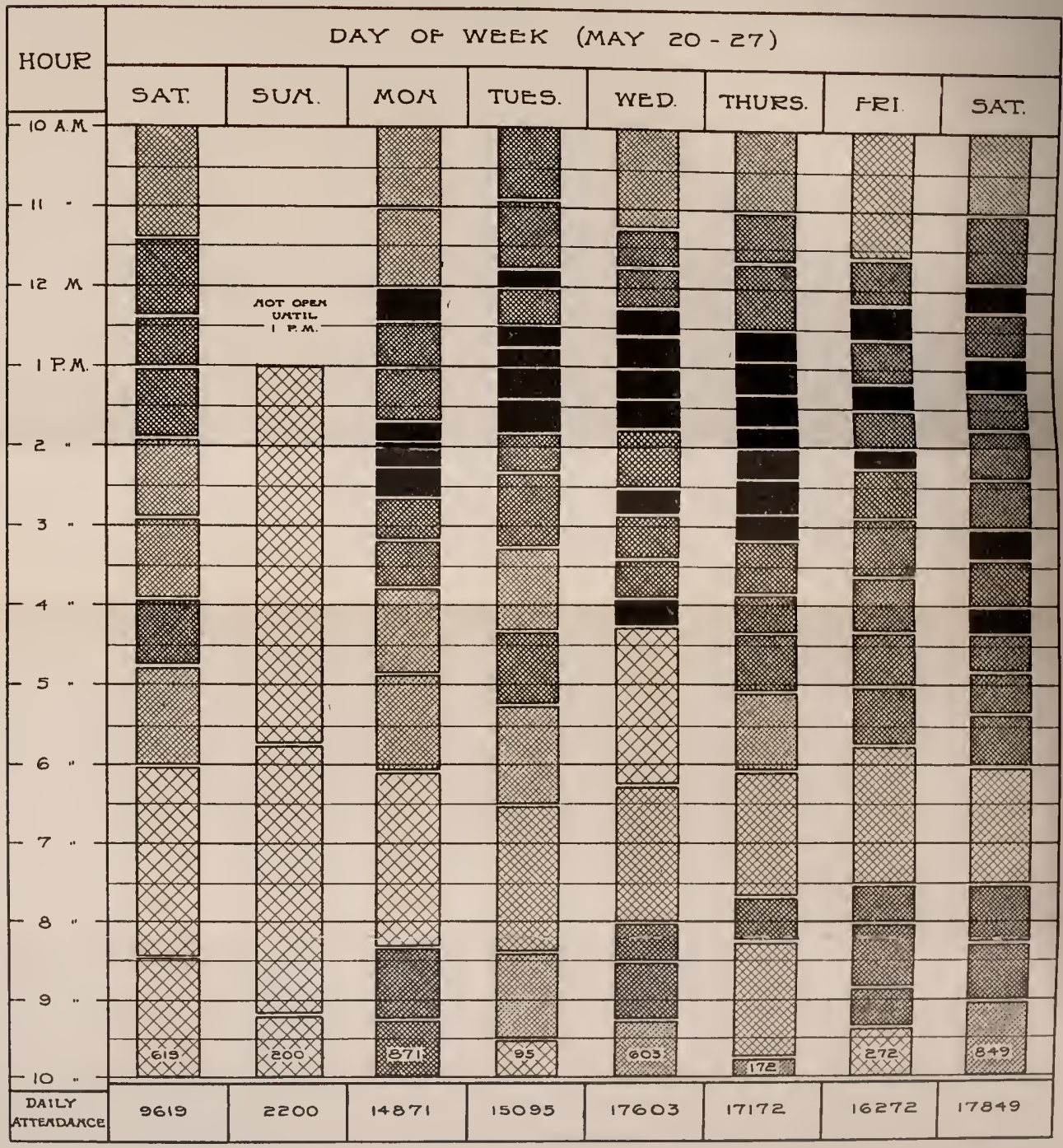

MORE DEMOMSTRATORS, ATTEMDANTS, POLICEME $M$.

FIREMEM, HELPERS, ETC. WERE REQUIRED TO BE ON DUTY DURIMG RUSH HOURS 


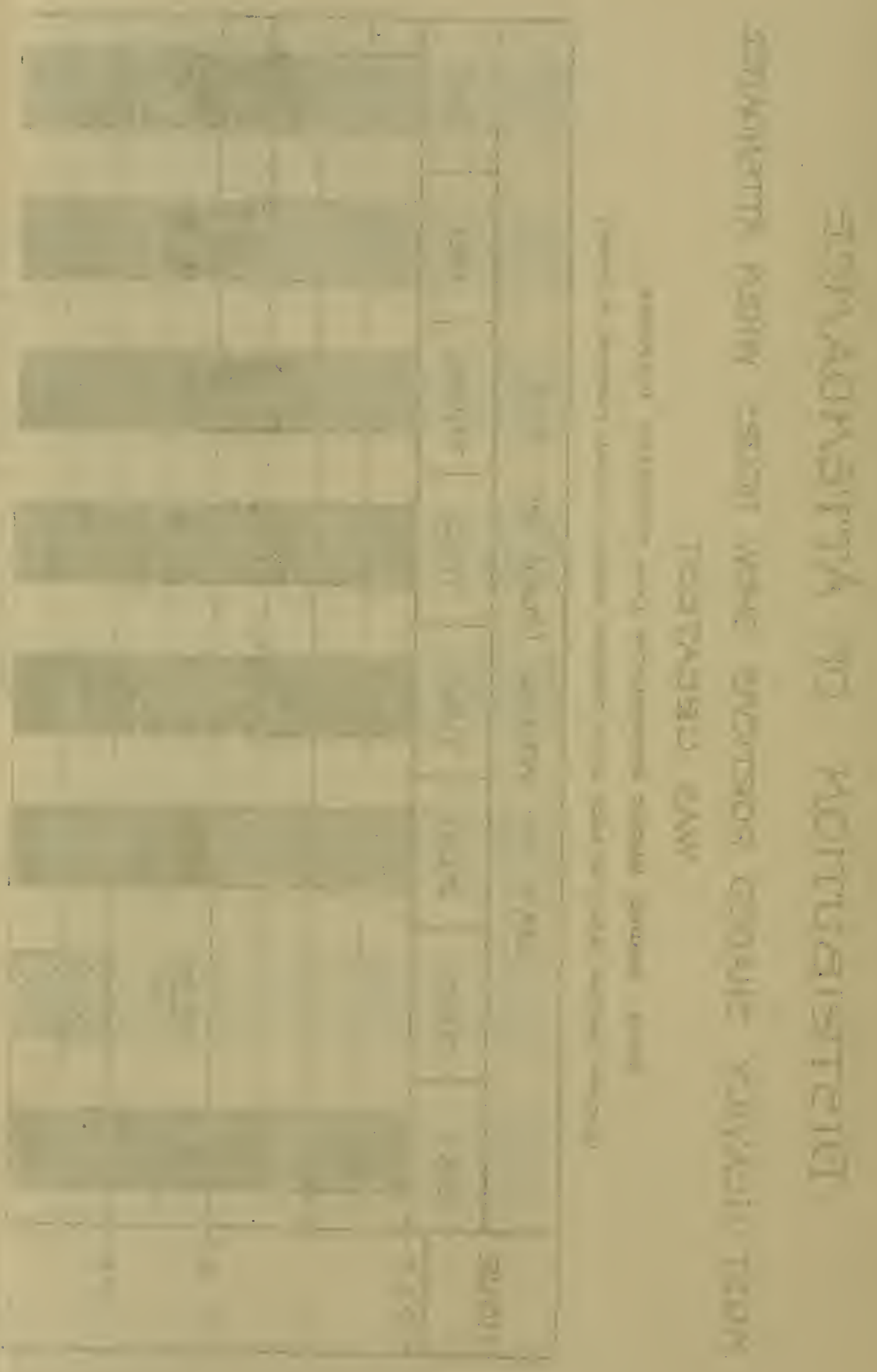


property and explanation of the methods employed, the visitors were entertained at luncheon. The complete program of the Conference is printed as appendix B on p. 87 .

\section{Dairy Institute}

To complete the addresses on the various milk problems incident to a city's milk supply, the Dairy Institute held crowded sessions of great interest and value to the milk producers at the Veterinary School of the University of Pennsylvania. A noteworthy course of lectures was delivered during the three days' sessions by men actively engaged in the subjects discussed. (See list of lectures and speakers in appendix $\mathrm{C}$ on p. 89.) The sessions were held between $10 \mathrm{~A}$. M. and 1 P. M., so that the farmers could visit the Milk Show in the afternoon.

Besides the courses of lectures, much attention was attracted by a unique exhibit in the courtyard showing in a forceful way good and bad dairy stable conditions and a type of inexpensive milk house for use on small dairy farms. The cattle in these stables were brought from farms where conditions prevailed exactly as shown in these reproductions.

To represent the two types of stables an old frame shed was used. This was divided by a partition into two rooms, one of which was freshly whitewashed; no cobwebs or dust appeared on the walls or ceilings; the windows were screened with cheese-cloth for ventilation, and to exclude flies and dust; and a cement floor and gutter were provided.

This room was arranged to allow one thousand cubic feet of air space and eight square feet of window space per cow. It was fitted with comfortable stalls in which clean, healthy cows appeared to be enjoying their inexpensive but sanitary quarters.

In the adjoining room the conditions were such as are found on many of the bad dairy farms which are daily supplying dirty and unwholesome milk to numerous consumers. The walls and ceiling were covered with dust and cobwebs. Overhead a loose floor allowed the dust and chaff to sift down from the hay-mow into the pail while milking. The dirt floor was rough and uneven, covered with soiled litter, and was without gutter for drainage.

The two small windows were totally inadequate to supply sufficient light and ventilation. The cows were crowded together, there being insufficient floor space and air content for the number housed in this small room. The cows appeared uncomfortabie and unhealthy, their flanks and udders being soiled with dried manure, much of which would be dislodged and fall into the pail during milking.

The manure from this stable was thrown just outside the door, forming an ill smelling pile adjacent to the watering trough, in which the milk cans were placed to cool, this being a common practice on farms of this type.

At proper distance from the good stable was placed the milk house, which was constructed of rough lumber, with the doors and windows screened, with cement floor providing good drainage, and equipped with the utensils necessary to care for the milk properly. The interior and exterior of the building were whitewashed and presented a neat, clean and tidy appearance. 
The whole exhibit was inexpensive and was designed to show that clean, wholesome milk can be produced under average conditions without the expenditure of large sums of money.

\section{Milk and Cream Contests}

In connection with the Milk Show there was held a milk and cream contest under the immediate direction of the Dairy Division of the United States Department of Agriculture. Dr. George M. Whitaker, the chief of this division, was judge of awards.

The market milk and cream classes were open to producers sending milk and cream to the Philadelphia market, while the certified milk and cream classes were open to those dairies producing milk and cream under the certification of the commissions which are members of the American Association of Medical Milk Commissions.

Entries for the market milk and market cream contests were received from all parts of the adjacent country and entries of certified milks were forwarded from points as distant as Waukesba, Wisconsin; Genesee Depot, Wisconsin; Toronto, Ontario (2); Glendale, Ohio; and Dixon, California. One of the Wisconsin dairies scored 90 , and the other 91.75 out of a possible 100. The Dixon, California, dairy scored 85.

Through the kindness of the Reading Terminal Market and Cold Storage Warehouse Company, the various samples of milk and cream shipped here for entry in these contests were placed in cold storage free of cost.

Keen interest was taken by producers generally in the award of the prizes for the best samples of milk and cream submitted in the contests. On the afternoon of the closing day of the Show, the prizes were awarded by Doctor Whitaker, who made bacteriological counts of all samples and judged them as to food value, cleanliness and acidity. First and second prizes, consisting of silver cups donated by the Milk Commission of the Philadelphia Pediatric Society, were awarded in each class and all other dairymen whose products scored above 90.00 were awarded diplomas.

The list of awards and point rating follows:

\section{CERTIFIED MILK}

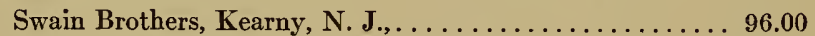

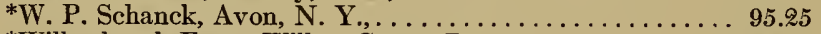

*Willowbrook Farm, Willow Grove, Pa., . . . . . . . . 95.25

Middlebrook Farm, Dover, N. H., . . . . . . . . . . 94.75

Belvidere Dairy, Landenberg, Pa., . . . . . . . . . . 91.90

O. L. Williams, "Wern Farm," Waukesba, Wis., . . . . . . 91.75

Haddon Farms, Haddonfield, N. J., . . . . . . . . . . 91.00

Brook Hill Farm, Genesee Depot, Wis., . . . . . . . . . 90.00
First Prize, Silver Cup

Second Prize, Silver Cup

Diploma

Diploma

Diploma

Diploma

Diploma

Diploma

* Doctor Whitaker reports as follows: In regard to the two contestants in the certified milk class that had the same rating, Willowbrook Farm and W. P. Schanck, of Avon, N. Y., each had a score of 95.25 , but the number of bacteria found in Mr. Schanck's milk was only 400 , while in the Willowbrook Farm's it was 3400; hence, although the final score happened to come out the same, I feel that the Schanck specimen was really a little superior to the other and reported it as taking the second honor, though on the total score it was tied with the Willowbrook Farm. 


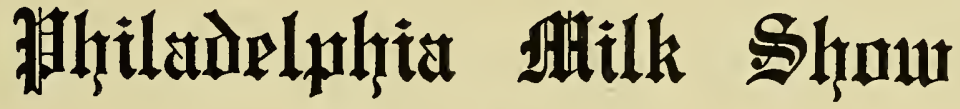

PHILADELPHIA, PENNSYLVANIA

MAY 2 OAs TO $27 \mathrm{~h}, 1911$

\section{MILK AND CREAM CONTEST}

তlyix in to Orrtify that

was awarded this

\section{相iplama}

in the

Class, having enlered a sample of which scored points.

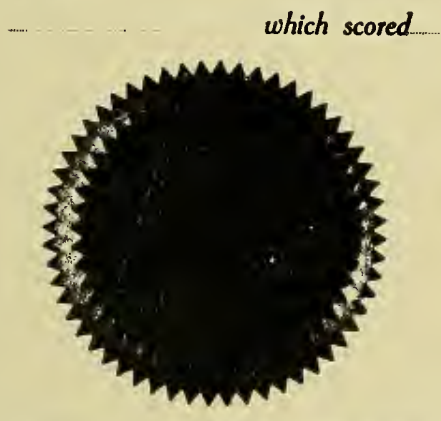

JUDGE OF AWARD

CHALRMAN. COMMITTEE ON DAIRY INSTITUTES
AND MKLK CONTESTS AND JKLK CONTESTS

CHAIRMAN, EXECUTVE COMMTTEE 



\section{CERTIFIED CREAM}

Wawa Dairy Farms, Wawa, Pa.,. . . . . . . . . 90.50

Brook Hill Farm, Genesee Depot, Wis., ........... 88.00

\section{MARKET MILK}

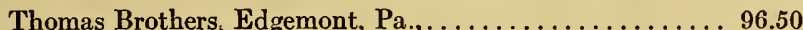

Isaac Rohrer, Gordonville, Pa., . . . . . . . . . . . 96.00

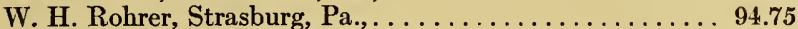

John R. Kendig, Pomeroy, Pa., . . . . . . . . . . 94.65

William H. Jones, Upper Darby, Pa., . . . . . . . . . . 92.50

David Wilson, New Centreville, Pa., . . . . . . . . 91.50

George R. North, Lyndell, Pa., . . . . . . . . . . 91.50

\section{MARKET CREAM}

David Wilson, New Centreville, Pa., . . . . . . . . 90.75

J. C. Nolan, Mt. Airy, Pa.,................ 78.50

First Prize, Silver Cup Second Prize, Silver Cup

First Prize, Silver Cup Second Prize, Silver Cup Diploma

Diploma

Diploma

Diploma

Diploma

The average score of all the dairies entering samples in the four classes was 85.26, which, considering the time of year and the very hot weather, was judged by Doctor Whitaker as remarkably good. Of particular interest, in connection with the result, was the fact that the highest score was made by a sample of market milk, and that another sample of market milk was equal to the highest score reached by the certified milks. 

PART FOUR

Detailed Description of Exhibits 



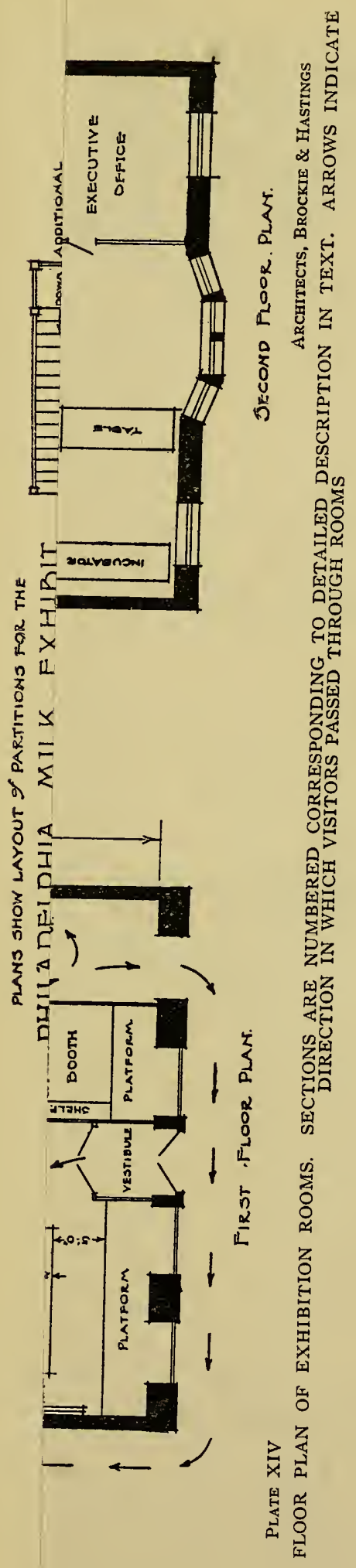




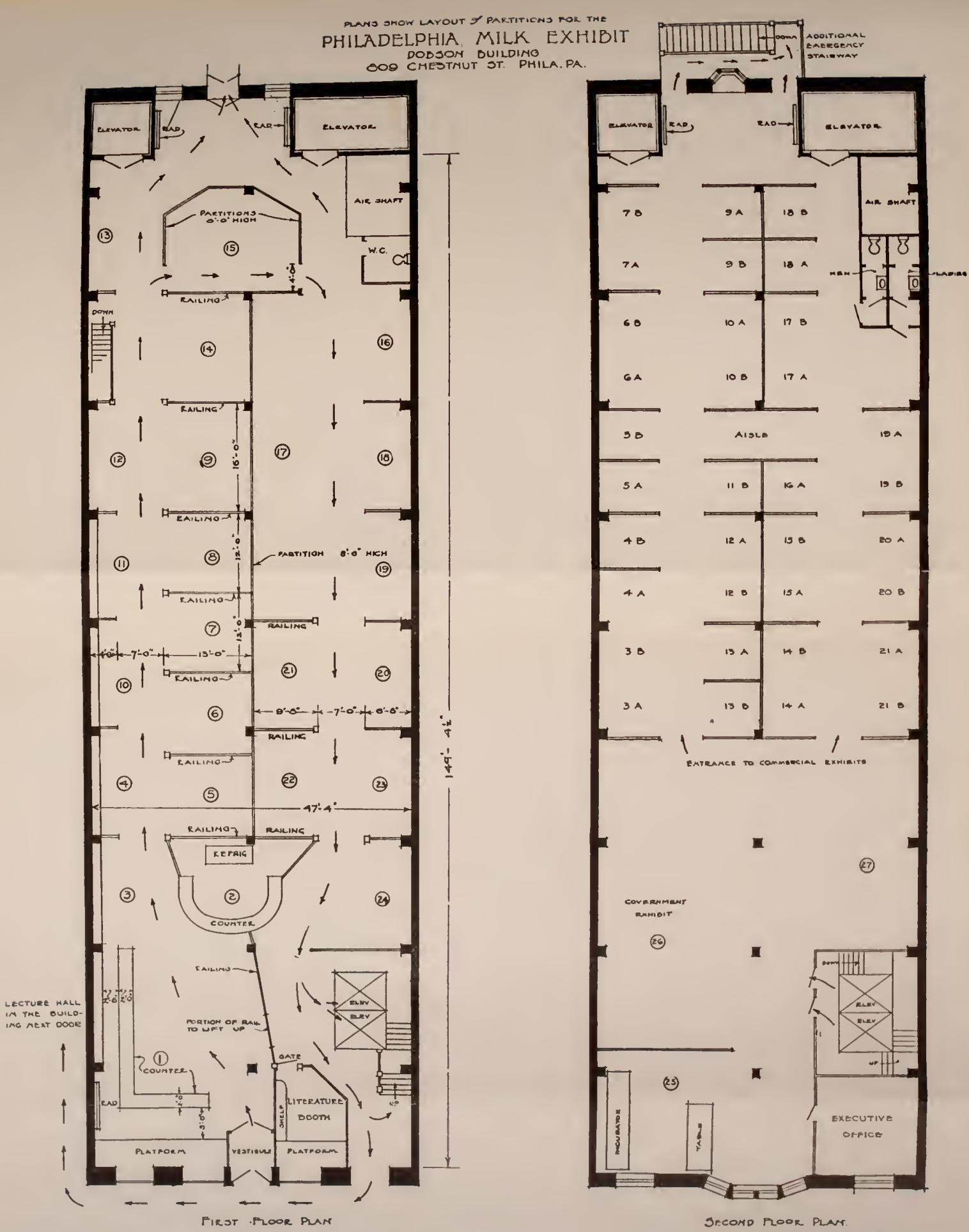


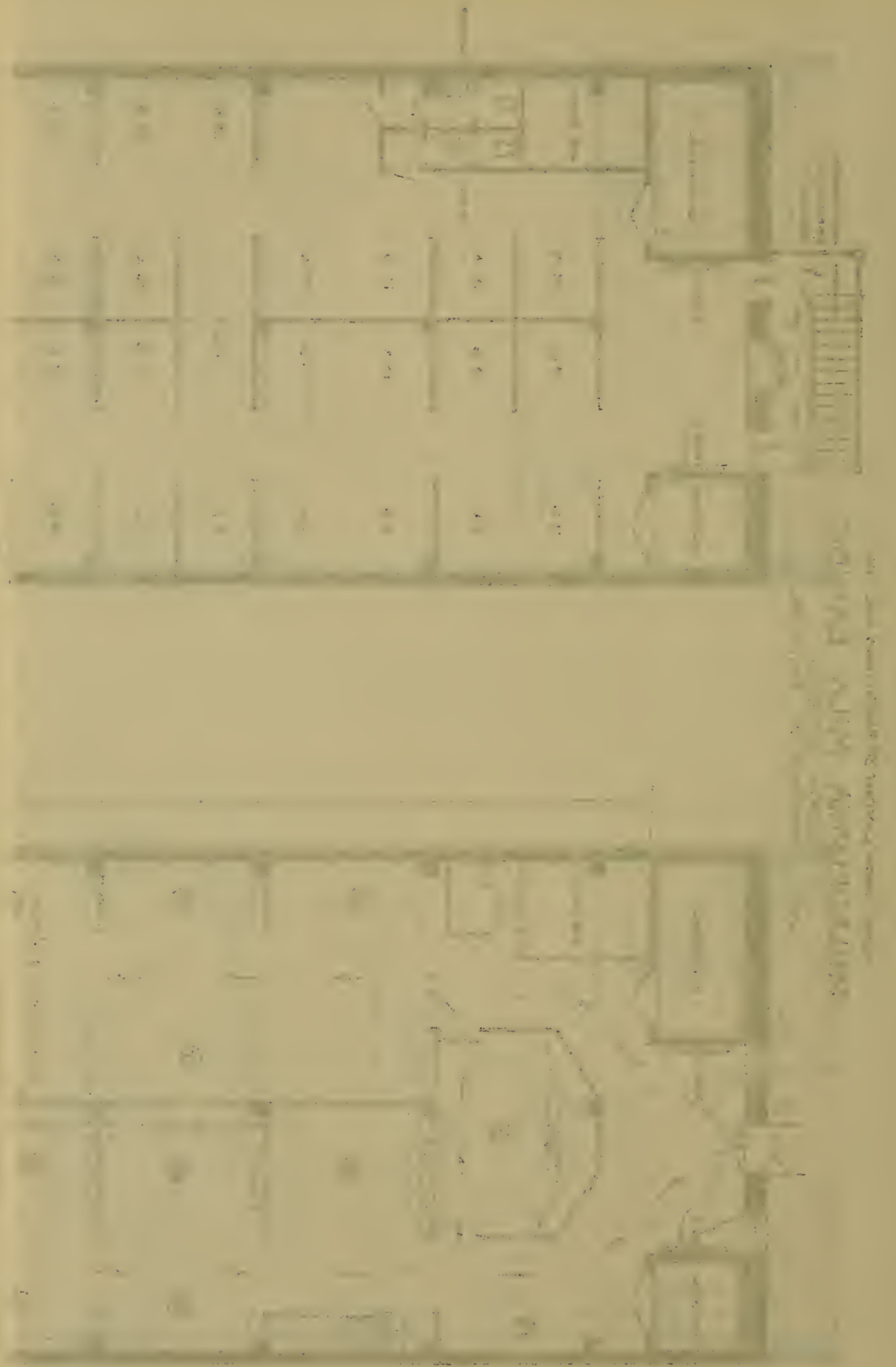


Out of 1000 Births, the following number of Children will die in their FIRST YEAR in the various countries forming the CIVILIZED WORLD

Compiled from the averages for 10 Years

\begin{tabular}{|c|c|c|}
\hline COUNTRY & $\begin{array}{l}\text { DEATHS } \\
\text { UDERIVEAR TC } \\
1000 \text { BIRTHS }\end{array}$ & $\begin{array}{l}\text { DEATHS } \\
\text { O UNOER IYEAR } \\
\text { ACTUA RUMBE }\end{array}$ \\
\hline $\begin{array}{l}\text { CHILI } \\
\text { RUSSIA (EUROPEAN) } \\
\text { AUSTRIA } \\
\text { ROUMANIA } \\
\text { HUNGARY } \\
\text { GERMAN EMPIRE } \\
\text { JAMAICA } \\
\text { CEYLON } \\
\text { SPAIN } \\
\text { UNITED STATES }\end{array}$ & $\begin{array}{l}326 \\
263 \\
222 \\
218 \\
212 \\
197 \\
181 \\
179 \\
170.0 \\
165\end{array}$ & $\begin{array}{r}30.303 \\
1.298 .245 \\
200.553 \\
49.589 \\
154.100 \\
374.153 \\
6.414 \\
23.255 \\
106.649 \\
280.000 \\
2 ., 0 P P O x\end{array}$ \\
\hline $\begin{array}{l}\text { ITTALY APPPOXIMATED: } \\
\text { ITALY }\end{array}$ & 161 & $\begin{array}{l}83.970 \\
83.9 P 0 x\end{array}$ \\
\hline & & \\
\hline & 153 & 16. \\
\hline $\begin{array}{l}\text { FRAN } \\
\text { BULG }\end{array}$ & $\begin{array}{l}148 \\
144\end{array}$ & $\begin{array}{r}115.378 \\
23.757\end{array}$ \\
\hline & $\begin{array}{l}140 \\
139\end{array}$ & $\begin{array}{r}8.200 \\
147.660\end{array}$ \\
\hline Sw/r & 138 & 11.441 \\
\hline $\begin{array}{l}\text { HOLLA } \\
\text { FINLA }\end{array}$ & & \\
\hline $\begin{array}{l}\text { FINL } \\
\text { WESI }\end{array}$ & & \\
\hline & $\begin{array}{r}124 \\
95\end{array}$ & \\
\hline & 98 & \\
\hline & 96 & $11.9 / 2$ \\
\hline & 9 & \\
\hline & 93 & \\
\hline $\begin{array}{l}\text { SOUTH AUSTRALIA } \\
\text { NORWAY }\end{array}$ & $\begin{array}{l}93 \\
86\end{array}$ & \\
\hline NEW ZEALAND & 76 & 2.233 \\
\hline
\end{tabular}

GRAND TOTAL 3243.958

This Means A Baby Dies

In The Civilized World

Every 10 Seconds.

WATCH THE LIGHTFLASH!

Plate XV

Street Show Window on Right of Entrance RED ELECTRIC LIGHT FLASHING TO SHOW INFANT DEATH RATE AND CHART GIVING INFANT MORTALITY STATISTICS 


\section{PART FOUR . \\ Detailed Description of Exhibits}

\section{Educational Exhibits}

A fair idea of the various exhibits may be secured by reference to the floor plans (see plate on opposite page) together with the various illustrations of each booth or section and the detailed explanation which follows. In the floor plans each booth or section is numbered, and in this explanation the various sections are described in the order in which a visitor would see them; that is, going down one aisle and up the next.

\section{FIRST FLOOR EXHIBITS}

Street Show Window on Right of Entrance-Plate XV Exhibit of the American Association for the Study and Prevention of Infant Mortality, Baltimore, Maryland

In this window were displayed two charts, one of which contained a red electric light which flashed every time a baby died in the civilized world, or every ten seconds. This chart attracted a great deal of attention and was one of the best advertisements of the Show. The second chart was one giving infant mortality statistics.

\section{Street Show Window on Left of Entrance}

Exhibit of the Bacteriological and Chemical Laboratories of the Philadelphia Department of Public Health and Charities

This window contained several pieces of apparatus used in the bacteriological and chemical laboratories in testing milk and a poster calling attention to flies as carriers of disease:

\section{FLY TIME}

If it takes one fly three hours to contaminate the sterilized milk in Jar A, and twelve flies fifteen minutes to contaminate the sterilized milk in Jar B, how long will it take you to kill all the flies in your home? Daily at 3 o'clock the results of the contamination will be shown (moving pictures) 
Upon entering the first floor, one passed two attendants at the entrance, usually a fireman and policeman being on duty. Either the fireman or an attendant counted all persons who entered, a counting device held in the hand recording the total each time it was pressed. No children were admitted unless accompanied by adults. Except at those hours of the day when the attendance was slight, the visitors were kept moving in one direction only, entering by one door and leaving by another.

At the right of the entrance was located the literature booth, equipped with a counter, which was used by the committee on patronesses and aides in distributing the programs and educational leaflets:

\section{PROGRAMS}

1. Daily lectures in lecture hall

2. Sessions of Dairy Institute

3. Sessions of Conference of Health Officers

\section{LEAFLETS}

1. Good and bad dairy farms

2. The transportation and sale of milk

3. The care of milk in the home

4. The food value of milk

5. Diseases caused by impure milk

6. Suggestions for bottle-fed babies

7. Milk "Don'ts"

8. Refreshing milk drinks

9. A milk primer

10. List of United States government publications about milk

(See reprints of programs and leaflets in appendices in back of this report)

\section{Section I-Plates XVI and XVII}

(Refer to floor plan, opposite p. 52)

Exhibit of the Bacteriological and Chemical Laboratories of the Philadelphia Department of Public Health and Charities

This exhibit consisted of two main divisions:

1. A counter exhibit showing the physical, chemical, and bacteriological tests used by the Bureau of Health in its inspection of the milk supply.

2. A wall exhibit consisting of:

1. Colored diagrams showing microscopically the various bacteria found in milk: tubercle, typhoid and diphtheria bacilli, streptococci, pus cells, and dirty milk.

2. Charts showing the rise in the death-rate from intestinal diseases in summer and the proportion of deaths of breast-fed and bottle-fed infants.

3. Charts showing typhoid epidemics in two city blocks due to infected milk shops.

4. Posters showing the relation between infected milk and epidemics of typhoid, scarlet fever, and diphtheria.

The usefulness and effectiveness of this exhibit were in great measure due to the efficiency of the attendants, who were able to present very simply the technical processes of milk examination and to make clear the lessons of the charts and posters.

The laboratory apparatus used in the testing of milk was arranged on the counter, and in explaining the exhibit attention was directed: 


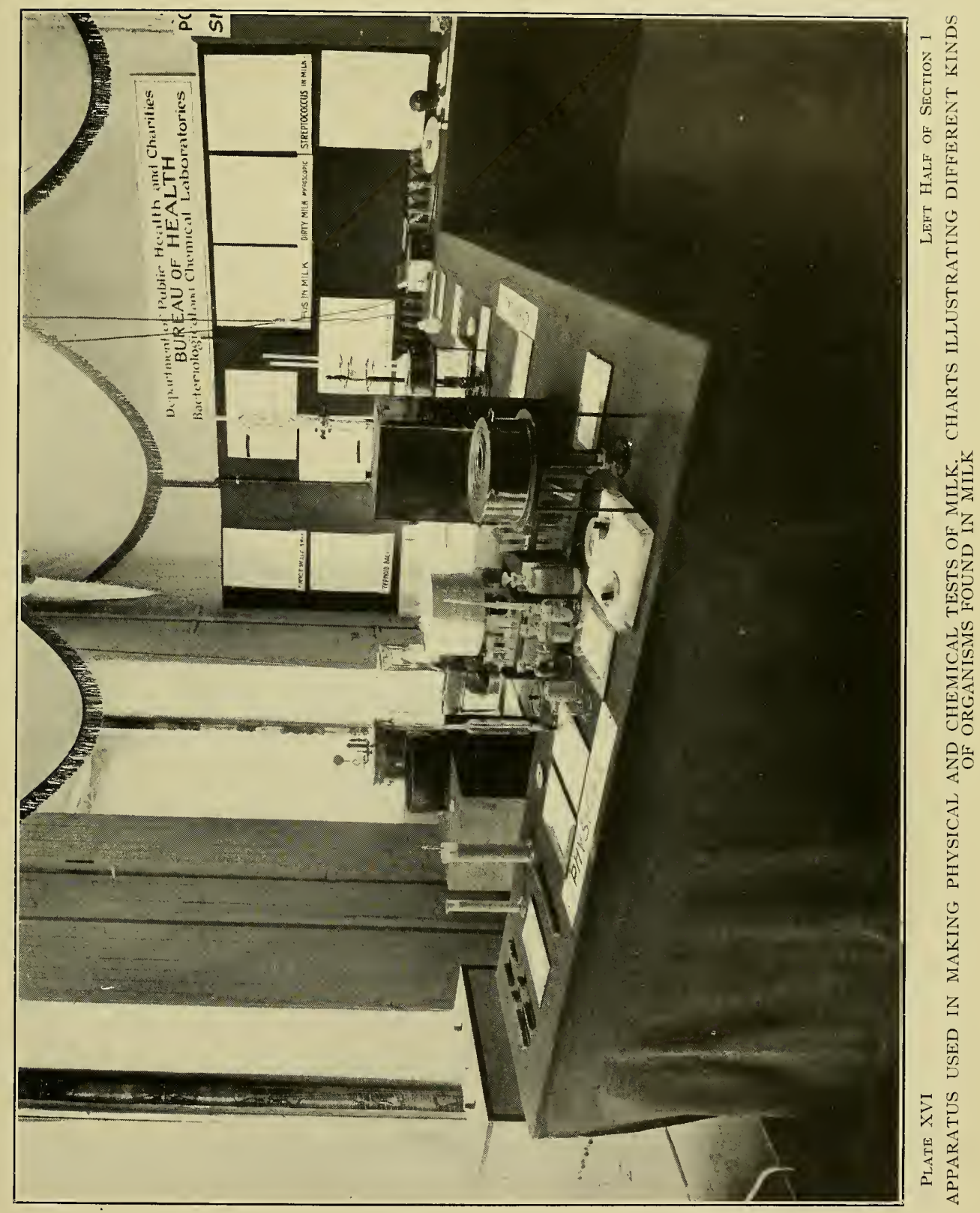





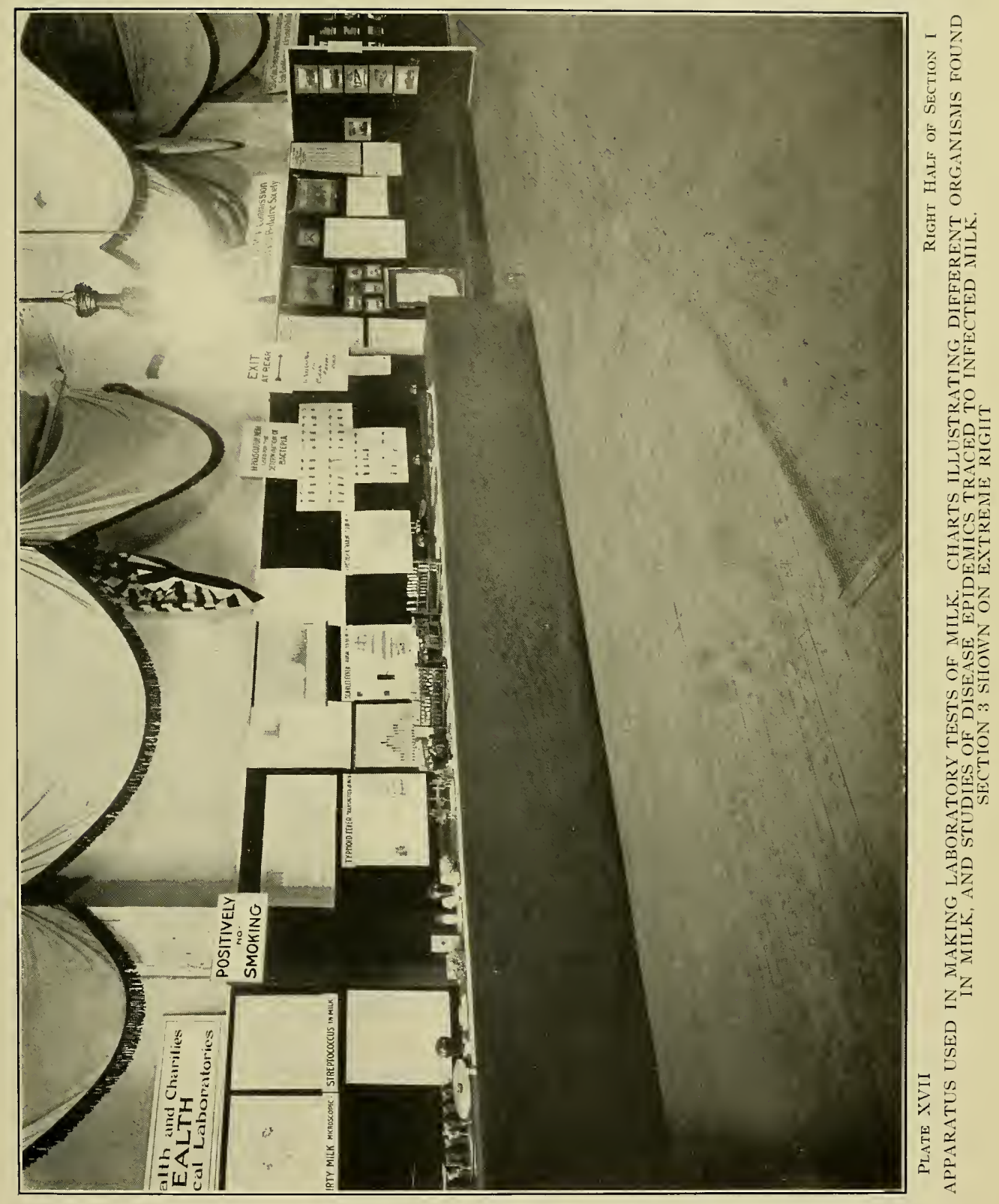



First-to the physical tests made by the milk inspectors at the railroad receiving platforms to determine the specific gravity and the presence of formaldehyde.

Second-to the tests made at the laboratories in the City Hall, of the samples of milk sent in by the inspectors:
1. Microscopic test for dirt
2. Tests for pus cells and streptococei
3. Bacteriological count

Third-to microscopic slides showing:

1. Effect of insects walking on culture media,-the house fly, roach and ant

2. Bacteria on cow hair and the effect when dropped into milk

3. Effect of hands in milking,-clean, dirty

4. Effect of clean and dirty utensils and barns

Fourth-to the charts and posters.

Two very effective charts showed outlines of city wards in which epidemics of typhoid fever had occurred. The typhoid fever cases were indicated by dots in black. The milk shop to which the milk supply of these cases was traced was represented by a red dot. The lettering on the charts was as follows:

1. A milk-borne typhoid epidemic in the Twenty-first Ward, Philadelphia. Infection was found to be from two unreported cases at the milk shop shown, which was closed, premises cleaned, and disinfected. The cases from this ward then became normal.

2. A milk-borne typhoid epidemic in the Twenty-sixth Ward, Philadelphia. Infection was found to be from two unreported cases in the milkman's family and further traced to five unreported cases in the family of a shipper. Stopping this reduced the cases for this ward to normal.

The posters showed in pictorial form a typhoid epidemic traced to the use of contaminated spring-water in washing milk cans; a scarlet fever epidemic traced to the milk supply from a farmer whose child had the disease; and a diphtheria epidemic traced to the boy who washed the milk cans.

There was also shown a collection of test tubes containing various culture media used for the culture of bacteria.

\section{Section 2-Plate VIII \\ Refreshment Counter}

Certified milk was sold here in original packages in one-half pint bottles for five cents; no milk, however, being sold on Sunday. This section was equipped with a semicircular counter, and a large ten-foot refrigerator loaned by the McCray Refrigerator Company for keeping the supply. Sanitary paper drinking cups were used exclusively. Much of the milk sold here was donated to the Milk Show by Mr. P. P. Gheen, Overlook Farms, Willow Grove, Pennsylvania; Mr. E. T. Gill, Haddon Farms, Haddonfield, New Jersey; Mr. Clarence Kates, Glenloch, Pennsylvania; Mr. George Wood, Wawa Dairy Farms, Wawa, Pennsylvania; and Mr. H. H. Jeffries, Landenberg, Pennsylvania. Abbott's Alderney Dairies contributed the services of the waitresses who dispensed this nourishing refreshment. So popular was the sale of this milk that at times the demand exceeded the supply. 


\section{Section 3-Puate XVIII}

\section{Exhibit of the Milk Commission of the Philadelphia Pediatric Society}

1. Photographs of the interior and exterior of model dairy farms producing certified milk.

2. Chart showing the bacterial content per cubic centimeter of milk and cream examined for the Philadelphia Pediatric Society's Milk Commission for the year 1910 .

3. Chart showing a glass of milk and its food value compared to ordinary portions of other food.

4. Charts comparing the number of cases of tuberculosis caused by the human type of tubercle bacillus with those caused by drinking milk from tubercular cows.

\section{Section 4-Plate XIX}

Exhibit Showing Collection, Transportation, and Sale Conditions of Milk In and Around Philadelphia

This exhibit consisted of photographs showing the following existing conditions:

Good, clean looking herd of cattle (two photographs)

Clean stable with yard in fair condition

Milking time

Good stable interior (two photographs)

Fair stable interior (three photographs)

Bad stable interior (six photographs)

Dirty cow shed exterior (two photographs)

Healthy cows in filthy surroundings

Tumbledown barn (two photographs)

Open sewage from barn

Open sewage from dirty cow sheds

Dirty storage room for bottling milk

Cooling milk

Milk cans on shipping platform

Milk train

Old refrigerator car

New refrigerator car

Trolley milk car exterior

Trolley milk car interior

Milk receiving station

Milk wagons at receiving station

Testing milk

Milk wagons (two photographs)

Cooling and pasteurizing plant (three photographs)

Model cooling and pasteurizing plant (two photographs)

Delivery in bottles

Dirty bottles

Dirty milk store (three photographs)

Fair milk store

Clean milk store

Ice cream vendor

Filthy ice cream plant (two photographs)

\section{Section 5-Plate XX \\ Exhibit of Certified Milk}

This section was devoted to an exhibit of certified milk in sealed bottles from the Willow Grove Dairy. The bottles were arranged in pyramids, being placed in long tin boxes and surrounded with ice. Potted plants added to the general attractiveness of this booth. 


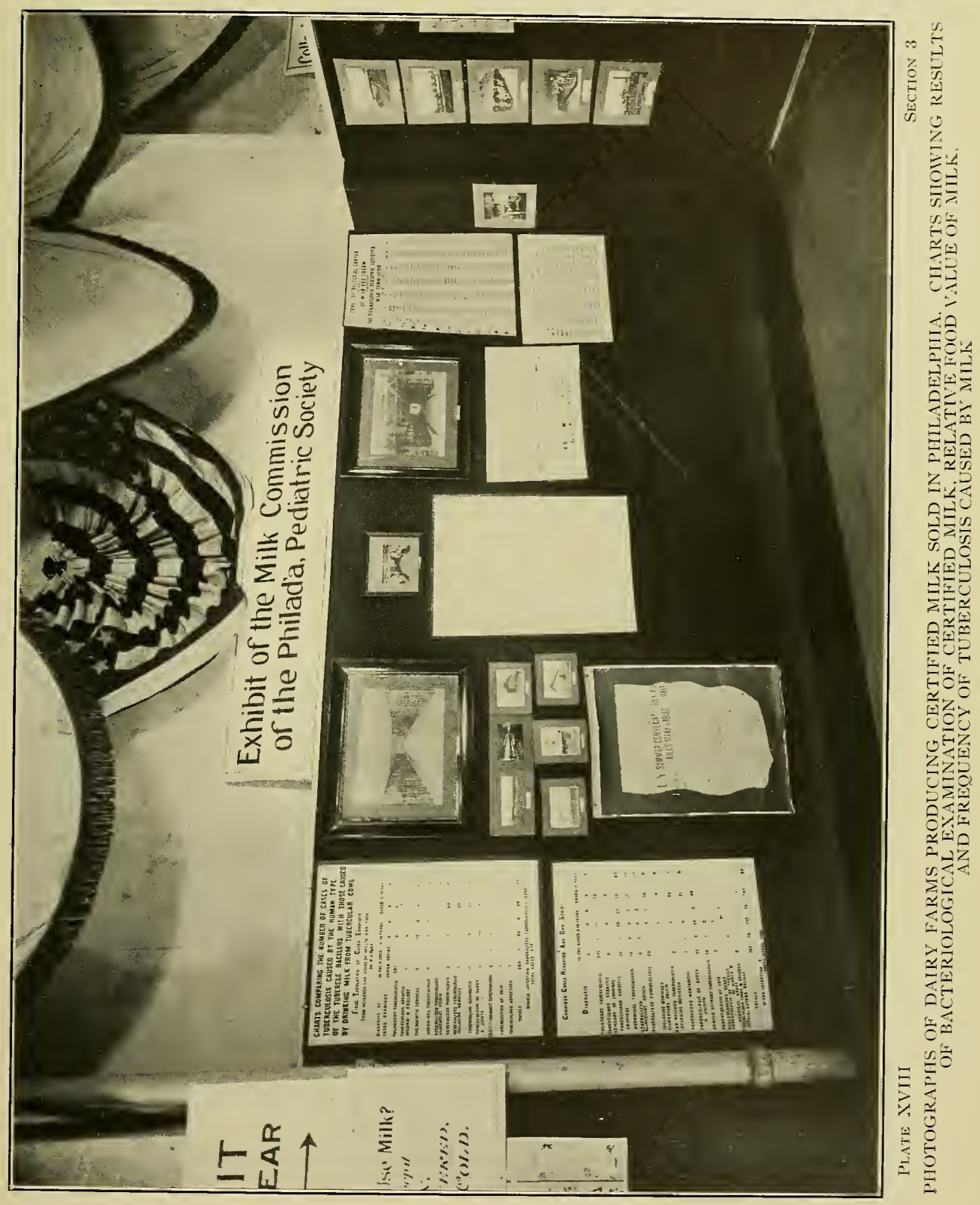





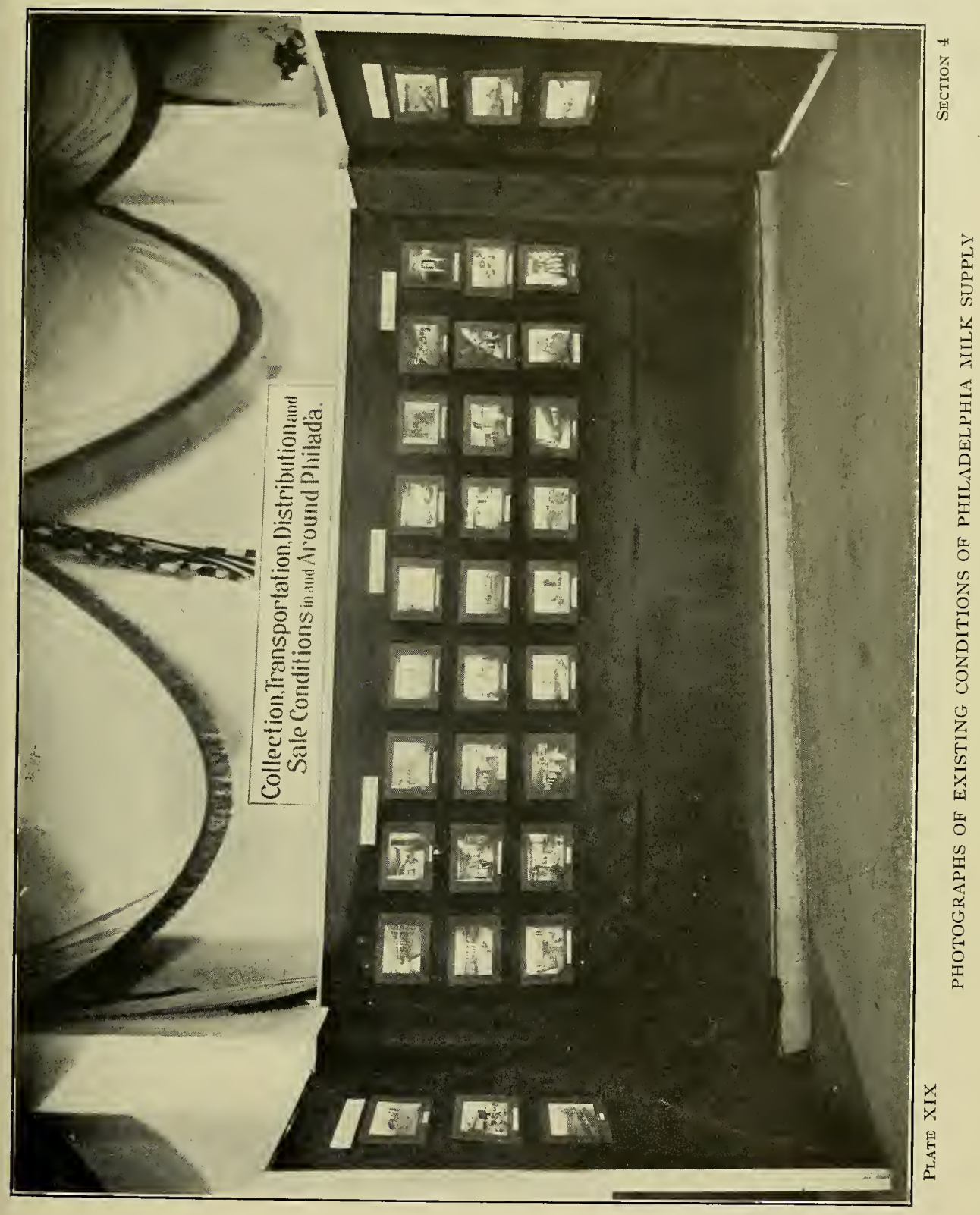





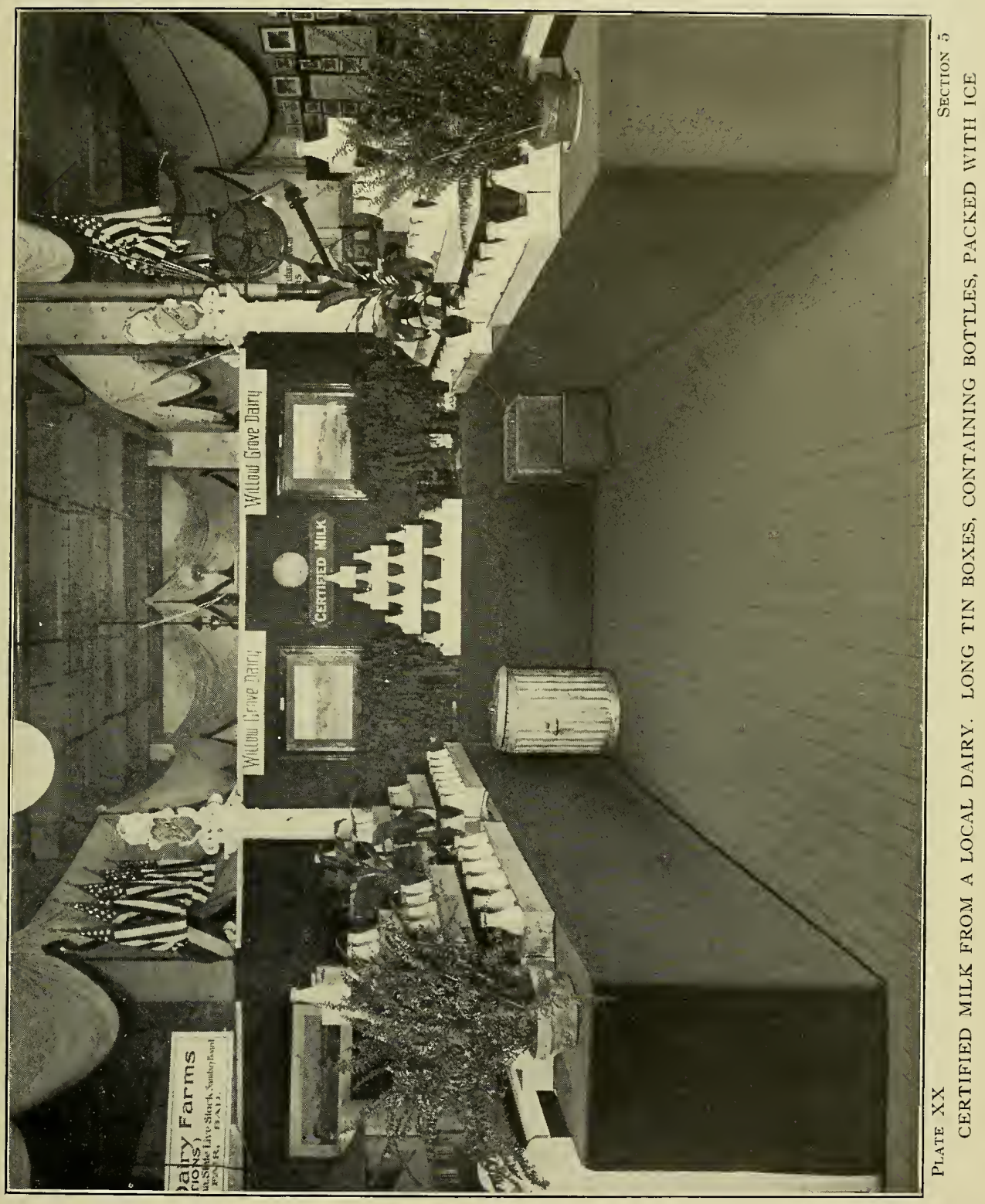





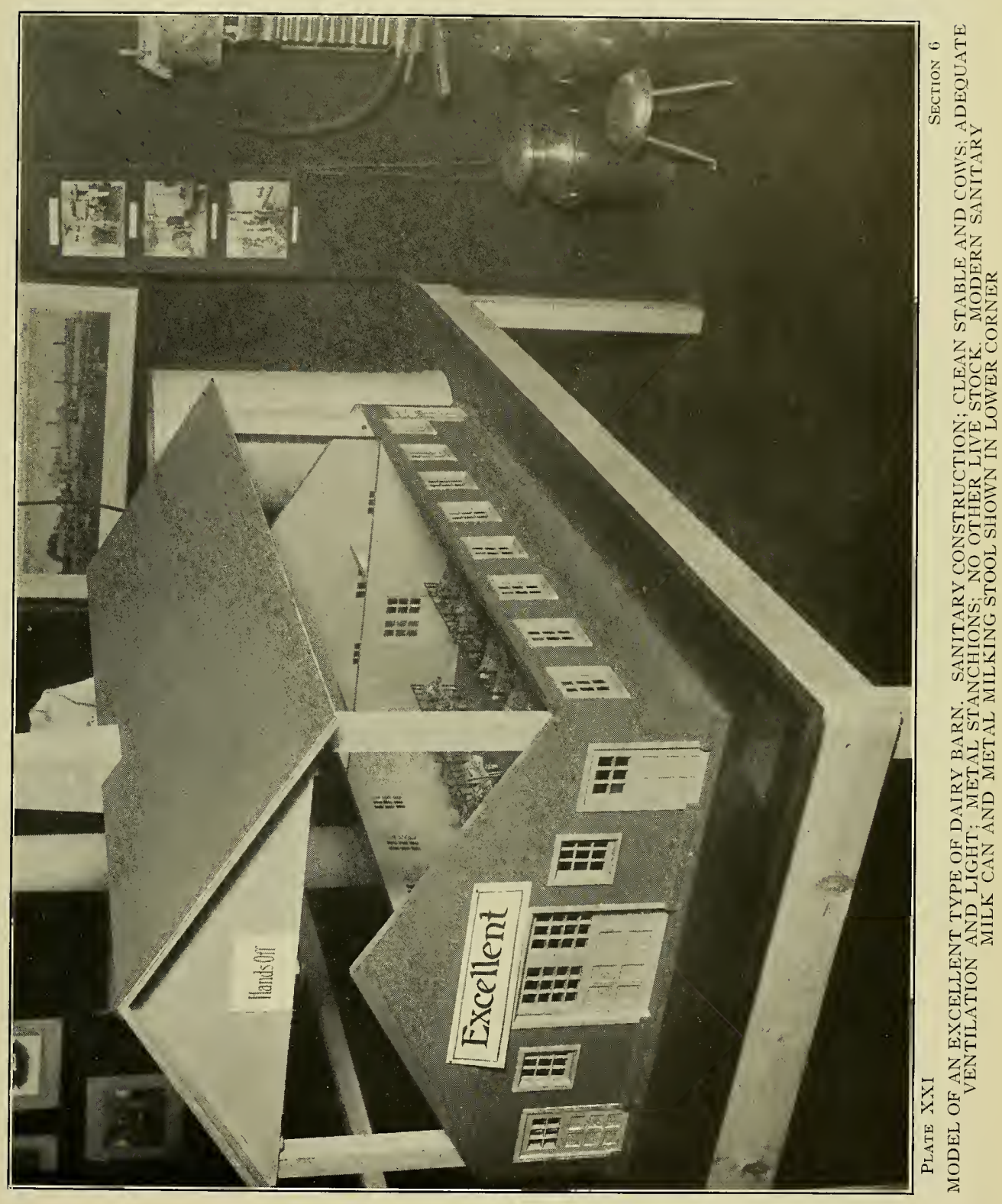





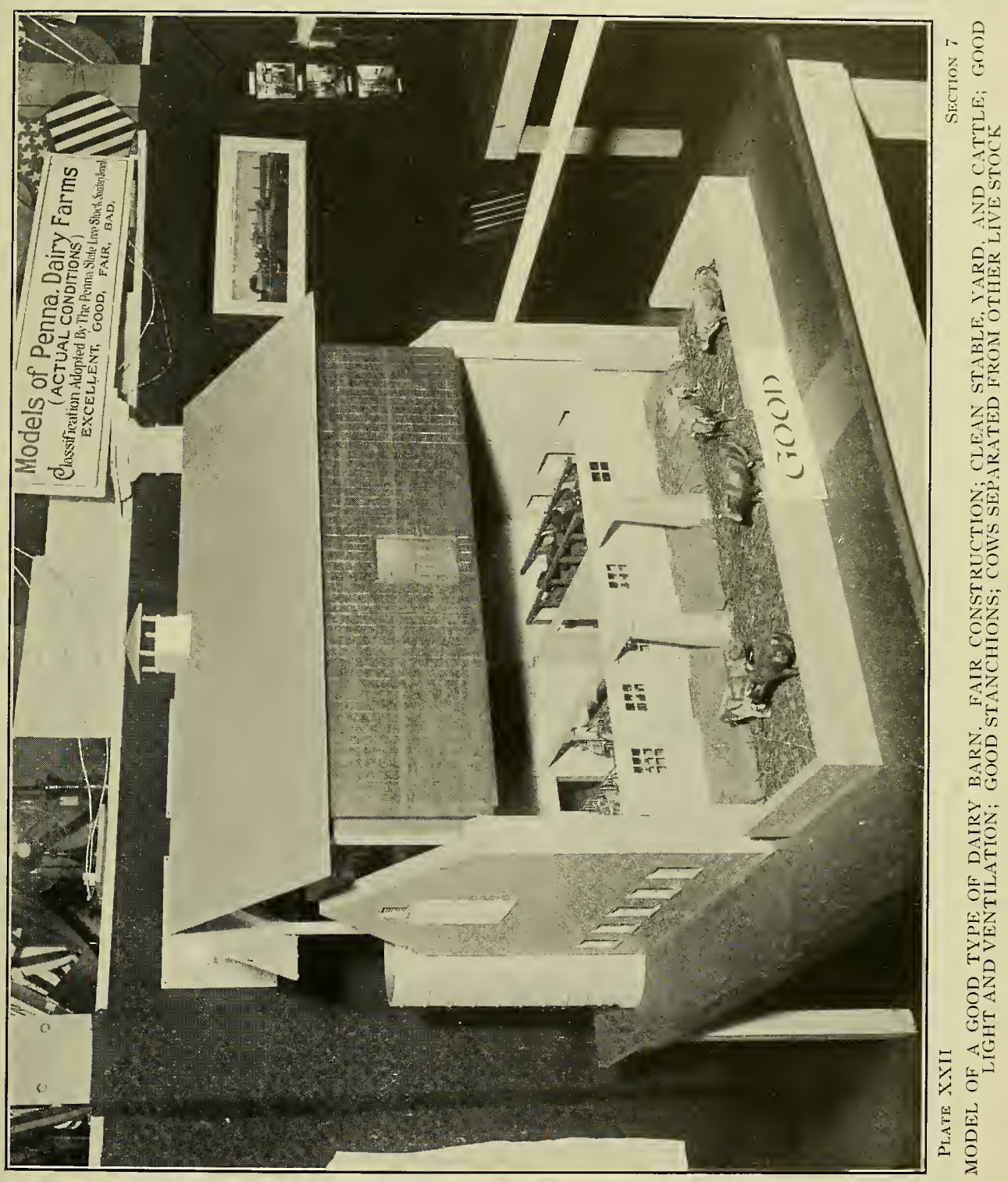





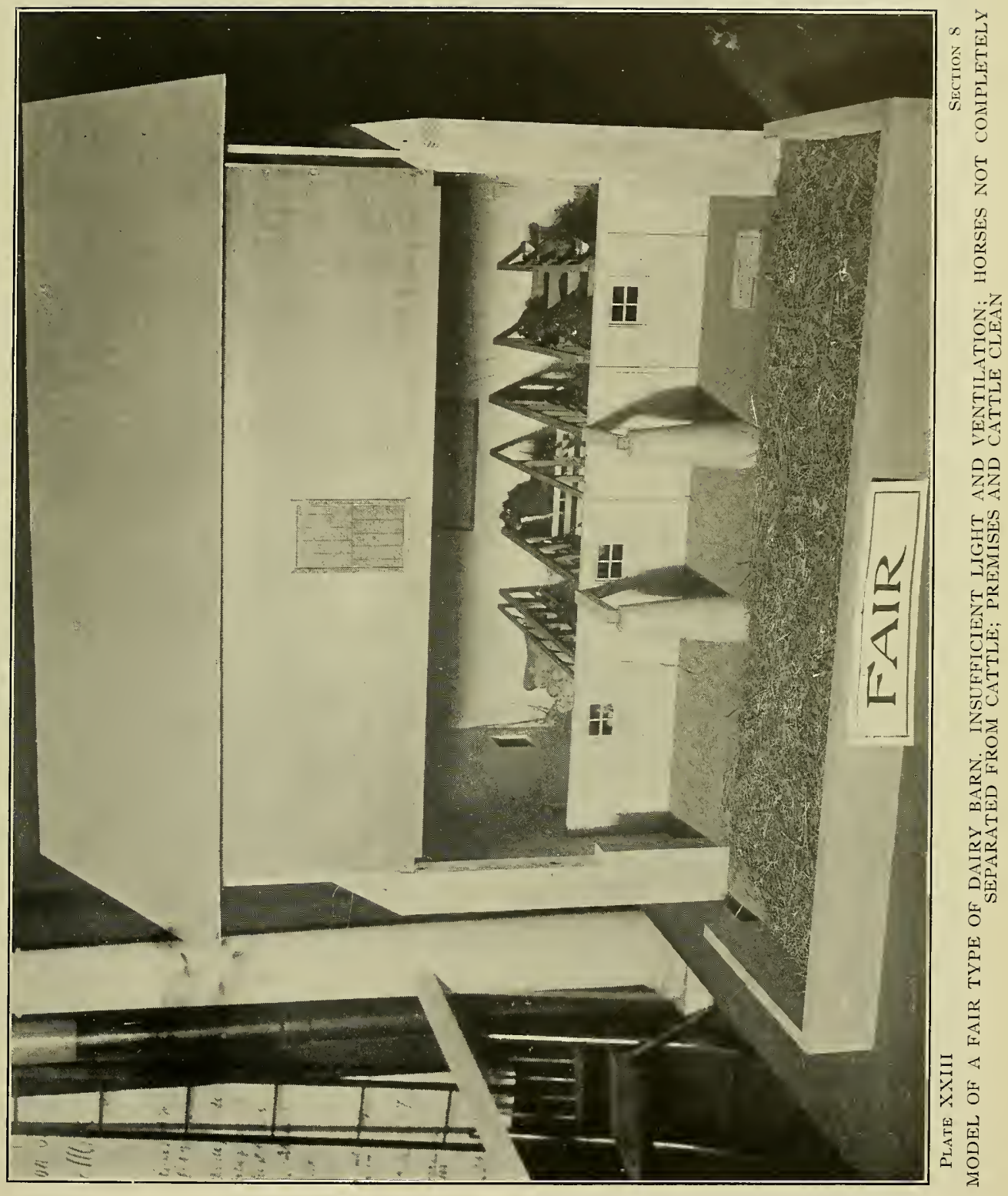





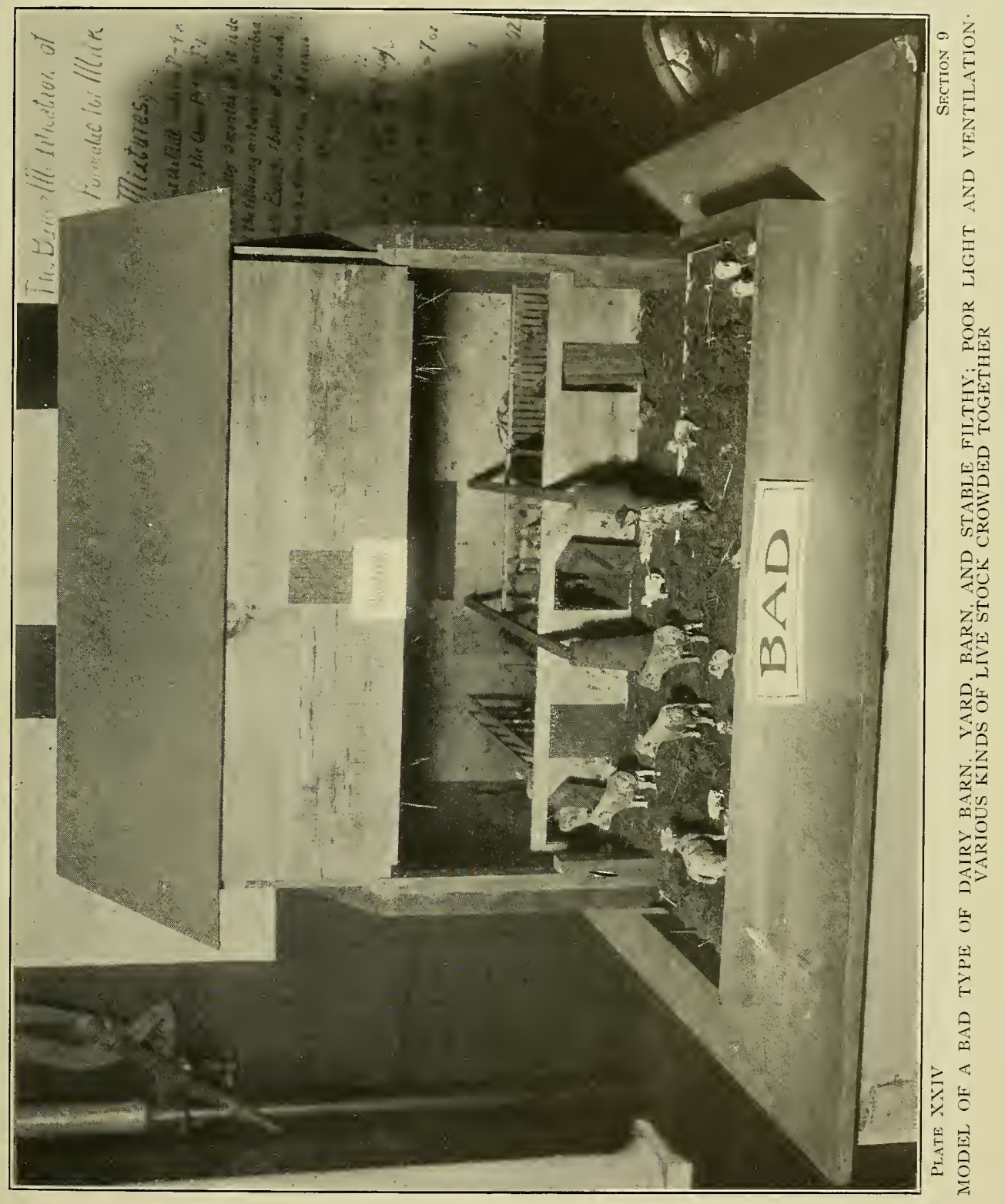






\section{Sections 6, 7, 8 and 9-Plates XXI, XXII, XXIII and XXIV Exhibit of the Pennsylvania State Live Stock Sanitary Board}

Each of these sections contained a model of various types of dairy barns, following the classification adopted by the Pennsylvania State Live Stock Sanitary Board, namely-(1) excellent, (2) good, (3) fair, and (4) bad. Mr. Charles H. Hillman of this city contributed his services in designing these models which accurately reproduced existing conditions. All the models showed the barns as in actual use with the cattle in their places, barn yards filled with straw, manure scattered about, etc., in accordance with the type represented.

1. The excellent type of barn was completely equipped with a ventilation system; clean cement floor and tight walls and ceilings; improved metal stanchions; an abundance of windows; no other live stock beside cows; individual feeding troughs and watering basins; good clean bedding; no manure piles accessible to cattle; and cows well groomed and in good condition.

2. The good stable represented an old-fashioned combination barn. Windows and ventilation were provided; floors, walls and ceiling were well constructed, clean and dust-proof; stanchions were provided; tight partitions separated cows and other live stock; cattle were groomed and bedded; and the barn yard was clean and dry.

3. The fair stable was similar to the good stable, but was provided with oldfashioned mangers instead of stanchions; no tight partitions separated cows from other live stock; floors, manure gutters and walls were of good construction, but no adequate arrangements, however, were made for light and ventilation; barn yard was clean; and cattle were in fair condition.

4. The last, or $b a d$, type of stable represented that all too common type of barn where no intelligent provisions were made for windows, floors or ventilation; cows, horses, pigs and other live stock and poultry, all occupied the same barn and yard; no attention was given to cleanliness; the barn yard was filthy; and the cows were covered with caked dirt and manure.

The lesson to be learned from these models was strikingly shown. No one could fail to see that even the bad type of stable, if slightly altered and improved, mainly through methods rather than equipment, could be classed as fair, and with the addition of better equipment and facilities would be included in the good class.

\section{SECTION 10}

\section{Exhibit of the Pennsylvania Society for the Prevention of Tuberculosis}

This section was reserved primarily for the purpose of selling the special milk number of "The Fresh Air Magazine" for May, 1911. The booth was adorned with photographs showing the need of fresh air and good milk, and an attendant was stationed here for the purpose of selling the magazine for five cents a copy.

\section{Section 11-Plate XXV \\ Exhibit of the Bureau of Municipal Research of Philadelphia}

In this exhibit were:

1. A large chart showing the various steps in the production, transportation, and sale of milk as represented by the links of a chain which was festooned in four large loops representing (1) the producer, (2) the carrier, (3) the dealer, and (4) the consumer. Each link in the chain denoted a step in the process of getting the milk 
supply, the individual links (or possible sources of contamination) being marked as follows:

1. Producer:

Cow, veterinarian, stable, yard, milker, pail, milk house, can, farm wagon, dairy inspector

2. Carrier:

Shipping platform, milk car, railroad employe, receiving platform, milk inspector

3. Dealer:

Pasteurizing plant, bottling plant, bottle, delivery wagon, driver

4. Consumer:

Kitchen, kitchen utensils, refrigerator, nursery, nursing bottle.

How Strong Is This Chain? Where Are The Weakest Links?

2. Chart reading:

YES, QUALITY IS IMPORTANT, BUT DO YOU GET FULL MEASURE?

Picture
of a full
measure
milk bottle

Picture of a short

measure

milk bottle

\section{THE MILK IN THE BOTTLE SHOULD REACH TO THE CAP RING OR STOPPLE}

3. Chart summarizing present city milk inspection service:

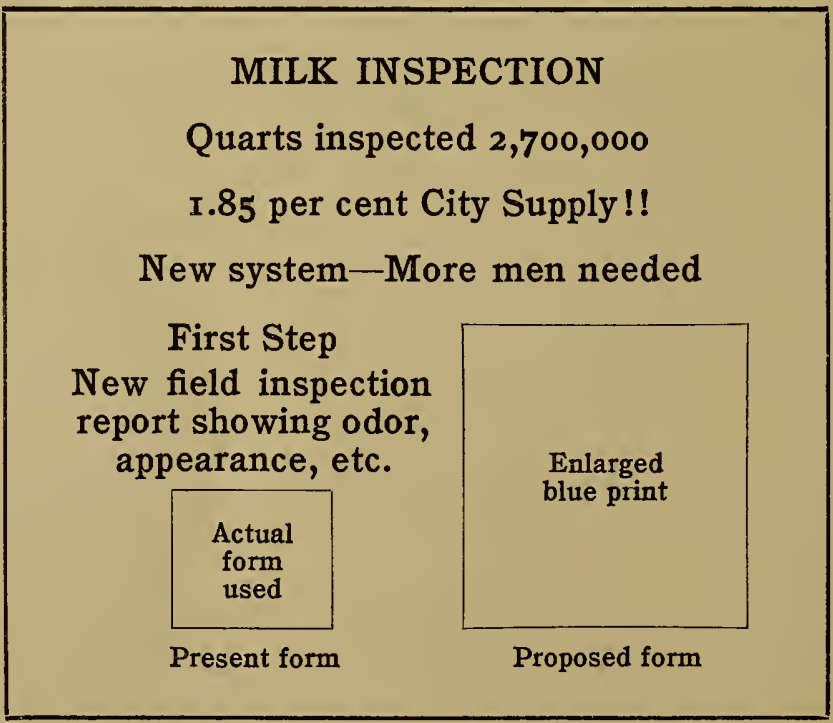




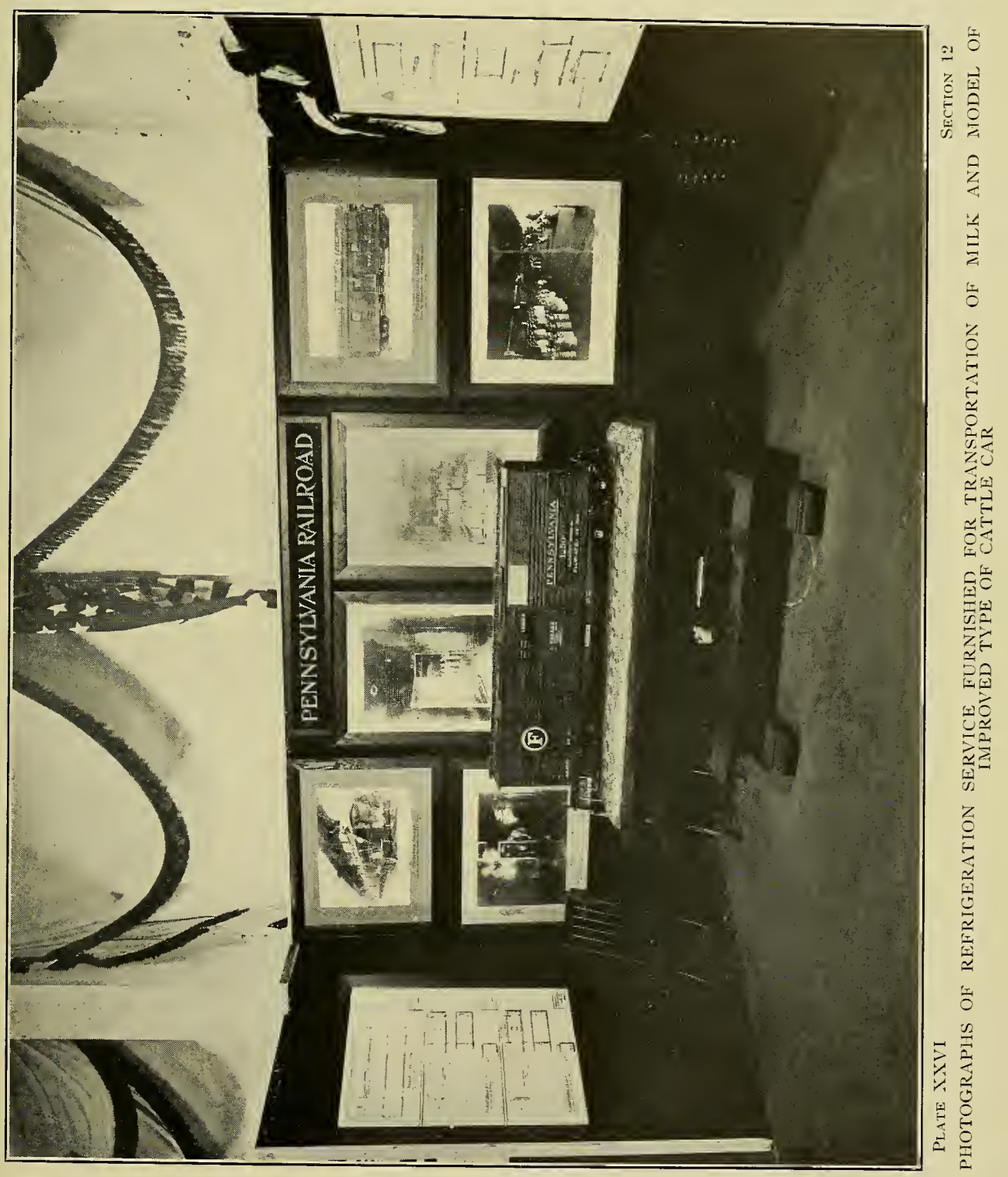





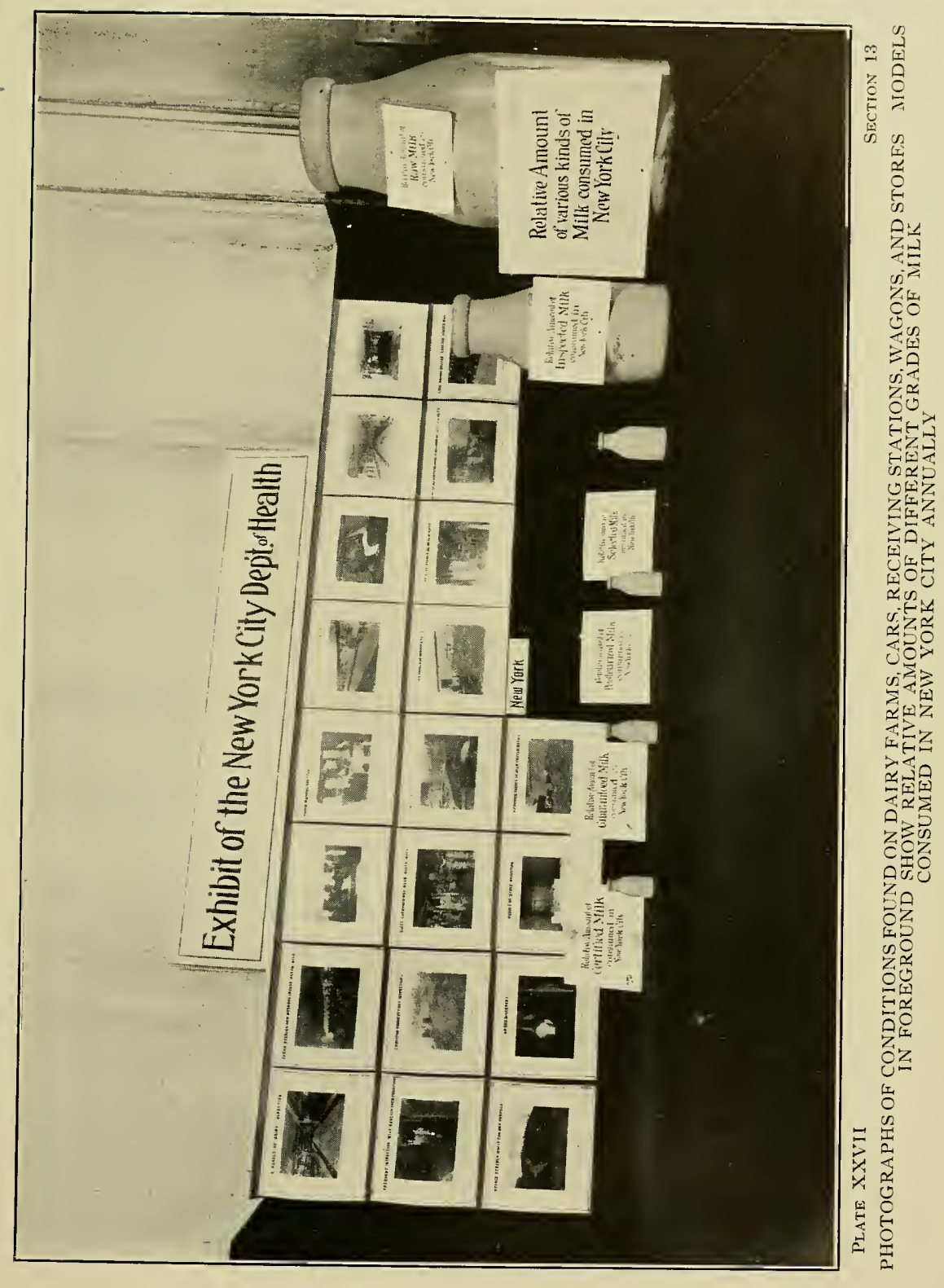



4. Chart showing infant mortality:

(Diagram here)

THE SUMMER WAVE OF BABIES' DEATHS IS PREVENTABLE DOTTED LINE . . . . DE DEATS FROM DIARRHEA

CHIEF CAUSE-DIRTY MILK

KEEP MILK $\begin{array}{ll}\text { CLEAN } \\ \text { COLD }\end{array}$

5. Map showing sources of Philadelphia milk supply giving car load shipments on all railroads.

\section{Section 12-Plate XXVI \\ Exhibit of the Pennsylvania Railroad Company}

This attractive exhibit, which was in charge of an attendant who explained points and answered questions, consisted of:

1. Wooden model of a cattle car

2. Photographs showing:

a. Icing of express cars used in the milk service

b. Scrubbing cars after unloading at milk receiving stations previous to reloading with empty cans for return trip

c. Interior of refrigerator car showing ice boxes, insulated bulkheads, and doors

d. Refrigerator car modified for solid car load milk shipments

e. Milk receiving platform - arrival and unloading of solid milk train

3. Sectional drawings showing the construction of refrigerator cars

4. During two days of the Show, several types of cars used in the transportation of milk were open for inspection on a siding in one of the freight yards in West Philadelphia.

\section{Section 13-Plate XXVII}

Exhibit of the New York City Department of Health; the New York Milk Committee; and the Massachusetts Mill Consumers' Association

1. The exhibit of the New York City health department consisted of large framed photographs illustrating the different aspects of the milk supply of New York City. These photographs were very good, the subject matter having been carefully chosen and the workmanship excellent. Among the captions under the various views were the following:

1. Type of stable being eliminated

2. Bacterial content being reduced. (A picture of a good stable)

3. One step toward clean milk. (A view in a sanitary bottling plant) 
4. Cows should be kept in spacious, clean and light stables

5 and 6. Condition found at first inspection, and, on the same line, another photograph showing the condition found at re-inspection

7. Frequent inspection will abolish such conditions. (View showing the interior of a milk store where the sales room had direct connection with a bed room)

8. One effort to improve care of milk in stores. (A picture of the milk booth which is installed in many New York stores)

9. Result of store inspection. (This view shows the interior of a small store selling milk and eggs. A clean counter is visible in the foreground and a good ice box is also shown)

10. Frequent white-washing recommended by this department. (This picture shows a sprayer on wheels, drawn by one horse, which is used for white-washing cow stables)

11. Built according to rules of department of health. (Interior of a sanitary cow stable)

12. Clean stables and methods insure clean milk. (Interior view showing a stable with a row of cows and milkers at milking time with a printed caption beneath, "Producing milk of the highest grade")

13. Only healthy cows can produce wholesome milk. (This photograph shows a row of cows in a stable and a veterinarian at work examining the herd)

14. Manure which could be utilized to advantage. (This view shows a large pile of valuable manure which is close to the side of the stable)

15. Common source of milk contamination. (This view shows a cow yard with a stable in the background and piles of manure near the stable, in which cows are walking)

16. Type of stable being eliminated. (A bad interior)

17. Inspections of this kind are made every night. (This view, taken by flash light, shows the milk inspectors at work inspecting milk at one of the railroad stations at midnight)

18. 5,500 wagons deliver two million quarts daily. (This view shows the inspectors inspecting milk on the wagons in the early morning)

19. Frequent inspection would correct this. (An interior view of an unsanitary creamery)

20. All milk entering New York should be inspected. (A view showing a railroad receiving platform with its long lines of milk cans)

21. Millions of bacteria in such milk. (An interior view in a milk store with insanitary surroundings)

22. Impossible to safeguard milk under such conditions. (Interior of a milk store showing milk can at open doorway of a basement grocery. A caption reads, "No ice used")

\section{The New York Milk Committee exhibited:}

1. Set of twelve large framed photographs representing the work of infants' milk stations

2. Set of twelve large framed photographs representing various conditions of sanitary and insanitary milk production in New York City

3. Wooden models of filled milk bottles, graded in size, to show the relative amounts of the various kinds of milk consumed in New York City annually. The models ranged in size from the large bottle at the head of the line, standing about five feet high, and representing the relative amount of raw milk consumed; to a small model at the foot of the line, measuring about eight inches in height, and representing the relative amount of certified milk consumed. The kinds of milk represented by models were:
1. Certified milk
2. Guaranteed milk
3. Selected milk
4. Pasteurized milk
5. Inspected milk
6. Raw milk

3. Occupying a small corner of this booth was a chart containing copies of leaflets issued by the Massachusetts Milk Consumers' Association of Boston-an association formed to unite consumers in obtaining efficient inspection and a pure milk supply. 


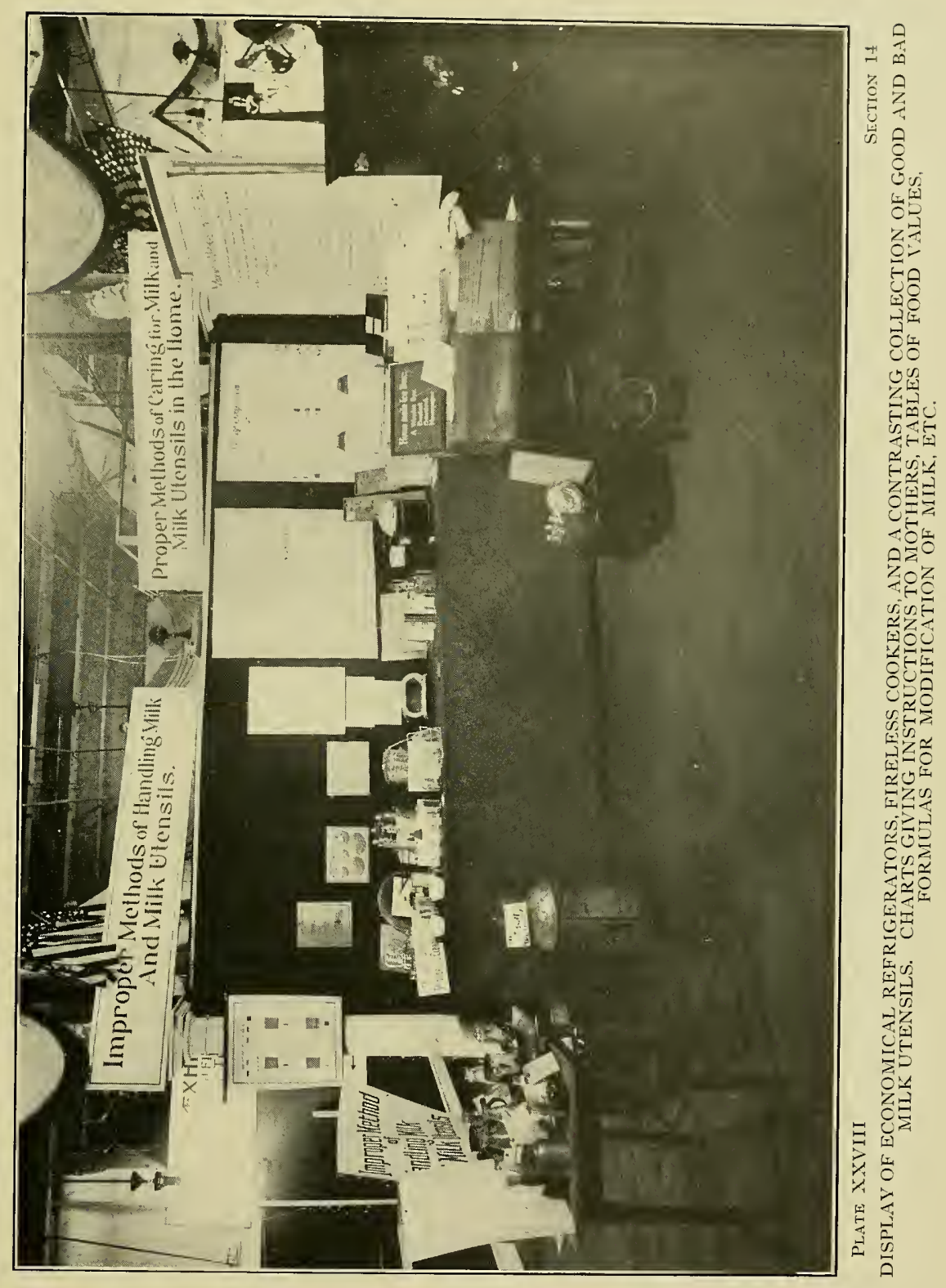





\section{Section 14-Plate XXVIII}

\section{Exhibit of Proper and Improper Methods of Caring for Milk in the Home}

This exhibit was of great practical value because the ease with which milk might become contaminated and the consequent dangers were strikingly shown by having on display a collection of insanitary utensils actually found in use in dirty homes and milk shops. In contrast with these unsafe utensils, others were displayed to teach the proper way of caring for milk,-refrigerators, sterilizers, cleansers, door-step bottle holders, etc. Trained nurses gave valuable service as attendants in this section, explaining the principles and construction of the utensils shown and also pointing out the unseen dangers. Among the articles shown were various makes and sizes of glass nursing bottles which were to be avoided as being unsafe, while types to be recommended were shown alongside. Nipples not easily cleaned, and therefore to be avoided, were shown with others that were to be recommended because they could be easily and thoroughly cleaned.

Many kinds of refrigerators were shown, for example:

A home-made ice box, devised by the Phipps Institute, costing about ten cents, requiring two cents' worth of ice daily

Another home-made ice box, costing about forty-five cents, constructed from a wooden box, sawdust, a tin pail, and newspapers. In this box two cents' worth of ice will last twenty-four hours

A Hess refrigerator devised by Doctor Hess of New York, loaned by him

Portable hygienic refrigerators, different sizes, requiring two cents' worth of ice, price according to size

McCray refrigerator, loaned by the company

Star refrigerator, loaned by the company

Other utensils displayed included:

A home-made fireless cooker, devised by the Phipps Institute, costing about ten cents Electric fireless cooker

Cereal fireless cooker

Freman pasteurizer

Arnold steam sterilizer and pasteurizer

Bottle cleaners

Receptacle for milk bottles, loaned by the Government

On the walls of this section were several instructive charts:

1. Chart showing the stomach at different periods of infancy-life size-to illustrate the reason for variation in the amount of feeding at different ages:

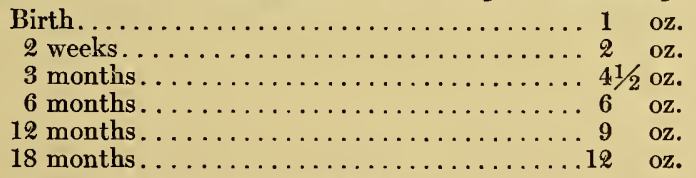

2. Maxims for mothers of bottle-fed babies:

(Holt)

1. Sterilize bottles and nipples by boiling every day. Have all utensils clean.

2. Have a bottle for every feeding. Avoid all unnecessary handling of the milk.

3. Bottles and nipples should be of the most simple design to be easily cleaned.

4. Never vary an iota from directions in the preparation of food. Much harm may be done from ignorant deviation.

5. Do not use the bottle as a standard in measuring ounces. Bottles vary in size.

6. When the bottles for the day are filled, stopper them with sterile non-absorbent cotton or with rubber corks which may be readily boiled.

7. Keep the bottles on ice until they are ready for use.

8. Heat the bottle to blood heat or slightly above just before feeding. 
9. Do not taste the milk in the bottle before giving it to the baby.

10. If the nipple falls on the floor or comes in contact with soiled objects, do not use it.

11. In travelling do not heat the bottle before starting. Carry it cold.

12. Do not trust the baby to feed himself. Feed him or watch him while he feeds.

13. Cleanse the bottle and nipple immediately after feeding. Never leave a partially emptied bottle in the crib or on the window sill.

14. Never use any food that the baby has discarded.

15. Do not ask your milkman to leave milk early in the morning. Rather encourage him to make a later delivery.

16. View any milk mixture as a splendid feeding ground for germ life. Let your whole system of feeding be directed toward the avoidance of infection.

3. Average composition:

Human Milk (Richmond)
Water................ 88.2

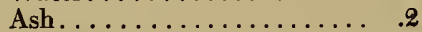
Proteids.............. 1.5
Fat. . . . . . . . . . 3.3
Sugar. ............... 6.8

Cow's Milk (Richmond)
87.1
.75
3.4
3.9
4.75

Fat should not be confounded with cream, as it represents but one of its constituents.

4. The calorimetric method of infant feeding:

This method strives to adjust the infant's diet so that he may receive from it the proper amount of energy

A calorie of energy unit is the amount of heat required to raise 1 kilogram of water $.1^{\circ} \mathrm{C}$. in temperature

A young baby requires 100 calories for every kilogram ( $2 \frac{1}{5} \mathrm{lbs}$.) of its weight

1 gram of fat yields............. 9.3 calories

1 gram of sugar yields............. 4.1

1 gram of proteid yields........... 4.1 "6

1 ounce of milk yields......... "

1 ounce of cream yields............. 54

This method furnishes a good check on other methods.

5. Tables of food values, prepared by the Department of Agriculture

6. Chart of the growth of bacteria, in properly and improperly cooled milk. Chapin

7. Cartoon of a cat stealing milk from bottle on door step with explanation of the dangers

from such careless handling of milk bottles upon delivery.

\section{Section 15-Plate XXIX \\ Exhibit of Demonstration of the Uses of Milk as a Food}

This section was also one of great practical value to the majority of visitors, since there were held frequent demonstrations of the modification of milk for infant feeding and demonstrations of the uses of milk in cooking.

A skilled demonstrator in cooking, with the necessary helpers, interested the crowds in the ways of preparing appetizing and nutritious dishes from milk.

An article in the North American is thoroughly descriptive of the other phases of this exhibit:

\section{TELLS OF BABY FOODS FOR THE HOT WEATHER Trained Nurse Gives Demonstration and Formulas at Milk Show MEN MUCH INTERESTED}

The vital question, "What shall I feed the baby in the hot weather?" is being answered daily at the Philadelphia Milk Show by a woman who has had experience in feeding hundreds of babies and who stands ready at all times to give uncertain mothers the benefit of this experience.

Miss L. Cates, a trained nurse in charge of the children's department of the Woman's Hospital, presides over the model kitchen at the Show, which has been fitted up by a committee of women physicians of the city, and here, among a collection of snow-white 


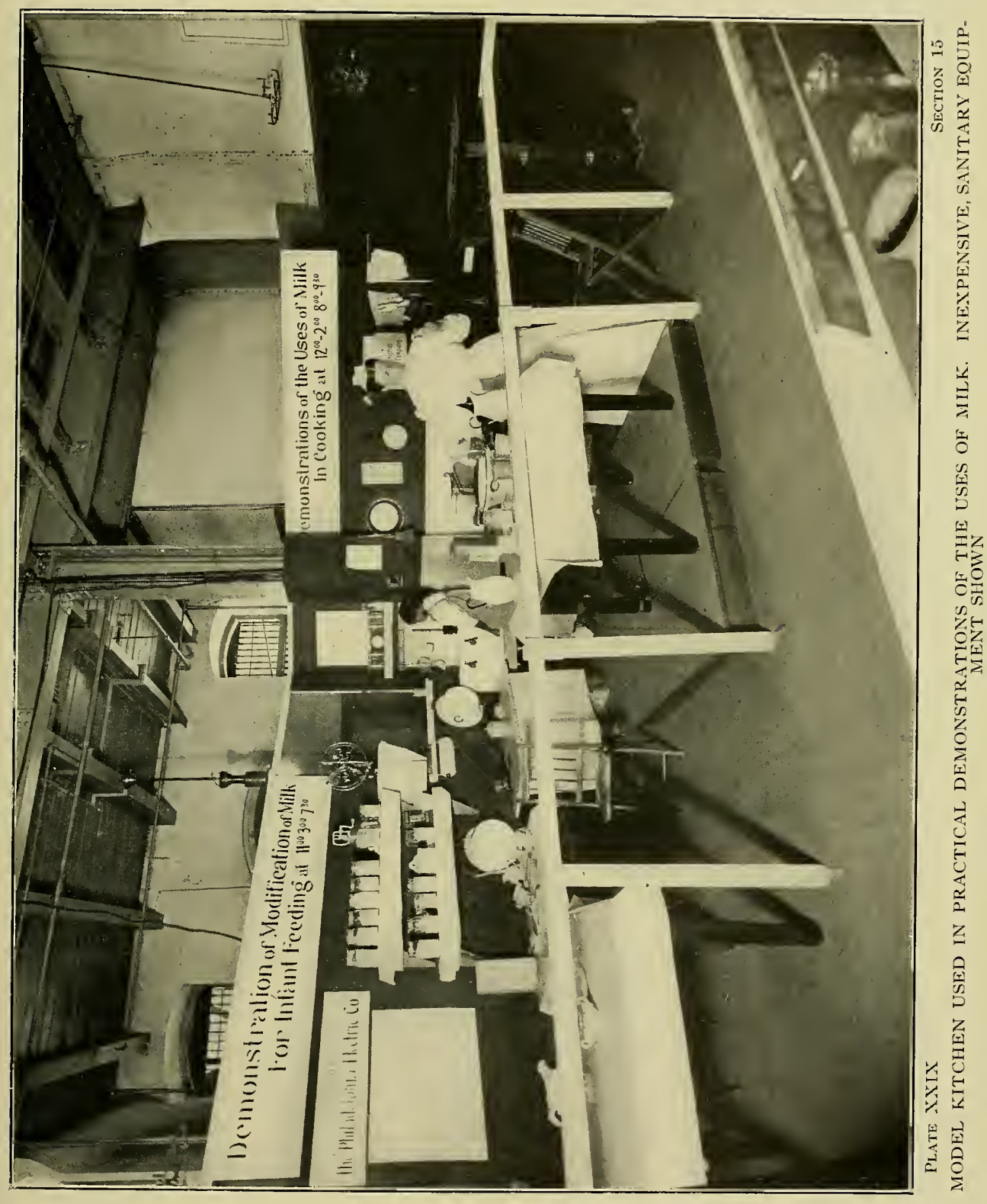



cooking utensils, dressed in her snow-white uniform, she not only gives information as to the most scientific infant feeding, but she deftly prepares the food she recommends and gives the formulas to those who request them.

Strange to say, she is besieged by men who take surprising interest in the preparation of bottles for babies, and who ply her with questions relative to the value of rice water and whey, and who want to know if buttermilk is good in intestinal trouble of infants.

\section{Foods for the Little Ones}

To all inquiries Miss Cates makes the same reply-the one that every trained nurse makes - that the doctor must be consulted and his word on the baby's diet taken as final. Then she shows how to prepare the food-in case be recommends it-in the manner in which she has prepared it for the hundreds of little ones who have thrived under her care at the hospital.

Yesterday she demonstrated half a dozen food preparations designed to relieve the little ones suffering from digestive troubles, for whom undiluted cow's milk is too heavy in hot weather. Buttermilk, peptonizer milk, rice water, barley water and whey were among the foods that were prepared at the morning and afternoon demonstrations.

"Rice water and buttermilk," Miss Cates said, "are frequently recommended for babies suffering with intestinal troubles, and the two are used in connection with each other as hot-weather food. There are several kinds of buttermilk, but the easiest to obtain in the city is that made from sweet milk by the addition of buttermilk tablets. To a quart of fresh milk, which is placed in a clean pitcher, jar or bottle, after boiling, add one-third to one-half a quart of hot water, according to the richness of the milk, a pinch of salt and one pulverized tablet. Let this stand at a temperature of 70 degrees for twentyfour hours before using.

\section{Process used in Hospitals}

In making barley-and-rice water, Miss Cates recommended the use of the cereal grains, which are cheaper than the flour. For rice water she soaked $21 / 2$ teaspoonfuls of rice three hours in a quart of water, then boiled it slowly for an hour, adding a tablespoon of sugar to a quart of the fluid and a pinch of salt. For whey she heated a pint of milk to a degree known as lukewarm, and after placing a junket tablet in cold water, added it to the milk, allowing it to stand until firm. She then beat the mixture with a fork, strained it through a piece of cheesecloth and threw away the curds.

"Peptonized milk," she said, "is invaluable for children who are not able to digest plain cow's milk, and the best way to make it according to the warm process used in hospitals, is to add one tube of peptonizing powder, dissolved in warm water, to a pint of milk, letting the mixture stand in warm water at a temperature of 110 degrees for ten, fifteen or twenty minutes, as ordered.

\section{Among the articles and materials used in this exhibit were:}

Agate and white enamel double boilers

Agate and white enamel spoons, different sizes

Agate and white enamel bowls

Agate and white enamel pitchers

Agate and white enamel dish pans

Agate and white enamel tea kettles

Glass jars, different sizes

Wire strainers, different sizes

Glass churns, different sizes

Agate and white enamel quart measure

Agate and white enamel funnels

Glass measuring cup

Sanitary paper towels

16 ounce glass graduates

"Materna" glass graduate

Chapin dippers

Glass funnels

Absorbent and non-absorbent cotton

Borax

Boric acid

Lactone tablets

Kefilac tablets

Junket tablets

"Bulgarian" tablets

Essence of pepsin

Liquid rennet 
Many electric cooking utensils were loaned for display by the Philadelphia Electric Company.

Gimbel Brothers, Dennison Manufacturing Company, George B. Evans, Charles Lentz, and Llewellyn's Drug Company kindly allowed certain articles, which had been purchased, to be returned to them after the Show (if in good condition) and credit given accordingly.

\section{Section 16-Plate XXX}

Exhibit Showing the Modern Method of Maling Ice Cream; and the Results of Bacteriological Examination of Ice Cream by the Pennsylvania State

Live Stock Sanitary Board

Many photographs in this section portrayed dirty methods, undesirable stores, itinerant venders, etc. Plate cultures were shown of bacteria found in poor ice cream and the results of chemical analyses of the same. Finally, a modern rotary freezer with a capacity of one hundred and eighty quarts per hour was exhibited, capable of being thoroughly cleaned and sterilized. This machine was shown in operation.

Among the charts shown in this section were:

\section{WHAT DO YOU KNOW ABOUT THE ICE CREAM SOLD BY STREET VENDERS?}

THIS IS WHAT WE CAN TELL YOU

ICE CREAM SHOULD LEGALLY CONTAIN

$6 \%$ butter fat when flavored with fruits

$8 \%$ butter fat when other flavors are used

CHEMICAL EXAMINATION OF I25 SAMPLES OF ICE CREAM SOLD BY STREET VENDERS GAVE THE FOLLOWING RESULTS:

80 samples contained less than $\mathrm{I} \%$ butter fat 30 samples contained between $1 \%$ and $2 \%$ butter fat

only 5 samples of the total number contained the legal amount of fat

SOME FACTS REGARDING FLAVORS

IO SAMPLES OF THE SO-CALLED FRUIT FLAVORS CONTAINED SUBSTANCES CALLED "COMPOUND ETHERS" AS SUBSTITUTES FOR FRUIT FLAVORS 


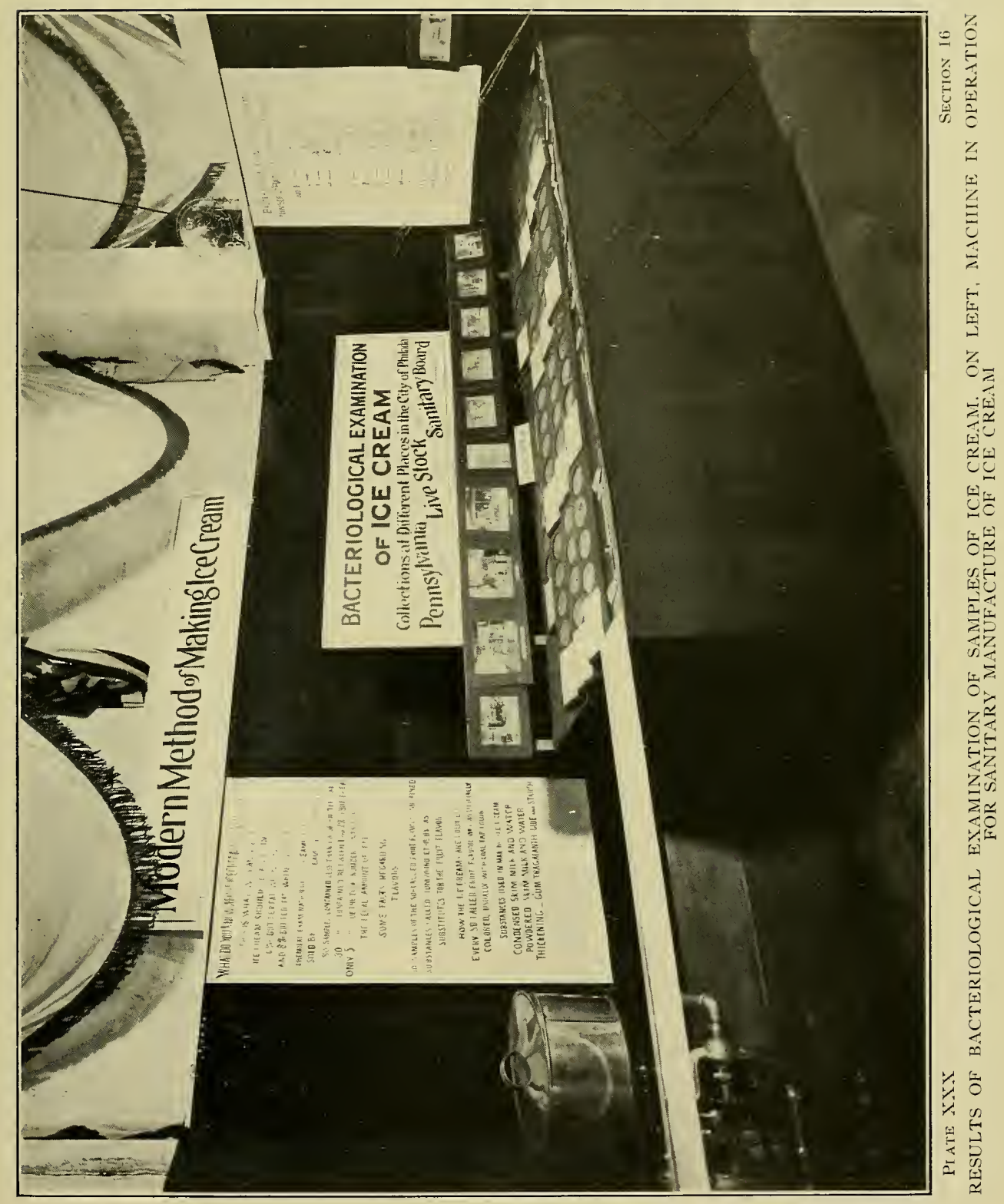





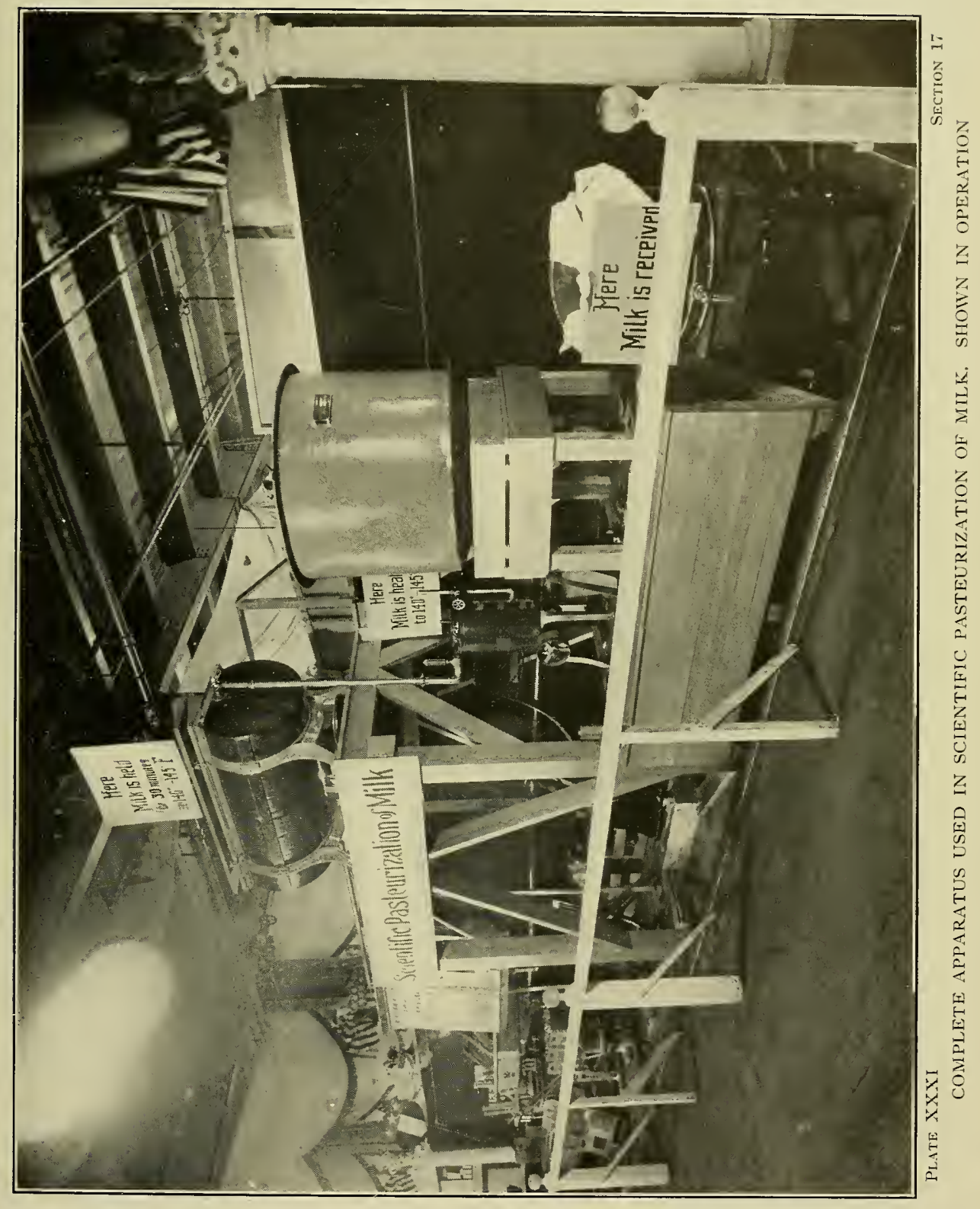





\section{HOW THE ICE CREAMS ARE COLORED}

Every so-called fruit flavor was artificially colored, usually with coal tar color

\section{SUBSTANCES USED IN MAKING ICE CREAM}

Condensed skim milk and water

Powdered skim milk and water

Thickening gum tragacanth, glue and starch

\section{BACTERIOLOGICAL COUNTS OF ICE CREAM SAMPLES}

\begin{tabular}{rr} 
Number of bacteria per \\
\multicolumn{2}{c}{ cubic centimeter } \\
I & \multicolumn{1}{c}{ I7,600,000 } \\
2 & I, 030,000 \\
3 & $38,600,000$ \\
4 & $8,160,000$ \\
5 & $40,300,000$ \\
6 & $14,400,000$ \\
7 & $8,200,000$ \\
8 & $5,000,000$ \\
9 & $7,650,000$ \\
I0 & $I, 820,000$ \\
II & $22,200,000$ \\
I2 & $9,740,000$ \\
I3 & I0,200,000 \\
I4 & I6,2I 2,000
\end{tabular}

\section{Section 17-Plate XXXI}

Exhibit Showing the Scientific Pasteurization of Mill

Here visitors could see a complete system of pasteurization in operation as followed in one of the most up-to-date and scientific pasteurizing plants. For this purpose there was installed in this section at considerable expense a complete plant consisting of the most modern and sanitary pasteurizing apparatus, a mechanical bottle filler, a capping machine, a bottle washer, and a centrifugal cream separator. Attendants were on duty to explain the processes and apparatus.

In demonstrating the operation of pasteurization, water was used in place of milk. It was first passed through filter cloth into the receiving vat, thence it passed by gravity to the pasteurizer, which heated it to $140^{\circ}-145^{\circ} \mathrm{F}$., and at the same time threw it by centrifugal force up to the "holder" on an elevated platform where the 
heated water was held for thirty minutes. It then dropped by gravity to the cooler, where the temperature was reduced to $40^{\circ} \mathrm{F}$. From the cooler it dropped by gravity to the bottle-filler, a mechanical device worked by a hand lever. The box of filled bottles was then pushed along a platform to the capping machine, a distance of two feet, where they were finally capped. For the purpose of demonstration, the cover of the cooler was made with a glass window to permit the spectators to see the fluid in its passage over the cooling $\mathrm{pi}_{\mathrm{i}}$ :s.

The special points about the srocess were:

1. The absence of a pump, the fluid running by gravity after leaving the holder

2. The short length of piping

3. The fact that the cooler was covered, preventing air contamination

4. The fact that there was exposure to the air only for the few seconds consumed in passing the bottles from the filler to the capper.

The bottle washer exhibited, consisted of a soaking tank, a revolving brush for badly caked bottles, and a device for throwing a jet of hot water and another for steam or boiling water.

The cream separator was of the type giving eight thousand revolutions per minute.

Sections 18, 19, and 20-Plates XXXII, XXXIII, and XXXIV

Exhibit on Child Hygiene by the Philadelphia Department of Public Health and Charities

These three sections contained the main features of the various exhibits which have been held with such beneficial results at different times by the Bureau of Health in the congested districts of this city.

Photographs were shown illustrating:

1. Visiting nurses' work and general housing conditions

2. Exterior of exhibits held in slums

3. Open air hospitals, educational centers, play apparatus, playgrounds, and a practical demonstration of care of babies and children on two large recreation piers

4. Philadelphia parks

5. Wards, Philadelphia General Hospital

6. Redbank Sanitarium

7. Medical clinics and milk stations

8. Modified milk stations

9. Care of baby

10. Dirty milk and dirty milk bottles

11. Preparation of baby's food

12. Necessity of vaccination

13. Instructions to school children

14. Cheap home-made ice box

Illustrated wall placards, paintings and models explaining certain truths to mothers, such as:

1. Placard giving instructions for mothers

2. Placards giving instructions on care of the baby

3. Display circular-Care of the Baby

4. Display of proper and improper nipples

5. Painting-Keep Baby's Mouth Clean

6. Painting showing foods that are dangerous

7. Card of "Don'ts" for baby feeding

8. Colored picture - showing danger of baby on unclean floor

9. Colored illustration-Bathe the Baby

10. Dressed dolls, showing proper and improper method of dressing baby 


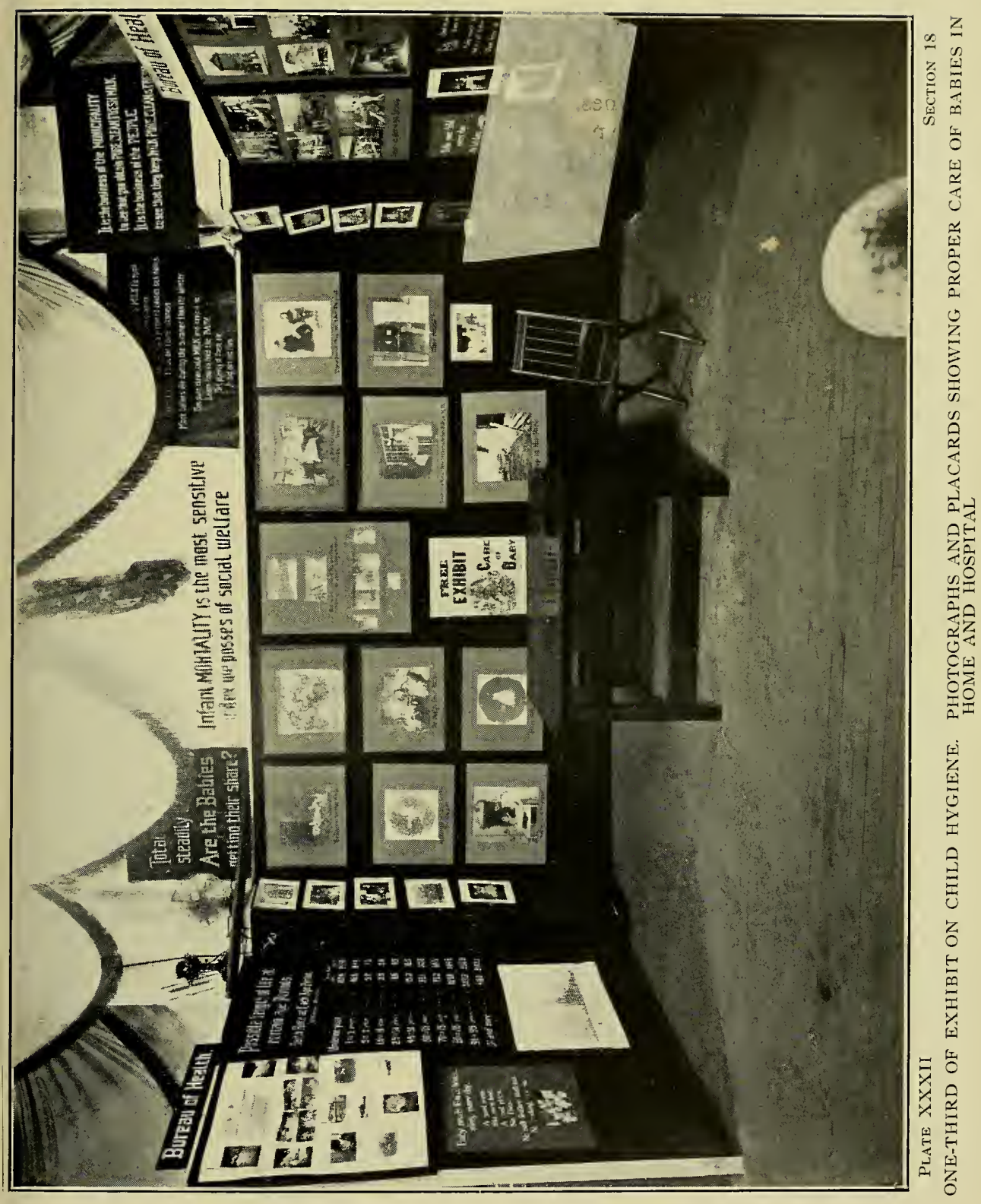





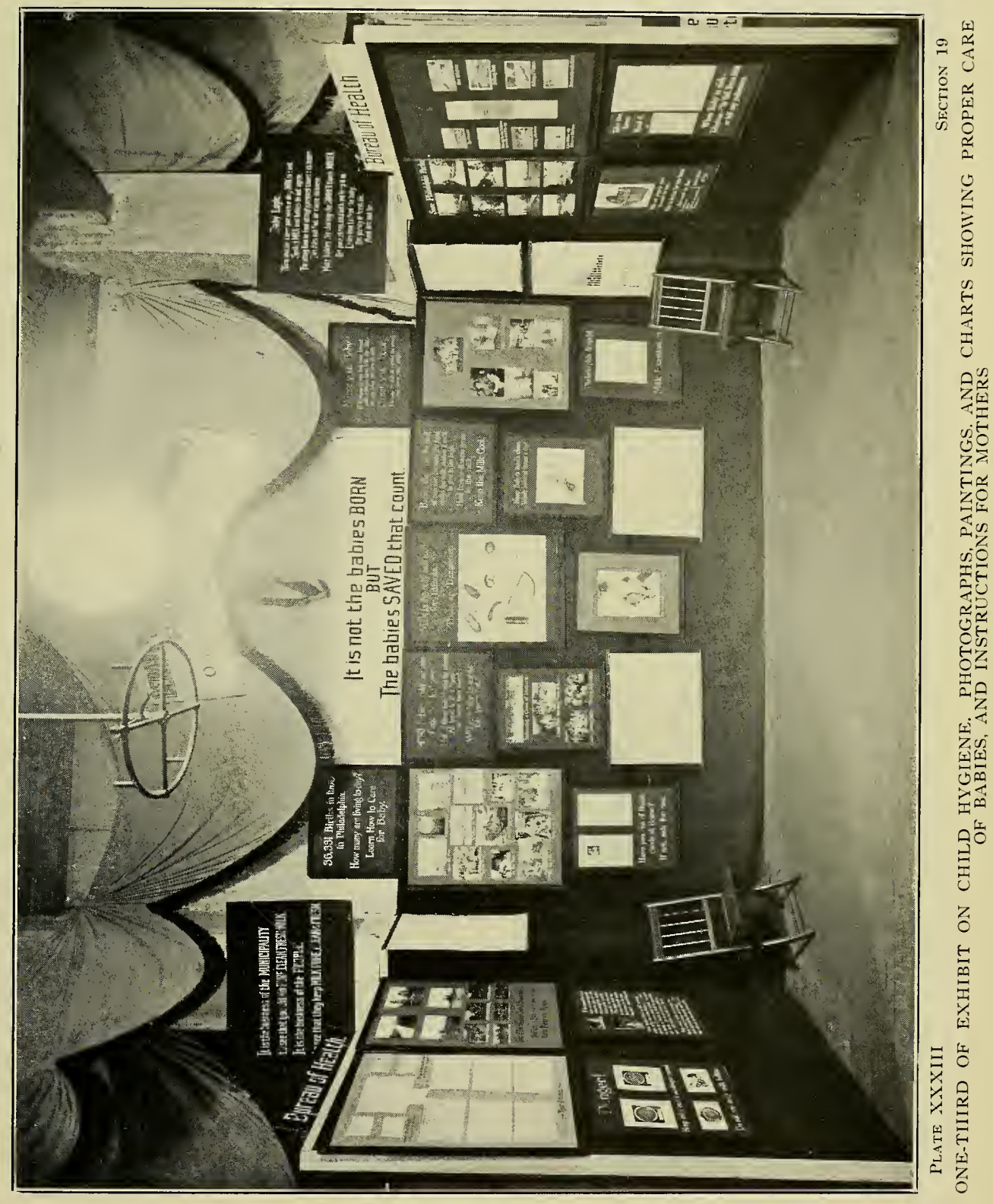





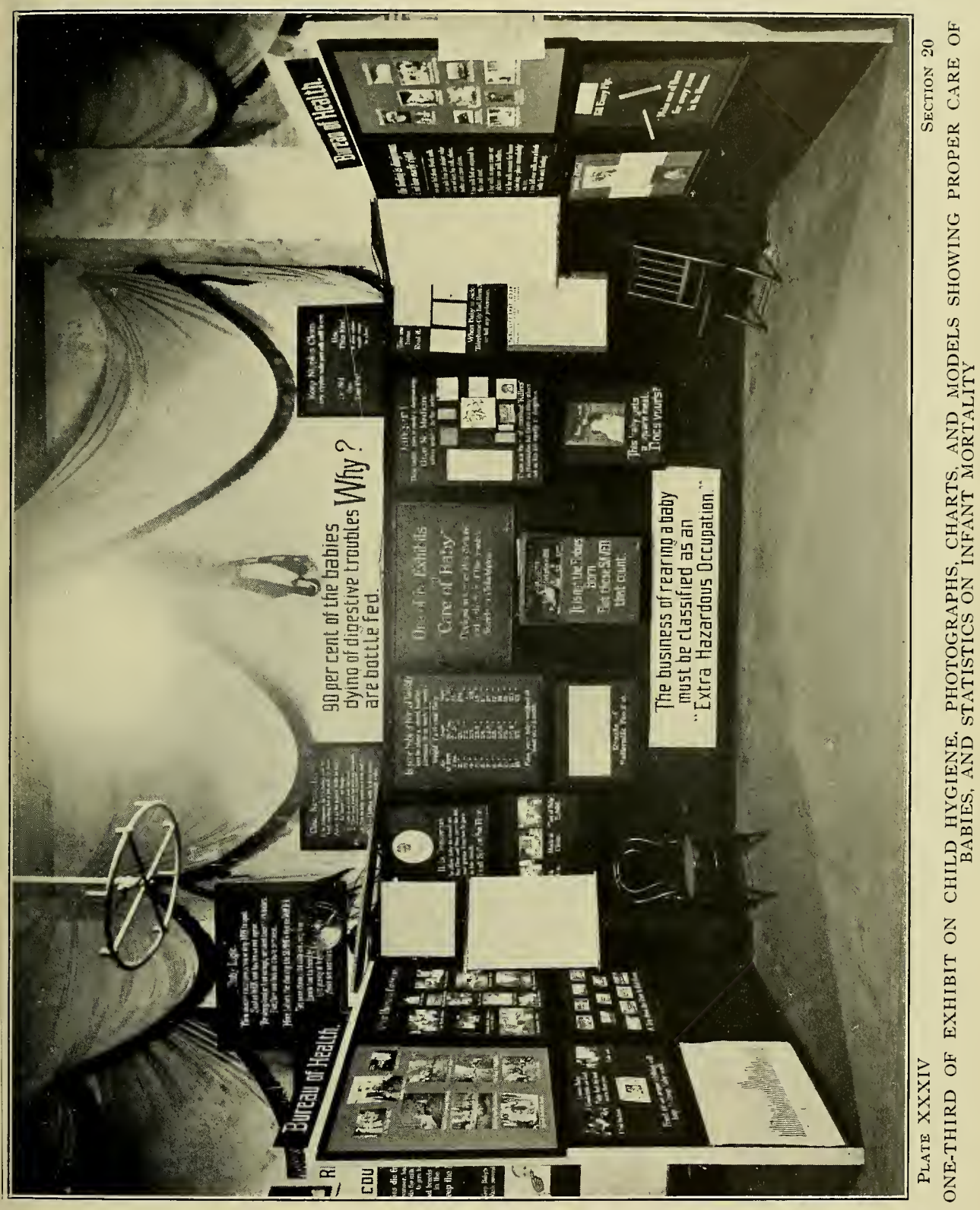



11. Model bed on chart with instructions concerning the same

12. Display circular dealing with the dangers of the house fly

13. Sample of home-made fly killer on frame

14. Report blank used by nurses

15. Details of work, Redbank Sanitarium Association 16. Models in glass case showing births and deaths among infants under one year of age
in Philadelphia

\section{Maps and charts:}

1. Deaths of children under one year, from one to two years, and from two to five years, and percentage of deaths under five years to total mortality for thirty years 2. Births and deaths from diarrhea and enteritis under two years of age in relation to
density of population, 1909 3. Births and deaths from diarrhea and enteritis under two years of age in relation to the
density of population, 1908

4. Total deaths under five years of age in relation to maximum, minimum, and mean temperature, and humidity for the year 1909

5. Total deaths under one year in relation to maximum, minimum, and mean temperature, and humidity by weeks for the year 1909

6. Total deaths under two years in relation to maximum and mean temperature, and humidity by weeks for the year 1909

7. Deaths under one year from all causes in relation to feeding; maximum, minimum, and mean temperature; and humidity during the summer 1910

8. Deaths under one year and between one and two years in relation to feeding; maximum, minimum, and mean temperature; and humidity by weeks during the
summer of 1910

9. Total deaths per 1000 of population compared with deaths under one year, deaths under two years, and deaths under five years, by years since 1880

10. Total deaths per 1000 of population compared with deaths under one year, deaths under two years, and deaths under five years, by months during the year 1909

11. Births and deaths per 1000 population for thirty years

12. Weights with different kinds of feeding, Philadelphia General Hospital

13. Bacteriological examinations of milk

14. Publicity that counts, giving head lines of newspaper articles

15. Number of births during the year and number of those living at the end of the year
16. Instructions in nursing

17. Instructions in nursing

18. Elucidating deaths of 1909

19. Bottles with labels of the more common soothing syrups, cartoons, etc., and printed matter; entitled, "Dangerous Drugs"

20. Weight of baby

21. Number of babies who died during the year

22. Death rate at each age period

23. Showing location of playgrounds and milk stations in Philadelphia

24. Showing ward lines in relation thereto

25. Showing deaths by wards from diarrhea and enteritis in children under two years of age and all deaths from all causes in children under fve years of age per 1000 population

Some of the illustrated charts on the care of babies were worded as follows:

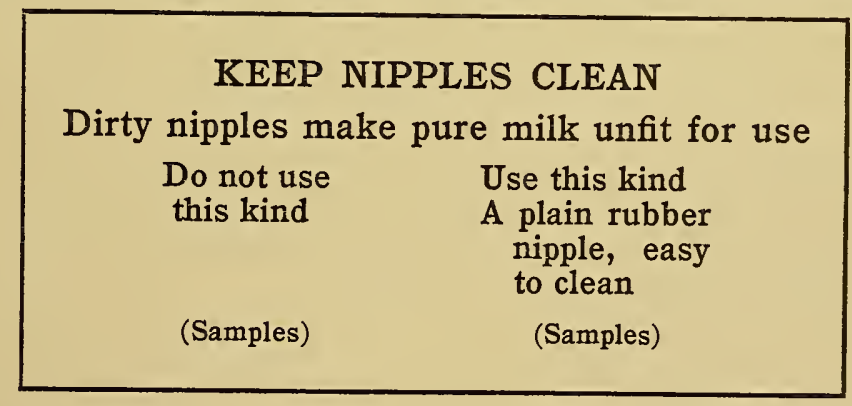




\section{(Colored picture of} baby on floor)

IT IS DANGEROUS

TO ALLOW BABY TO CRAWL ON THE FLOOR AND THEN CARRY

THE DIRT AND GERMS FROM HIS FINGERS TO HIS MOUTH

DON'T SPIT ON THE FLOOR

(Photograph of mother nursing baby)

THIS BABY GETS A SQUARE MEAL DOES YOURS?

SPEAKING OF FLIES! ! !

(Picture of baby and flies swarming about)

PROTECT YOURSELF AND YOUR FAMILY AGAINST FLIES

(Bureau of Health leaflet on flies)

(Picture of a baby in basket screened) 


\section{MILK IS THE ONLY SAFE FOOD FOR INFANTS}

\section{THESE ARE DANGEROUS}

(Colored pictures of)

Corn on cob

Banana

Soda water
Cucumber

Pretzel

Root beer

Tea or coffee
Ice cream cone

Apple

Watermelon

KEEP BABY'S MOUTH CLEAN

WASH SEVERAL TIMES

A DAY

(Picture of baby with

open mouth and hand

pointing to mouth)

\section{DANGER}

These contain opium or equally dangerous drugs

Give no medicine unless ordered by the doctor

U. S. Dept. of

Agriculture

Farmer's

Bulletin

No. 393 .

(Wrappers of various dangerous patent medicines commonly given to infants)

These are the most prominent "Killers" in Philadelphia, but there are many others not on this list equally dangerous. 


\section{BATHE YOUR CHILD EVERY DAY}

On hot days sponge off several times

(Colored picture of baby in basin)

(Woman tossing baby)

Don't shake baby up and down to amuse it

Baby needs sleep. Not in a soft feather bed

(Picture of baby asleep)

Clean house

Clean bottles

(Picture of baby in bath)

Clean food, nipples, and baby

Give cool boiled water to drink several times a day

On hot days

dress cool and comfortable

(Picture of baby ready for bath)

Learn how to take care of the baby

Baby needs a bath every day and sponging several times on hot days 


\section{BABY NEEDS 16 TO 20 HOURS SLEEP EVERY DAY}

A quiet room

His own bed

A cool place

No flies

No soft feather mattress

No cooking in room

(Illustrated with photographs)

(Photograph of a cheap ice box)

MILK NOT PROPERLY ICED IS UNSAFE TO USE

MAKE AN ICE BOX FOR YOUR HOME

A wooden box

Bucket

Saw-dust or excelsior

Newspapers

45 cents

\section{SPEAKING OF FLIES}

(Flies swarming)

\section{KILL EVERY FLY}

(A weapon for killing flies constructed from a piece of wire screening tacked to a wooden handle)

MAKE ONE OF THESE FOR EVERY ROOM IN THE HOUSE 


\section{BABY LOGIC}

Warm weather causes poor, warm, or dirty milk to spoil

Spoiled milk and babies do not agree

The wrong food, or food wrongly prepared, causes sick babies

Dirt, flies, and foul air cause sickness

More babies die during the summer than the winter

Get pure, clean, cold milk and keep it so

Learn how to feed the baby

Get plenty of fresh air

Avoid dirt and flies

\section{BOTTLE FEEDING IS DANGEROUS IF NOT DONE EXACTLY RIGHT}

Don't use any but clean, fresh milk

Don't buy milk from any dealer who does not keep his milk, store, bottles, and cans clean

Don't buy milk that is exposed to flies and dust

Don't buy milk in open cans and pitchers-use milk bottles

Don't let milk remain for hours on door step-place immediately on ice

Don't use left-over milk-use a fresh bottle for each feeding

Circular (English and Yiddish)

Care of the baby in hot weather

Take one home and read it

When baby is sick telephone City Hall, Room 580 or tell any policeman 


\section{CLEAN NURSING BOTTLES}

It is dangerous for the baby's milk to touch anything that is not perfectly clean

As soon as the baby's bottle is empty do these three things:

I. Wash it out first with cold water

2. Then wash it out with hot water and borax or soda (a teaspoonful of borax or soda to a pint of water)

3. Place the bottle upside down on a clean shelf

Wash out bottles with boiling water just before filling with milk

IS YOUR BABY OF NORMAL WEIGHT?

Does he show a natural, healthy increase from week to week?

WEIGHT OF A NORMAL BABY

Age

At birth

I mo.

$2 \mathrm{mo}$.

$3 \mathrm{mo}$.

$4 \mathrm{mo}$.

$5 \mathrm{mo}$.

$6 \mathrm{mo}$.

$7 \mathrm{mo}$.

$8 \mathrm{mo}$.

$9 \mathrm{mo}$.

Io mo.

I I mo.

I2 mo.

Length
I9.5 in.
20.5 in.
21. in.
22. in.
23. in.
23.5 in.
24. in.
24.5 in.
25. in.
25.5 in.
26. in.
26.5 in.
27. in.

Weight

$7 \mathrm{lb}$.

$7 \frac{3}{4}$ lb.

$9 \frac{1}{2} 1 \mathrm{~b}$.

II $1 b$.

I $2 \frac{1}{2} \mathrm{lb}$.

I4 $\mathrm{lb}$.

I5 $\mathrm{lb}$.

I6 $\mathrm{lb}$.

I7 $\mathrm{lb}$.

I8 $1 \mathrm{~b}$.

I9 $\mathrm{lb}$.

$20 \mathrm{lb}$.

2 I $1 \mathrm{~b}$.

HAVE YOUR BABY WEIGHED AT LEAST ONCE A MONTH 


\begin{tabular}{ccc} 
DEATH RATE AT EACH AGE PER \\
\multicolumn{4}{c}{ (U. S. Census } & I890-I900) \\
Age & \multicolumn{2}{c}{ Death Rate } \\
I890 & I900 \\
Under I year & 205.8 & I65.4 \\
I- 2 years & 84.9 & 46.6 \\
$5-9$ years & 7.3 & 5.2 \\
I0-15 years & 3.8 & 3.3 \\
$25-30$ years & 9.9 & 8.6 \\
$45-50$ years & 16.5 & I5.2 \\
60-65 years & 32.8 & 35.1 \\
$70-75$ years & 64.5 & 75.2 \\
80-85 years & 144.6 & I65.8 \\
$90-95$ years & 260. & 339.2 \\
95 and over & 347.1 & 418.
\end{tabular}

One electric sign was used displaying terse sentences referring to the milk question and infant feeding, and numerous other signs contained such axioms as:

\section{TOTAL MORTALITY HAS STEADILY DECREASED ARE THE BABIES GETTING THEIR SHARE?}

\section{INFANT MORTALITY IS THE MOST SENSITIVE INDEX WE POSSESS OF SOCIAL WELFARE}

\section{IT IS THE BUSINESS OF THE MUNICIPALITY TO SEE THAT YOU OBTAIN PURE, CLEAN, FRESH MILK \\ IT IS THE BUSINESS OF THE PEOPLE TO SEE THAT THEY KEEP MIL $\bar{K}$ PURE, CLEAN, AND FRESH}


IT IS NOT THE BABIES BORN BUT THE BABIES SAVED THAT COUNT

THE BUSINESS OF REARING BABIES MUST BE CLASSED AS AN "EXTRA HAZARDOUS OCCUPATION"

90 PER CENT OF THE BABIES DYING OF DIGESTIVE TROUBLES ARE BOTTLE-FED. WHY?

BABIES DIE FROM THE HEAT OF SUMMER BECAUSE THE HEAT SPOILS THE MILK AND MAKES IT UNFIT TO GIVE TO THE BABY

HEAT BREEDS DISEASE GERIMS IN THE MILK KEEP THE MILK COOL

\section{NURSE YOUR BABY}

IF IT SEEMS TO YOU THAT YOUR BREAST MILK DOES NOT AGREE WITH THE CHILD OR YOU HAVE NOT ENOUGH MILK CONSULT YOUR DOCTOR

HE MAY BE ABLE TO CORRECT THE WRONG AND SAVE YOUR BABY 


\section{BABIES UNDER ONE YEAR OF AGE DIED LAST YEAR HALF OF THESE DIED DURING THE SUMMER AT LEAST HALF OF THESE COULD HAVE BEEN SAVED WILL YOUR BABY BE AMONG THIS YEAR'S LIST?}

In connection with this exhibit the Louisville Babies' Milk Fund Association sent a set of photographs and charts illustrating the work of the association; a model of a milk bottle bank; a carrier for milk bottles; and lantern slides illustrating the work of the association.

The Department of Health of the city of Chicago sent charts and test samples showing the control of the milk supply in Chicago; photographs showing some of the conditions met in the handling of milk; copies of ordinances and rules; and charts showing local epidemics of typhoid fever due to milk infection.

The Warelands Dairy Training School located at Norfolk, Massachusetts, sent photographs illustrating the various courses given at the school.

\section{Section 21-Plate XXXV}

Exhibit of Record Forms and Instruments in Use by Various Cities in Milk Inspection Work

The various forms and records used by the following cities in connection with the taking of milk samples for laboratory examination, were contributed:
1. Baltimore, Maryland
2. Boston, Massachusetts
3. Buffalo, New York
4. Chicago, Illinois
5. Cleveland, Ohio
6. Los Angeles, California
7. Montclair, New Jersey
8. New York, New York
9. Philadelphia, Pennsylvania
10 San Francisco, California.

The New Jersey State Board of Health sent samples of their forms and records. The Buffalo Board of Health sent two models of milk cans, one of which was a type approved by the Board of Health, the other being a type which had been condemned by them. A few other sanitary milk buckets and shipping cans were shown.

Representatives from the Division of Milk Inspection of the Bureau of Health of this city were in attendance ready to explain the methods of milk inspection as practised in this city. 


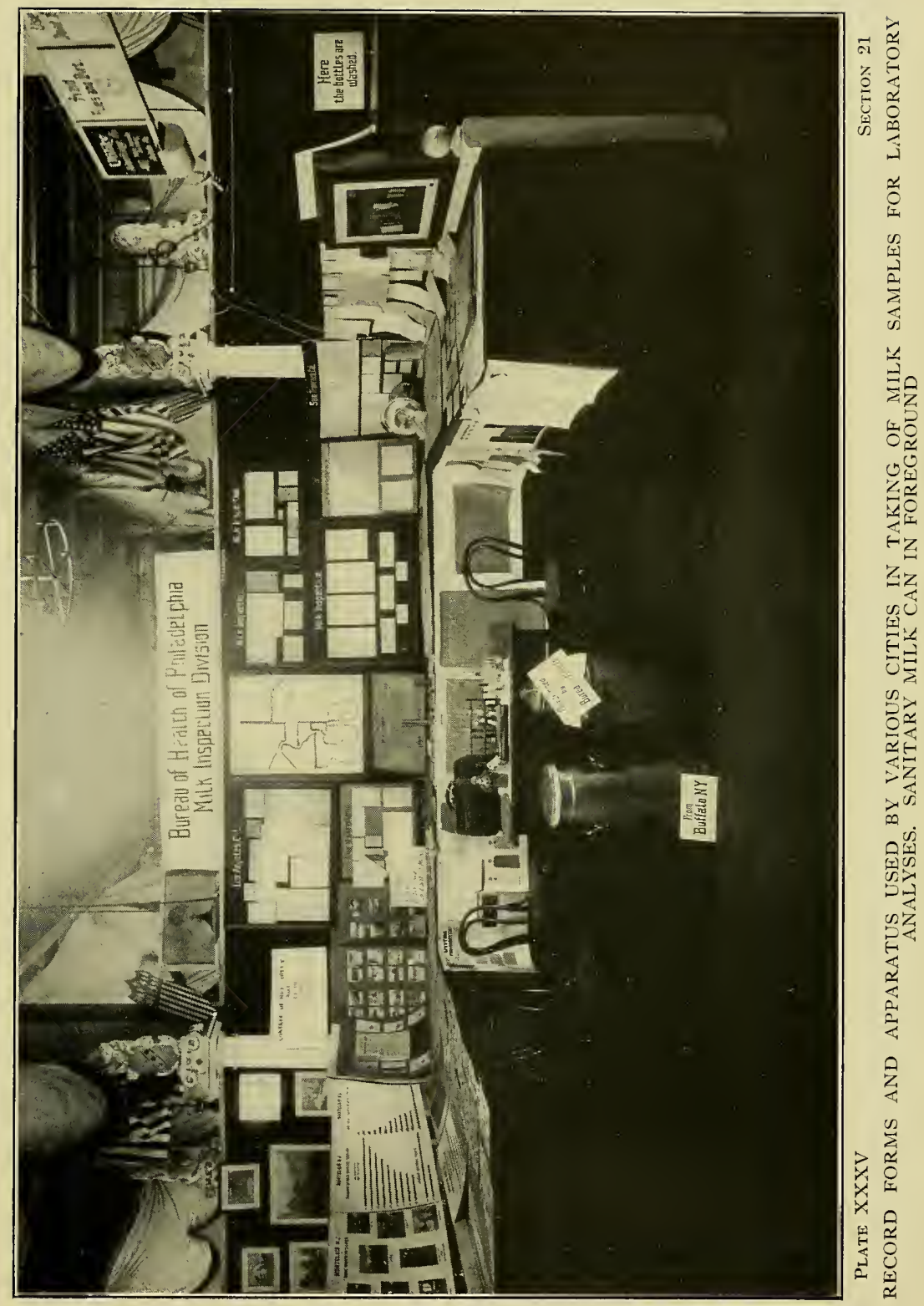





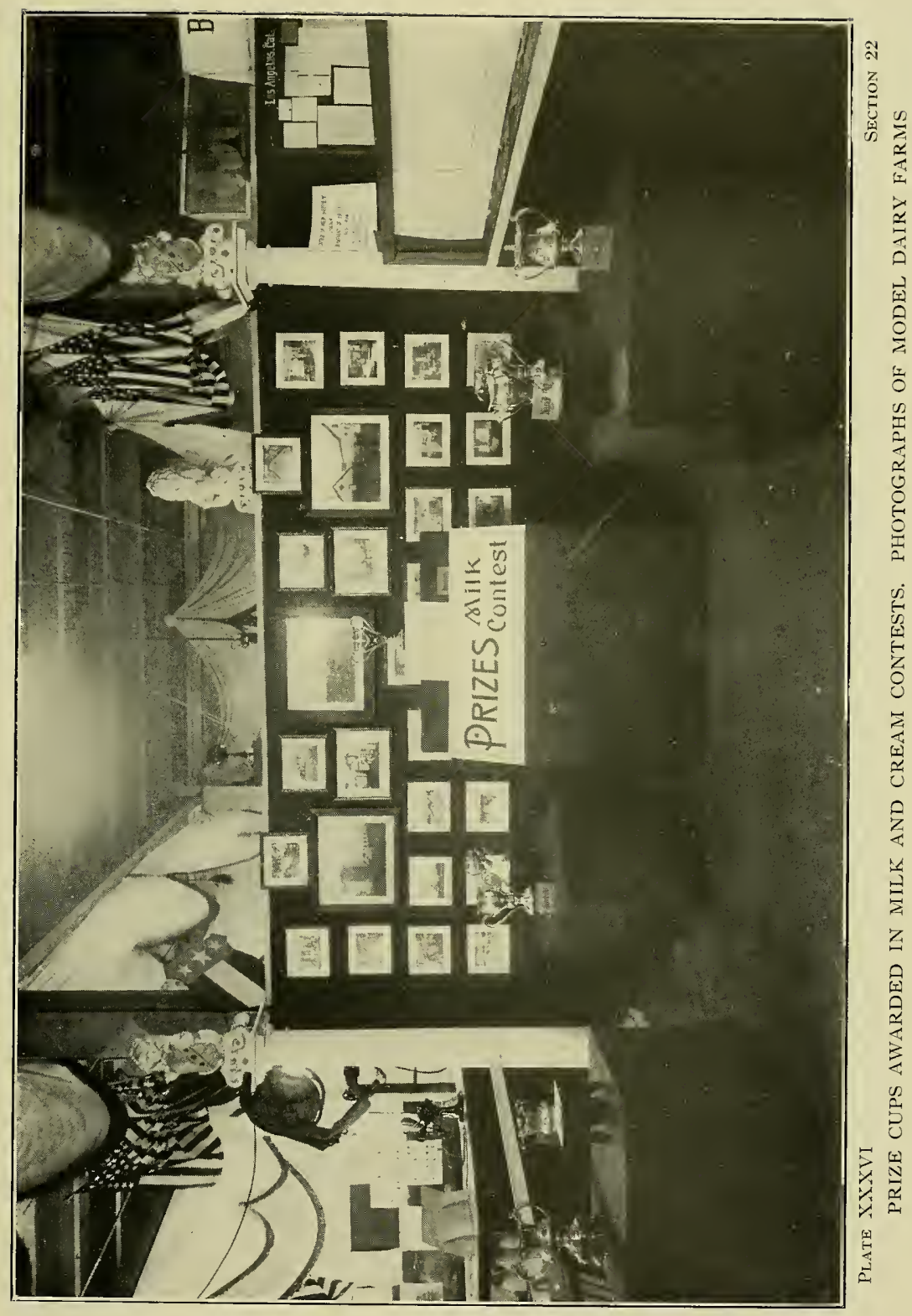





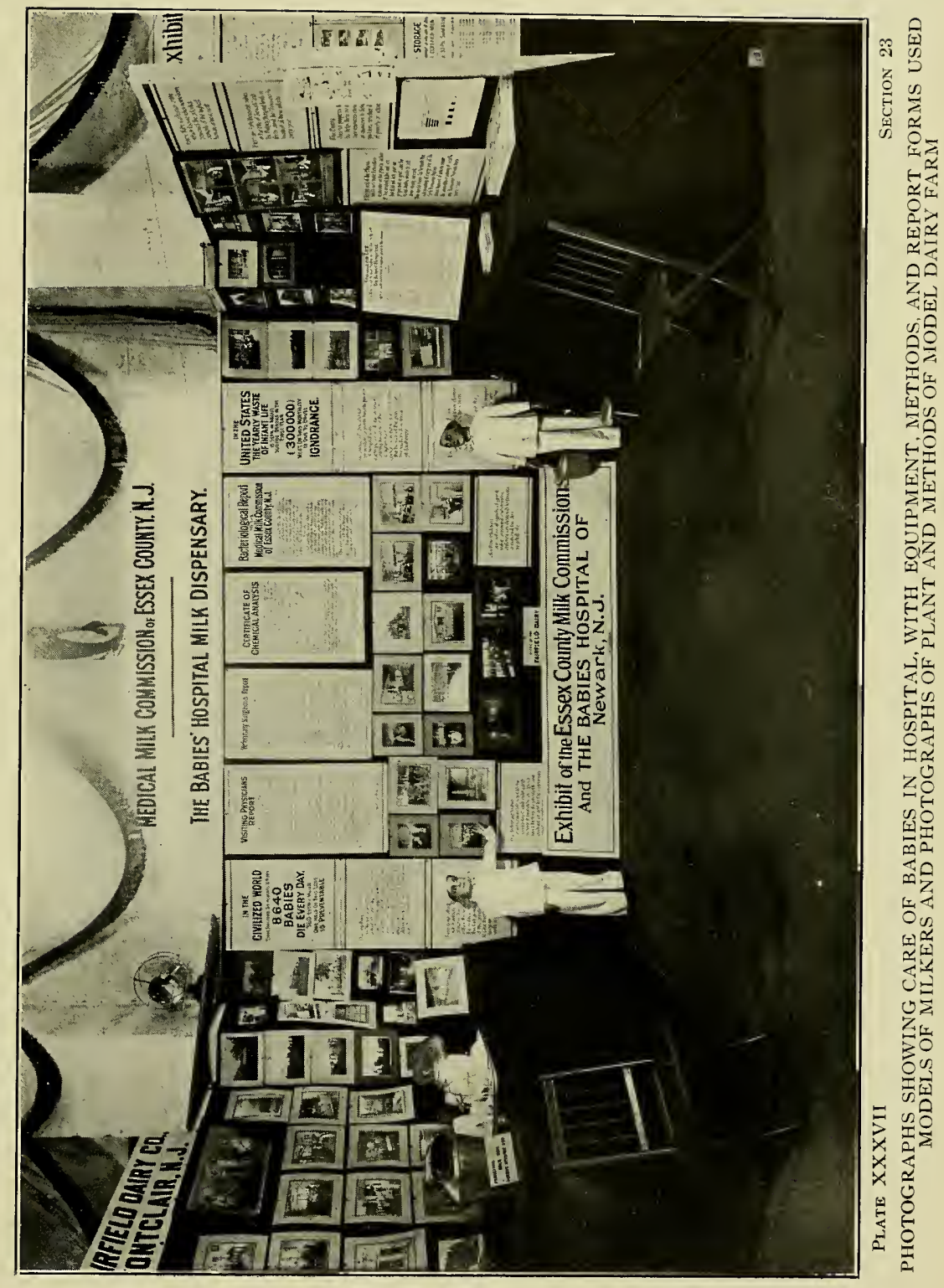





\section{Section 22-Plate XXXVI \\ Exhibit of Prizes in Milk Contests}

This section was used for the purpose of displaying the various cups to be awarded in the certified milk and cream contest and in the market milk and cream contest. The cups were donated by the Philadelphia Pediatric Society. On the walls of this section were hung photographs of model dairy farms.

\section{Section 23-Plate XXXVII \\ Exhibit of the Medical Milk Commission of Essex County, New Jersey; and the Babies' Hospital of Newark, New Jersey}

In this booth were shown numerous photographs of the plant and methods of the Fairfield Dairy Company, Montclair, New Jersey, and of the Babies' Hospital of Newark, New Jersey.

Models about four feet in height were shown representing the milkers employed by the Fairfield Dairy Company. They were dressed in white milking suits and caps, and carried the most approved type of small-mouthed milk pails and metal milking stools.

Samples of charts and score cards in use in the Babies' Hospital were displayed and trained nurses from the hospital were in attendance to give explanations and answer questions. Among the charts hung in this section were some reading:

1. The mother's sorrow in the early death of her puny infant should stimulate vigorous and humane agencies which will prevent such tears and deep grief. We should provide air, sunlight, water, food, and knowledge which will permit other babies to utilize the life to which they have a natural birthright

2. There is no other material out of which we can fashion citizens than the baby, either those now with us or the babies yet unborn. Out of this fact grow two civic duties of the greatest importance, namely

To give them at the outset a sound body

And later to furnish them with a sound mind

3. The intrinsic value of a human life should be recognized and estimated before it unfolds 4. or ripens; long before it can work or endure or add to the common weal or welfare In the United States

The yearly waste of infant life is seen In about 300,000 deaths in the first year $(300,000)$

Most of this mortality is due to cruel Ignorance

5. One ounce of additional prevention is worth twenty pounds of hospital cure. $90 \%$ of the sickness among the infants of the poor is due to ignorance. Ignorance is never removed from the homes of the poor except through instruction given through philanthropy

6. The infants of the poor are found among three classes of parents which have been defined as:

\section{God's poor}

The devil's poor

Poor devils

The Babies' Hospital is no respecter of these babies. They are all human, innocent and worthy

7. Healthy children are national assets of great value. Unsound, defective children are destined to become a national burden in adult life

8. Wise charity does not pauperize the poor, but helps them by adding to their resources enough money or assistance to solve the problem, whether it be one of poverty or sickness. 


\section{Section 24-Plate XXXVIII}

Exhibit of the American Association of Medical Milk Commissions

The material shown in this section consisted of:

1. Numerous photographs of dairy farms producing milk which is being certified by commissions belonging to the association

2. Charts showing the purpose of the organization

3. Charts showing the growth of the milk commission idea

4. Charts showing the results of four years' work

5. Map showing the location of medical milk commissions in the United States and Canada

6. Collection of sanitary milk utensils and instruments from the Walker-Gordon Laboratory Company, used in shipping and delivering milk

7. Display of apparatus used by the Walker-Gordon Laboratory Company in the modification of milk.

\section{SECOND FLOOR EXHIBITS}

On this floor at the front of the building was located the executive office, where the committee on arrangements in general made its headquarters, with the secretary actively in charge. The special publicity agent and her stenographer also did most of their work here, and, of course, all officers and committees used the office for consultation and the general transaction of business incident to the installation of the exhibits and the management of the exhibition.

\section{Section 25-Plates XXXIX and XL}

Pathological Exhibit of the Veterinary Department of the University of Pennsylvania and the Pennsylvania State Live Stock Sanitary Board

This exhibit was presided over by skilled attendants who explained to continuous crowds of interested visitors the meaning of the many charts showing chemical tests to detect disease; tuberculosis in cattle; specimens of various parts and organs of animals affected with disease; and slides showing the results of bacteriological examinations of different kinds of milk. A large refrigerator was installed in this section for the purpose of keeping properly the many specimens.

\section{Section 26-Plates XLI and XLII}

Exhibit of the Dairy Division of the Bureau of Animal Industry of the United States Department of Agriculture

This exhibit was deservedly popular because of the splendid collection of large framed photographs shown, with contrasting views hung side by side, depicting the complete story of good and bad production and handling of milk. The photographs in themselves were most interesting and instructive, but were made much more emphatic by the explanations of the special representatives of the Government, who were detailed here throughout the period of the Show.

Numerous views with terse inscriptions were shown for each of the following main topics:

1. Stables for cows

Dirty and dangerous

Clean and safe 








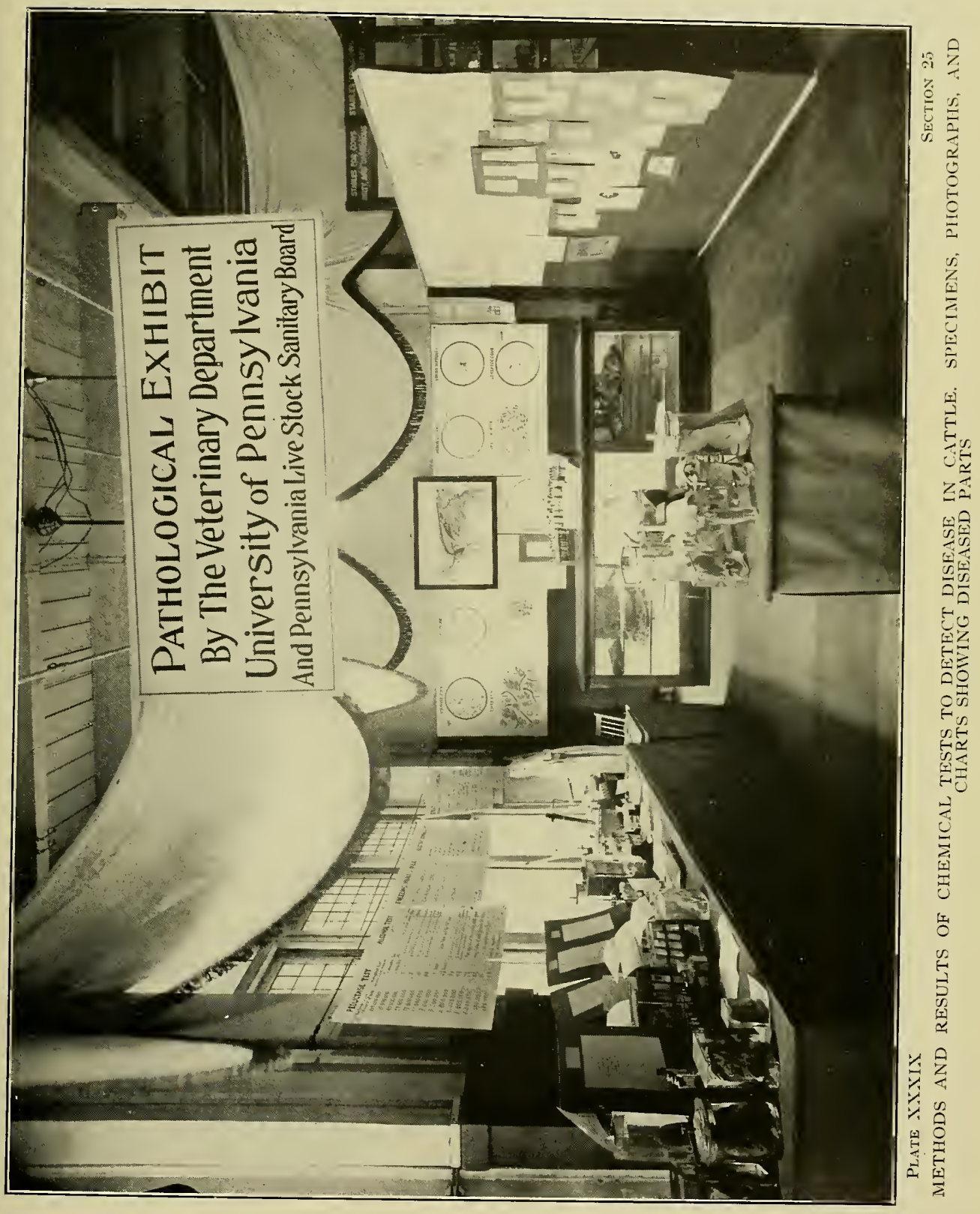





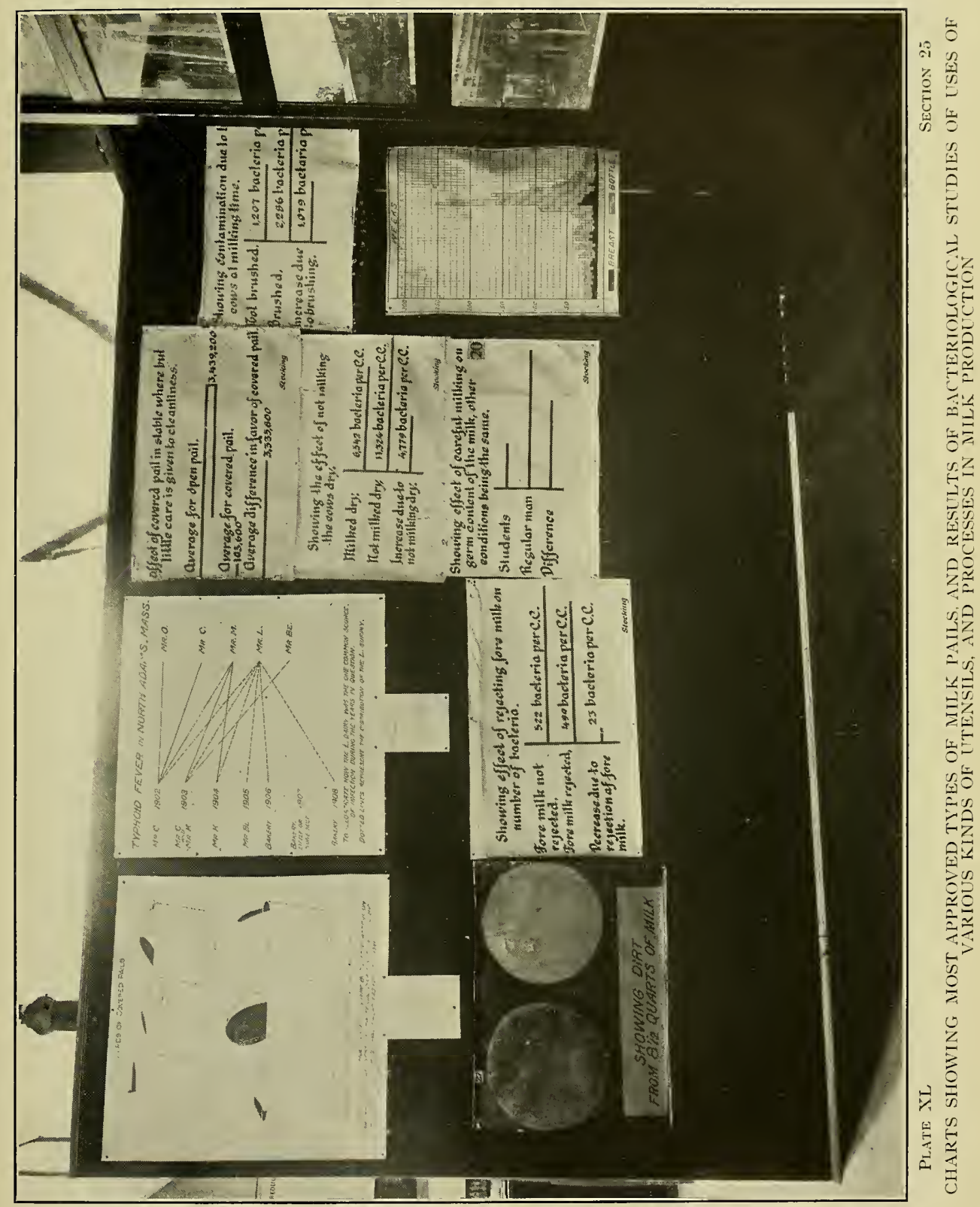





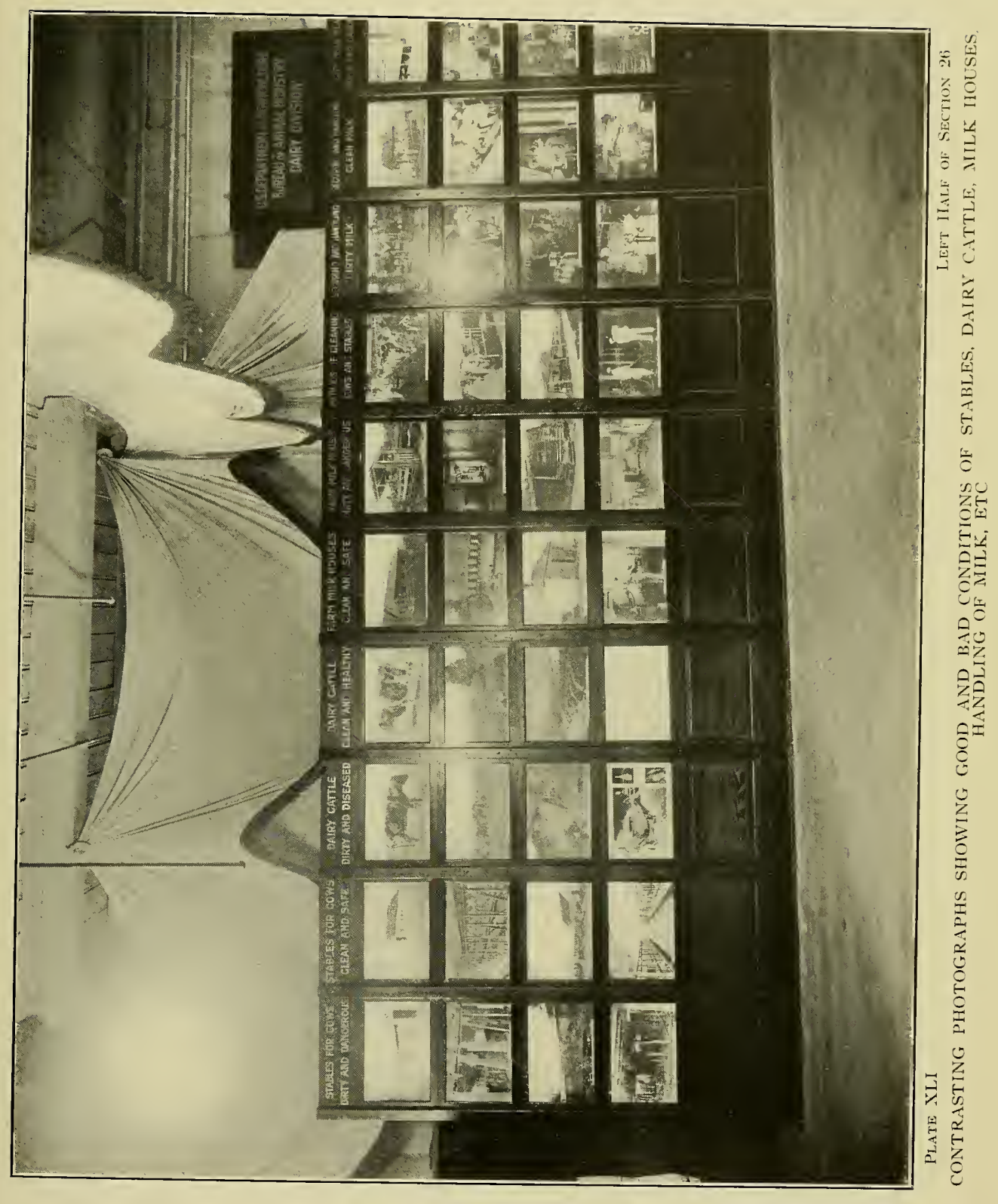





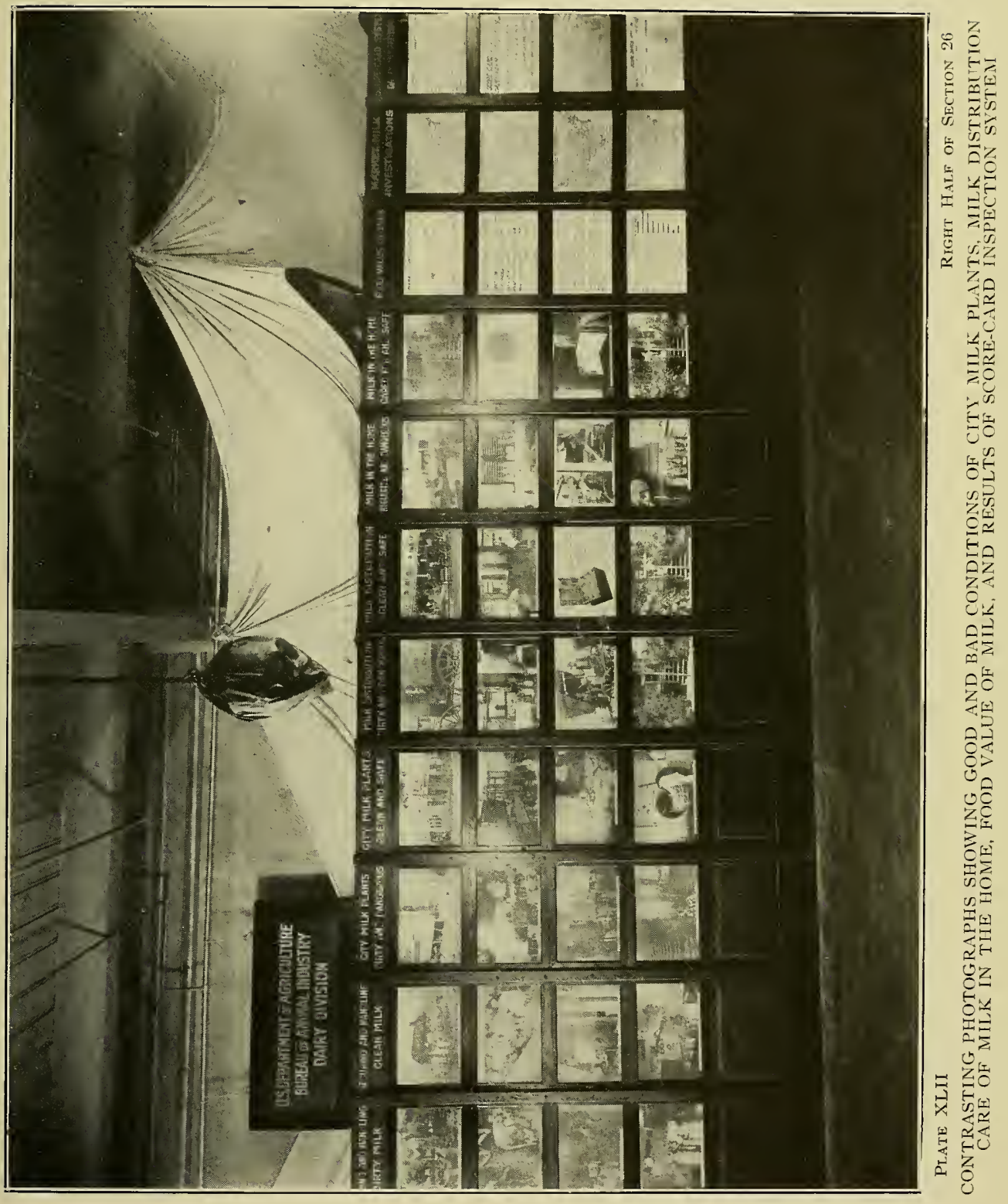





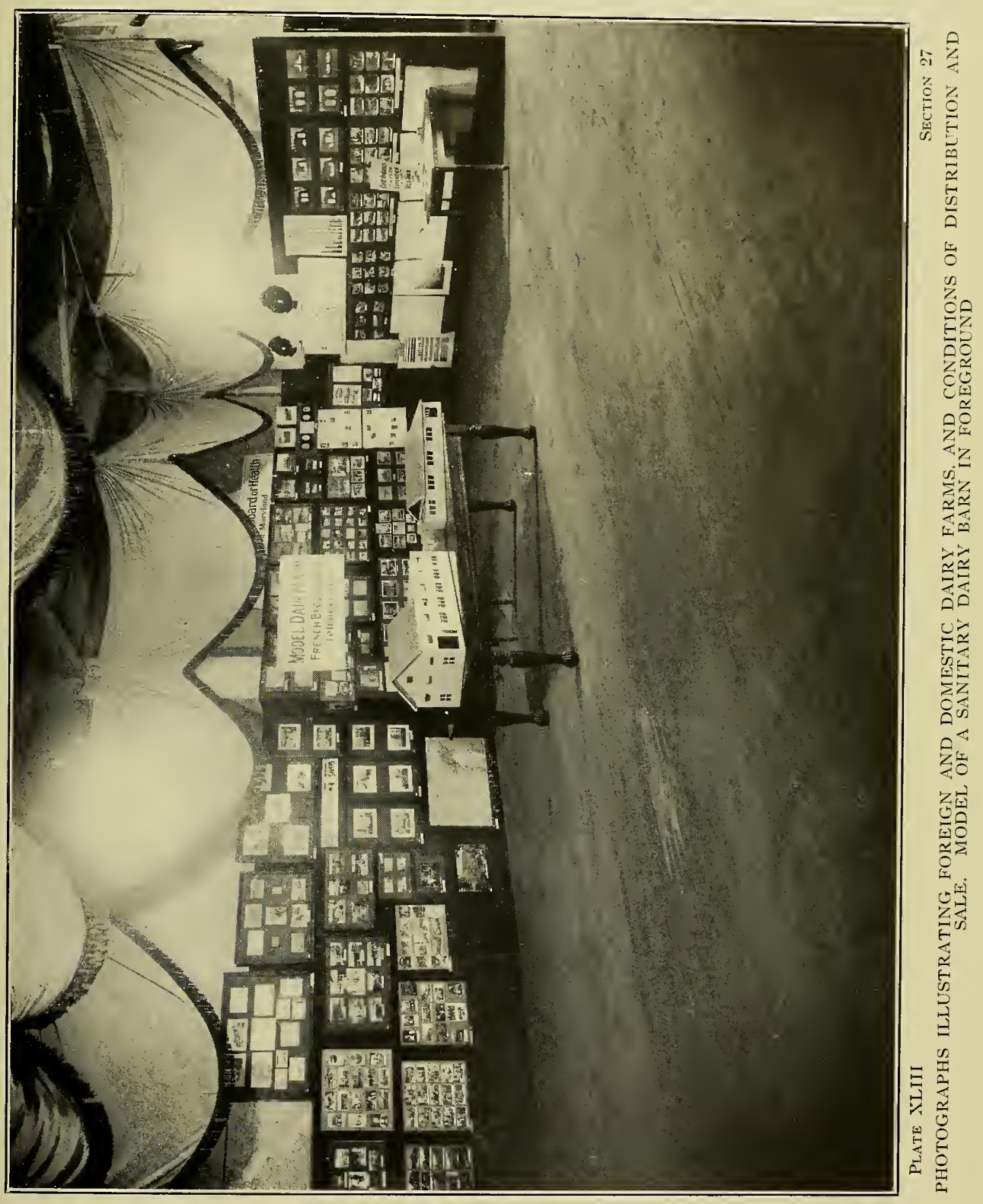



2. Dairy cattle

Dirty and diseased

Clean and healthy

3. Farm milk houses

Clean and safe

Dirty and dangerous

4. Methods of cleaning cow stables

5. Securing and handling

Clean milk

Dirty milk

6. City milk plants

Dirty and dangerous

Clean and safe

7. Milk distribution

Dirty and dangerous

Clean and safe

8. Milk in the home

Neglected and dangerous

Cared for and safe

9. Food value of milk

10. Market milk investigations

11. Score card system of dairy inspection.

\section{Section 27-Plate XLIII \\ Exhibit of the State Board of Health of Maryland}

The wall space of this large section was completely filled with placards, charts, and maps showing dairy farm and milk handling conditions in various countries and cities.

The following placards containing photographs showing foreign conditions were displayed, the number of photographs being given in parenthesis following each subject:

1. Milk animals (26)

2. Milch goats (23)

3. Palermo milk girl with goats and jars-idealized-(colored picture)

4. Milk maids (20)

5. Dairies (14)

6. Methods of handling milk in foreign countries (9)

7. Conveyances for delivering milk (30)

8. Conditions of milk and dairy service ( 16 postal cards)

9. Dairy and laboratory (2)

10. Corner of Havana milk market overlooking the harbor

11. Corner of the Havana milk market by the sea wall overlooking the harbor

12. (1) warehouse for butter; (2) department of refrigerating machinery, steam engine

13. (1) laboratory; (2) refrigerating machinery

14. (1) bottle cleaning department; (2) laboratory.

Placards containing photographs showing domestic conditions were also shown:

1. Work of Philadelphia Pasteurized Milk Society (10). Also samples of pamphlets

2. Philadelphia milk distributing stations (10)

3. Baltimore cow stable, no longer in existence since the passage of the Eisenbrandt ordinance

4. City cow stable, no longer in existence since the passage of the Eisenbrandt ordinance

5. Cow stables $(6)$

6. Cow stables (2)

7. Dairies (5)

8. Interior of dairy

9. Exterior of Quarry Farm dairy (2)

10. Interior of Quarry Farm dairy 
11. Dairy farm-Erahaust Farms (10)

12. Proper means of handling milk

13. Milk receiving stations

14. Goats (4)

15. Different milk products (10)

16. Work of milk commission (5)

17. Oakland, California (5)

18. Pennsylvania State College Dairy School (Several)

19. Ohio State University (19)

20. University of Tennessee (27)

21. Miscellaneous (3)

Charts were shown:

1. Value of farm products. United States, $1859,1878,1889$

2. Value of dairy and total farm products in the United States, 1900

3. Number of cattle to square mile, 1900

4. Milk area, American cities of over 200,000

5. Rural Maryland, 1901, 1902, 1903, 1904

6. Baltimore, $1901,1902,1903,1904$

7. Board of Health of New Jersey. Examination of milk

8. Boston bio-chemical laboratory. Diagram of milk inspection, June, 1905-March, 1906

9. Bacteriological examination of milk

10. Cheese and butter production, 1850-1890

11. Amount of energy and building materials got for one shilling in some typical foods

12. Percentage of nutrients not absorbed in some typical foods

13. Miscellaneous (7)

\section{Maps:}

1. Road map of Maryland

2. Stations from which milk and cream are shipped and territory covered by dairy inspection. District of Columbia Health Department.

In this section was also displayed an interesting model of the dairy barns on the farm of French Brothers and Bauer, Lebanon, Ohio.

\section{Commercial Exhibits}

Floor space measuring about forty-seven by ninety-two feet was devoted to exhibits of a commercial nature. The following firms installed exhibits as noted:

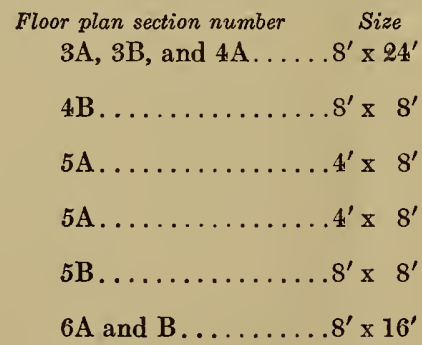

Floor plan section number Size

(B....................

$6 \mathrm{~A}$ and $\mathrm{B} \ldots \ldots \ldots 8^{\prime} \times 16^{\prime}$
Name and kind of exhibit

Mr. Lee H. P. Maynard, 1937 Market Street, an exhibit of a commercial laboratory

Mr. William Kelly, 1204 Pine Street, an exhibit of milk, etc.

Mr. Paul Doering, 1228 North Howard Street, an exhibit of a cooler and aerator

Messrs. Schutte and Koerting, 12th and Thompson Streets, an exhibit of a milk pasteurizer

Independent Milk Dealers, 423 Fitzwater Street, an exhibit of milk, etc.

Mechanical Refrigerating Machine Company, 864 North Franklin Street, an exhibit of an ice machine 
Floor plan section number Size

$7 \mathrm{~A}$ and $\mathrm{B} . \ldots \ldots \mathrm{8}^{\prime} \times 16^{\prime}$

9 A...........8. $8^{\prime} \times 8^{\prime}$

$9 \mathrm{~B} \ldots \ldots \ldots \ldots \ldots 8^{\prime} \times 8^{\prime}$

$10 \mathrm{~A}$ and $\mathrm{B} \ldots \ldots \ldots \mathrm{8}^{\prime} \times 16^{\prime}$

$11 B \ldots \ldots \ldots \ldots 8^{\prime} \times 8^{\prime}$

$12 A$ and $B \ldots \ldots \ldots 8^{\prime} \times 16^{\prime}$

$13 A \ldots \ldots \ldots \ldots \ldots 8^{\prime} \times 8^{\prime}$

$13 B \ldots \ldots \ldots \ldots \ldots 8^{\prime} \times 8^{\prime}$

$14 \mathrm{~A}$ and $\mathrm{B} \ldots \ldots \ldots 8^{\prime} \times 16^{\prime}$

$15 \mathrm{~A}$ and $\mathrm{B} . \ldots \ldots \ldots 8^{\prime} \times 16^{\prime}$

$16 \mathrm{~A} \ldots \ldots \ldots \ldots \ldots 8^{\prime} \times 8^{\prime}$

$17 \mathrm{~A}$ and $\mathrm{B} \ldots \ldots \ldots \mathrm{s}^{\prime} \times 16^{\prime}$

$18 A \ldots \ldots \ldots \ldots 8^{\prime} \times 8^{\prime}$

$18 B \ldots \ldots \ldots \ldots \ldots 8^{\prime} \times 8^{\prime}$

$19 A \ldots \ldots \ldots \ldots \ldots S^{\prime} \times 8^{\prime}$

$19 B \ldots \ldots \ldots \ldots \ldots 8^{\prime} \times 8^{\prime}$

$20 \mathrm{~A}$ and $\mathrm{B} \ldots \ldots \ldots 8^{\prime} \times 16^{\prime}$

$21 \mathrm{~A}$ and $\mathrm{B} \ldots \ldots \ldots 8^{\prime} \times 16^{\prime}$

$22 \mathrm{~A}$ and $\mathrm{B} \ldots \ldots \ldots 8^{\prime} \times 16^{\prime}$
Name and kind of exhibit

Mr. Edward Woolman, 4709 Lancaster Avenue, an exhibit of photographs of a pasteurizer

Caloris Manufacturing Company, 2110 West Allegheny Avenue, an exhibit of Caloris bottles

Dairy Specialty Company, West Chester, Pennsylvania, an exhibit of a mechanical milker, etc.

Charles H. Phillips Company, New York City, an exhibit of milk of magnesia

Root Dairy Supply Company, West Grove, Pennsylvania, an exhibit showing filler and capper combined, dairy-sized cooler, milk pails, etc.

P. E. Sharpless Company, 813 North 11th Street, an exhibit showing shipping arrangements for butter; an exhibit of butter itself; cheese, ice cream; and evaporated milk for ice cream

Single Service Package Corporation of America, 71 Broadway, New York City, an exhibit of paper bottles

Messrs. S. R. and S. W. Kennedy and Company, 28 South Water Street, an exhibit of cheese, butter, and case evaporated and condensed milk

Mr. Samuel Shapiro, 638 North Franklin Street, an exhibit of a cooler adapted for use by farmers, milk can covers of various designs, an improved ice ring for the tops of cans, an improved pasteurizer and cooler, an improved can

The Crown Cork and Seal Company, Baltimore, Maryland, an exhibit showing a milk bottle corking machine

Kensington Engine Works Company, Beach and Berks Streets, an exhibit showing an apparatus for disinfecting or sterilizing milk bottles by steam

Abbott's Alderney Dairies, 1823 Filbert Street, an exhibit of milk and milk products, photographs of plant, etc.

Dairymen's Supply Company, Baltimore Avenue and P. R. R., Lansdowne, Pennsylvania, an exhibit of dairy supplies

West Disinfecting Company, 1303 Race Street, an exhibit of liquid soap for washing hands, of formaldehyde generators, of chloronapthaleum (a disinfectant) and of creolin

Achor Chocolate Manufacturing Company, 1338 Cherry Street, an exhibit of milk chocolate and chocolactine

The Underwriters Company (Mr. Volkert O. Lawrence, President), 13th and Walnut Streets, in the name of the American Milk Improvement Company, an exhibit of Eversweet Milk

The Supplee Alderney Dairies, 1118 Jefferson Street, an exhibit of photographs and products, and Fermillac

The J. B. Ford Company, Michigan (W. E. Ratz, 415 Bulletin Building, Philadelphia), an exhibit showing Wyandotte powder for washing bottles and pans, etc.

Exhibition lecture hall, Creamery Package Company, 1907 Market Street, an exhibit of a pasteurizer. 

APPENDICES 


\section{APPENDIX A}

\section{Program of the Milk Show. Folded Size: 6 Inches by 11 Inches}

Note:-For reproduction of first, or cover, page see plate II, opposite p. 16. The fourth page contained the programs of the Conference of State and Municipal Health Officers and the Dairy Institute. These programs are reprinted as appendices B and C respectively, because they were also printed separately from the Milk Show program. 
MOVING-PICTURE DEMONSTRATIONS AT THE CLOSE OF EACH SESSION AFTERNOON AND EVENING LECTURES AND DEMONSTRATIONS

\title{
OPENING DAY-SATURDAY, May 20
}

\author{
3 P. M.
}

Presiding Officer, DR. C. J. HATFIELD, Vice-Chairman of the Executive Committee of the Philadelphia Milk Show

ADDRESS OF WELCOME: Hon. John E. Reyburn Mayor of the City of Philadelphia

THE PRESENT CONDITION OF THE MILK SUPPLY OF THE CITY OF PHILADELPHIA:

Dr. Joseph S. Neff, Director of the Department of Public Health and Charities.

MEANS OF CORREC TING THE DEFECTS IN PHILADELPHIA'S MILK SUPPLY:

Dr. S. McC. Hamill, Chairman of the Philadelphia Pediatric Society Milk Commission.

12.20 P. M.

Dr. H. Brooker Mills.

8 P. M.

Presiding Officer, DR. WARD BRINTON, Physician to the Philadelphia General Hospital THE DISSEMINATION OF DISEASE BY MILK:

Dr. Randle C. Rosenberger, Professor of Bacteriology, Jefferson Medical School.

MILK AS A FOOD: Dr. Lawrence F. Flick, Director of White Haven Sanatorium

THE HOURS OF DELIVERY OF MILK TO THE CONSUMER AND THE CARE OF THE EMPTY MILK BOTTLE: Dr. J. C. Gittings, Instructor in Diseases of Children, University of Pennsylvania.

\section{SUNDAY, May 21 \\ LECTURES IN YIDDISH}

3 P. M.

Presiding Officer, DR. L. W. STEINBACH, Professor of Surgery, Philadelphia Polyclinic and School for Graduates in Medicine

INFANT MORTALITY AND THE MILK QUESTION: Dr. Maurice Goldberg, Member of the Philadel-

CARE OF MILK IN THE HOME: Dr. S. Seilikowitch, Member of the Philadelphia Pediatric Society.

8 P. M.

\section{FOR EMPLOYEES IN DEPARTMENT STORES}

Presiding Officer, DR. JAMES M. ANDERS, Professor of the Practice of Medicine, Medico-Chirurgical Medical School

THE VALUE OF MILK TO THE INDOOR -WORKER: Dr. James H. McKee, Professor of Children's Diseases at Temple University.

MILK PRODUCTS IN RELATION TO HEALTH: Dr. Jesse D. Burks, Director of the Burean of Municipal Research.

\author{
MONDAY, May 22 \\ I2.20 P. M.
}

Dr. Alex. H. Davisson.

$$
3 \text { P. M. }
$$

Presiding Officer, DR. D. J. MILTON MILLER, Member of the American Pediatric Society THE MEDICAL MILK COMMISSION AND ITS PURPOSES: Dr. Henry L. Coit, President of the New

DAIRY EDUCATION AMONGST THE PRODUCERS OF MILK (Lantern Slides): Mr. W. E. Miller, President of the Certified Milk Producers' Association of America.

\section{P. M.}

Presiding Officer, DR. J. T. RUGH, President of the Philadelphia Pediatric Society THE DISEASES OF CHILDREN TRACEABLE TO BAD MILK: Dr. Abraham Jacobi, Emeritus Professor of the Diseases of Children, Columbia University, New York.

THE PRODUCTION OF CLEAN RAW MILK: Mr. Stephen Francisco, Ex-President of the Certified Milk Producers' Association of America.

\section{TUESDAY, May 23}

II A. M.

MILK IN COOKING: Miss Edna Klaer, Drexel Institute.

$$
\text { 12.20 P. M. }
$$

Dr. S. W. Newmeyer.

$$
3 \text { P. M. }
$$

Presiding Officer, DR. JAMES TYSON, Emeritus Professor of Medicine, Univ. of Pa. THE CARE OF MILK IN THE HOME: Dr. G. M. Whitaker, In Charge of Market Milk Investigations, Dairy Division, U. S. Department of Agriculture.

THE IMPORTANCE OF PROPER CONTROL IN THE MANUFACTURE OF BUTTER: Dr. Alfred F. Hess, Bacteriological Department, Board of Health, New York City.

$$
8 \text { P. M. }
$$

Presiding Officer, MR. J. PRENTICE MURPHY, Secretary and Superintendent of the Children's Bureau of Philadelphia

MILK SUPPLY OF VILLAGES: Dr. H. W. Conn, Professor of Bacteriology, Wesleyan University.

THE RELATIONSHIP OF MILK TO TUBERCULOSIS IN HUMAN BEINGS: Dr. William H. Park, Chief Bacteriologist of the Department of Health, New York City.

\section{WEDNESDAY, May 24}

I A. M. Under the Auspices of the Civic Club

THE ELIMINATION OF THE FLY (Illustrated): Mrs. R. Tait McKenzie.

$$
\text { II.40 A. M. }
$$

LANTERN SLIDE AND MOVING-PICTURE DEMONSTRATION. 
$12 \mathrm{M}$.

THE VALUE OF INSTRUCTION BY THE VISITING NURSE IN CONNECTION WITH THE CARE OF MILK IN THE HOME: Miss Ellen C. Babbitt, Russell Sage Foundation, New York.

3 P. M.

Presiding Officer, DR. J. C. WILSON, Professor of Medicine, Jefferson Medical School MILK AS A CARRIER OF INFECTION: Dr. E. C. Schroeder, Superintendent Experiment Station, B.

METHODS OF PROTECTING MILK SUPPLIES FROM SOURCES OF INFECTION: Dr. John R. Mohler, Chief of Pathological Division, B.-A. I., U. S. Department of Agriculture.

8 P. M.

Presiding Officer,DR.J.S. NEFF, Director of the Department of Public Health and Charities PASTEURIZATION OF MILK: Dr. M. J. Rosenau, Professor of Preventative Medicine and Hygiene,

SAFEGUARDING THE HANDLING AND DISTRIBUTION OF MILK IN CITIES: Dr. W. A. Evans, Health Officer of the City of Chicago.

\section{THURSDAY, May 25}

II A. M.

MILK IN THE DAILY MENU: Miss Lena Powers, Drexel Institute.

I2.20 P. $M$.

Dr. Waiter S. Cornell.

3 P. M.

Presiding Officer, DR. SAMUEL G. DIXON, Commissioner of Health of Pennsylvania

THE MEANS OF IMPROVING MARKET MILK-CARRIED OUT BY THE UNITED STATES DEPARTMENT OF AGRICULTURE: Dr. G. M. Whitaker, In Charge of Market Milk Investigations, Dairy Division, U. S. Department of Agriculture.

THE INSPECTION OF DAIRY HERDS-WHAT THE INSPECTOR DOES AND WHY HE DOES IT: Dr. J. P. Turner, Chief Milk Inspector of the City of Washington.

\section{P. M.}

Presiding Officer, REV. HERMAN L. DUHRING, Superintendent of City Missions THE RELATIVE VALUE OF MILK AND OTHER FOODS, ESPECIALLY THE ADVERTISED SUBSTITUTES FOR MILK: Dr. David L. Edsall, Professor of Medicine, University of Pennsylvania.

WHAT THE CONSUMER SHOULD DEMAND OF THE MILKMAN: Dr. John Amyot, Health Officer of the City of Toronto, Canada.

\section{FRIDAY, May 26 \\ I2.20 P. M.}

THE ELIMINATION OF THE FLY (Illustrated): Dr. W. N. Bradley.

3 P. M.

Presiding Officer, DR. E. E. GRAHAM, Professor of Diseases of Children, Jefferson Medical College

ICE CREAM AND ITS RELATION TO PUBLIC HEALTH: Dr. Geo. W. Stiles, Bacteriological Chemist of the Bureau of Chemistry, U. S. Dept. of Agriculture.

THE DECEPTIONS PRACTICED IN THE PREPARATION AND SALE OF MILK: Dr. Charles $H$. LaWall, Chemist of the Pennsylvania State Dairy and Food Department.

8 P. M.

Presiding Officer, DR. R. H. HARTE, Surgeon of the Pennsylvania Hospital CONSUMERS' ORGANIZATIONS IN RELATION TO THE MILK OUESTION: Mrs. William Lowell Putnam. Chairman of the Executive Committee of the Massachusetts Milk Consumers' Association.

DANGEROUS PRACTICES IN THE HANDLING OF MILK: Dr. Otto P. Geier, Secretary of the American Association of Medical Milk Commissions.

\section{SATURDAY, May 27}

II A. M.

HOME-MADE ICE CREAM: Mrs. Anna B. Scott, of the North American.

$$
\text { I2.20 P. M. }
$$

Dr. Theo. LeBontillier.

3 P. M.

Presiding Officer, MR. W. W. PHILLIPS, of the Tri-State Milk Producers' Association HOW TO PRODUCE HIGH QUALITY MILK: Dr. George M. Whitaker, In Charge of Market Milk Investigations, Dairy Division, U. S. Department of Agriculture.

INSPECTION OF DAIRY HERDS AS INSTALLED BY THE STATE LIVE STOCK SANITARY BOARD: Dr. C. J. Marshall, Veterinarian of the State of Pennsylvania.

\section{AWARDING OF PRIZES}

The cups given as prizes for the Certified Milk and Cream Contest are donated by the Milk Commission of the Philadelphia Pediatric Society, and the cups for the Market Milk and Cream Contest by the Philadelphia Milk Exchange.

\section{P. M.}

Presiding Officer, MR. J. A. VOGLESON, Chief of the Bureau of Health THE JOURNEY OF MILK FROM THE COW TO THE CONSUMER: Mr. John D. Nichols, President of the International Milk Dealers' Association.

THE DUTY OF THE PUBLIC IN THE CRUSADE FOR CLEAN MILK: Dr. Talcott Williams, LL.D.

Special demonstrations of the exhibits daily by the following corps of instructors:

II A. M. to 2 P. M.-Dr. N. F. Bricker, Dr. Mark T. Bowie, Dr. Walter H. Oliver, Dr. Ward Brinton.

2 P. M. to 5 P. M.-Dr. Sidney J. Repplier, Dr. Jacobina S. Reddie, Dr. A. G. Tinney, Dr. Randolph Faries. 7 P. M. to ro P. M.-Dr. Benj. D. Parish, Dr. Marianna Taylor, Dr. J. McPhee Hincken, Dr. Frank Baird. 2 P. M. to 5 P. M. Sunday.-Dr. N. H. Hornstine in Yiddish.

Although the Philadelphia Milk Show has tried to properly censor the commercial exhibits, it cannot hold itself responsible for statements or opinions expressed by commercial exhibitors, nor particularly recommend their products above other similar ones. 


\section{APPENDIX B}

Program of the Conference of State and Municipal Health Officers. Folded Size: $31 / 2$ Inches by 6 Inches

Note:-For reproduction of first, or cover, page see plate II, opposite p. 16.

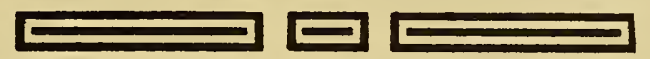

The text of the Conference is the Report of the

Philadelphia Milk Commission, and contemplates a

Discussion of the entire SIILK PROBLEM

MORNING SESSION TEN O'CLOCK

CHARLES B. PENROSE, M. D. PRESIDING

Special Discussion with Relation to

"The Need Of, and the Results from Regulation of Milk Supplies"

To be Opened by

ERNST J. LEDERLE, Ph.D.

Commissioner of Health, New York City

H. H. WILEY, M. D.

Chief of Bureau of Chemistry, United States Department of Agriculture

C. HAMPSON JONES, M. D.

Assistamt Commissioner of Health, Baltimore, Md.

Professor CHARLES H. LaWALL

Chemist, State Food Commission, Pennsylvania

CHARLES J. HASTINGS, M. D.

Medical Health Officer, Toronto, Canada

F. H. STADTMUELLER, ESQ.

Health Officer, Elmwood, Connecticut

GENERAL DISCUSSION

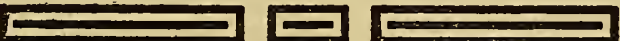

(Second Page) 


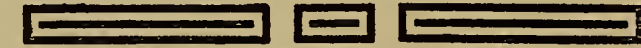

\section{AFTERNOON SESSION}

\section{THREE O'CLOCK}

\section{A. C. ABBOTT, M.D., LL. D. PRESIDING \\ Special Discussion in Relation to \\ "The Development of, and the Practical Application of Milk Laws"}

To be opened by

W. A. EVANS, M. D.

Commissioner of Health, Chicago, III.

JOHN A. AMYOT, M. D. Health Officcr, Ontario, Canada

E. C. LEVY, M. D.

Chief Health Officer, Richmond, Virginia

GEORGE W McGUIRE

Chief, Division of Creameries and Dairies, State

Bnard of Health, Trenton, New Jersey

Prof H. E. VanNORMAN

Professor of Dairy Husbandry. Pennsylvania State

College, Bellefonte, Pennsylvania

WILLIAM GIMPER, V. M. D.

Supervising Inspector, State Live Stock Sanitary

Board, Harrisburg, Pennsylvania

GENERAL DISCUSSION

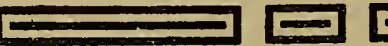

(Third Page) 


\section{APPENDIX C}

Program of the Dairy Institute. Folded Size: 4 Inches by 9 Inches

Note: For reproduction of first, or cover, page see plate II, opposite p. 16.

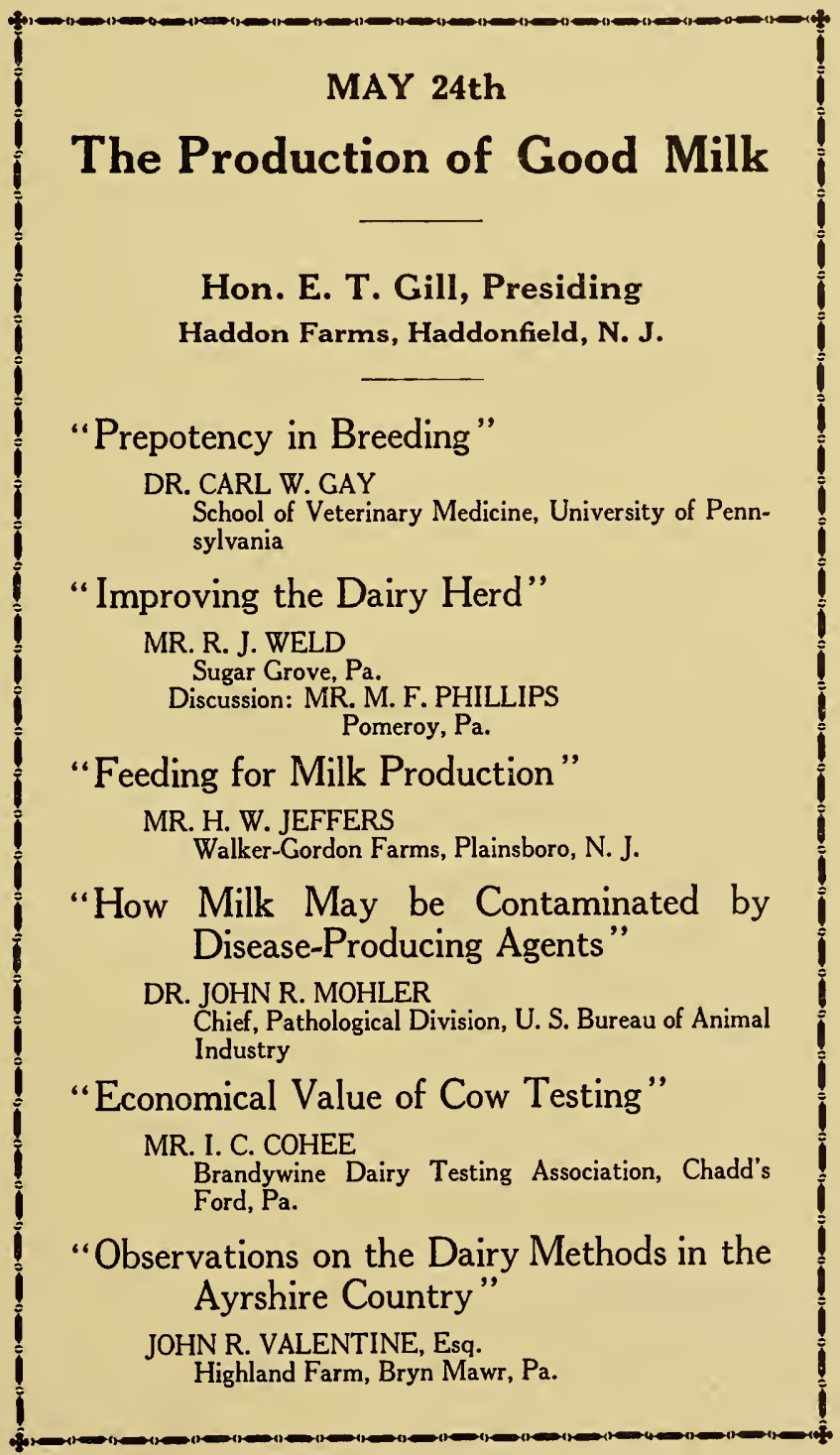

(Second Page) 


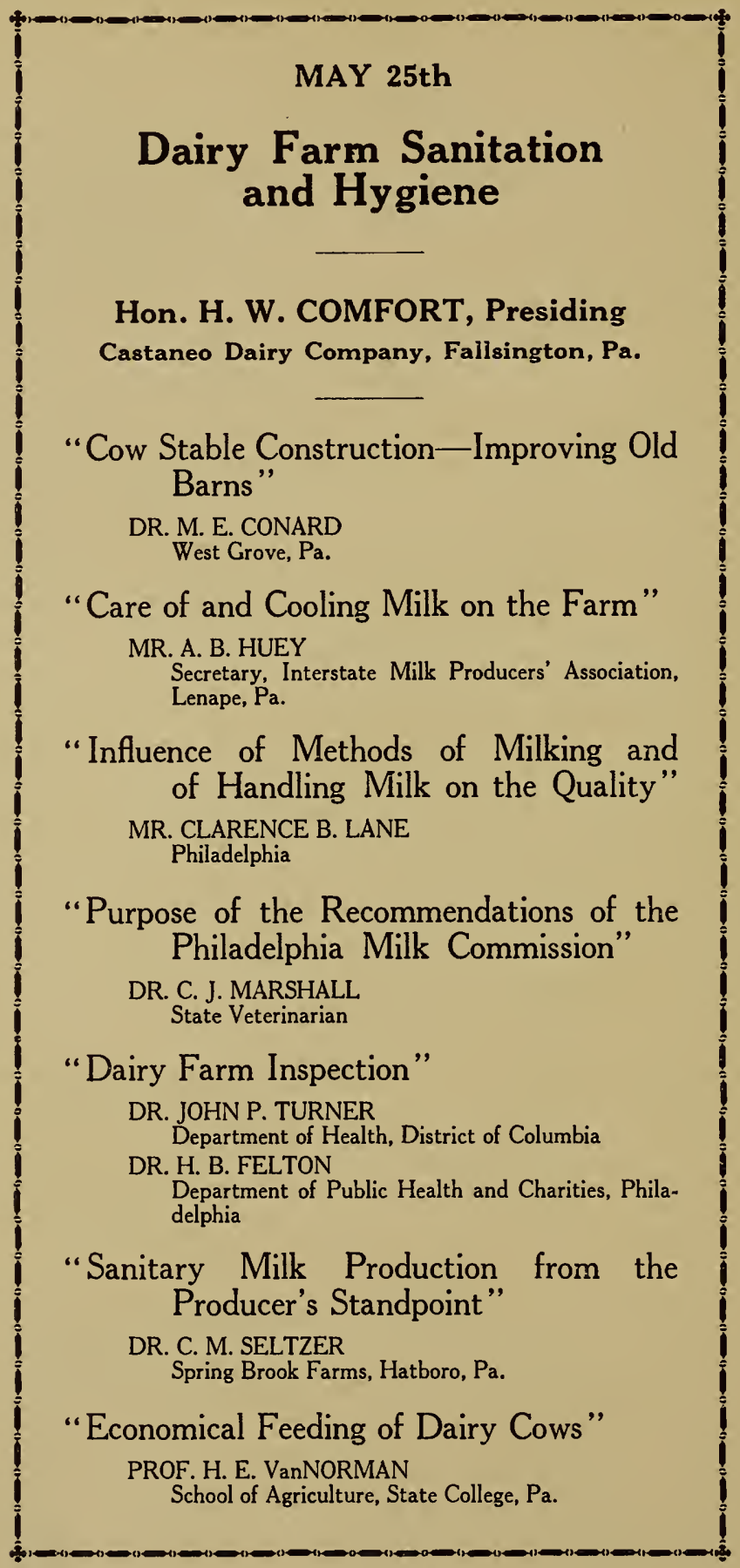

(Third Page) 


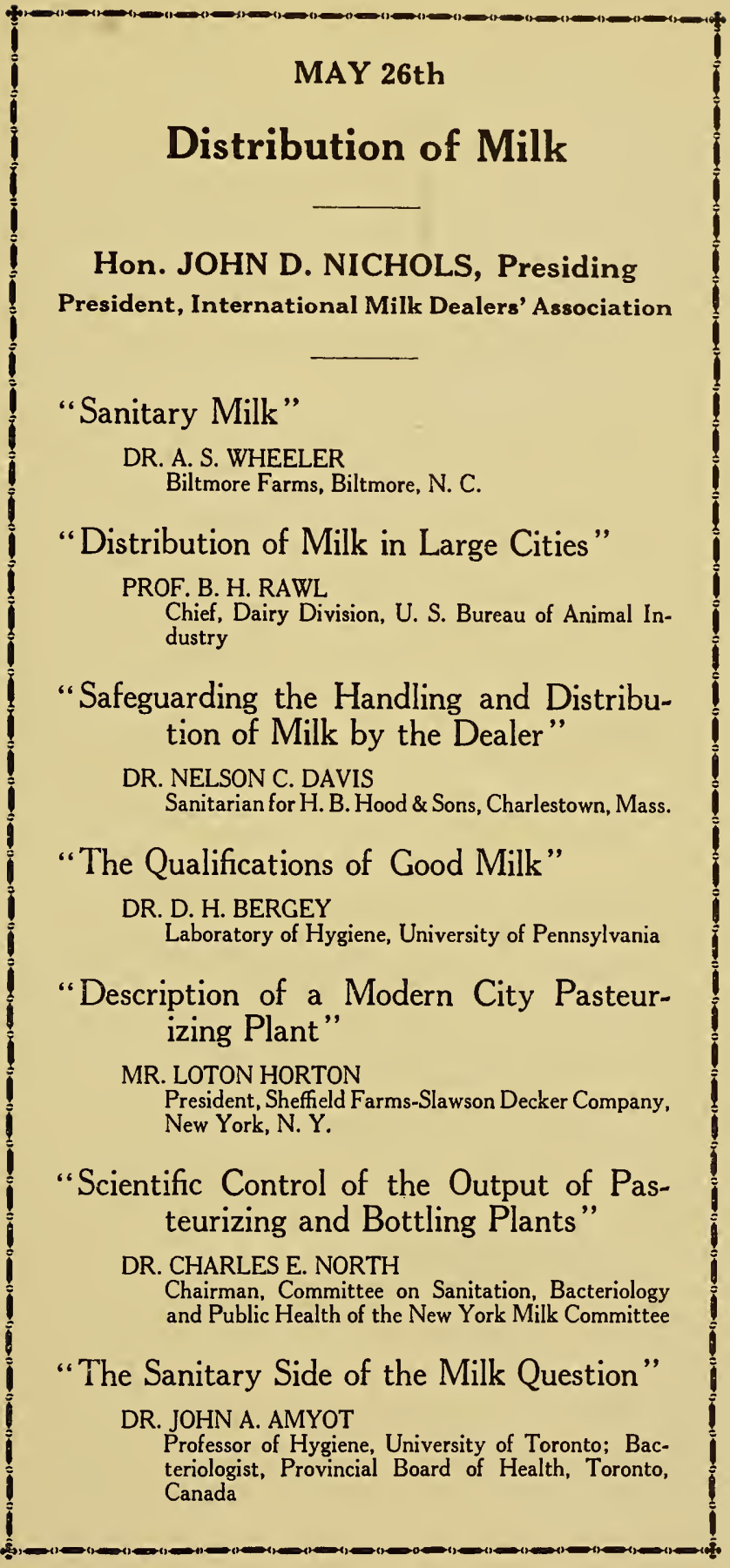

(Fourth Page) 


\section{APPENDIX D}

Educational Leaflets. Folded Size: 5 Inches by 8 Inches

\section{0}

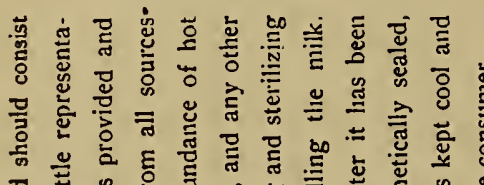

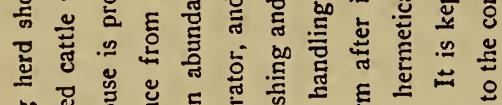

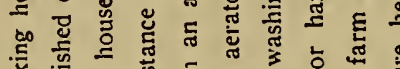

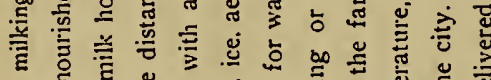

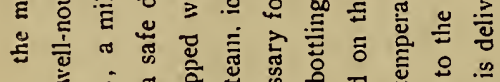

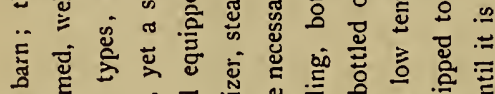

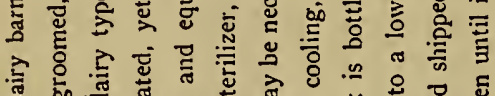

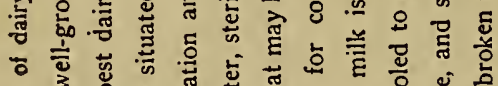

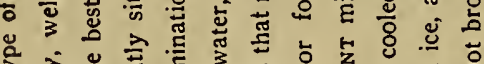

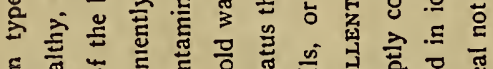

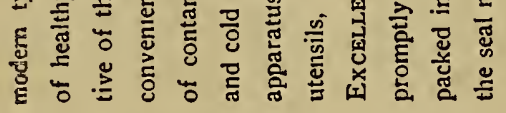

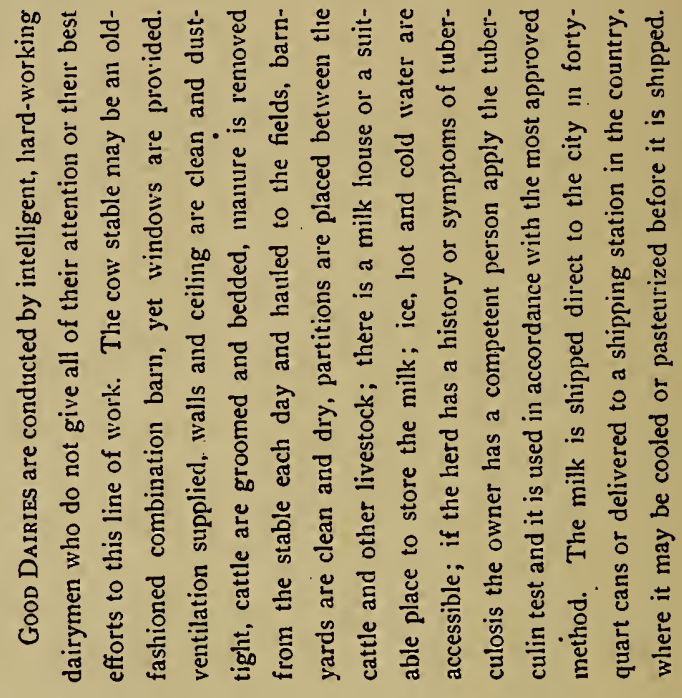

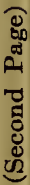

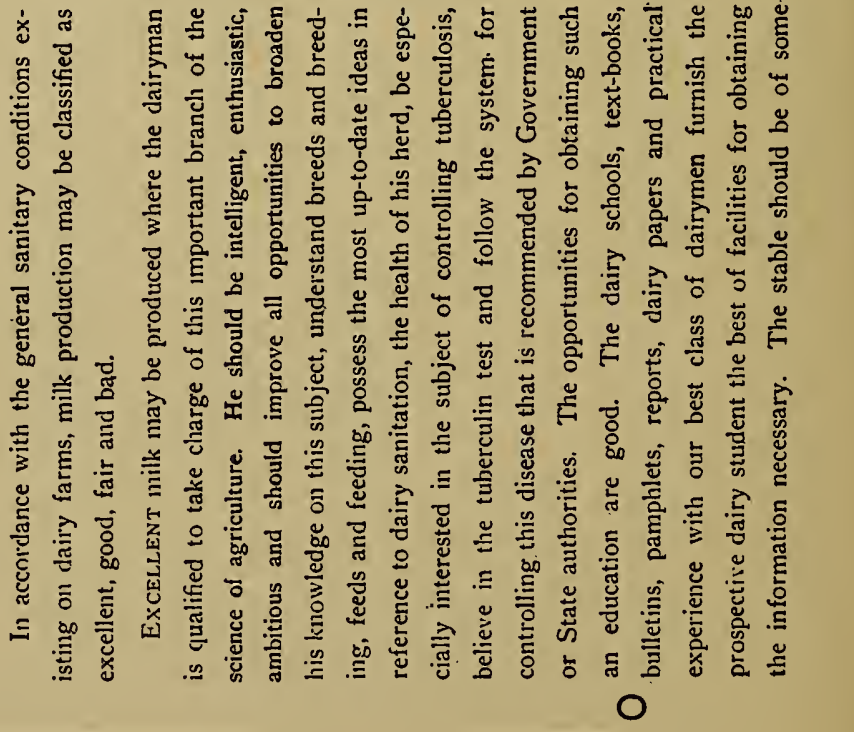




\section{0}

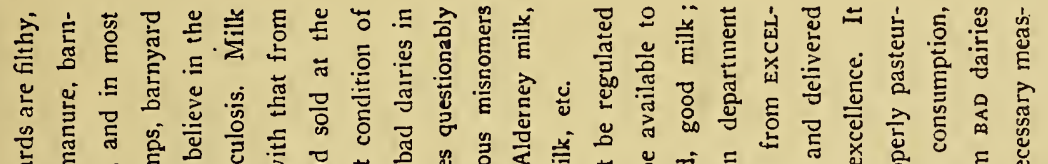

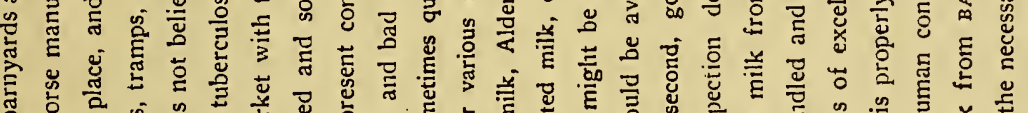

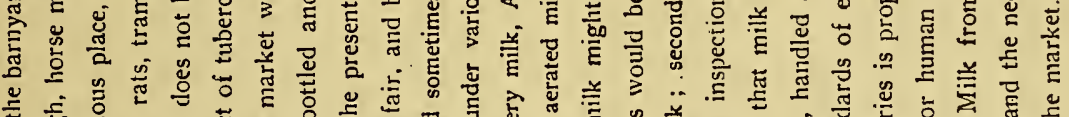
至 它

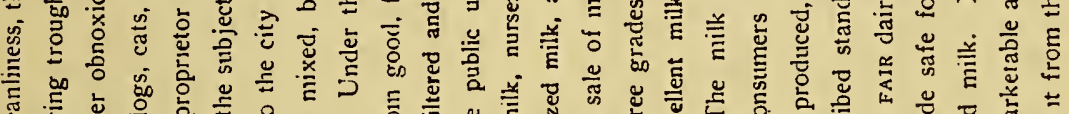

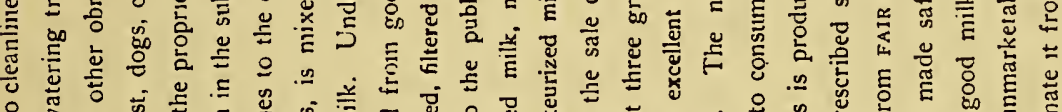

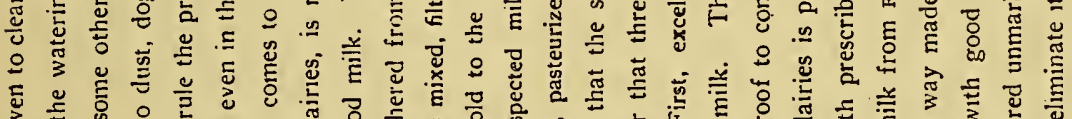

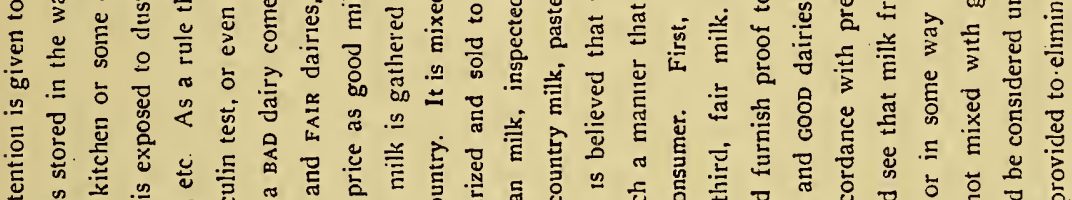

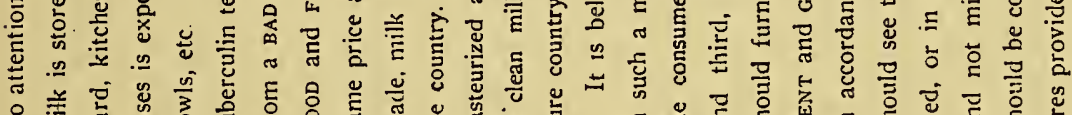

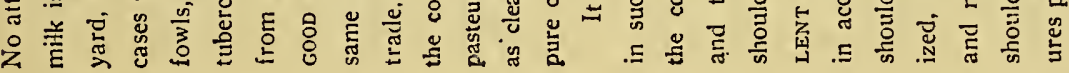

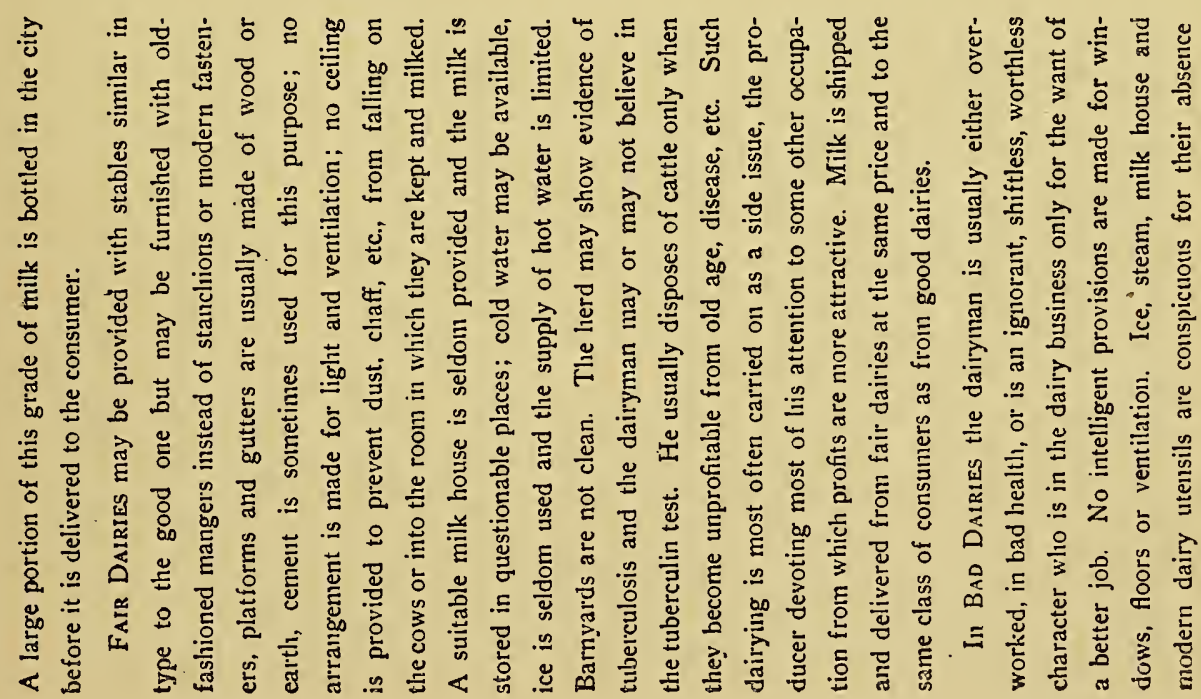

$$
\text { O }
$$$$
\text { O }
$$ 


\section{0}

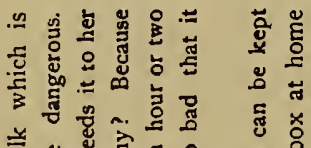

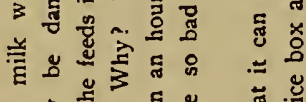

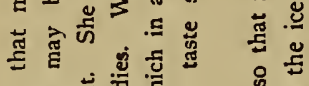

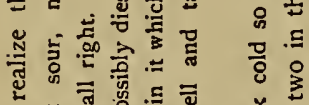

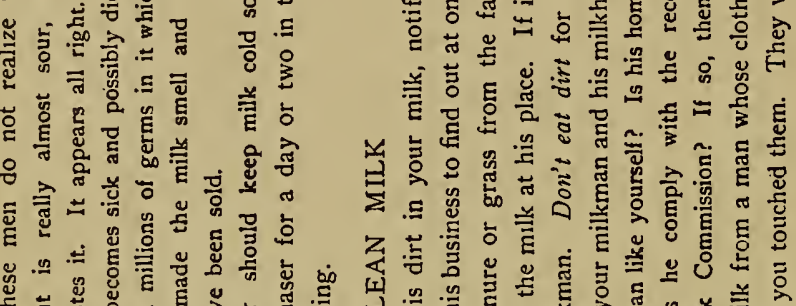

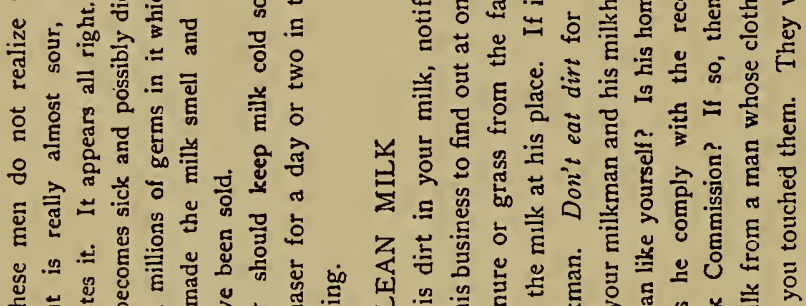

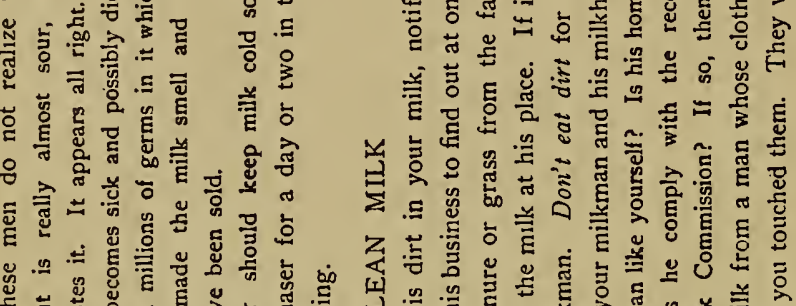

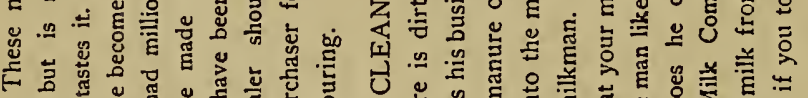

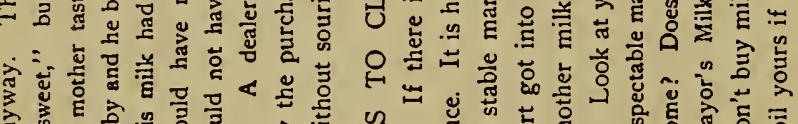

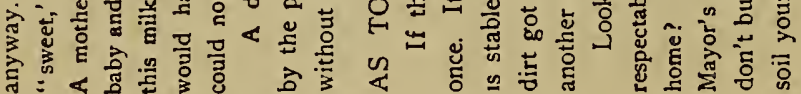

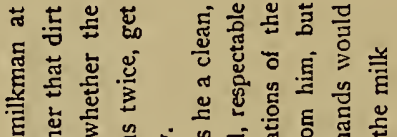

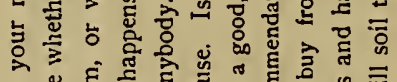

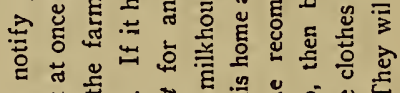

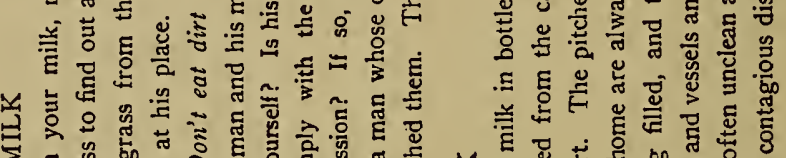

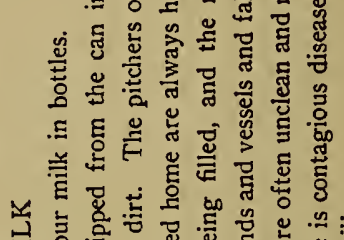

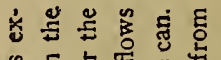

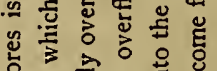

을.

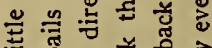

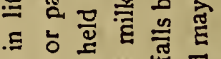

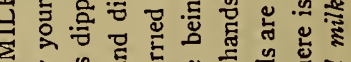

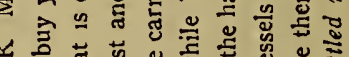

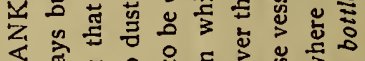

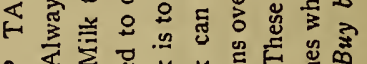

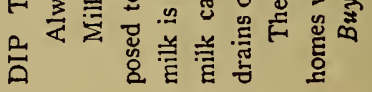
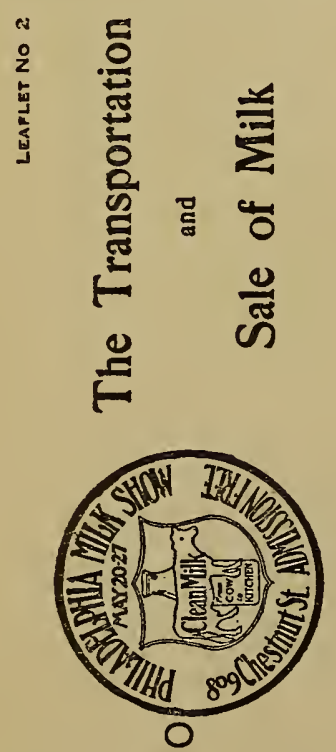

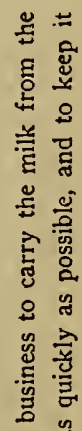

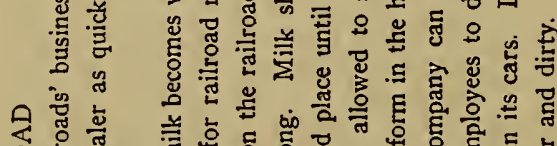

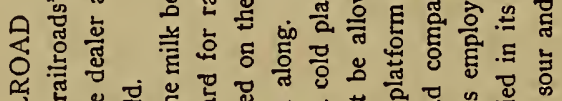

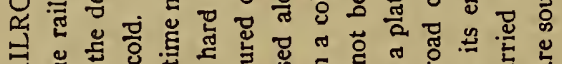

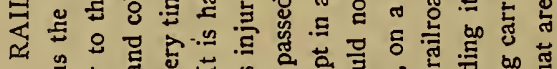

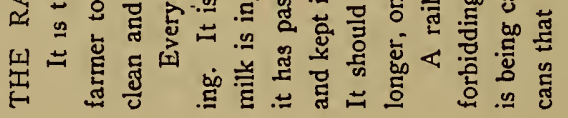

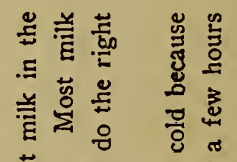

苟.

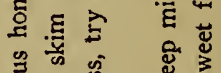

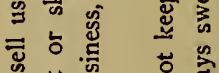

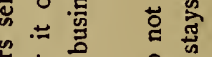

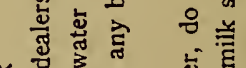

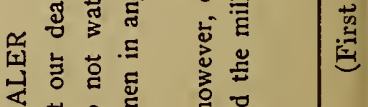

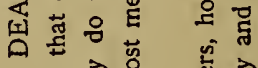

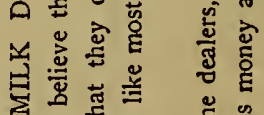

(1)

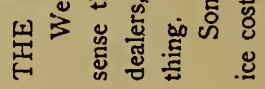

0 

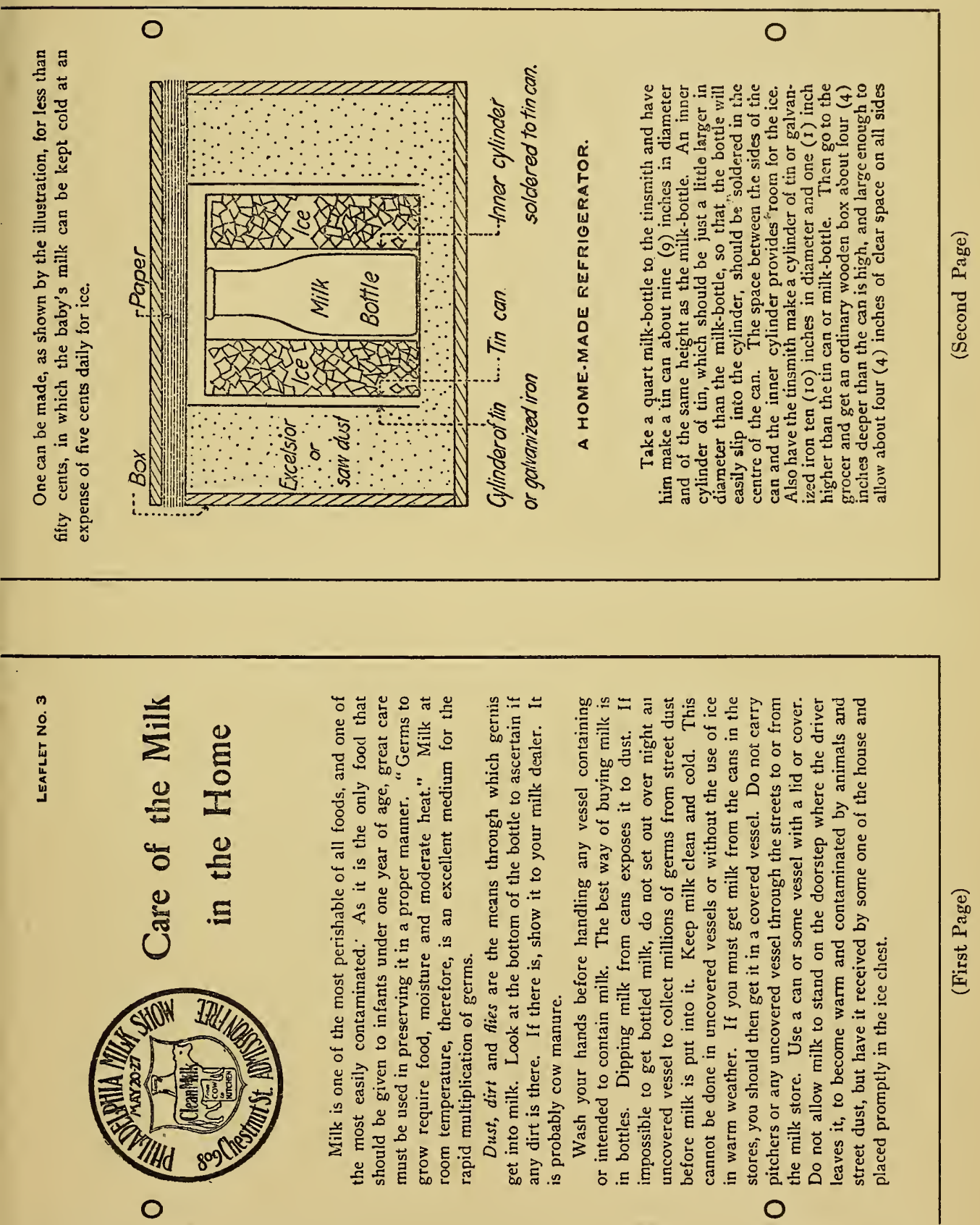

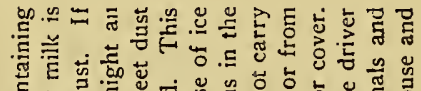

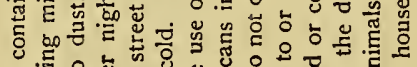

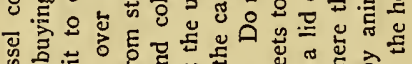

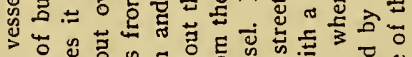

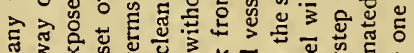

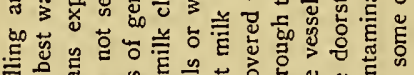

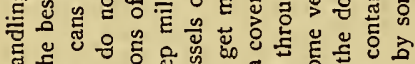
可 $E$ E

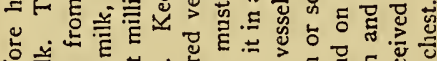

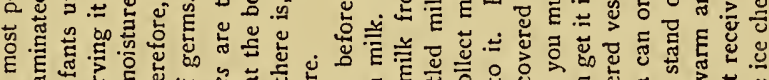

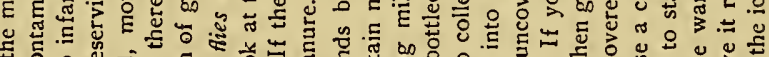

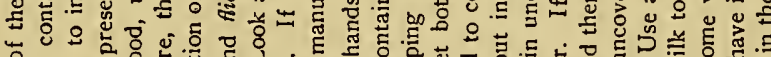
ডO

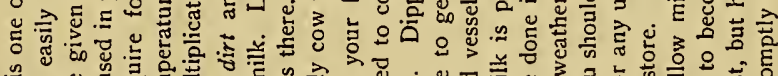

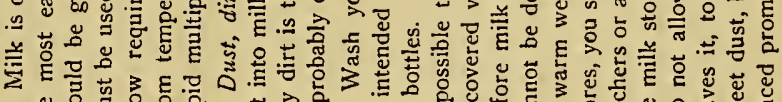

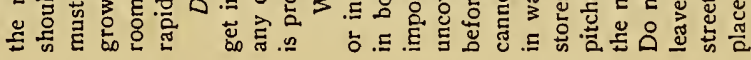




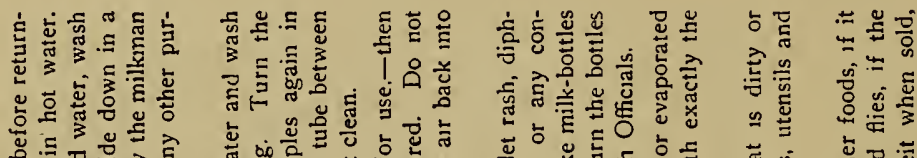

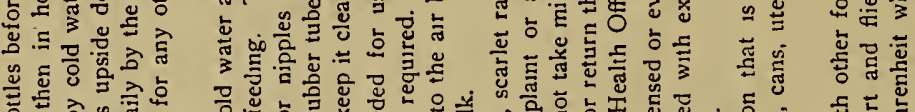

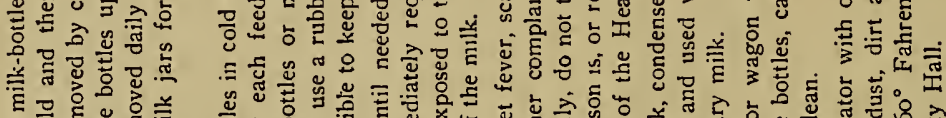

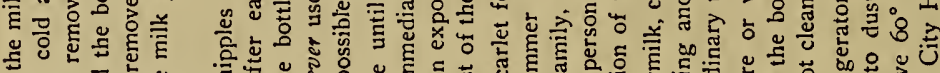

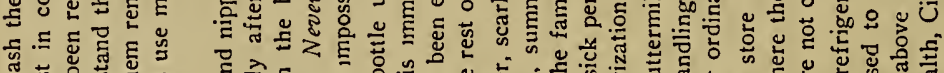

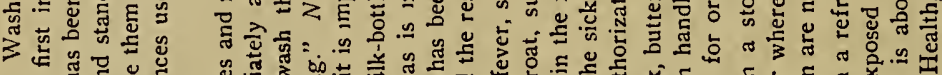

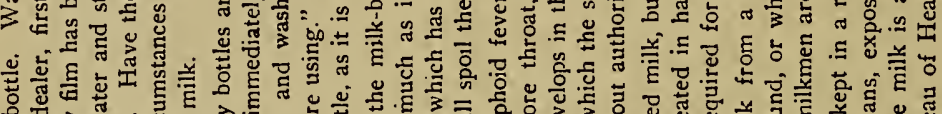

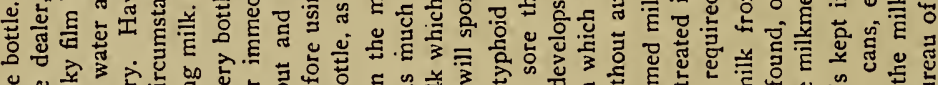

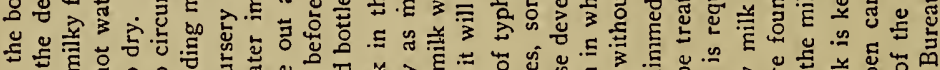

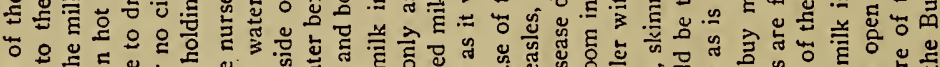

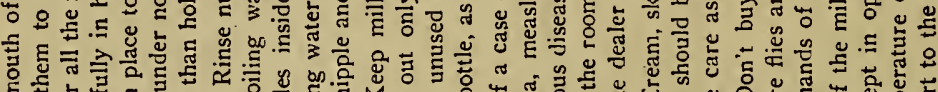

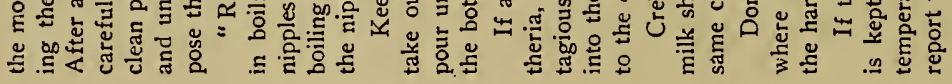

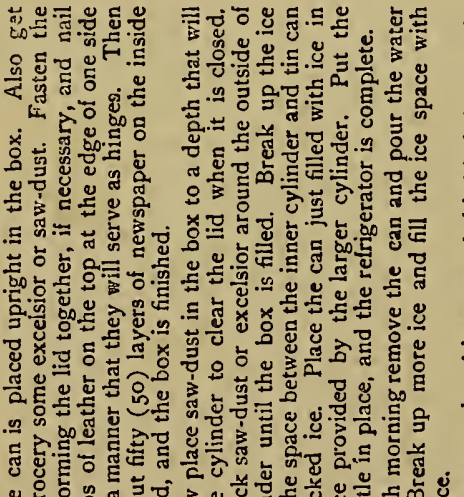
ن

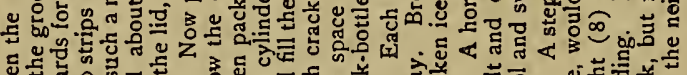

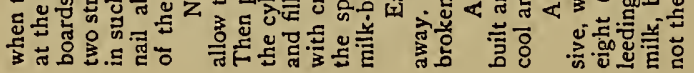

\section{O}




\section{O}

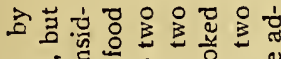

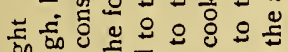

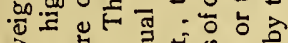

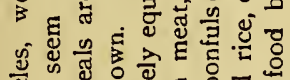

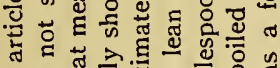

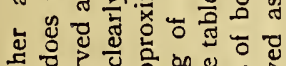

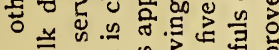

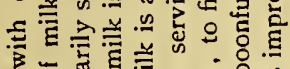

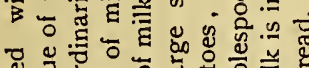

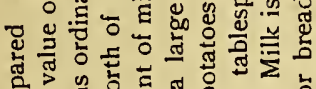

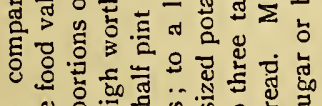

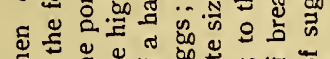

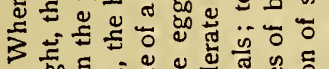

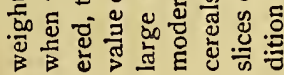

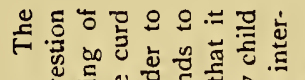

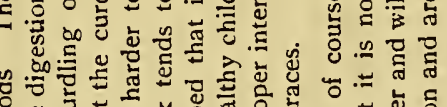

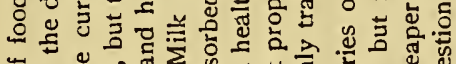

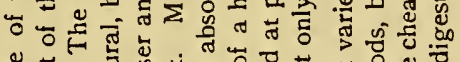

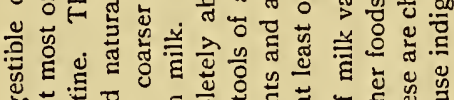

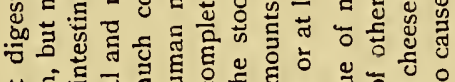

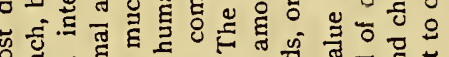

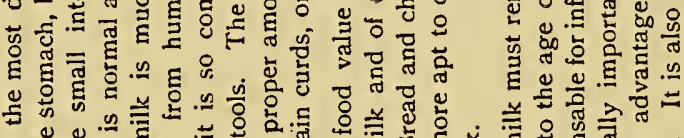

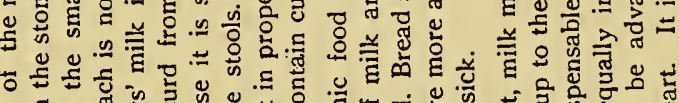

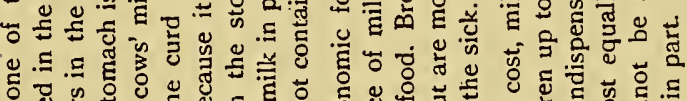
व च

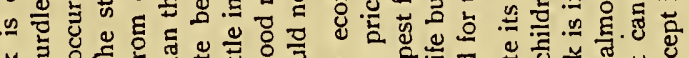

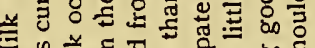

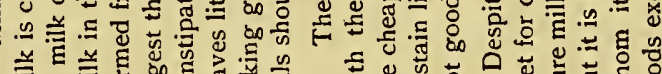

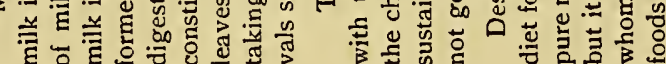

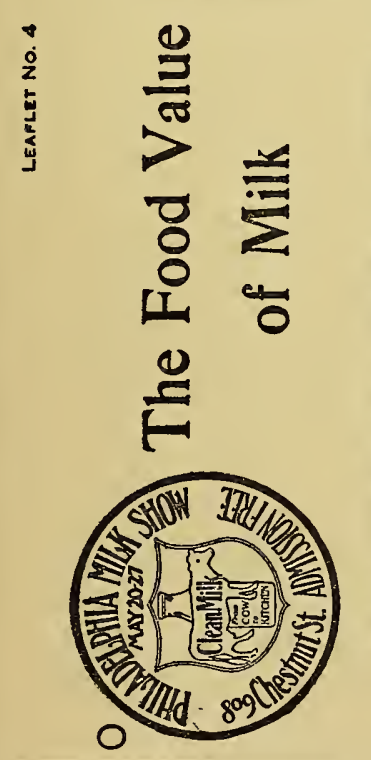

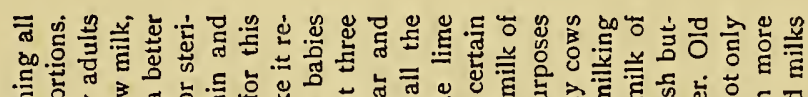

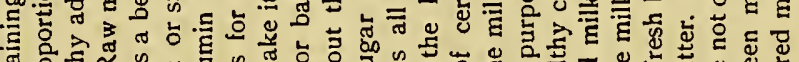

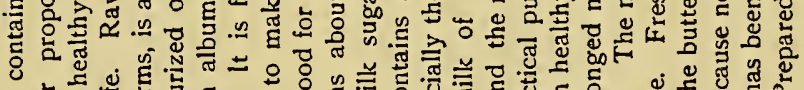

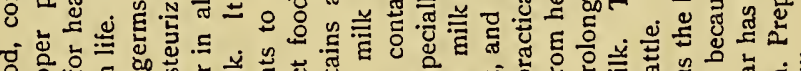

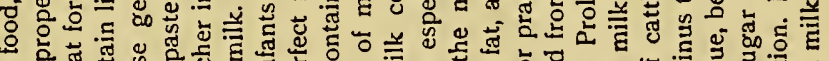

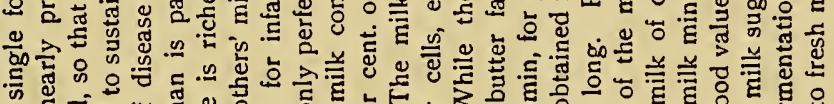

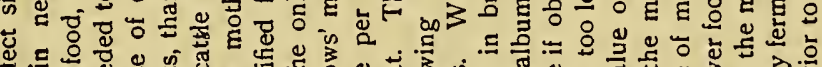

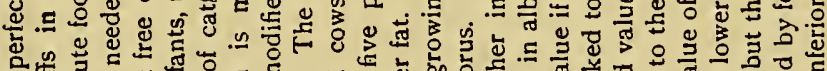

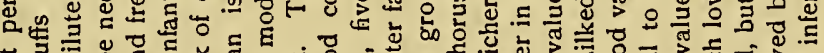

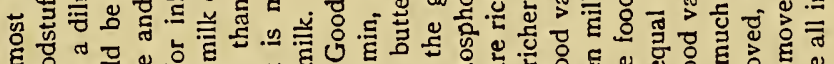
E

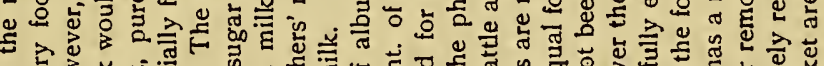

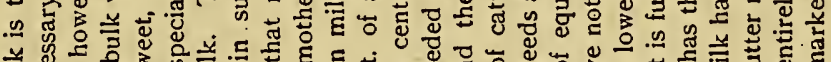

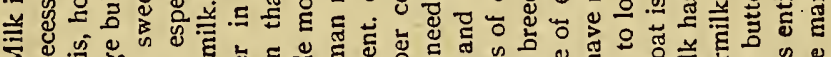

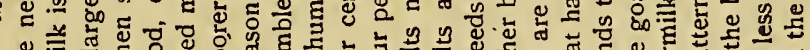

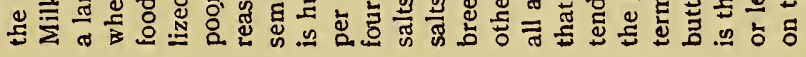


0

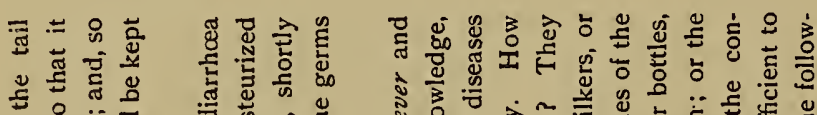

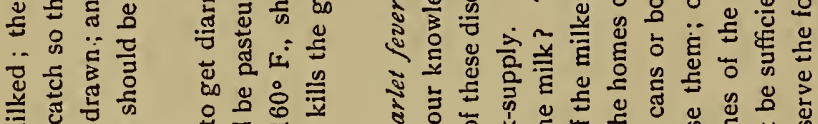

泉

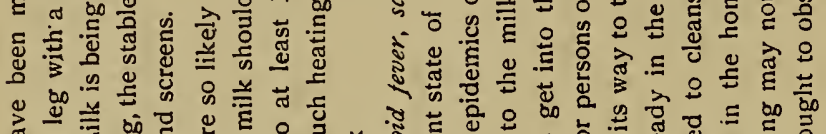

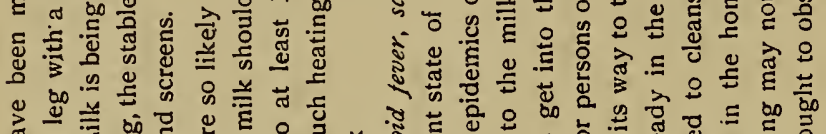

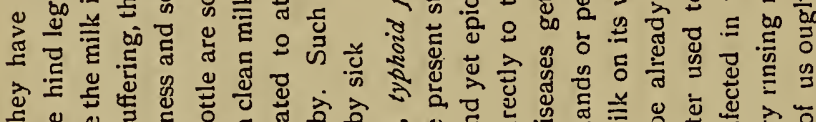

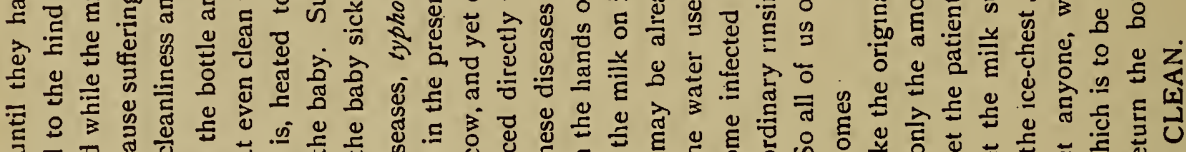

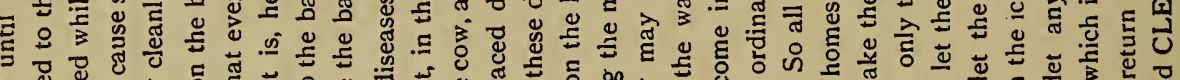

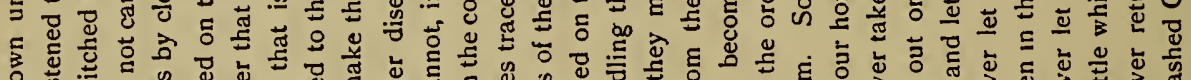

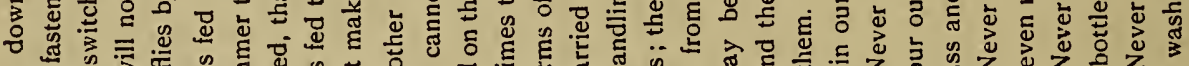

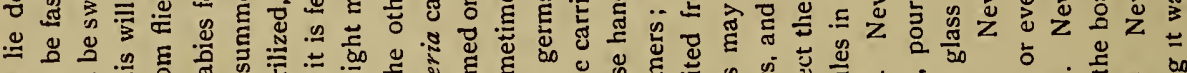

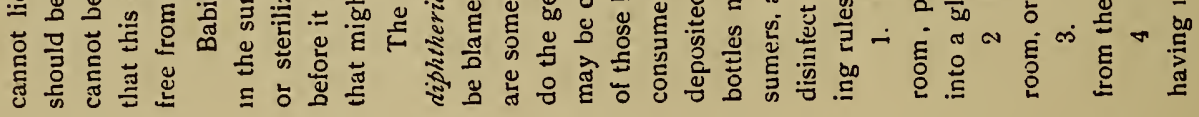

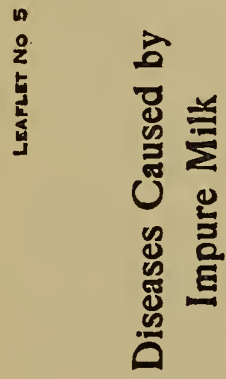

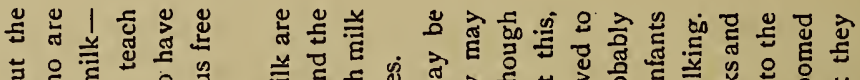

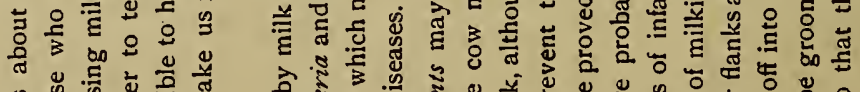

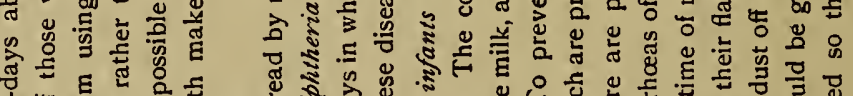

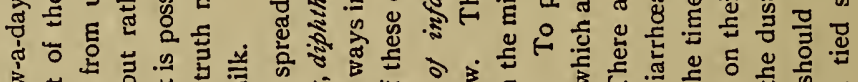

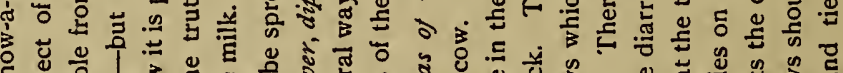

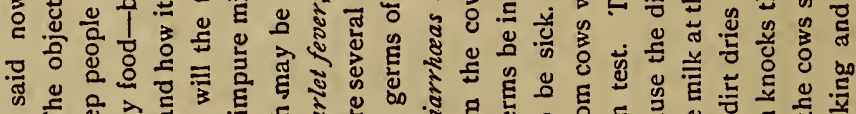

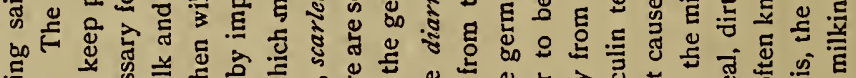

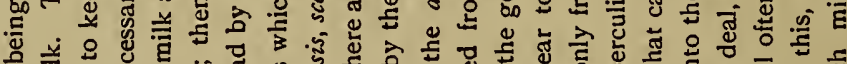

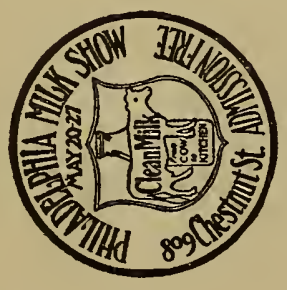

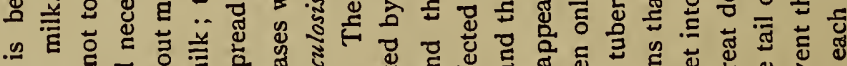

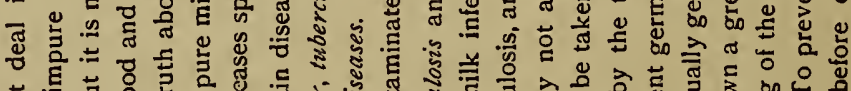

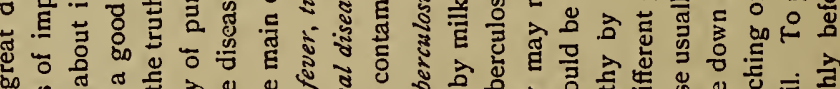

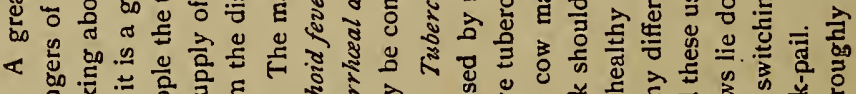
สี 


\section{0}

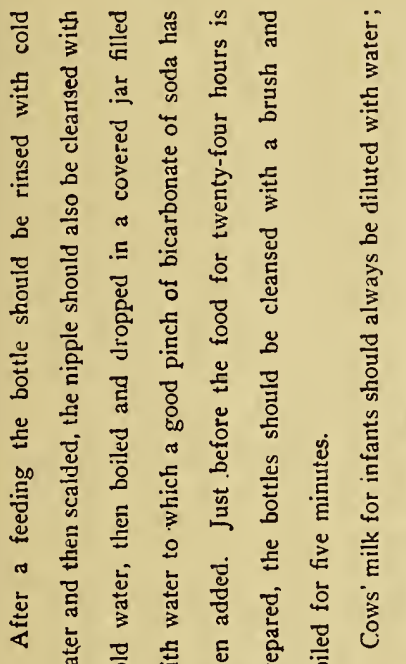

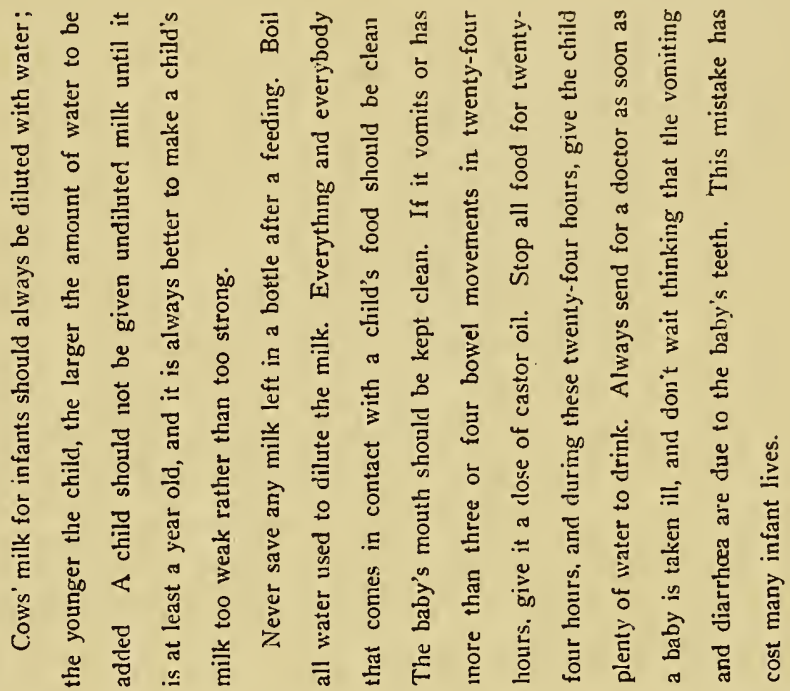

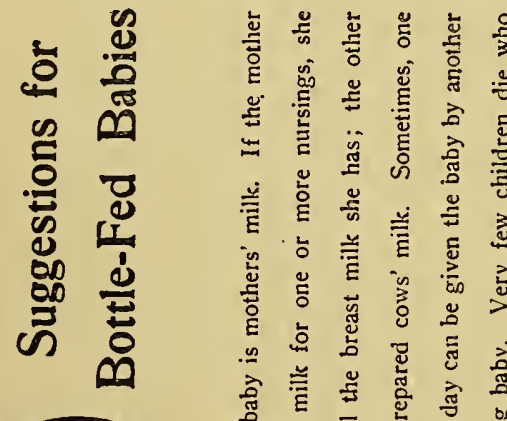

SI0" 70 (1)

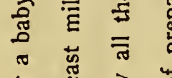

:

O

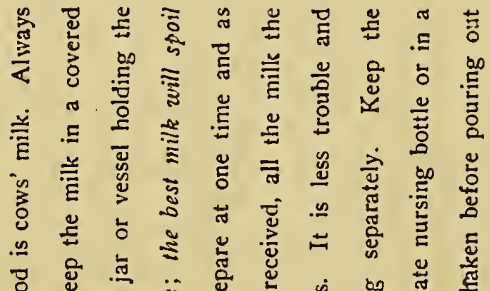

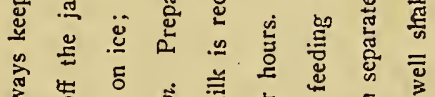

ก

i) 


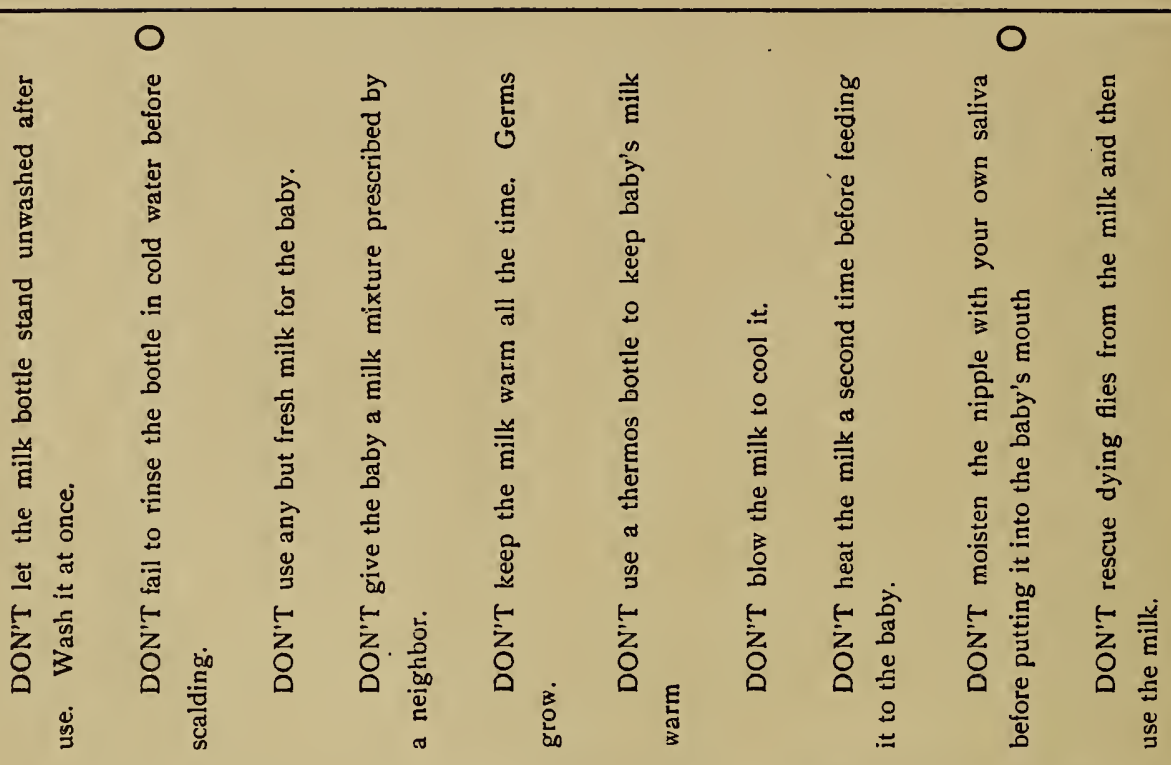

$\stackrel{s}{i}$

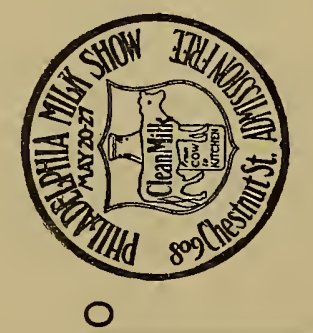

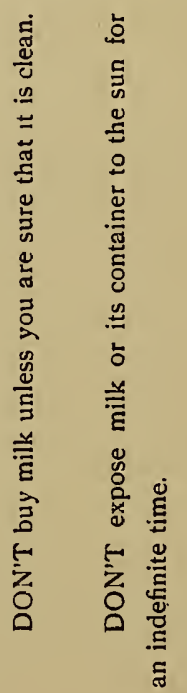

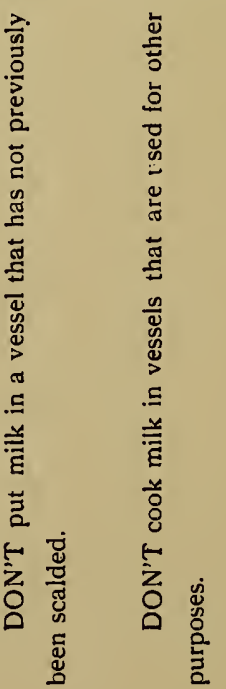

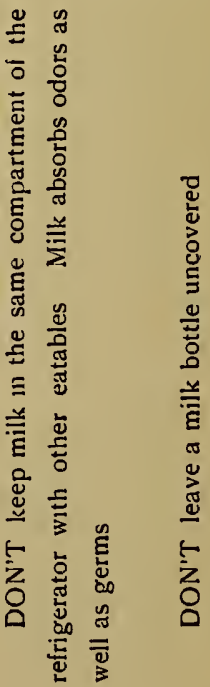



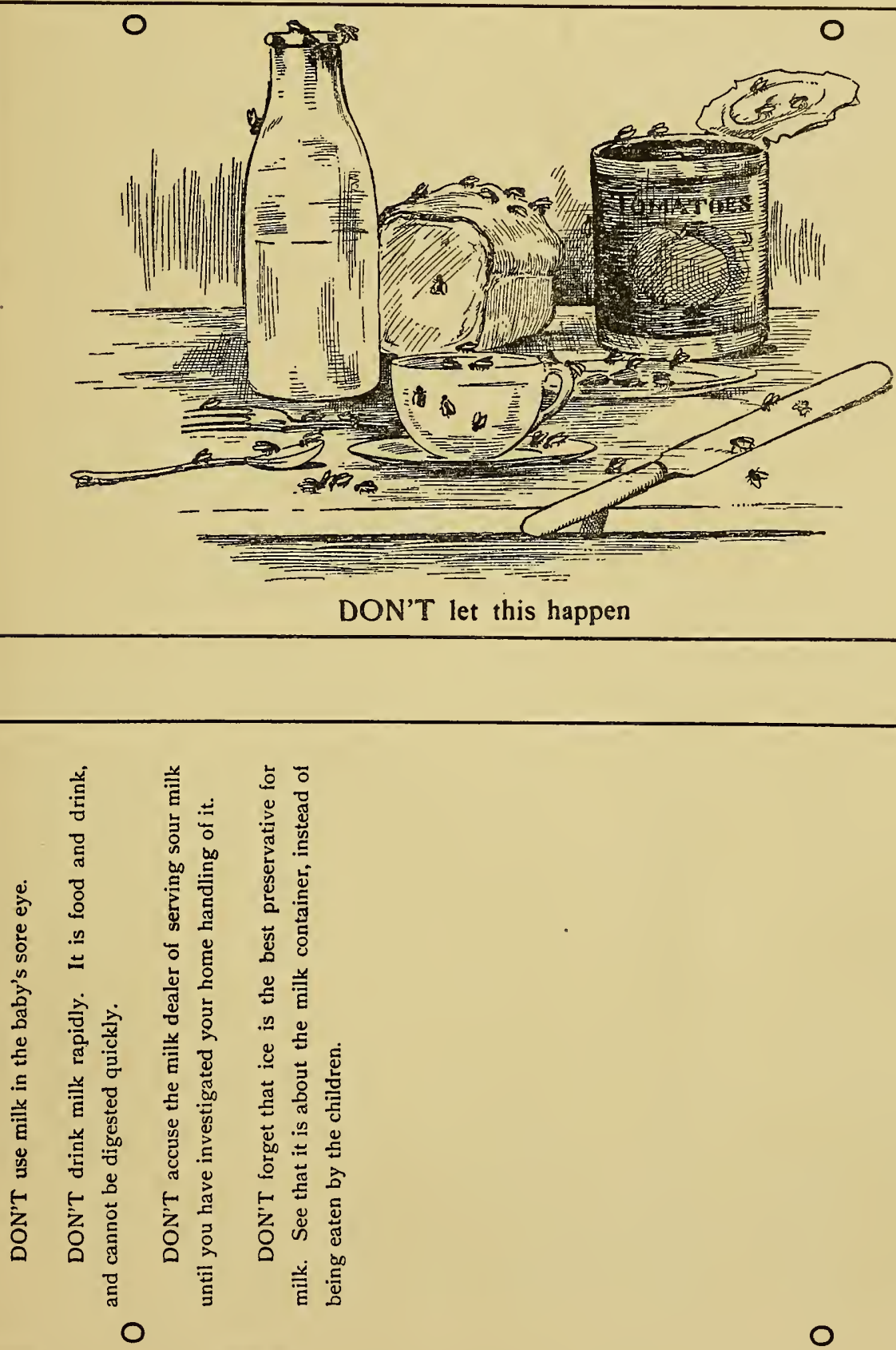


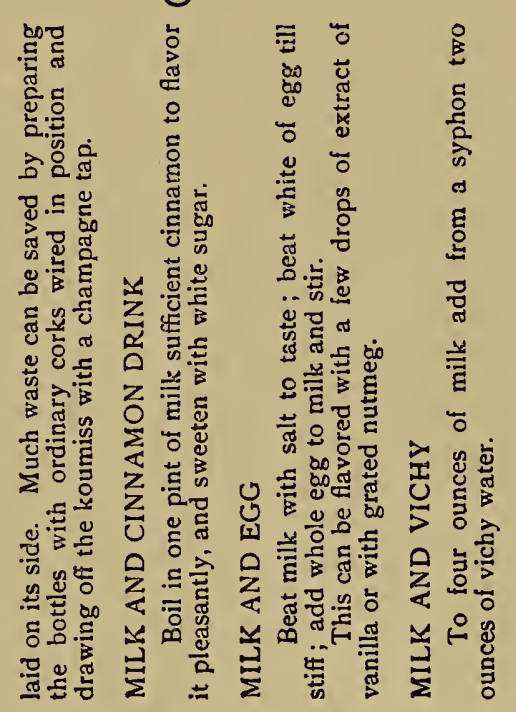

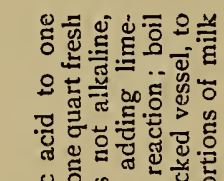

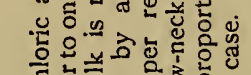

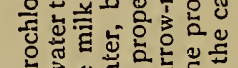

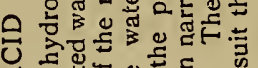

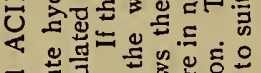

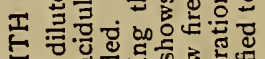

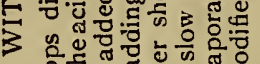

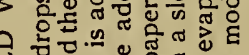

氠

至

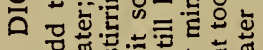

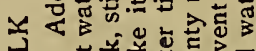

.

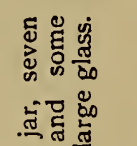

을

粍.

농

สั๊

के 吾

틍

(1) 韋佘

I

ज记造

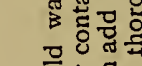

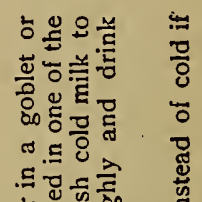

约

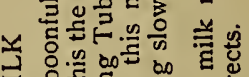

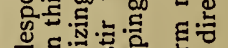

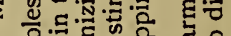

只元品

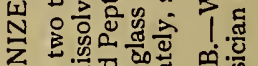

z

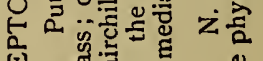

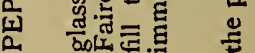

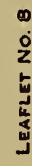

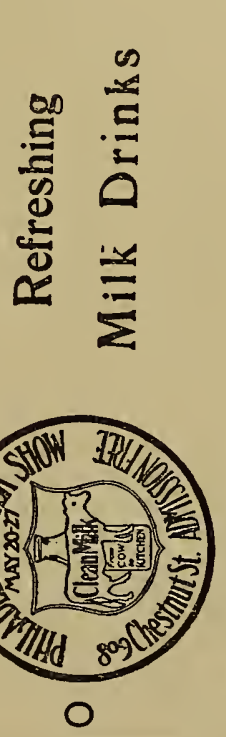

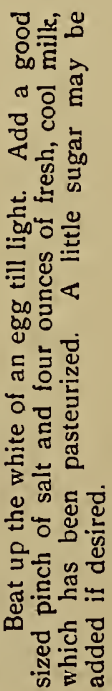

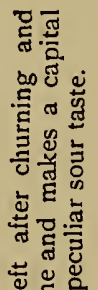

ธ등혈

귱ㅎㅀ

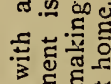

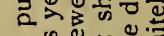

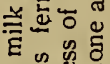

. 일

는들을혼

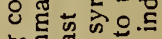

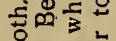

距

它宁导

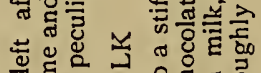

㣢品

造溇

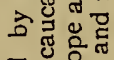

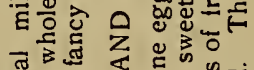

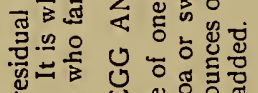

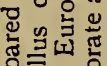

얼

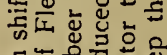

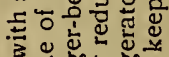

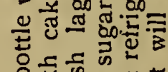

妾.

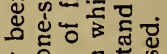

을율 툥

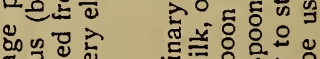

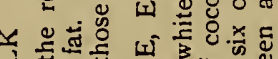

.

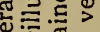

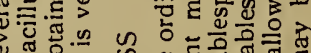

舟

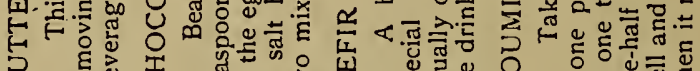

究

品

路气

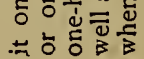

0 


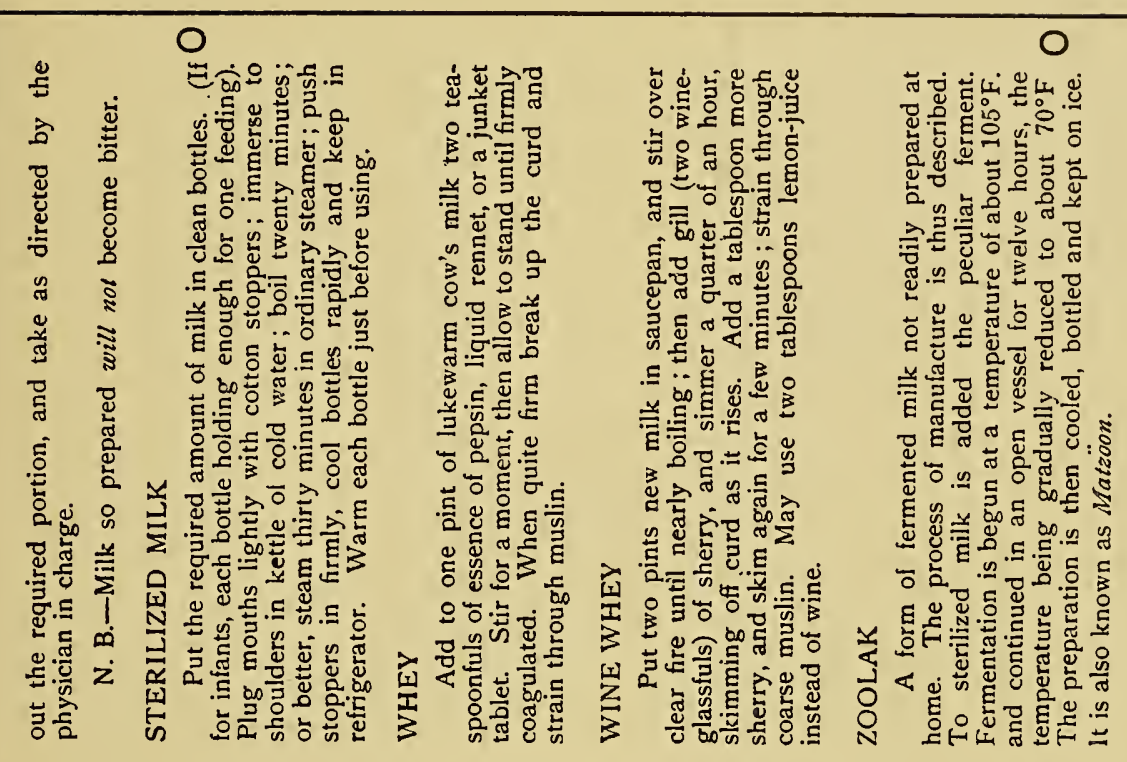

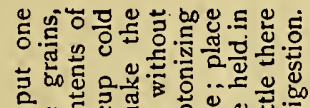

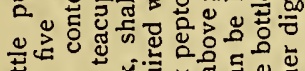

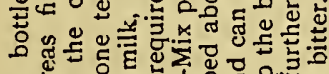

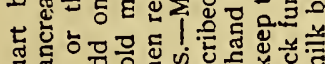

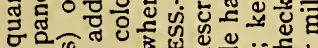

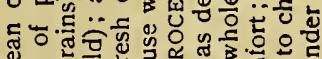
to ง.

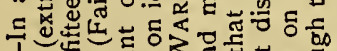

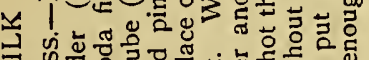

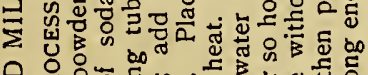

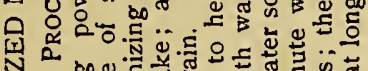

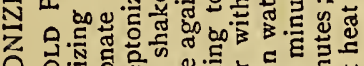

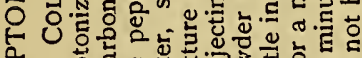

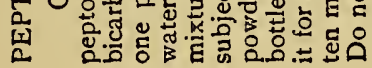

○

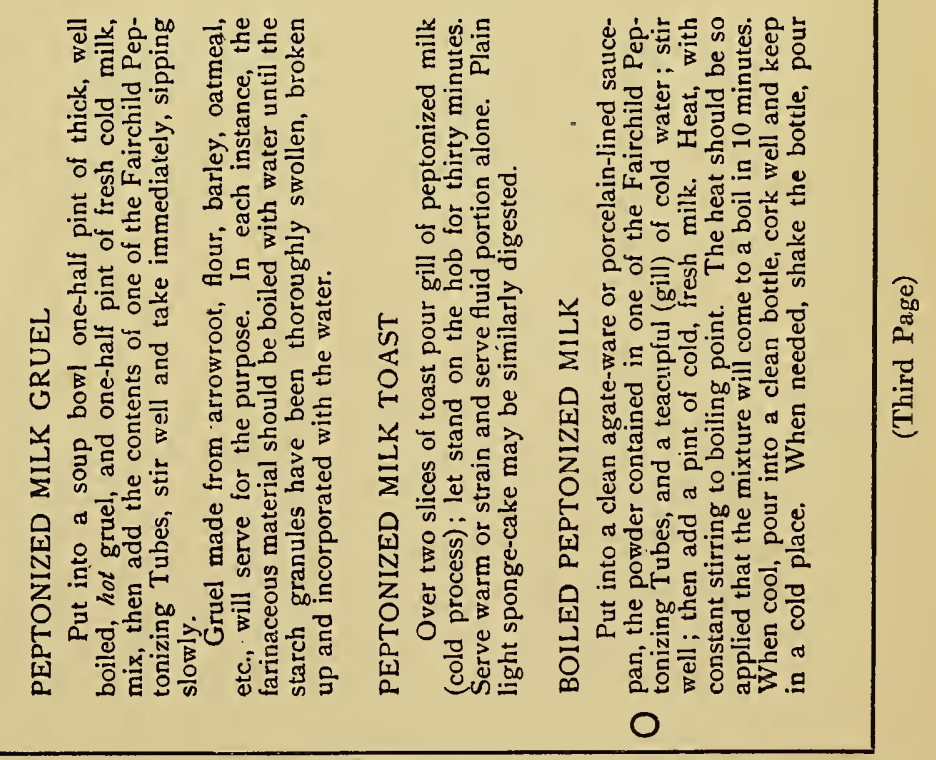




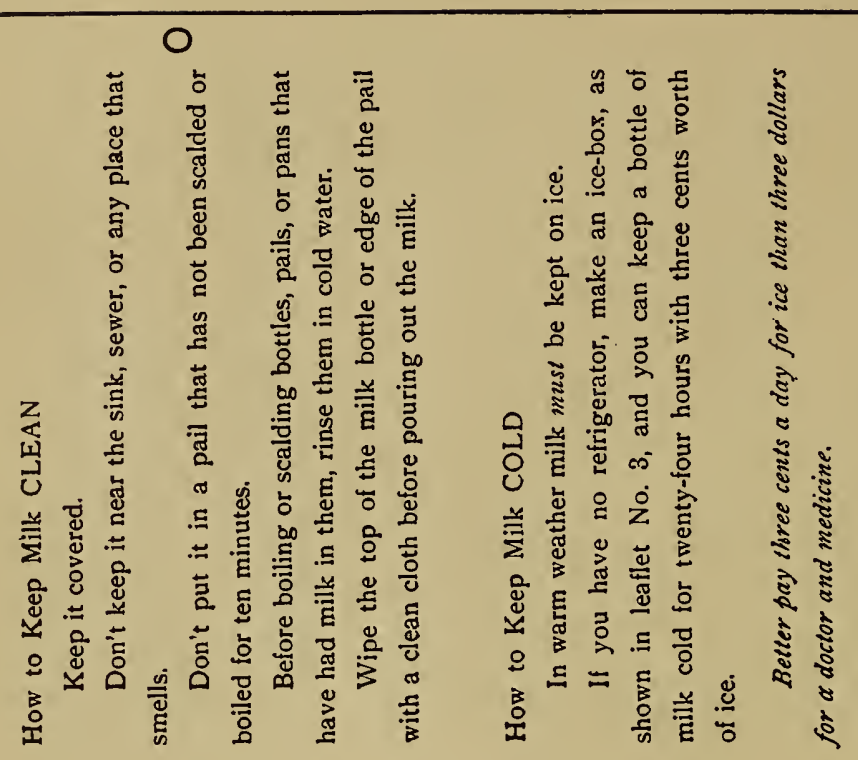

O

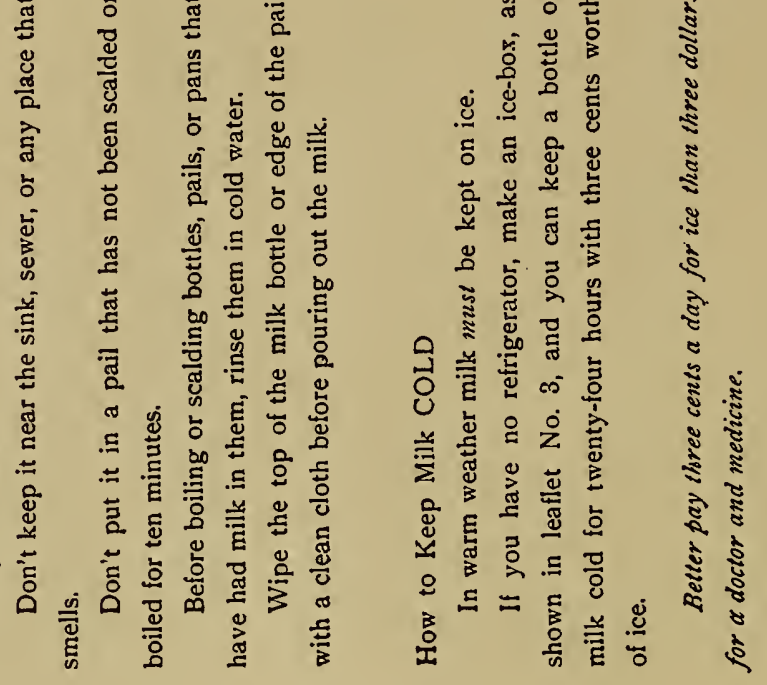

$\stackrel{\vdots}{i}$
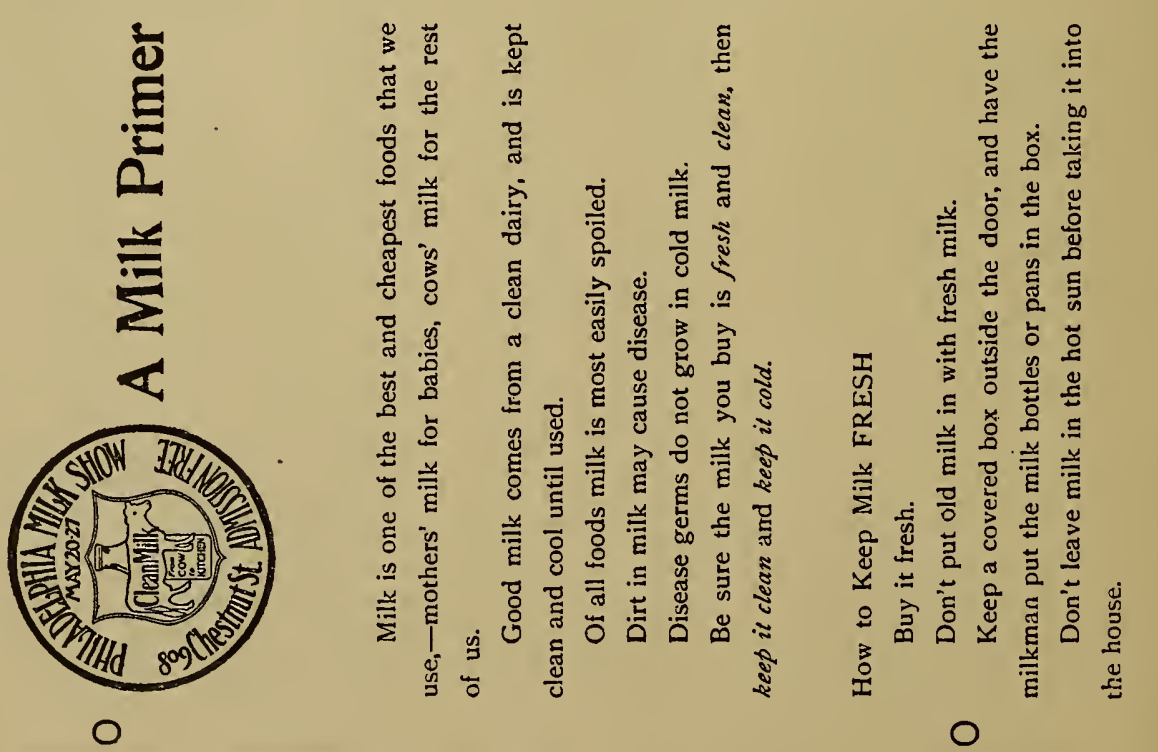


\section{What do You know about Milk?}

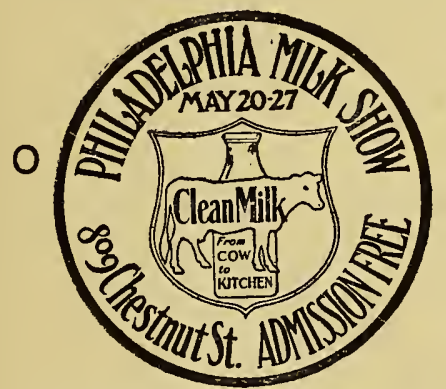

II You can get valuable information without cost in the following United States Government Documents.

Report of a special committee appointed by the Washington Chamber of Commerce to investigate the milk situation in the District of Columbia. 1911. Senate doc. 863.61 Cong. 3 Sess. 437 pages.

Milk in its relation to the public health. 1909. Bul. 56, Hygienic Lab., U. S. Pub. Health and Mar. Hosp. Serv. 834 pages.

The history, development and statistics of milk charities in the United States, 1910. Reprint from Pub. Health Reports 50, U. S. Pub. Health and Mar. Hos. Serv. 22 pages. The milk supply of two hundred cities and towns. 1903. Bul. 46, Bur. of Animal Industry, U. S. Dept. of Agric. 210 pages.

Sanitary milk production. Report of a conference appointed by the Commissioners of the District of Columbia. 1907.

Cir. 114, Bur. of Animal Industry, U. S. Dept. of Agric. 38 pages.

The unsuspected but dangerously tuberculous cow. 1907. Cir. 118, Bur. of Animal Industry, U. S. Dept. of Agric. 19 pages.

The score-card system of dairy inspection. 1909. Cir. 139, Bur. of Animal Industry, U. S. Dept. of Agric. 32 pages.

Some important factors in the production of sanitary milk. 1909. Cir. 142, Bur. of Animal Industry, U. S. Dept. of Agric. 22 pages.

Competitive exhibitions of milk and cream, with report of an exhibition held at Pittsburgh, $\mathrm{Pa}$., in coöperation with the Pittsburgh Chamber of Commerce. 1909. Cir. 151, Bur. of Animal Industry, 36 pages.

The dissemination of disease by dairy products and methods for prevention. 1910. Cir. 153, Bur. of Animal Industry, U. S. Dept. of Agric. 57 pages.

Milk transportation; freight rates to the largest fifteen cities in the United States. 1903. Bul. 25, Bur. of Statistics, U. S. Dept. of Agric. 60 pages.

The dairy herd; its formation and arrangement. 1904. Farmers' Bul. 55, U. S. Dept. of Agric. 29 pages.

Care of milk on the farm. 1906.

Farmers' Bul. 63, U. S. Dept. of Agric. 40 pages.

Breeds of dairy cattle. 1899. Farmers' Bul. 106, U. S. Dept. of Agric. 48 pages.

Bacteria in milk. 1909. Farmers' Bul. 348, U. S. Dept. of Agric. 24 pages. The use of milk as food. 1909. Farmers' Bul. 363, U. S. Dept. of Agric. 44 pages.

The care of milk and its use in the home. 1910.

Farmers' Bul. 413, U. S. Dept. of Agric. 20 pages.

Apply to your Congressman or to the Bureau or Department Concerned CITIZENS' BUSINESS, No. 17 Bureau of Municipal Research of Philadelphia REAL ESTATE TRUST BUILDING 


\section{APPENDIX E}

Application Blank and Contract for Commercial Exhibits. Size: $81 / 2$ Inches by 11 Inches.

\section{eriture}

Honorary Chatrman, How. JuHn E. ReveuRn

Chaimon, DR. JOSEPH S. NeFt

Vhes-Chaimeno, Dr. Charles J. Hatfielo

Secrelong. De. Joseph WaLSH

Execullioe Secrelary. Mr. Arthuz E. Post

Frarurting Extribit

Dr. marke Lave

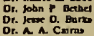

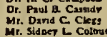

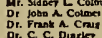

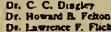

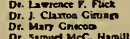

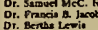

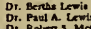

Office, Room 588, Cily Hall

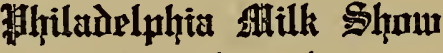

May 20th to 27th

UNDER the AUspices or

Department of Public Healh and Charitles

grtilk Commission of the Philadelphia Pediatric Society

Veterinary Department of the Uniberstly of Pernsylocnia

Bureau of Municipal Research of Philadelphia

And XTam Othe Cospenoting Apeneder

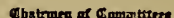

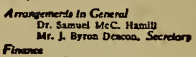

Dr. Richen 4 . How

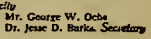

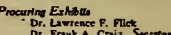

Dr. Frout A. Craiz Serreten

Dr. S. T. Rerro

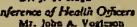

Edecoltion

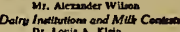

Dr. Locis a Kich

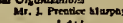

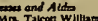

Phïadelphia

\section{APPLICATION FOR SPACE FOR COMMERCIAL EXHIBIT}

1911

DR. JOSEPH WALSH.

Chairman Commintee os Commercial Exhibits

of the Philadelohia Mill Show.

732 Pine Stroet, Philadelphia, $\mathrm{Pa}$

You are hereby authonized to reserve for our use the following space in the Exhibit, Hall of the Philadelphia Milk Show:

agrce to pay $50 \%$ of the charge for space immodiate'y on acknowledgment of reservation and the remsining $50 \%$ on May $19 \mathrm{th}$.

nn..............................agree to abide by all regtirenents and restrictions mentioned on the reverse side of this sheet.

Printed on letter head of committee on procuring exhibits

(Front) 


\section{REGULATIONS REGARDING COMMERCIAL EXHIBITS}

The Philadelphia Milk Show will be held at 809 Chestnut Street, from Saturday moming, May 20th, to Saturday evening, May 27th.

The Hall will be open for the installation of exhibits for several days before the public opening. All exhibits must be in place by Friday, May 19th.

The charge for space will be $\$ .50$ per square foot. Exhibitors must pay $50 \%$ of the charges far space immediately on acknowledgment of reservation and the remaining $50 \%$ on May 19th, 1911.

Exhibitors are expected to attend to the installation of their own exhibits, and a certain amount of uniformity will be required.

No subletting of space will be permitted.

No refund will be made for space ordered and once accepted.

The Philadelphia Milk Show will not be responsible to exhibitors against loss of any kind.

Exhibitors must agree to make no unwarranted claims and be guided in this regard by the opinion of the Censor Committee of the Milk Show.

All exhibits are subject to censorship and may be ordered withdrawn at any time if found objectionable. In the event bf an exhibit being ordered withdrawn, a refund of rental corresponding to the remaining days of the exhibit will be made.

The transfer of articles in sale during the course of the exhibit is prohibited.

A description of the exhibit should accompany the application for space.

(Reverse) 


\section{APPENDIX F}

Entry Blank for Milk and Cream Contests. Size: 8 Inches by 101/2 Inches

Class 6, market milk Class 7, market cream Class 8, certified milk Class 9, certified cream
(The entry blank for each class was the same with the exception of the class heading in the middle of the front side)

\section{Philadelphia Milk Show}

\section{MILK AND CREAM CONTEST PHILADELPHIA, PA.}

MAY 20-27. 1911

UNDER THE DIRECTION OF THE

Dairy Division, Bureau of Animal Industry,

U. S. Department of Agriculture

Only this Official Entry Blank will be Accepted

CLASS 6, MARKET MILK

Gentlemen:

Please enter for me four quarts of market milk in competition for prizes offered by the Philadelphin Milk Show, in accordance with the conditions herein prescribed.

Post Office Address.

Date.

(1) Competition in milk and cream department is open to all milk and cream producers in the United States and Carade

(2) Producers of Market Milk may compze in both Market Milk and Market Cream classes.

(3) Producers of Certified Milk may compete in both Certified Milk and Certified Cream classes.

(4) Producers of milk can make but ene eniry in any one class.

(5) Producers of Cerified Milk or Certified Cream are barred from competicion in Market Milk and Martet Cream classea. All samples of certified milk and cream must be accompanied by a certificate iseued by a Medical Milk Commission.

(6) Entries in milk classes eonsist o? 4 quarts of milk in quart bottles.

(7) Entries in cream elasses consibt of 4 pints of cream in pint bottles.

(8) All entries of milk and cream after scoring become the property of the United States Department of Agriculture.

(9) No exhibitor will be entitled to a medal or diploma who does not make anewer to each question, sign declaration, and forward this official entry blank to G. M. Whitaker, Superintendent of Milk and Cream Exhibits, care of Veterinary School, Univervity of Pennsylvania, Philade!phia, $\mathrm{Pa}$. 


\section{HOW TO COMPET:}

Milk entered to compete for prizes, must be sent by express or otherwise, from station nearest the producer, direct to G. M. Whitaker, Superintendent, Milk and Cream Exhibit, Care of G. H. McKay, Reading Terminal Market and Cold Storage, 1118 Arch Street, Philadelphia, Pa.

Express charges on exktoits must be prepafd to cestination. Bottes must be carefully packed, caps should be sealed, making bottle air tight, and both the top of botte and cap should be protected with

sportation. The package should be plainly addressed on outside. A card

In order that all milk entered by exhibitors may be of the eame age when scored, it is hereby apecified that it shall be produced Monday, May 15th, and shipped and delivered to express company at once. This is necessary for perfectly fair competition. A representative of the Department of Agriculture will be in Philadelphia to take charge of the milt on its arrival and see that it is properly cared for.

\section{QUESTIONS TO BE ANSWERED IN DETAR BY EXHIBITORS OF MHL}

1. On what day and hour was the sample of milk, entered in this show, dmwn?

2. How many cows contributed to the sample of milk entered?

3. How many cows in your heid are now giving milk?

4. How long since the cows contributing to the sample of milk treshened? (Average time)

5. Are the cows supplying this sample, grade or pure bred?

If pure bred, give name of breed

6. What kind and amount of feed was given cows daily during the week preceding the prosluction of this eample of milk?

7. Were cows cleaned previous to milking?

If so, describe method of cleaning

8. Were cows in stable or out of doors when the sample of milk was dmiw?

If in stable, how was stable cared for?

9. What precautions were taken by milkers as regards cleanliness of clothing and hands?

10. How many milkers were engaged in milking the sample entered?

11. What kind of pails were used, narrow or wide top?

12. How were pails cleaned previous to use?

13. Was milk drawn from the cow direct into pail or shrough cloth cover or cotton filter?.

14. What method of straining milk, if any, was followed?

15. How long after milk was drawn from cows before it was cooled?

16. Describe milk cooler, if any was used.

17. How was milk cooler prepared for use ?

18. To what temperature was milk cooled?

19. How were bottles and caps prepared for use ?

20. What bottling process was used or what method of bottling was followed?

21 How was milk cared for after boteling and previous to shipment?

22. Give date and hour when milk was (or will be) shipped..

23. Do you wish shipping cases and bottles returned at your expense?

24. Have you previously exhibited milk or cream at any local, state or national show?

Remarks.

do bes by declare each and every statement in answer wo the abovo I,........................ free from preservatives, and that it has not been heated or changed in any ray. 


\section{APPENDIX G}

\section{Reprints of a Few Press Comments}

From The Outlook, New York City, July 29:

\section{THE SPECTATOR}

Gay with red, white and blue bunting, with a big electric sign above the entrance, the Milk Show opened its hospitable doors free to all comers. And how they came! Entrances in the front of the store building on one street, exits at the back to the street behind, and big uniformed Philadelphia policemen passing the crowd through, and yet it remained always a dense crowd-orderly, eager and intensely in earnest to see and understand. "To enlighten, not to frighten," was the motto over the front entrance, and the enlightenment was everywhere, from the bacilli cultures in the show windows to the model dairy barns and the certified milk exhibited inside. Those bacilli cultures had a crowd three feet deep all the while around the window, yet they were very simple - just two jars with a little milk in each one. In one jar a single fly sported in the milk; in the other a dozen were enjoying themselves bathing and drinking, while a big placard read:

\section{If it takes I fly 3 hours to contaminate the sterilized milk in Jar A and 12 flies 5 minutes to contaminate the sterilized milk in Jar B How long will it take you to kill all the flies in YOUR HOME? \\ Daily at 3 P. M. the results of the con- tamination will be demonstrated.}

There was demonstration enough inside-colored charts of the fifty-seven varieties of bacilli, enlarged and colored until one was reminded of the small school-boy who, when he saw one of 'Turner's sunsets, remarked seriously, "That looks like the inside of a drunkard's stomach!" Ovens for baking milk and killing all bacteria and every kind and sort of sterilizing process were displayed on all sides. A series of round glass affairs for cultivating germs in scientific style were ranged on shelves, where the public could see just how they grew, and this held a double row of gazers all the while, the white spots of colonies under the glass speaking for themselves. One chart showed a milk-can with radiating lines to the different streets of a small town, and the legend: "Hightown-2,000 population. Diphtheria, 28 cases and 11 deaths-traced to boy who washed milk-can." On the other side of the same aisle, in mute, delightful testimony of contrasted safety, rose rows of shining glass bottles full of pure, creamy milk, set among green ferns and foliage, and served by smiling, spotless houris in white aprons, who did a rushing trade every minute. "Look first upon this picture, and then on that" did not fail in its agelong educational effect, even on the children.

There were [hundreds of] children there, by the way. They came from that part of the city where the milk usually is at its worst. The public schools sent them, the street car company transported them free of charge, and twenty-five hundred each day were shepherded through the Show. Their little feet came trotting and shuffling along, and that day's contingent seemed to be about ten years old, on the average, with descents occasionally as low as five. Americans, Irish, Germans, Jews, Poles, Italians, Slavs, Negroes--they succeeded one another like waves of the cosmopolitan future. They were halted in squads before this exhibit and that, and stared impartially, round-eyed, at the bacilli, the modified milk machinery, and the silver trophy cups which, nine in number, showed that clean milk is a sporting proposition nowadays. What they really liked best, though, were the four models of dairy barns, com- 
plete down to the last detail, cows, horses, and all, with the farmer standing in his barnyard like Noah with the ark. "Excellent," "Good," "Fair," "Bad," the four models were labeled, and the "Excellent" one was truly a pleasant sight, with its two rows of fat doll cattle standing on the wide, unpartitioned, clean floor, lighted by big windows, and spotlessly kept. "Good" showed horses kept in the same barn, and some carelessness in keeping things in order. "Fair" was in worse disorder still, and not so well lighted or arranged. As for "Bad," with its higgledy-piggledy horses, cows, and sheep, its piled trash in every corner, its many partitions, its lack of light, its realistically dirty barnyard and grimy farmer, it was an object lesson indeed. "It's the usual kind, though," commented a dairyman behind the Spectator. "Get out into the country, and you'll find it everywhere. There are more farmers every year building new barns right, of course-but the old barns!" Evidently the Milk Show had thought of this side of it, too, for a lecture in connection with it was announced, the Spectator saw, for the next day, on "Improving Old Barns."

Many practical problems were illuminated at the Milk Show. For example, the question "How far should the milk in a bottle reach?" was illustrated by pictures, showing that unless the milk came up as far as the stopple, leaving no visible space below the cap, it was short weight, so to speak. "What do you know about the ice-cream sold by street venders?" was another awakening query. "We can tell you"- and then followed statistics and pictures calculated to ruin the careless ice-cream street trade. Bacteriological specimens of ice-cream from the State Laboratory backed up the placard. The Spectator has always heard of the fame of Philadelphia ice-cream, but the street venders of the city evidently use another kind. The glass milk bottle, too, came in for its share of criticism. It used to be progressive - of course it is still a vast improvement on the dip-tank, against which Massachusetts women have lately declared war-but now the march of milk improvement has distanced it. The glass bottle is expensive, therefore must be returned and used again. This makes its cleanliness problematical. At the Milk Show the paraffined paper bottle or container, used once only by the milkman, was displayed in several forms. It is ideally sanitary, and has now been improved past several objections. "You can see through it now," explained one dealer to another, discussing its merits. "It used to be opaque, and the customers always said the bottle wasn't full. Now you can show 'em how high the milk comes. The only thing I'm not sure about is, will the fluting inside the neck catch the cream and waste some of it? It has to be fluted to allow for the expansion, so that it won't burst, like a glass bottle, if the milk freezes. It's a good proposition-we're going to put it in." From such experts as these the Spectator heard the opinion that it was "a first-rate Show"; so they, as well as the children, were a satisfied audience.

Also it was Woman's Day. The Civic Club had sent out invitations to all the women's clubs of eastern Pennsylvania, New Jersey, Delaware and Maryland, and the members came, shoals of them, to look at the Show and listen to two special lectures by women. One was on the house-fly, the other on the babies of the tenement and the way to give them clean milk. The Spectator is almost sorry for the house-fly. It always was doomed when it got into the home of an old-fashioned good housekeeper. But she only killed it on the premises. To-day the housekeeper is leaving home, with her loins girded, to track down the fly before it reaches her gates. She is treating the fly by community methods, and she now calls it "the typhoid fly," which settles it. "House-fly" was an amiable, intimate name, which left it optional whether to kill or spare. But "Shoo fly!" has now changed to "Kill that fly!" and even the most careless housekeeper feels the difference. The lecturer of the day had numberless lantern slides illustrating the best methods of fly capture. One simple wire trap was shown, placed over a garbage-can near an ice-cream parlor. In fifteen minutes this trap had broken the record with twentyfive hundred flies captured. In Worcester, Massachusetts, the boys had placed these fly-traps on tomato-cans in which a little refuse was put as a bait, and had caught flies ad infinitum. For these flies they were paid so much a hundred, and there were so many thousands of insects captured that they were used as fertilizer! A special stamp bearing the household words "Kill That Fly" had been invented by the lecturer, and is now being extensively used by the women's clubs and charitable societies on their mail this summer.

The Russell Sage Foundation placard was a great favorite. It was a series on the plan of the Industrious and the Idle Apprentice. Five cartoons showed the causes and effect of dirty milk-the dirty cow in the cow-shed, the dirty can and transportation, the dirty dip-tank at the grocer's, the dirty kitchen in the tenement, and the dying baby in its distracted mother's arms. Five others showed alluringly the Clean Milk idea-the clean cow and dairyman, the clean glass bottle and shipment, the clean milk station, the clean ice-pail in the tenement, and the healthy child, cooing and comfortable, being weighed by the smiling mother. Another great success was a chart asserting that "Milk is the only safe food for infants - these are dangerous!" and showing, finely drawn and colored, an assemblage of pictures, one after another, of an ear of corn, a cucumber pickle, a cone of ice-cream, a pretzel, an apple, a banana, a bottle of soda water, a large, lucious slice of watermelon, and a cup of coffee or tea. 
Near this was a photograph of a group of school girls learning how to take care of babies, and another of a class of mothers learning how to prepare milk. A young German couple stood entranced before these photographs, arm in arm. They had left the baby at home, but they were talking about it. "They are from the Settlement," some one explained. "Crowds of people from the slums are coming every day, so as to learn how to keep the babies alive through the hot summer." The number of poorly dressed women who were crowded three deep around a nurse who was explaining how to keep milk in a homemade ice-box with the least quantity of ice impressed this information still more deeply on the Spectator. Here was the ultimate consumer-the very small consumer, and yet the very important one, too.

It was for this reason, and for many others, a very hopeful Show. It was a get-together Show for the dairyman, the middle-man, the buyer of milk, on the one hopeful plane of "Clean Milk." The Massachusetts slogan, "We don't want dirty milk," might have been used by the lecturers, exhibitors, audience, and all. Like the fly, dirty milk is doomed. The twenty-first century will know it no more than it will the yellow-fever mosquito. Instead will come the millennium which the Mother Goose of the Milk Show pictures so alluringly:

These are the cows with the coats like silk

Who give the clean and wholesome milk;

These are the stables sweet and clean,

The finest stables ever seen,

Where dwell those cows, etc.

These are the milkers in suits of white

Who milk the cows each morn and night

That dwell in the stables, etc.

This is the dairy, all complete

With apparatus clean and neat,

Where the milk is cooled below forty degrees

And bottled straightway in jars like these,

Then sealed air-tight with paraffin

(No dirt and germs can enter in),

Then packed in boxes with lots of ice,

And shipped to the city, this milk so nice,

From the pails of the milkers in suits of white

Who milk the cows each morn and night

That dwell in the stables sweet and clean,

The finest stables ever seen

Where live the cows with coats of silk

Who give the clean and wholesome milk.

No wonder the Milk Show was draped in red, white and blue. No wonder that [over seventeen] thousand people crowded to see it that day, listened to its lectures, and sat applauding in its movingpicture shows. When a city forgets politics and gets down to a real community question like pure milk, it is a thing to be noted. The Milk Millennium is on its way, marching in the trotting feet of the schoolchildren-and therefore sure to arrive!

Editorial in the Philadelphia North American, May 21:

\section{A CHILD-WELFARE EXHIBIT}

John Dewey, pyschologist, says: "The indefinite improvement of humanity and the cause of the little child are inseparably bound together."

Few of the good men and women who are giving freely of their time and talents and money would be able to define their interest as anything but an expression of humane tendencies. And yet it is something more, this almost universal concern for children. It is the turning of the face of the race to the future.

Up to the present civilized races have been to some degree ancestor worshipers. Where this was manifested in the most extreme form, as in the case of the Chinese, it stopped all progress, and the race stood still for cycles of time.

But the Chinese are not the only people who have turned their faces to the past. From the days when man first came blinking into the light of reason, he has contemplated the mystery of his origin and put his forbears high among his gods. 
There is reason to believe that the new social recognition of the child may be the dawning of another epoch, the beginning of a new philosophy, based on the truth that the generation in the course of formation is of much greater importance to the progress of the race than the generations which have passed away.

While child-welfare workers have followed their generous impulses rather than cold philosophy, those impulses are themselves an assertion of the elemental instincts for the perpetuation of the species.

There was opened yesterday in this city a child-welfare exhibit. It was not called by that name, but is, nevertheless, of prime importance to the children of this city.

The Philadelphia Milk Show at 809 Chestnut Street is a child-welfare exhibit. True, it deals only with one phase of the great subject. But just at this time that phase is one of the most important of all.

The city is entering upon the season when death stalks barefaced among the babies. Almost every infant born into the world is endowed with all the vitality it needs to carry it to vigorous maturity. Yet, as the flashing red light at the entrance to the Milk Show indicates, a baby under 1 year of age dies every ten seconds of the day and night.

One-half of these deaths are preventable within the established facts of human knowledge. The most deadly single cause-the one almost as fatal as all the other principal causes of death-is bad milk.

The Milk Show-our little child-welfare exhibition-aims to teach the people how to save the lives of their babies by assuring a supply of clean, wholesome milk. A bulletin issued by the Chicago department of health in connection with the child-welfare exhibit in that city gives the following cautions, which we think well to quote in this connection:

Many babies will die this summer for want of natural food (breast milk). More will die because of poisoned food (contaminated cow's milk). Many will be saved if given certified milk, the cost of a cigar and a glass of beer. Remember this at the funeral.

Germs which sicken and kill babies grow rapidly in milk unless it is kept very cold on ice. Every time the bottle is opened more germs may get in. To bead them off, take the cold bottle from the milkman's hands, wash and dry the outside of the bottle and put it on ice.

Wash your hands well before removing the stopper with a boiled fork. Do not breathe upon the milk. Stir or dip with a boiled spoon. Pour into boiled feeding bottle. Add boiled water or gruel which has been in a covered Mason jar on ice. Replace the stopper immediately and return to ice.

Protect baby against cats, dogs, flies, other children and your own carelessness.

Never save a part of unused food; never warm over. Make up each feeding fresh.

Never boil good, fresh certified milk for the baby. Never use any other kind. It is a crime to feed poor milk. If the food disagrees, weaken it. If baby sickens, stop feeding and call a doctor.

We know that the reference to this excerpt to certified milk will seem hopeless to many. The price is prohibitive to the struggling masses, where the infant mortality is greatest.

But the men who got up the Milk Show are the ones who prepared a monumental report showing how certified milk may be supplied to the entire city at a cost of only a ceut a quart more than what is now paid for an uncertain product. That is the meaning of the milk commission's report, of which the Show is a concrete exhibit. It is of vital-we use the word in its truest sense-it is of vital importance to the babies of this city.

\section{Editorial from the Philadelphia Public Ledger, May 21:}

\section{THE MILK SHOW}

It is a remarkable exposition of the science of pure milk production that is now in progress at 809 Chestnut Street, under the auspices of the Department of Public Health and Charities, the milk commission of the Pediatric Society, the veterinary school of the University, the Bureau of Municipal Research, and other co-operating agencies. The exhibits make as plain as possible the difference between good milk and bad, and the conditions that are responsible for the difference in quality are graphically illustrated by object lessons, whose meaning must be clear even to the illiterate observer.

Here, for instance, is the model of a cow barn of the old unsanitary type, in all particulars faithfully reproducing the filth and noisomeness; and next it is a stable on the new order, with the cattle well fed, sleek and clean. Here, again, is a complete pasteurizing apparatus in operation, showing the process of sterilization. There are cross-sections plainly revealing diseased conditions in cattle-conditions generally ignored by dairymen until a few years ago-the bacteriological tests are exhaustively illustrated. Not the least interesting exhibit is that of a row of bottles of several sizes, demonstrating the proportion of "raw" milk to that of the pasteurized and certified product. Photographs eloquently supplement the story told by the models and other object lessons, and finally there is a moving-picture 
exhibition which shows how bad milk made a baby sick, and as a result a sweeping reform in dairy management was effected by the remorseful parent. Finally, the lesson of the exhibits themselves is valuably enforced in a series of lectures by persons of wide knowledge and experience.

A visitor to the Milk Show cannot fail to be impressed by the disinterestedness of those who have arranged for the unique display. Like the City Planning Exhibition, it is an index of the broad and generous spirit of humanitarianism prevalent in this community. Those who have had any part in the laborious arrangement deserve the congratulations and the thanks of the entire community, and the results are sure to justify their praiseworthy undertaking.

Editorial in the Brockton, Mass., Times, May 22:

\section{A MILK SHOW}

In Philadelphia they are having a Milk Show, not to demonstrate the superiority of various breeds of cattle, but to educate the people in the proper care and use of milk, and the people of the city raised a fund of $\$ 8000$ to make this exposition possible. Demonstrations are given of methods of caring for milk from the time it is taken from the cow until it is fed to children and adults, and so valuable is the exposition considered by the school authorities that half-holidays are allowed the children, in order that they may attend. The head of the Philadelphia health department says of the Show that it will purchase the lives of thousands of babies and will also educate mothers, who will receive free lessons in the pasteurizing and modification of milk, and how to feed and care for children, so that not only the little ones of to-day, but those of future years will be safeguarded. This is the kind of a Show that is worth while, and Philadelphia sets an example that might well be followed in other communities, the milk problem, especially at this season, being much more than a question of price.

Editorial in the Yonkers, N. Y., Statesman, May 25:

\section{PROVIDE SAFE MILK}

The Milk Exhibition in Philadelphia gives a vivid example of the vital difference between new and old methods of dealing with social evils. For 50 years, since the exposures began of swill-fed cattle and pigs in New York, it has been known that the milk supply of a great city needed improved inspection and safeguards. But the usual way has been to reach this by exposure, by attack and by the endeavor to make evils visible.

This was the old method. The new method recognizes that nothing can be done without education and furnishing new opportunities to obtain the best. It proposes to reach conditions. It is comparatively useless to pass laws and ordinances in regard to milk, to inake exposures of poor milk, and to enact a better standard unless public opinion is educated to understand how milk, which is scarcely ever deleterious when it comes from the cow, is injured in milking, in pouring into cans, in carriage and in distribution; what harm these impurities do and the way to meet them.

The Milk Exhibition does this by an object lesson which will come home to everyone who sees it. Every day children die because, in spite of all pains, instruction and effort, they have been fed on milk which was in a condition certain to do harm.

Now honest dealers, taking this lesson to heart, provide the means by which mill can be furnished in exactly the right condition for children. Thus consumers find in milk safe nutriment for children during the hot days.

From the Boston, Mass., Evening Transcript, May 31:

\section{THE CLINIC}

On Saturday in Philadelphia there closed a week and a day of discussion of milk, bringing out to an extent not heretofore accomplished in this country a sober and sensible consideration of the subject of milk in its many phases, accompanying an exhibition the purpose and the effect of which were directly towards the education of the people with Unique Milk Show in thefence to this important food. Such an exhibition would do a world of Philadelphia good in Boston, for in the first place it would show how excellent the supply of milk is compared with the supplies of other large cities and, second, it would work changes in the present unsettled condition, fomented by the wild words and actions of the press, self-constituted guardians of the public health, politicians and even those in places where their public words should be conservative and not inflammatory. A calm setting forth of the facts, the presentation of truths, the meeting of farmer, middleman, contractor, scientist and legislator on the same ground, each ready to hear the other and give due credit to his opinions, has been a wonder in the clearing up of the situation so far as Philadelphia is concerned, while visitors from other cities have learned a good deal about the milk business. 
It was the coöperation of four institutions that brought together at Philadelphia a gathering including most of the authorities on milk in the country. It had its foundation in the report of the Milk Commission of that city, a body of experts appointed by Mayor Reyburn in October of last year. A report was presented to the mayor bearing the date of February, and a portion of the purpose of the meeting was to consider and discuss this report. For the occasion a Milk Show was organized under the auspices of the city Board of Health, the Milk Commission of the Philadelphia Pediatric Society, the veterinary department of the University of Pennsylvania and the Bureau of Municipal Research aided by other societies. Stores in the heart of the city, Chestnut street below Ninth, were secured for the exhibition, a hall was fitted up for the presentation of papers. Twenty-six sessions for the literary exercises were here held, with lectures in Yiddish, others especially for the employees in department stores, and with more than twoscore speakers in all. The names of these men who presented papers are known throughout the land where the question of milk is raised: Rosenau, Colt, Jacobi, Whitaker, Conn, Park, Schroeder, Francesco and Nichols, while health departments were represented in Dr. Neff of Philadelphia, Evans of Chicago, and Amyot of Toronto. There was discussed milk production, its relation to disease, the local milk commission and its uses, the care of milk in the home, its use in cooking, the supply for villages, its relation to human tuberculosis, and as a carrier of infection, its pasteurization, inspection, ice cream, deceptions in milk, journey from the cow to the consumer and the duty of the public. Besides these there were daily picture shows and demonstrations. All of this was free to the public of Philadelphia, and to what extent the public assisted may be known by the fact that the turnstiles for a single day registered fifteen thousand visitors. The arrangement of the Show was such that the people were kept moving in the same direction from entrance to exit, avoiding confusion. School children in processions were taken through the Show, catching items as they went for the education of the home. And the Milk Show was only one of four different sets of meetings.

At the Bellevue-Stratford there were two days devoted to the American Association of Medica Milk Commissions, of which Dr. Milton J. Rosenau of Boston is president. There was a conference of State and municipal health officers, to discuss the report of the commission, held also at the BellevueStratford, and for the last three days of the week the meetings of the Dairy Institute at the University of Pennsylvania, where there were twenty-five additional papers read and another Show, that of special dairy exhibits. 



\section{INDEX}





\section{INDEX}

Aввотт's Alderney Dairies, exhibit of, 8

Accounts, audit of, 27

- classification of, 27

Achor Chocolate Manufacturing Company, exhibit of, 81

Acknowledgments made for assistance and cooperation, 21

Admission, hours of, 1.4

- of children, 54

Advertising. (See also Publicity.)

Advertising cards printed in different languages, 30

_ _ sent to social organizations, 39 use of, by finance committee, 25

letter sent out by finance committee, 25

expenditures for, 27

methods employed, 28, 29

Agencies, coöperating, names of, 14

American Association for the Study and Prevention of Infant Mortality, exhibit of, 53

_ of Medical Milk Commissions, The, annual session of, 13

of Medical Milk Commissions, The, exhibit of, 78

Announcement folder, preliminary. (See Preliminary announcement folder.)

- slips sent to dairy farmers, 19

- publicity through, 29

Application blank for commercial exhibits, 34, 106,107

Armstrong Association, coöperation by, 31

Arrangements in general, committee on. (See under Committees.)

Articles remaining after Show, disposition of, 21

Attendance, figures of, 45,46

Attendants required, 23

Audit of accounts, 27

BABY day or week, publicity through a special, 29 Bacteriological Laboratory of Department of Public Health and Charities, exhibit by, 53, 54 Bills, procedure in payment of, 19-20

- - required approval of, 20

—_ delivered to executive secretary, 20

Building, expenditures on preparation of, 27

Bureau of Municipal Research, accounts audited by members of, 27

-

Buttons, celluloid, distributed to children to advertise Show, 32

CALoris Manufacturing Company, exhibit of, 81 Caps. (See Milk bottle caps.)
Car Advertising Company, display of advertising cards by, 31

Certified milk, exhibit of, 56

- Producers' Association of America, annual session of, 13

Chemical Laboratory of Department of Public Health and Charities, exhibit by, 53, 54

Child hygiene, exhibit on, by Department of

Public Ilealth and Charities, 66-76

Children's Bureau, coöperation of, 31

Churches, publicity through, 29

City Controller, audit of accounts by chief accountant in office of, 27

Councils, contribution by, 27

Cleaning of show-rooms, arrangements for, 22

- supervision of, daily, 23

Collection of milk in and around Philadelphia, special exhibit showing, 56

Commercial exhibits, kinds of exhibits included with, 18

_ charge for floor space, 34

- description of, 80 106,107

\section{Committees:}

Arrangements in general, members and duties of, 21-23

Conference of health officers, members and duties of, 35

_- joint meetings held with committee on lectures and demonstrations, 35

Dairy institutions and milk contests, members and duties of, 37,38

joint meetings held with committees on lectures and demonstrations and conference of health officers, 35, 38

Education, members and duties of, 36,37

joint meetings held with committees on publicity and social organizations, 28, 39

Executive, organization of, 13

officers of, 17

- members and duties of, 17-21

Finance, members and duties of, 24-27

Lectures and demonstrations, members and duties of, 35

joint meetings held with committees on dairy institutions and milk contests and conference of health officers, 35

Patronesses and aides, members and duties of, 40,41

Procuring exhibits, members and duties of, $32-34$

Publicity, members and duties of, 28-32 
Committees:

Publicity, joint meetings held with committee on social organizations, 39

Social organizations, members and duties of, 39,40

joint meetings held with committees on publicity and education, 28,39

Conference of health officers, committee on. (See under Committees.)

- - of State and Municipal Health Officers, description of sessions of, 14, 46

Contract for commercial exhibits, 34, 106, 107

Contributions, solicitation of, 25

Contributors, list of, 26

Correspondence, care of, by executive secretary, 21

Count of visitors, how made, 54

Cream contests. (See under Milk and cream contests.)

Creamery Package Company, exhibit of, 81

Crown Cork and Seal Company, The, exhibit of, 81

Cups, sanitary paper drinking, used exclusively, 22

Current expenses, method of paying, 19, 20

DAIRY barns, models of, exhibit by Pennsylvania State Live Stock Sanitary Board, 57

Dairy Division, Bureau of Animal Industry, United States Department of Agriculture, exhibit of, 78

- - Bureau of Animal Industry, milk and cream contests under supervision of, 38,48

Institute, description of, 13, 14, 47

institutions and milk contests, committee on. (See under Committees.)

Specialty Company, exhibit of, 81

- stables, description of reproductions of good and bad, 47

Dairymen's Supply Company, exhibit of, 81

Day Nurseries, coöperation by Association of Philadelphia, 40

Dealers, letter to, requesting coöperation in advertising, 31

Decorating of show-rooms and exterior of buildings, 22

Decorations, expenditures on, 27

Deficit, to be paid by guarantors, 25,27

Demonstrations. (See under Committee on lectures and demonstrations and in descriptions of various exhibits.)

Demonstrators, duties of, 35

- provision of, 35

— payment of, 35

- supervision over, 23

- to explain exhibits, 14

Department of Public Health and Charities. (See under Health.)

- of Public Safety. (See under Safety.)

Description of commercial exhibits, 80, 81

Conference of State and Municipal Health Officers, 46

Dairy Institute, 47

educational exhibits, 53,80

milk and cream contests, 48
Design, pictorial, for advertising matter, 29

Doering, Paul, exhibit of, 80

Drinking fountains provided in exhibition rooms, 22

Education, Board of Public, coöperation of, 30, 31 arrangement made for bringing school children to Show, 36, 37

committee on. (See under Committees.)

Educational benefit to be derived from a Milk Show, 13, 14

__ exhibits, kind of exhibits to be classed as, 18 - description of, 53

leaflets, cost of, 36

disposal of those remaining after the Show, 21

distribution by committee on patronesses and aides during Show, 40

methods of distribution, $36,37,54$

ordered during Show from printers as required, 36 preparation of, 36

publicity by means of, 29

quantity required, 36

reproduction of, 92-105

Electric connections required, 22, 34

fans provided, 22

lights installed, 22

sign on front of building, 22

signs on City Hall, 29

Electrical equipment, expenditures on, 27

Entertainment of Delegates to Conference of State and Municipal Health Officers, 46

Entry blanks for milk and cream contests, reproduction of, 108, 109

- preparation of, 21

mailed to all producers for this market, 38

Essex County, New Jersey, exhibit of Medical Milk Commission of, 77

Executive Committee. (See under Committees.) - office in Milk Show building, 78

Executive secretary, acknowledgments made by, 21

detailed work performed in office of, 19,21

handling of vouchers by, 19,20

office started, 17,18

payments from petty cash fund by, 19,20

petty cash fund established, 20

_- petty cash fund provided for secretary of committee on arrangements in gen-

eral, 20
procedure in payment of pay-rolls by, 20

publication of comprehensive report by, 20

replenishment of petty cash fund, $\mathbf{2 0}$ supervision of work of, 18

Exhibition rooms, selection of suitable, 21, 22

Exhibits, character of, 18, 34

- classification of, 33 date of receipt, installation, and removal of, 34

delivery to exhibition rooms of shipments of, 32 
Exhibits, expenditures on installation of, 27 installation of, 23

method of procuring, 32

- procedure followed on receipt of, 23

removal of, 23

- return of, 32

- transfer from railroad stations to exhibition rooms, 34

Expenditures, statement of, 27

Expenses, current, method of paying, 19, 20

Expenses, estimating, 19

- of speakers, 35

- schedule of estimated, 24

Expressage, expenditures for, 27

Finance Committee. (See under Committees.)

- method of, 13, 19, 20, 24, 25

Financial statement, 27

Firemen detailed to show-rooms, 23

Floor plans, prepared by architects, 22

- sections or booths numbered consecutively, 23, 53

space, estimate of amount required, 34 sale of, 25,27

- of lecture hall, 22

of exhibition rooms, 22

Ford, The J. B., Company, exhibit of, 81

Foreign newspapers (those outside city) furnished copy, 39

Foreign population advised of Show, 39

Freight, expenditures on, 27

Function of a Milk Show, 13

Furniture required for lecture hall and show-rooms, 22,34

GAs connections, required, 34

- supplied, 22

Guarantors secured to underwrite expenses, 24, 25

Guards, provision of necessary, 23

HAND-BILLs, publicity through, 29

Hand-book. (See Educational leaflets.)

Hand-book to exhibition, 29

Hauling, expenditures for, 27

Health and Charities, Department of Public, first meeting to discuss Milk Show plan called by Director of, 13

Department of Public, contribution from City Councils secured through Director of, 25

Department of Public, exhibit on child hygiene by, 66-76

Department of Public. (See also Bacteriological and Chemical Laboratories.)

Health officers, programs mailed to, 35

Home and School League, coöperation by, 31

Honoraria, expenditures for, 27

Hours of admittance to Milk Show, 14, 4.5

of sessions of Dairy Institute, 47

House fly campaign, help from Milk Show organization, 19

ICE-CREAM, special exhibit showing modern method of making, 64
Ice-cream, special exhibit of Pennsylvania State Live Stock Sanitary Board showing results of bacteriological examinations of, 64

Independent Milk Dealers, exhibit of, 80

Inspection of buildings prior to Show by city fire and building inspectors, 22

Insurance for show-rooms and exhibits, 19

- accident, 22

- fire, 22

- general liability, 22 expenditures for, 27

Invitations issued, to meeting in Mayor's office, 18 - to private view, 45

Kelux, William, exhibit of, 80

Kennedy, S. R. and S. W., and Company, exhibit of, 81

Kensington Engine Works Company, exhibit of, 81

Laboratories. (See under Bacteriological and Chemical Laboratories.)

Laborers, supervision over, 23

Leaflets, educational. (See under Educational.)

Lecture hall, equipment of, 22

- floor space of, 22

- rental of, 22

Lectures and demonstrations, committee on. (See under Committees.)

— public, given daily, 13, 14, 46

Legend "To Enlighten-Not To Frighten," use of, 19

Letter sent, asking for financial support, 25

- to dairy farmers with entry blanks for milk contests, 38

——_ to milk dealers requesting coöperation in advertising, 31

—— to prospective exhibitors, 34

—— to social organizations asking coöperation, 39

- — to hospitals asking coöperation, 40

Light, sale of, to commercial exhibitors, 27

Lighting equipment, expenditures on, 27

MAIL, distribution of daily, 21

Maryland State Board of Health, exhibit of, 79

Massachusetts Milk Consumer's Association, exhibit of, 59

Maynard, Lee H. P., exhibit of, 80

Mayor, public meeting in office of, 18

Mechanical Refrigerating Machine Company, exhibit of, 80

Meeting, initial, Milk Show movement started, 13

Meetings of committees, members notified by executive secretary, 21

Milk and cream contests, arrangements perfected for, 38

\begin{tabular}{l} 
awards in, 48,49 \\
description of, 48 \\
eligibility rules of, 48 \\
\hline \\
entries in, 48
\end{tabular} 
Milk as a food, special exhibit showing uses of, 62 bottle caps, special, description of, 32 caps, special, publicity through use of, 29

- caps, special, sale of, 27

collection of, in and around Philadelphia, special exhibit showing, 56

- Commission, appointed, 13

- - of Philadelphia Pediatric Society, exhibit of, 56
report submitted, 13

- in the home, special exhibit on care of, 61 forms and instruments used, 76

- problem pertinent, 13

- Show proposed, 13

Minutes of executive committee, 18

Moving pictures, expenditures on, 27

- used to help educate, 14

- given daily, 46

NEIGHBORHOOD workers informed about Show, 39 Newark, New Jersey, Babies' Hospital, exhibit of, 77

Newspapers, amount of publicity, 28

- articles preserved, 14

- city editors on committee on publicity, 28

- copy prepared daily, 18, 28

- publicity through, 29

support enlisted, 28

New York City Department of Health, exhibit of,

- Milk Committee, exhibit of, 59

Notices sent to dairy farmers, 19

OFFICE at show-rooms, equipment of, 22

Organization of various committees, 17, 41

Pasteurization of milk, special exhibit showing most scientific methods, 65

Pathological exhibit by Veterinary Department, University of Pennsylvania and Pennsylvania State Live Stock Sanitary Board, 78

Patronesses and aides, committee on. (See under Committees.)

- list printed, 36

Pay-day, special, possible publicity through, 29

Pay-rolls, payment of, 20

Pediatric Society, Philadelphia. (See Milk Commission.)

Pennsylvania Railroad Company, display of advertising cards by, 31

- - exhibit of, 59

Society for Prevention of Tuberculosis, exhibit of, 57

- State Live Stock Sanitary Board, exhibit of, $57,64,78$

_- University of. (See under Veterinary department and also Pathological exhibit.)

Petty cash fund, how administered, 19, 20

- fund, replenishment of, 20

- fund, of secretary of committee on arrangements in general, 20
Petty cash receipt, form of, 20

Philadelphia and Reading Railroad Company, display of advertising cards by, 31

— Rapid Transit Company, helped with advertising, 31

- Rapid Transit Company, furnished free transportation to school children, 37

Phillips, Charles H., Company, exhibit of, 81

Pictorial design for advertising matter, 29

Plans, floor. (See under Floor.)

Plumbing equipment, expenditures on, 27

Policemen detailed to show-rooms, 23

Postage, expenditures for, 27

Posters, large bill-board, cost prohibitive, 29, 30

Power, sale of, to commercial exhibitors, 27

Preliminary announcement folder, content, 13

-1 folder, copies sent to social organizations, 39

folder, distribution of, $29,30,38,39$

folder, use of, by finance committee, 25

Press comments, reprints of a few, 110-115

Printing, expenditures for, 27

Private view of exhibits, 45

Privileges allowed commercial exhibitors, 34

Prize cups awarded in milk contests, exhibit of, 77

Procuring exhibits, committee on. (See under Committees.)

Programs, legend adopted for, 19

methods of distribution of, 54

- of Conference of State and Municipal Health Officers, reproduction of, 87,88

—- of Dairy Institute, arranged by correspondence, 38

of Dairy Institute, reprint of, 89-91

of Milk Show, preparation of, 35

of Milk Show, reprint of, 85, 86

- proposition of issuing same on commercial basis, 19

Public Education, Board of. (See under Education.)

— Health and Charities, Department of. (See under Health.)

Publicity agent, duties of, 28

- $\longrightarrow$ employed, 28

- methods of work employed by, 28

__ committee on. (See under Committees.)

- methods adopted, 28, 29

Purposes of Milk Show, 13, 18

Raruroad stations, display of advertising cards in, 29, 31

Receipts, how secured, 25

statement of, 27

Refreshment counter, operation of, 55

Rent, expenditures for, 27

Report, inventories of exhibits for, 20

photographs taken for, 20

Restoration of buildings after Show, 23

Root Dairy Supply Company, exhibit of, 81

Russell Sage Foundation, wall placard furnished by, 37

SAFETY, Department of Public, provided police and fire protection during Show, 23 
Salaries paid from petty cash fund, 20

Salary expenditures, 27

Sale of certified milk, 55

of milk in and around Philadelphia, special exhibit showing conditions of, 56

of samples by commercial exhibitors prohibited, 34

Sanitary paper drinking cups used, 16

School children at Show, manner of handling, 37 children's day, special, publicity through, 29

Schools, publicity through, 29, 30

Schutte and Koerting, exhibit of, 80

Scope of a Milk Show, 13

Secretary of committee on arrangements in general, petty cash fund of, 20

Settlements, coöperation by, 39

Shapiro, Samuel, exhibit of, 81

Sharpless, P. E., Company, exhibit of, 81

Shipping instructions, requirements concerning provision of, 23,34

- (See also Application blank and contract for commercial exhibits, 106, 107.)

Show-rooms, selection of suitable, 21,22 rental of, 22

floor space of, 22

Signs, expenditures on, 27

on front of exhibition building, 19, 45

required within show-rooms, 34

supplied within show-rooms, 22, 23

Single Service Package Corporation of America, exhibit of, 81

Social agencies, publicity through, 29

clubs informed of Show, 40

organizations, committee on. (See under Committees.)

Space. (See under Floor space.)

Stables. (See Dairy barns and Dairy stables.)

Stereopticon, expenditures on, 27

Stores, display of cards in show windows of, 29, 31

Street-cars, advertising cards displayed within, 29,31

- advertising signs attached to fenders, 29, 31 Sub-committees, organization of, 17
Sub-committees, reports from, 18

Subscriptions, solicitation of, 25

Subway stations, display of advertising cards in, 29, 31

Supplee Alderney Dairies, The, exhibit of, 81

Telephones, public, supplied in exhibition rooms, 22

Trade organizations informed concerning Show, 40

Transportation of milk in and around Philadelphia, special exhibit showing, 56

Treasurer, closing accounts with, 26, 27

—_ financial statement of, 27

- handling of vouchers by, 19, 20

- payment of bills by, 19,20

- payments advanced on pay-rolls by, 20

— replenishment of petty cash fund of executive secretary by, 20

Underwriters Company, The, exhibit of, 81

United States Department of Agriculture, Bureau of Animal Industry, Dairy Division, exhibit of, 78

milk and cream contests under supervision of, 38,48

Veterinary Department, University of Pennsylvania, pathological exhibit of, 78

University of Pennsylvania, meeting place of Dairy Institute, 38, 47

Vice-chairman, vouchers countersigned by, 19

Visitors, method of handling, 54

Vouchers, form and use of, 19, 20

WATER connections, required, 34

- supplied, 22

West Disinfecting Company, exhibit of, 81

Woolman, Edward, exhibit of, 81 
(3) โ2: :

LBMr 12 


\section{THE REPORT OF THE \\ P H I L A D E L P H I A \\ M I L K SHOW}

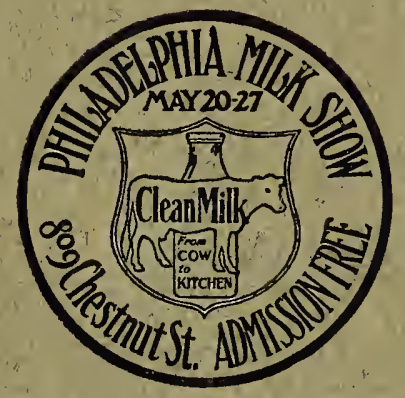

TO ENLIGHTEN

NOT TO FRIGHTEN

1911 


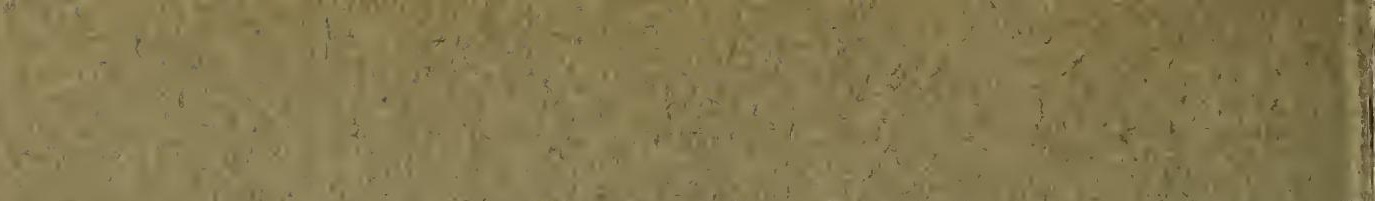

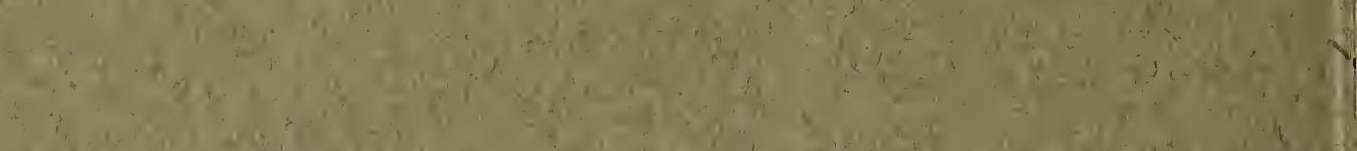

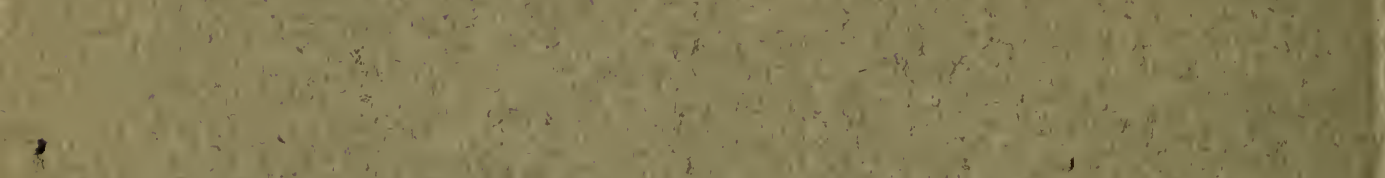

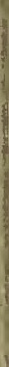

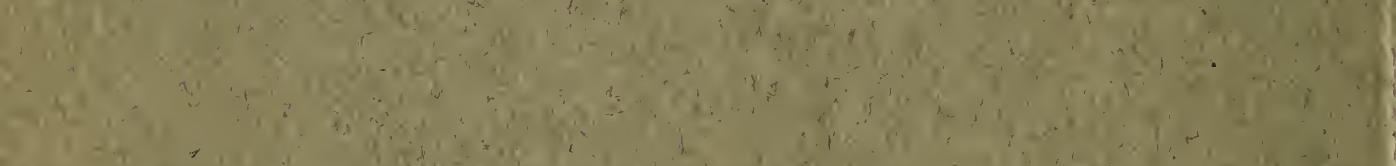

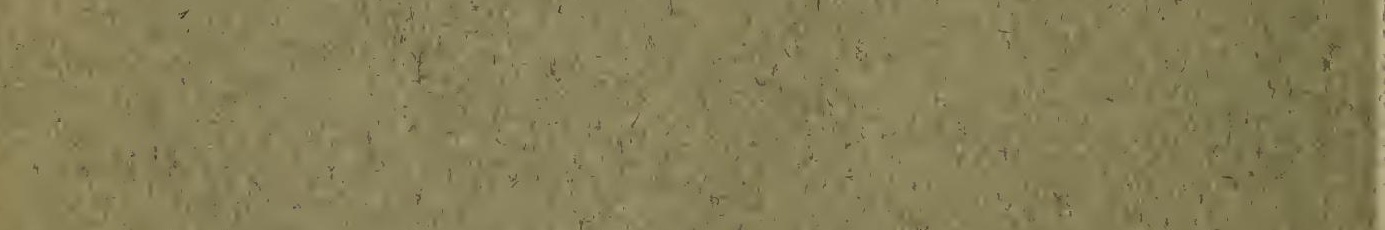

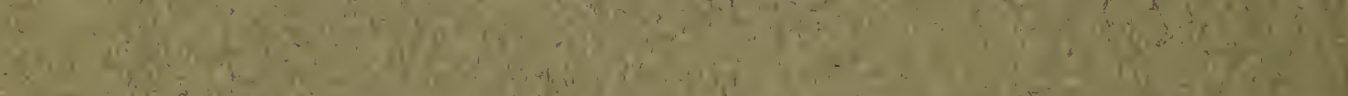

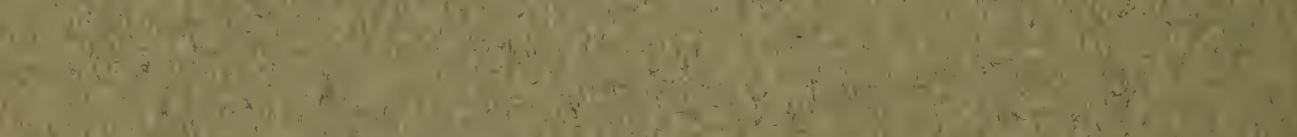

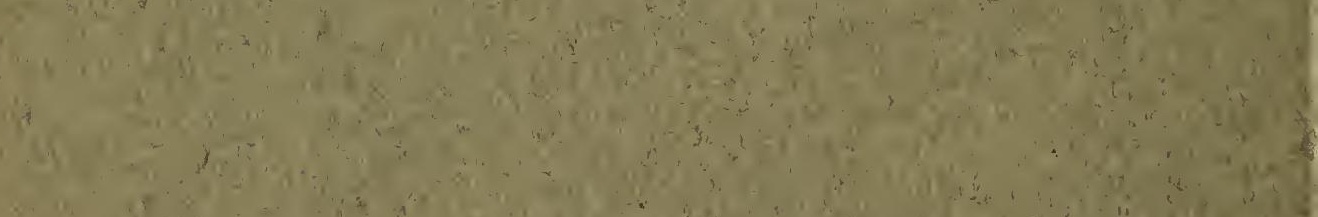
(2) 

. 


LIBRARY OF CONGRESS

|||||||||||||||||||||||||||||||||||||||||||||||||

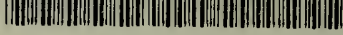

0000896081 1. 